\title{
Stratigraphic development and petroleum prospectivity of northern Zealandia
}

\author{
By \\ Zelia Da Gloria Dos Santos
}

A thesis submitted to Victoria University of Wellington

June 2020

In partial fulfilment of requirements for the degree of Master of Science in Petroleum Geoscience

School of Geography, Environment and Earth Sciences

Victoria University of Wellington 



\section{Abstract}

Northern Zealandia lies between Australia, New Zealandia, and New Caledonia. It has an area of 3,000,000 $\mathrm{km}^{2}$ and is made up of bathymetric rises and troughs with typical water depths of 1000 to $4000 \mathrm{~m}$. I use 39,309 line $\mathrm{km}$ of seismic-reflection profiles tied to recent International Ocean Discovery Program (IODP) drilling and three boreholes near the coast of New Zealand to investigate stratigraphic architecture and assess the petroleum prospectivity of northern Zealandia.

Sparse sampling requires that stratigraphic and petroleum prospectivity inferences are drawn from better-known basins in New Zealand, Australia, New Caledonia, TimorLeste and Papua New Guinea. Five existing seismic-stratigraphic units are reviewed. Zealandia Seismic Unit U3 is sampled near New Zealand and may contain Jurassic Muhiriku Group coals. Elsewhere, Seismic Unit 3 may have oil-prone equivalents of the Jurassic Walloon Coal Measure in eastern Australia; or may contain Triassic-Jurassic marine source rocks, as found in offshore Bonaparte Basin, onshore Timor-Leste, and the Papuan Basin in Papua New Guinea. Seismic Unit U2b (Mid-Cretaceous) is syn-rift and may contain coal measures, as found in Taranaki-Aotea Basin and New Caledonia. Seismic Unit U2a (Late Cretaceous to Eocene) contains coaly source rocks in the southeastern part of the study area, and may also contain marine equivalent carbonaceous mudstone, as found at Site IODP U1509. Unit U2a is transgressive, with coaly source rocks and reservoir sandstones near its base, and clay, marl and chalk above that provides a regional seal. Seismic Unit U1b (Eocene-Oligocene) is mass-transport complexes and basin floor fans related to a brief phase of convergent deformation that created folds in the southern part of the study area and regionally uplifted ridges to create new sediment source areas. Basin floor fans may contain reservoir rock and Eocene folding created structural traps. Seismic Unit U1a is Oligocene and Neogene chalk, calcareous ooze, and marl that represents overburden. Mass accumulation rates (MAR) and climatic temperatures were high in the late Miocene and early Pliocene, resulting in peak thermal maturity and hydrocarbon expulsion at $\sim 3 \mathrm{Ma}$.

Approximately one-fifth of the region has adequate source rock maturity for petroleum expulsion at the base of Seismic Unit U2: Fairway Basin (FWAY), southern New Caledonia Trough (NCTS) and Reinga Basin (REIN). Plays may exist in either Seismic Unit U3 or U2, with many plausible reservoir-seal combinations, and several possible trapping mechanisms: unconformities, normal faults, folds, or stratigraphic pinch-out. The rest of the region could be prospective, but requires a source rock to exist within Seismic Unit U3, which is mostly unsampled and remains poorly understood. 


\section{Acknowledgements}

The extensive scope of the work undertaken in this study, much of which requiring long period of time sitting in front of a computer, would not have been possible without the assistance of a multitude of people. Hence, I have many people to thank.

First and foremost, I am heartily thankful to God Almighty and his Son Jesus Christ for leading me through all the difficulties. I have experienced your guidance day by day.

I would like to express my special appreciation and thanks to my supervisor, Prof. Rupert Sutherland, for his valuable and constructive suggestions during the planning and development of this research. I am thankful for the opportunity you gave me to do this research. Your endless moral support throughout the year and for providing critical feedback on earlier drafts of the thesis. Thank you for being patient with my limited English writing skills, and I learnt a lot from your red pens. Your door was always open and discussed through email and zoom (during COVID-19 lockdown). You were always willing to share your encyclopedic geological knowledge, unraveling geological problems, and passing on the importance of a diligent, repeatable scientific methodology. I am profoundly indebted to you for all the support and assistance you have given me throughout the completion of this research; without you, this achievement would not have been possible.

Special thank goes to New Zealand Government through the Ministry of Foreign Affairs and Trade (MFAT). I am very grateful for the financial support that I received through this New Zealand scholarship award.

I would also like to acknowledge and thank Victoria International for all the support, and special thanks is given to our beloved ISOs, Clemmie Newton, Ryan Stuart, and Stefanie Fischer for all the support, encouragement, and guidance during my study. I also thank Vivian for her assistance in terms of financial affairs.

Thank you, Wanda Stratford, for providing me twt-depth relationships. Thanks for your time and discussion through email.

Thank you, Aleksandr Beliaev, for making your time available to check the SeisWare license and helping me when I had trouble with my desktop.

Thank you, Callum Skinner, for your available time helping me on SeisWare. 
To Eujay McCartain, thank you for your support and recommendation particularly to come to Victoria University of Wellington to study in this area of research.

I owe my loving thanks to my family. They are my moral and spiritual guides, and their encouragement and full support. Thanks, Sifa and Franlia Fernandes, for all support, love and being always there for me.

Lastly, thanks to friends and colleagues (in Timor-Leste and Wellington) for their support, caring, thoughts and encouragement so that I can make my way to the end of my study journey. 


\section{Contents}

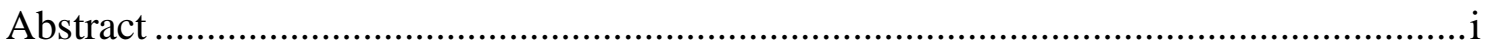

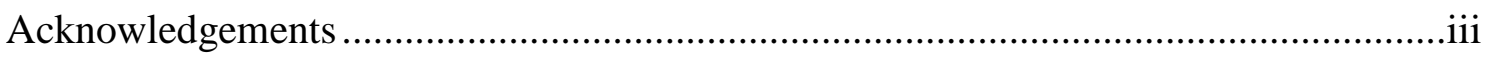

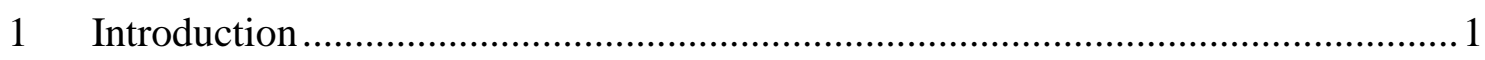

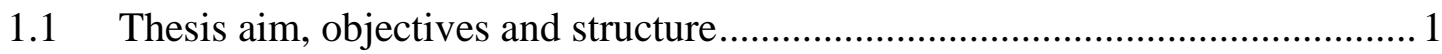

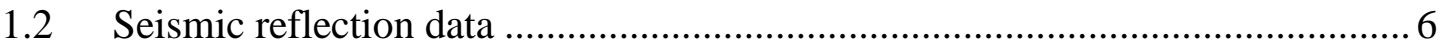

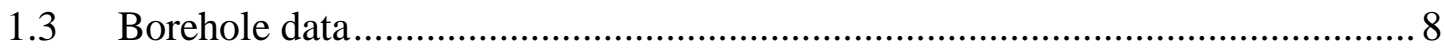

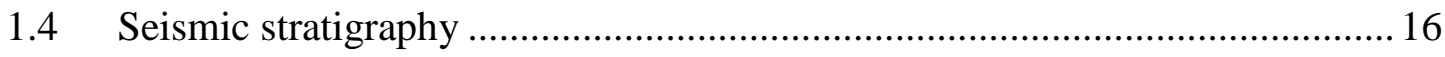

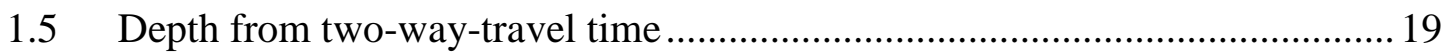

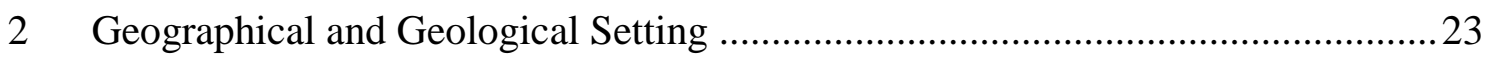

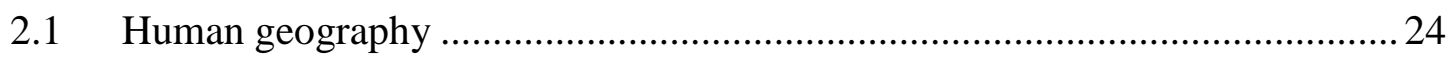

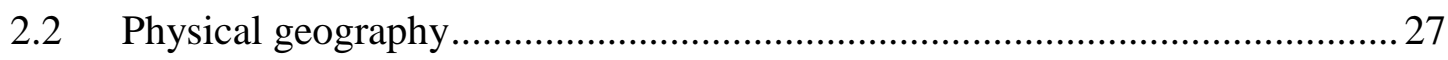

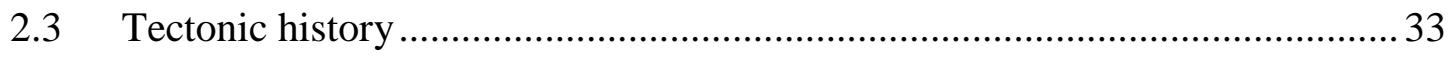

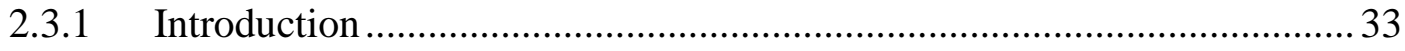

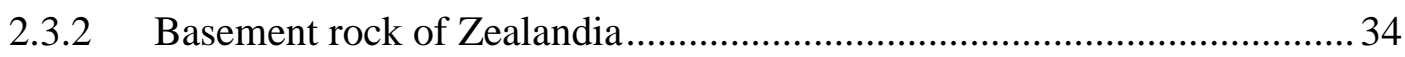

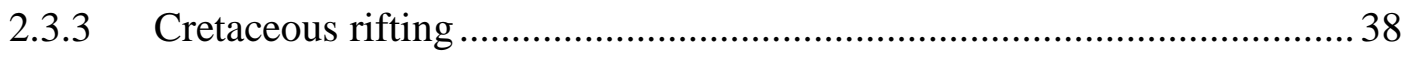

2.3.4 Cretaceous and Paleogene passive margin............................................ 38

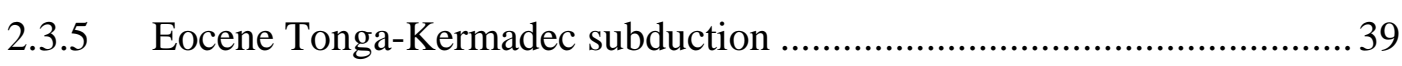

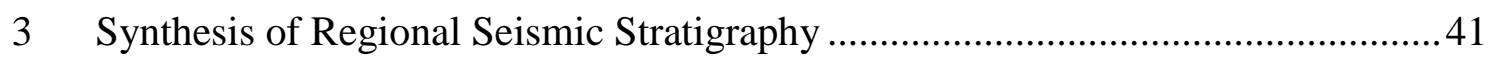

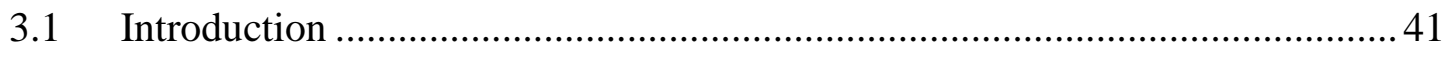

3.2 Southern Lord Howe Rise (LHRS) …........................................................ 43

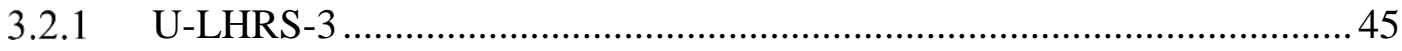

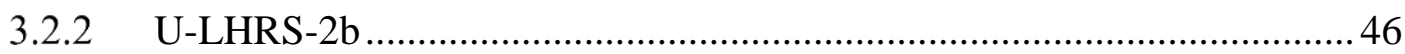

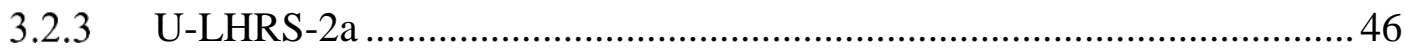

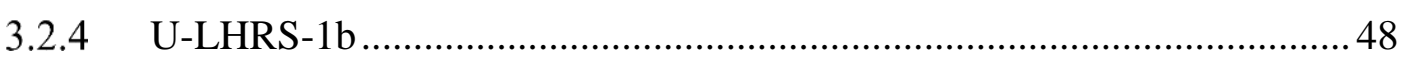

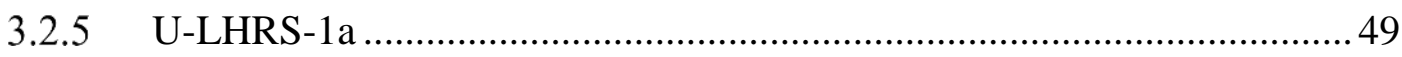

3.3 Northern Lord Howe Rise (LHRN) .......................................................... 50

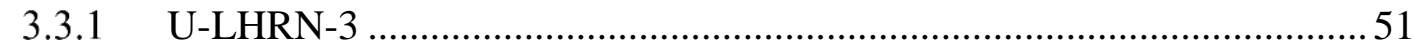

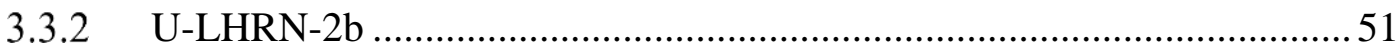

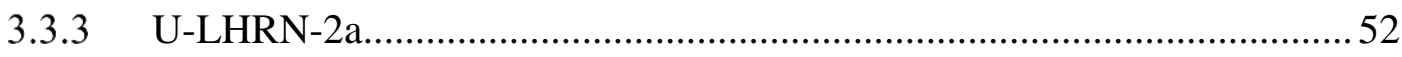

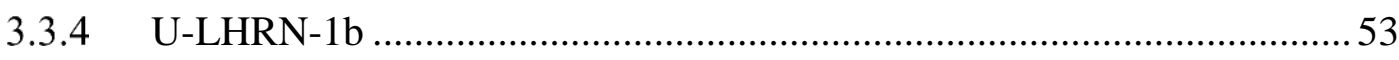

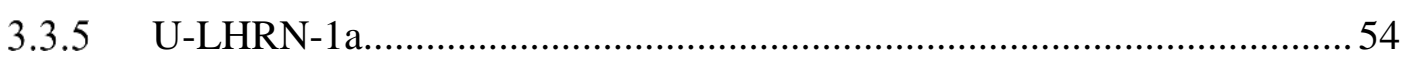

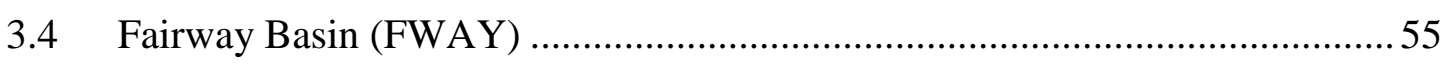




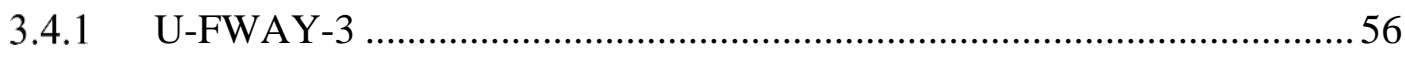

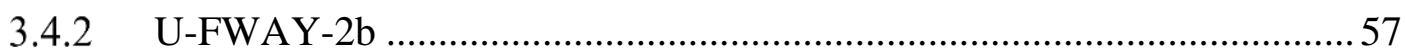

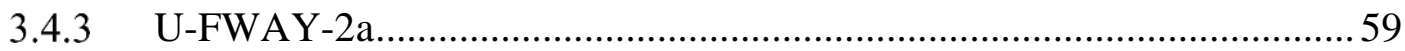

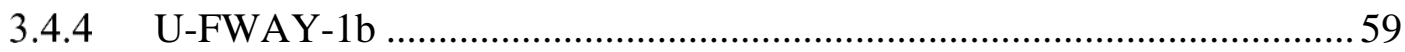

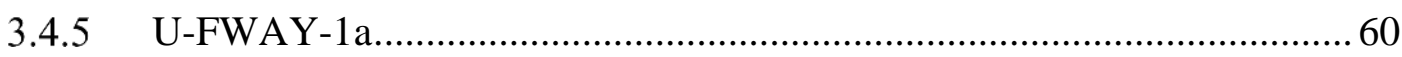

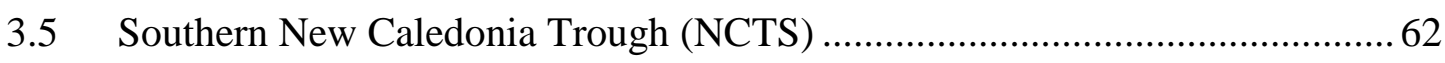

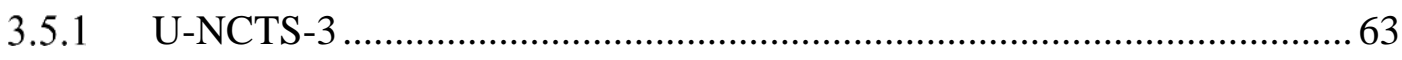

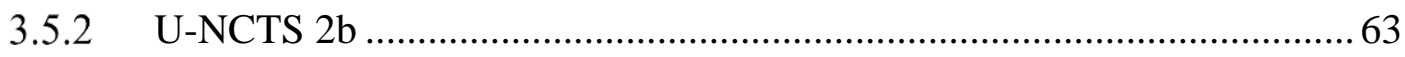

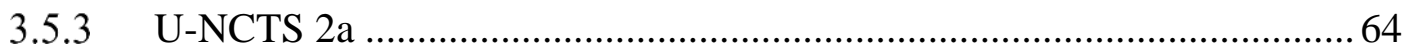

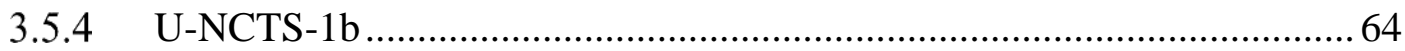

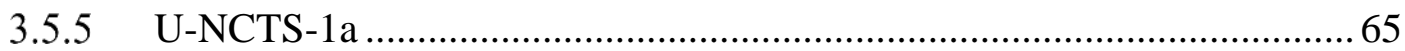

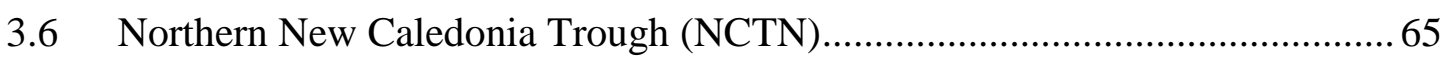

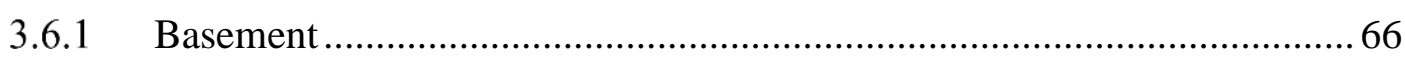

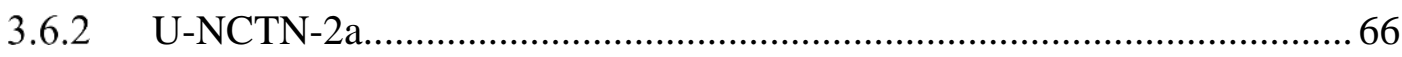

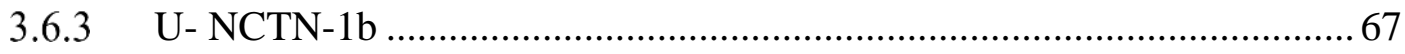

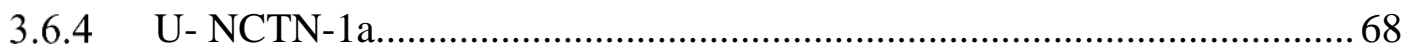

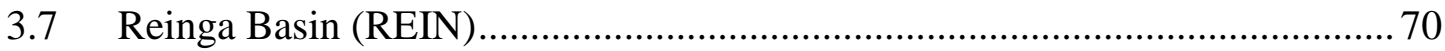

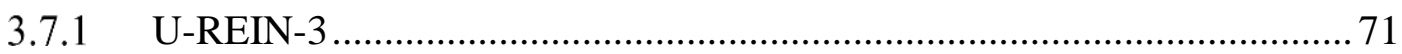

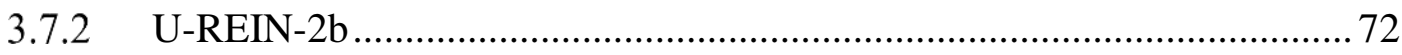

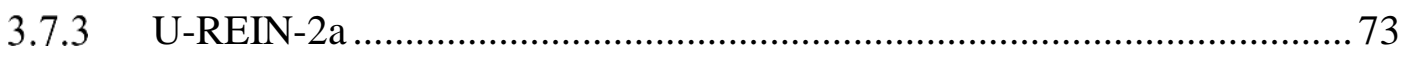

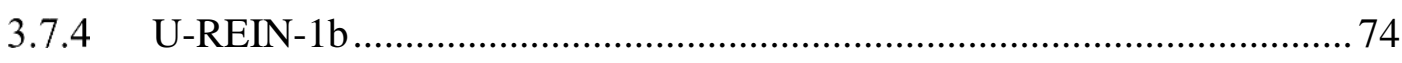

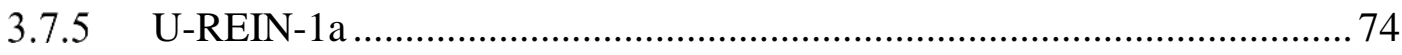

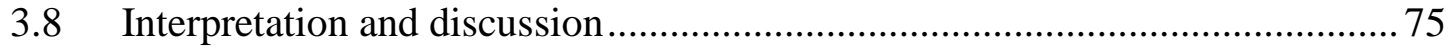

3.8.1 Geology relationship across northern Zealandia.................................... 75

3.8.2 Seismic Unit U3-U2b stratigraphic relationships ................................. 80

3.8.3 Seismic Unit U2a-U1b stratigraphic relationships................................ 81

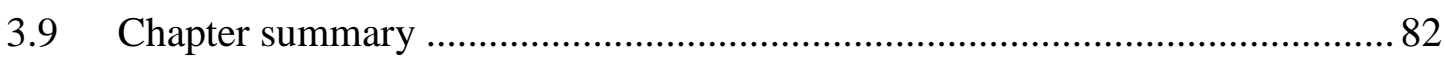

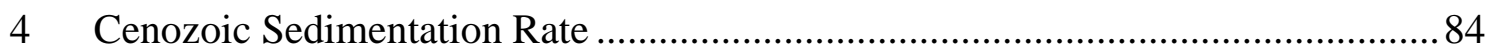

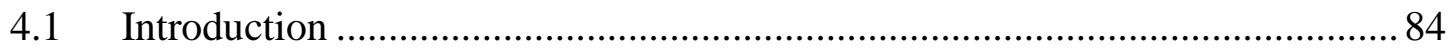

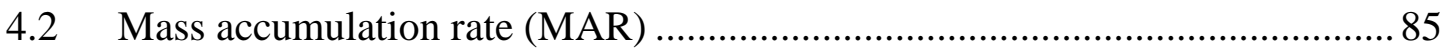

4.3 Northern Lord Howe Rise (LHRN) ............................................................ 88

4.3.1 Results of seismic stratigraphy interpretation .................................... 88

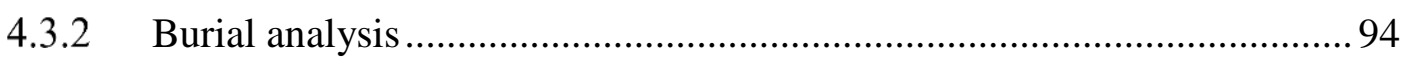

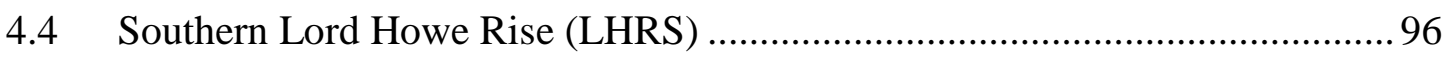

4.4.1 Seismic interpretation for borehole IODP U1510 ................................ 96 
4.4.2 Seismic interpretation for boreholes DSDP 207 and 592 ..................... 100

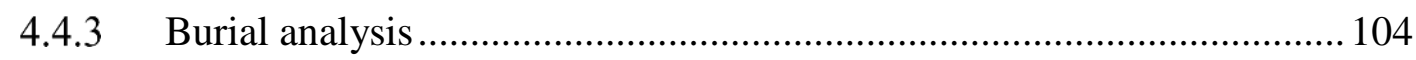

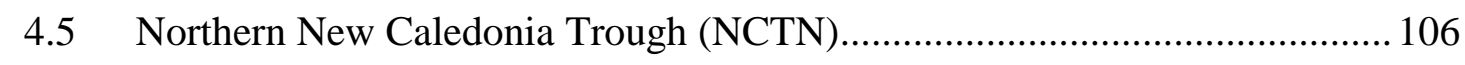

4.5.1 Result of seismic stratigraphy interpretation......................................... 107

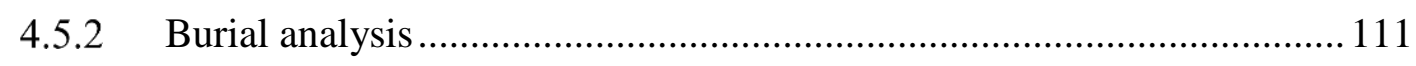

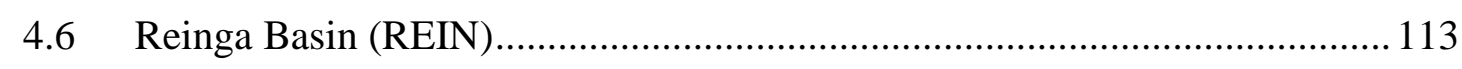

4.6.1 Result of seismic stratigraphy interpretation...................................... 113

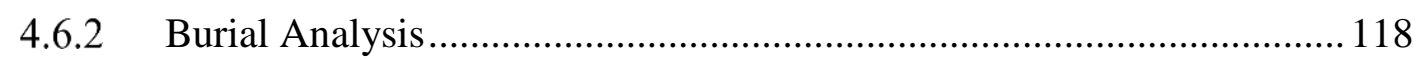

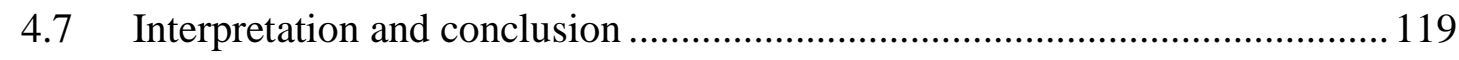

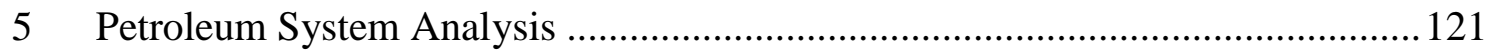

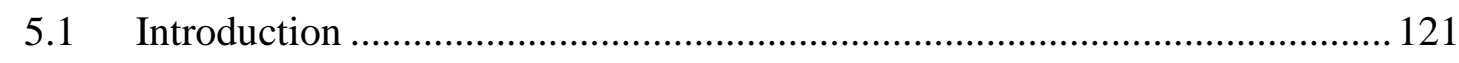

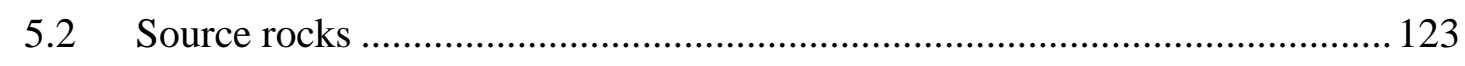

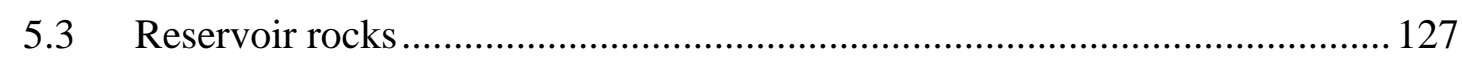

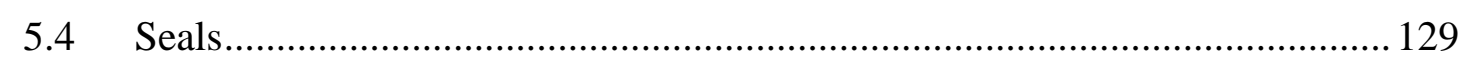

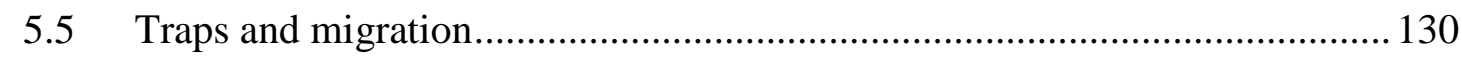

5.6 Overburden deposition and source rock maturity ….................................... 131

5.7 Distribution of petroleum system components ............................................ 133

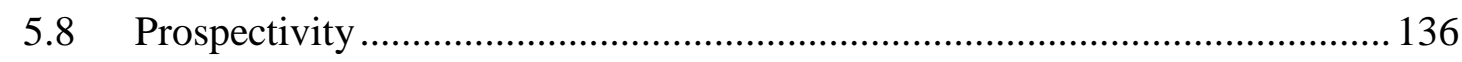

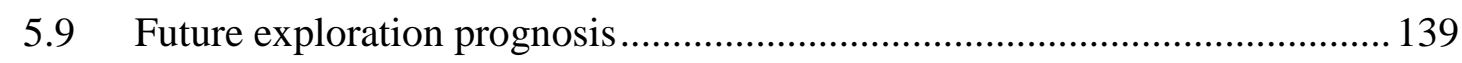

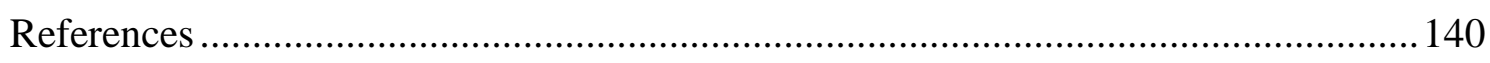

Appendix A: New Zealand geological timescale ................................................... 155 


\section{List of Figures}

Figure 1.1. Northern Zealandia bathymetric map showing the location and distribution of seismic data. .4

Figure 1.2. Bathymetric map of northern Zealandia showing the location and distribution

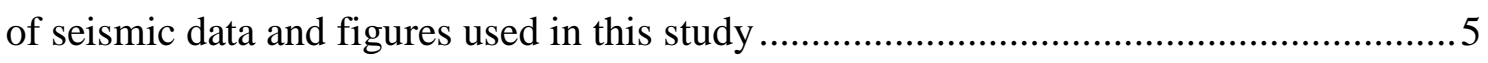

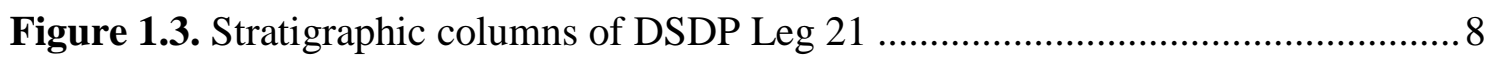

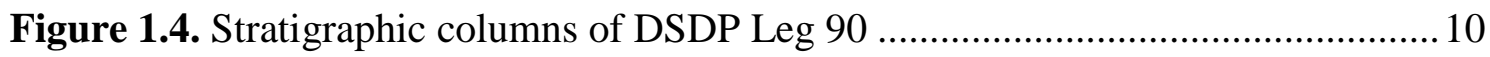

Figure 1.5. Stratigraphy columns showing main lithology at the IODP boreholes

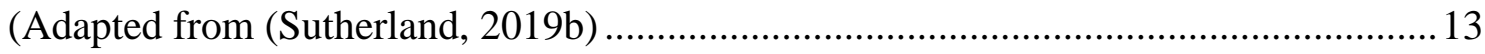

Figure 1.6. Age-depth models for each IODP sites (Sutherland, 2019b)...................... 14

Figure 1.7. Stratigraphy relationships adapted from Catuneanu et al., (2009) and Mitchum et al (1977) used to map seismic stratigraphy in the study area ..................... 17

Figure 1.8. Reflection configurations used for seismic facies interpretation in the study area (Mitchum Jr et al., 1977b, Mitchum Jr et al., 1977a) ............................................ 18

Figure 1.9. Physical property data DSDP 208 (north of Lord Howe Rise) from Stratford et al. (2018)

Figure 1.10. Seismic line Ga-302-09 at Site DSDP 208 …........................................ 20

Figure 1.11. Seismic line TAN1409-NCTN-11 at CDP 4020 recorded at Site U1507. 21

Figure 2.1. Bathymetry map showing the southwest Pacific region with major cities and

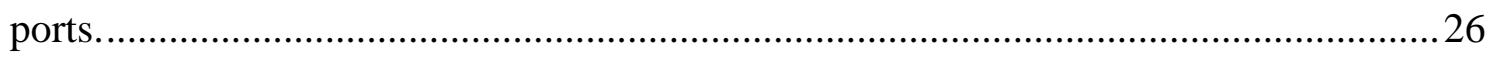

Figure 2.2. Global setting illustrates the major ocean currents that occurred through northern Zealandia 28

Figure 2.3. Antarctic Circumpolar Current (ACC) fronts from south to north.... 28

Figure 2.4. Bathymetry of southwest Pacific showing depth shallower than $6000 \mathrm{~m}$ and the main currents

Figure 2.5. Four phases of tectonic evolution of the southwest Pacific (Bache et al.,

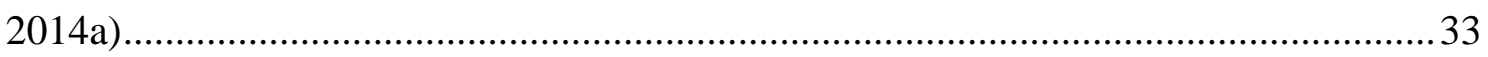

Figure 2.6. Tectonic reconstruction of the southwest Pacific region ............................ 36

Figure 2.7. Mesozoic - Cenozoic break-up of the eastern Gondwana margin from (Higgins et al., 2014).

Figure 3.1 Seabed ribbon of the region showing where key horizons were identified. . 42

Figure 3.2 Stratigraphic framework adapted from (Bache et al., 2014a, Bache et al., 2012a, Etienne et al., 2018, Rouillard et al., 2017).....

Figure 3.3. Seismic stratigraphy cartoon for southern Lord Howe Rise (LHRS) .......... 44 
Figure 3.4. TAN1409-LHRS-16 seismic reflection image (above) and sketch interpretation of Seismic Units U-LHRS-1a, U-LHRS-1b, U-LHRS-2a and U-LHRS-3 (below)

Figure 3.5. 114-06 seismic reflection image (above) and sketch interpretation of Seismic Units U-LHRS-1a, U-LHRS-2a and U-LHRS-2b (below). 47

Figure 3.6. Unit thicknesses in second two-way time (TWT) ...................................48

Figure 3.7. Unit thicknesses in second two-way time (TWT) ..................................49

Figure 3.8. Seismic stratigraphy cartoon for northern Lord Howe Rise (LHRN). ........51

Figure 3.9. 302-009 seismic reflection image (above) and sketch interpretation of Seismic Units U-LHRN-1a, U-LHRN-1b, U-LHRN-2a, U-LHRN-2 $b_{1}$, U-LHRN-2 $b_{2}$ and U-LHRS-3 (below).

Figure 3.10. 302-001 seismic reflection image (above) and sketch interpretation of Seismic Units U-LHRN-1a, U-LHRN-1b, U-LHRN-2a, U-LHRN2b and U-LHRN-3..54 Figure 3.11. Seismic stratigraphy cartoon is modified from Rouillard et al. (2015) illustrating seismic units of Fairway Basin (FWAY)... .56

Figure 3.12. LHRNR-BA seismic reflection image (above) and sketch interpretation of Seismic Units 2b, 2a, 1b and 1a (U2b, U2a, U1b and U1a) in FWAY and NCTN (below).

Figure 3.13. TEC14 seismic reflection image (above) and sketch interpretation of Seismic Units U-FWAY-1a and U-FWAY-2a (below) 58

Figure 3.14. Tec 20 near Site U206, seismic reflection image (above) and sketch interpretation of Seismic Units U-206-1a, U-206-1b and U-206-2a (below) 60

Figure 3.15. Unit thickness in second two-way time (TWT) in FWAY basin 61

Figure 3.16. Seismic stratigraphy cartoon for southern New Caledonia Trough (NCTS)

Figure 3.17. Unit thicknesses in second two-way time (TWT) in NCTS and REIN .....64

Figure 3.18. Seismic stratigraphy cartoon for northern New Caledonia Trough (NCTN).

Figure 3.19. Intersection seismic reflection line TEC 11 and TEC 08 across NCTN (above) and sketch of stratigraphy (below).

Figure 3.20. TEC06 seismic reflection image (above) and sketch interpretation of Seismic Units U-NCTN-1a, U-NCTN-1b and U-NCTN-2a (below) ............................6 68

Figure 3.21. Unit thickness in second two-way time (TWT) in NCTN .......................69

Figure 3.22. Seismic stratigraphy cartoon for Reinga Basin (REIN)......................... 71 
Figure 3.23. REIN09-012 seismic reflection image (above) and sketch interpretation of Seismic Units U-REIN-1a, U-REIN-1b, U-REIN-2a, U-REIN-2b and U-REIN-3 (below)

Figure 3.24. Unit thicknesses in second two-way time (TWT) in REIN basin near Site $\mathrm{U} 1508$

Figure 3.25. Cartoon diagram showing stratigraphy of seismic Units across northern Zealandia 79

Figure 4.1 Depth age relationships at IODP boreholes and DSDP Sites (Burns, 1973a, Burns and Andrews, 1973; Sutherland, pers. comm. 2019; Sutherland, 2019c; Sutherland et al., 2018b). 86

Figure 4.2. IODP Expedition 371 porosity measurements of bathyal pelagic sediment (Sutherland, 2019a, Sutherland, 2019b, Sutherland et al., 2018a)..... 87

Figure 4.3. Seismic stratigraphy of northern of Lord Howe Rise near Site U208......... 89

Figure 4.4. Seismic stratigraphy of northern Lord Howe Rise near Site U1506. .......... 89

Figure 4.5. Seismic line 302-009 on the northern Lord Howe Rise at Site U208..........90

Figure 4.6. Seismic reflection line TAN1409-LHRN-06 through borehole U1506 ......91

Figure 4.7. Borehole DSDP 208 age-depth relationship.......................................... 92

Figure 4.8. Borehole IODP U1506 age-depth relationship......................................93

Figure 4.9. Line graph shows mass accumulation rate over time for the boreholes and seismic reflectors on northern Lord Howe Rise............................................................ 95

Figure 4.10. Seismic stratigraphy for Lord Howe Rise near Site U1510..................... 97

Figure 4.11. Seismic reflection line TAN1409-LHRS-02 at Site U1510 .................... 97

Figure 4.12. Seismic reflection line TAN1409-LHRS-02 through borehole U1510 .....98

Figure 4.13. IODP U1510 age-depth relationship.................................................. 99

Figure 4.14. Seismic stratigraphy for Lord Howe Rise near Site U207..................... 100

Figure 4.15. Seismic stratigraphy for Lord Howe Rise near Site U592...................... 101

Figure 4.16. Seismic reflection line 114_07 at Site U592 and U207......................... 102

Figure 4.17. Seismic line TAN1409-LHRS_01 on the southern Lord Howe Rise at Site

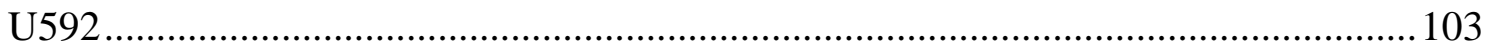

Figure 4.18. Borehole IODP DSDP 207 age-depth relationship............................... 103

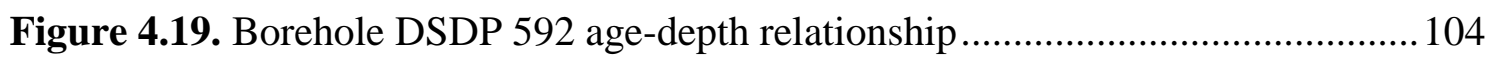

Figure 4.20. The Line graph illustrates a mass accumulation rate over time for the boreholes and seismic reflectors on the southern Lord Howe Rise .............................. 105

Figure 4.21. Seismic stratigraphy for northern New Caledonia Trough near Site U1507 
Figure 4.22. Bathymetry showing failure scars and small canyons at the lower part of

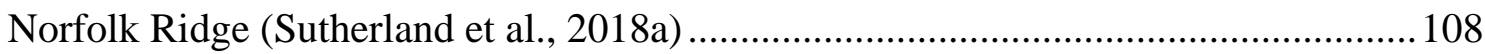

Figure 4.23. Seismic line line TAN1409-NCTN-11 at Site U1507 ............................. 109

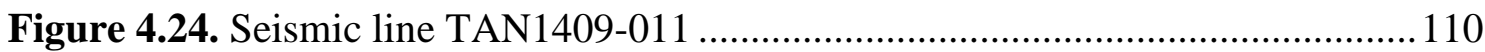

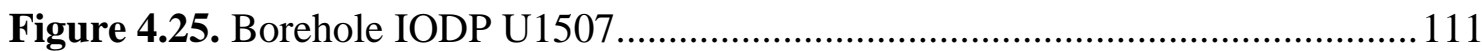

Figure 4.26. Line graph shows mass accumulation rate over time for the boreholes and seismic reflectors in northern New Caledonia Trough

Figure 4.27. Seismic stratigraphy for Reinga Basin near Site U1508 (after Orr et al. 2020)

Figure 4.28. Seismic reflection line REIN09-012

Figure 4.29. Seismic reflection line REIN09-011 illustrates horizons picked and seismic units across the site U1508 in the Reinga Basin

Figure 4.30. Borehole IODP U1508 age-depth relationship 117

Figure 4.31. Line graph shows mass accumulation rate over time for the boreholes and seismic reflectors data in the northern New Caledonia Trough 118

Figure 4.32. Summary of MAR data in northern Zealandia 119

Figure 5.1 Cretaceous and Tertiary stratigraphy of deepwater Taranaki Basin and Present day maturity model (Pepper and Corvi, 1995, Uruski et al., 2003). 132

Figure 5.2 Petroleum system diagram for northern Zealandia. 134

Figure 5.3 Map showing hydrocarbon generation window across northern Zealandia 


\section{List of Tables}

Table 1.1. Seismic acquisition parameters of seismic data used in this study (Sutherland et al., 2012)..... .7

Table 1.2. The numerical solution from Stratford et al., (2018), Sutherland et al., (2018) and Sutherland et al., (219a, b, c) that use as a function of depth to derive single two-way-

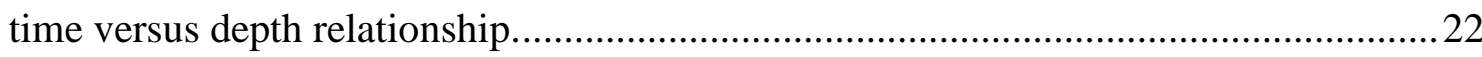

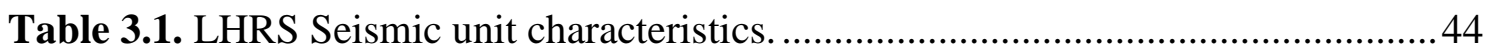

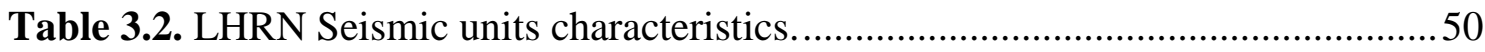

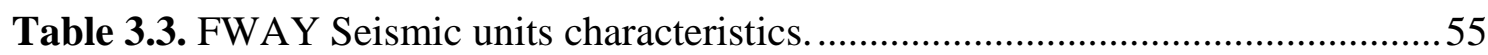

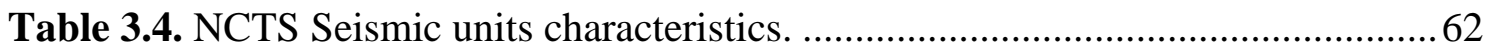

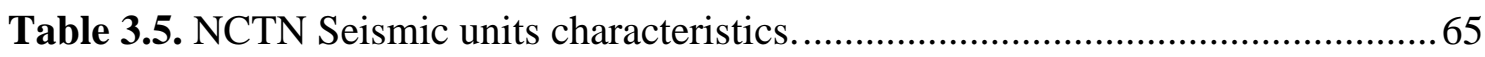

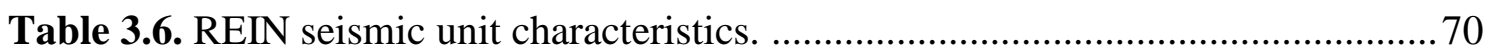




\section{Introduction}

\subsection{Thesis aim, objectives and structure}

The aim of my study is to investigate the classification and mapping of the stratigraphic architecture of northern Zealandia, and hence to provide an updated assessment of hydrocarbon prospectivity. This is achieved by (1) reviewing existing data and interpretations, (2) by analysing newly-acquired well-based data from the International Ocean Discovery Program (IODP) Expedition 371 (Sutherland, 2019a, Sutherland, 2019b, Sutherland et al., 2020), and (3) analysing the new seismic data collected as part of the TECTA and TAN1409 seismic-reflection voyages (Collot et al., 2016, Sutherland et al., 2014, Sutherland et al., 2017).

The stratigraphic succession preserved on the submerged northern Zealandia continent (Fig. 1.1) records the geological evolution of the southwest Pacific and potentially contains hydrocarbon or/and other mineral resources. My investigation of this succession is restricted to data collected by drilling and seismic-reflection methods (Burns, 1973a, Burns and Andrews, 1973, Sutherland et al., 2012, Sutherland et al., 2017).

The region's stratigraphic succession records three tectonic phases: Mesozoic Gondwana subduction margin, Cretaceous rift-drift, and Cenozoic subduction initiation and final burial (Bache et al., 2014a, Mortimer, 2004). The Gondwana subduction margin produced the basement rock consisting of continental fragments. The Gondwana subduction phase resulted in quartzose metasedimentary rocks, granitoids of Palaeozoic and Mesozoic age and lithic-rich metasedimentary rocks formed in a trench-slope environment. Sedimentary rock that was deposited in the marginal seas of Gondwana is very poorly sampled and understood. The Cretaceous rift phase involved intracontinental rifting and extension followed by seafloor spreading and the opening of the Tasman Sea. This period of widespread rifting resulted in normal faulting across northern Zealandia (Uruski and Wood, 1991, Collot et al., 2009, Strogen et al., 2017). Lastly, Cenozoic subduction-related deformation and volcanism has resulted in Eocene-Oligocene unconformity development and deformation of sediment (Sutherland et al., 2017, King, 2000b, Sutherland, 1995, Sutherland et al., 2010, Collot et al., 2008, Stagpoole and Nicol, 2008, Herzer et al., 1997, Herzer, 1995, Schellart et al., 2006). 
Petroleum source rocks may occur within the Mesozoic succession of the Gondwana margin (Bache et al., 2014a). The Mesozoic succession in northern Zealandia is understood to contain coal-bearing sediments such as those identified in the Muhiriku Supergroup, New Zealand (Bache et al., 2014a, Cook et al., 1999, Suggate, 1990) and may be equivalent to Mesozoic successions in Queensland Australia, Papua New Guinea (PNG) and Timor-Leste (Brown et al., 1979, Charlton, 2002, Ingram et al., 1996, O'Brien et al., 1994, Peters et al., 1999). The Murihiku Supergroup rocks comprise Triassic to Jurassic volcanoclastic sandstone, mudstone, and thin bituminuous coals. Strata were mostly deposited in non-marine conditions but intercalated shell beds indicate episodic marine flooding (Suggate, 1990, Cook et al., 1999). Similarly, organic-rich rocks have been found in the Jurassic Walloon Coal Measures and the Koukandowie Formation of Queensland, Australia (Ingram et al., 1996). The Walloon Coal Measures were deposited in fluvial and lacustrine environments (Ingram et al., 1996). Clay rich marine source rocks have been observed in the Late Jurassic Imburu Formation of western PNG containing terrigenous organic matter (Waples and Wulff, 1996). Similar aged source rocks have been identified in Timor-Leste, where the primary potential source rocks have been found in the restricted marine mixed carbonate and clastic sequence of Late Triassic age (Charlton, 2002).

Cretaceous sedimentation in northern Zealandia occurred in a series of rift basins, which formed during the break-up of eastern Gondwana and subsequent Paleogene events, which may have affected the petroleum accumulation in this region. Cretaceous rift basins may contain coaly sediment facies (petroleum source rocks) overlain by transgressive marine sandstone and mudstone (petroleum reservoir and seal rocks) (Bache et al., 2014a, King and Thrasher, 1996). During Cretaceous time, the region experienced transgression that resulted in early terrestrial deposits succeeded by a thick interval of non-marine and marine graben-filling sediments, including coastal and shelf sands and bathyal muds (Stagpoole et al., 2009). The Paleogene was characterised by deposition of fine-grained sediments and represents the passive filling of the basin after rifting. Paleogene tilting altered the petroleum migration pathways and created traps. These Cretaceous-Paleogene transgressive sedimentary rocks form the basis of well-known petroleum systems in the Gippsland and Taranaki basins (King and Thrasher, 1996). 
Subduction initiation changed the geography, crustal thickness, and crustal composition across northern Zealandia (Sutherland et al., 2020), and caused 1-3 km elevation changes in the region. These changes may relate to crust delamination and mantle flow that led to slab formation (Sutherland et al., 2020, Sutherland et al., 2010). Subduction rupture triggered lithospheric-scale faults across northern Zealandia and further tectonic forces occurred as subducted slabs grew in size and hence changed the plate-motion. Widespread uplift was followed by subsidence and crustal deformation in response to the subduction initiation at the plate boundary (Sutherland et al., 2010). The resulting Eocene-Oligocene deformation affected some strata in the region which experienced folding and reserve faulting.

Based on the geological history of the region, I identify three components of study. Firstly, I identify 'acoustic basement' in the study area that may have petroleum source rock potential. Secondly, I review the rift-drift to subduction-related stratigraphic succession, to assess petroleum prospectivity. Finally, I analyse the maturity, migration, and potential charge that has occurred in a stable Neogene tectonic environment. An understanding of the sedimentary and oceanic system since the Oligocene in the study area is critical for this last objective.

The structure of the thesis is based on work components to address each objective. (1) Identify the acoustic basement from seismic reflection data and try to interpret the 'basement' in term of possible Gondwana origin because it may be an indication of source rock. (2) Review and improve the mapping and understanding of Cretaceous-Paleogene stratigraphic architecture, which is essential for assessment of the basic components of any petroleum system (source rocks, reservoir rocks, seal rocks and trapping mechanism).

(3) Identify Cenozoic burial and maturity history from detailed mapping of as many reflectors where age control at boreholes can be confidently tied to seismic reflectors. The distribution of Cenozoic sediments may further reveal clues to the oceanographic, thermal evolution, current-controlled deposition history and sedimentary location since the Oligocene. (4) Conduct a petroleum system analysis of northern Zealandia and evaluate petroleum prospectivity of the region. 


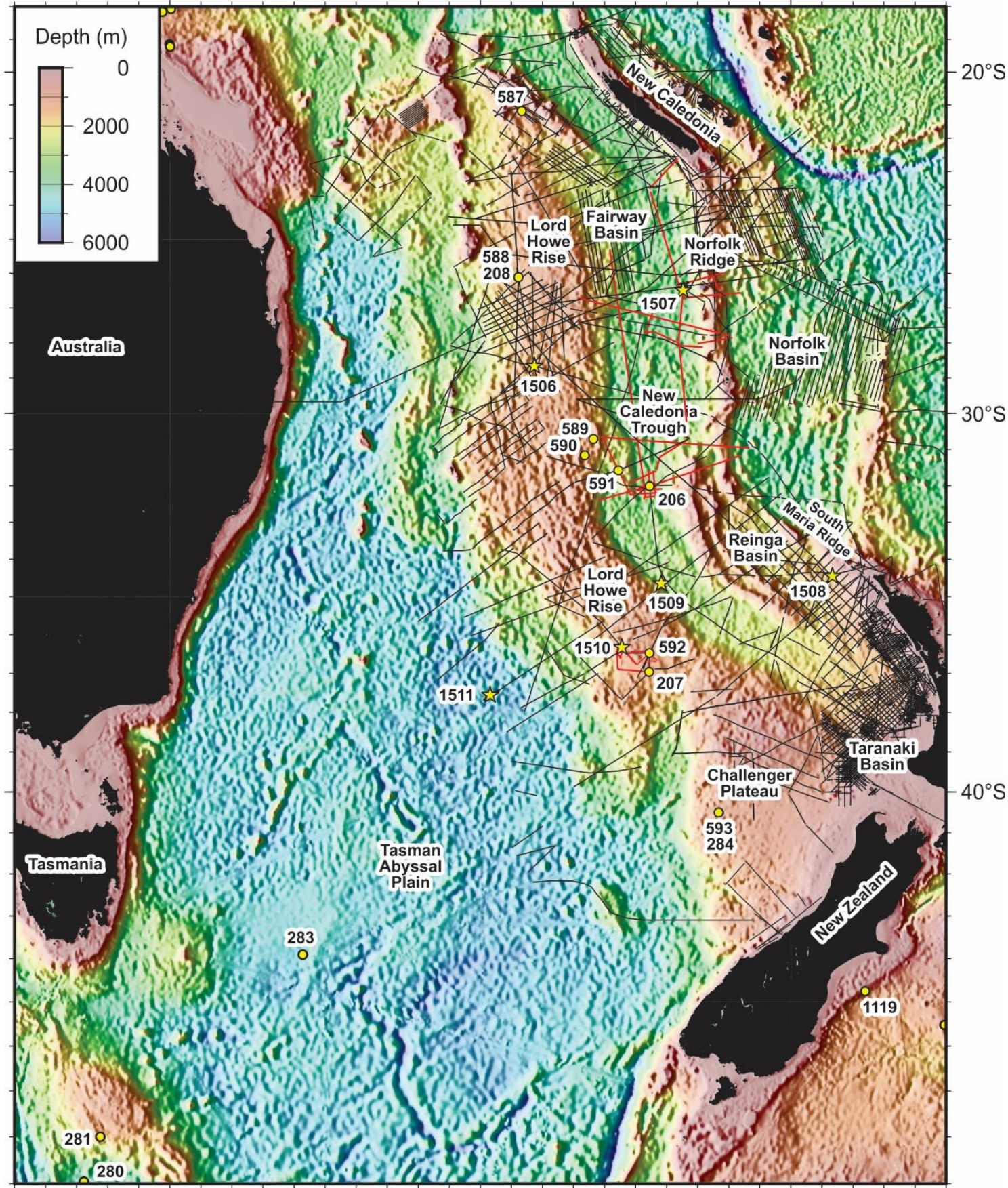

Figure 1.1. Northern Zealandia bathymetric map showing the location and distribution of seismic data (black lines $=$ existing surveys $\&$ red lines =TAN1409 \& TECTA survey) showing relationship of study area to east Australia and New Caledonia. Boreholes represent yellow circles and stars. Yellow star = IODP borehole; yellow circle = DSDP borehole . 


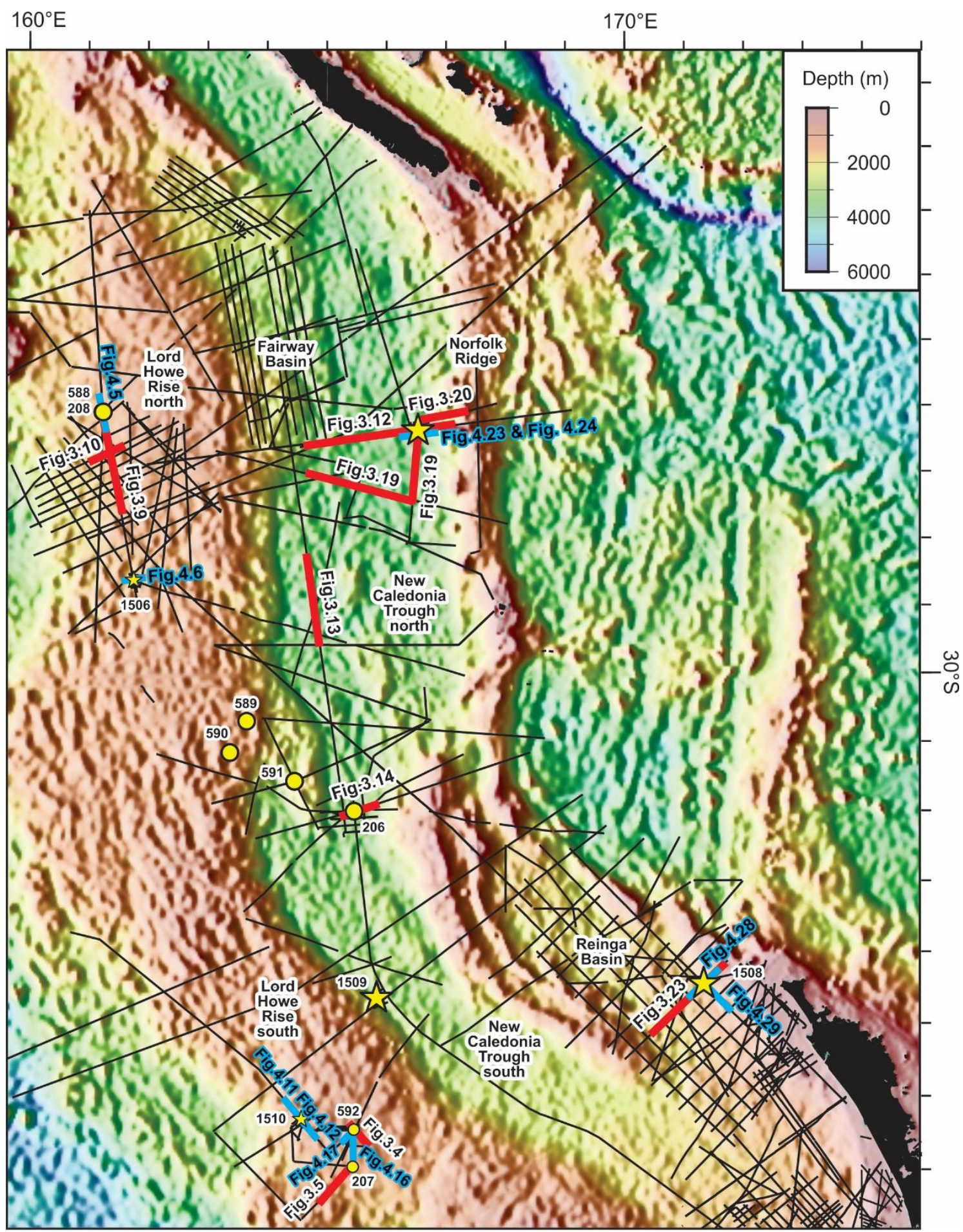

Figure 1.2. Bathymetric map of northern Zealandia showing the location and distribution of seismic data (black lines), boreholes (yellow star \& circle) and figures used in this study. Red lines = figures used in chapter 3 and light blue lines = figures used in chapter 4 . 


\subsection{Seismic reflection data}

Seismic reflection data of the study area consist of multi-channel 2D data (1879 lines) (Fig. 1.1). I made detailed interpretations during this study of 217 seismic lines $(39,309$ line km; Fig. 1.2 and Table 1.1) covering > 1,000,000 $\mathrm{km}^{2}$ from the Challenger Plateau in the south, to north of Lord Howe Rise, including Fairway Basin, New Caledonia Trough and Norfolk Ridge (Fig. 1.2).

Seismic reflection surveys record seismic pulses returning to the surface after reflection off concealed interfaces. An acoustic impedance is the product of velocity and density, and seismic reflections arise at boundaries across which acoustic impedance changes. Reflection will not occur if the impedance does not change, even if there is a lithology change. The reflection will be stronger (higher amplitude) where there is a larger difference in acoustic impedance across the layer. The reflection coefficient $(\mathrm{RC})$ is the ratio of incident to reflected amplitude and can be expressed for normal incidence as:

$$
R C=\left(\frac{I_{2}-I_{2}}{I_{2}-I_{2}}\right)
$$

Where $\mathrm{I}_{1}$ and $\mathrm{I}_{2}$ are impedances of the top and bottom layers.

I particularly focus on twelve surveys (see Table 1.1): 114 (Australian Geological Survey Organization), S206 (Australia Geological Survey Organisation), ZoNeCo-5 (IFREMER), lhrnr-b-nz (New Zealand UNCLOS program), 232 (Geoscience Australia/Service des Mines et de I'Energie), ZoNeCo-11 and Noucaplac-2 (French UNCLOS program), 302 (Geoscience Australia survey), STRAT09 (CGG Veritas Marine), and REI09 (CGG). New seismic surveys include the TAN1409 and TECTA surveys (Loubrieu et al., 2004, Lafoy et al., 1998, Collot et al., 2016). These seismic lines zig-zag from southwest to northeast crossing the Lord Howe Rise (Lord Howe Rise South \& Lord Howe Rise North), Fairway Basin, Reinga Basin and New Caledonia Trough. Table 1.1 gives details of each survey (Fig. 1.2).

The TAN1409 voyage objective was to understand the process of subduction initiation and Paleogene climate (Sutherland et al., 2014). It surveyed six sites for IODP 
Expedition 371 drilling (sites 1506-1511, Fig.1.1). The purpose was to document a detailed grid of high-resolution data at each potential IODP site.

The TECTA seismic survey was designed to link the TECTA voyage with existing surveys (Fig. 1.1) (Collot et al., 2016). The TECTA voyage was placed to connect Fairway Basin, Lord Howe Rise and Norfolk Ridge data with northern New Caledonia Trough, and hence to IODP sites and DSDP Site 206 (See Fig. 1.2 \& Table. 1.1).

Table 1.1. Seismic acquisition parameters of seismic data used in this study (Sutherland et al., 2012).

\begin{tabular}{|l|c|c|c|c|c|c|c|c|}
\hline \multicolumn{1}{|c|}{ Survey } & Year & $\begin{array}{c}\text { Line } \\
\mathbf{( K m})\end{array}$ & $\begin{array}{c}\text { Streamer } \\
\text { Length } \\
\mathbf{( k m})\end{array}$ & $\begin{array}{c}\text { Number } \\
\text { of } \\
\text { channels }\end{array}$ & $\begin{array}{c}\text { Receiver } \\
\text { immersion } \\
(\mathbf{m})\end{array}$ & $\begin{array}{c}\text { Source } \\
\text { volume } \\
(\mathbf{c u})\end{array}$ & $\begin{array}{c}\text { Source } \\
\text { type }\end{array}$ & $\begin{array}{c}\text { Shot } \\
\text { interval } \\
(\mathbf{m})\end{array}$ \\
\hline 114 & 1992 & 756.2 & 3 & 120 & 15 & 3000 & Airgun & 50 \\
\hline GA-206 & 1998 & 3409 & 3.3 & 264 & 10 & 3000 & $\begin{array}{c}\text { First } \\
\text { peak }\end{array}$ & 50 \\
\hline ZoNeCo-5 & 1995 & 8554 & 6 & 6 & 7 & N/A & $\begin{array}{c}\text { First } \\
\text { peak }\end{array}$ & 50 \\
\hline Lhrnr-b-nz & 2000 & & N/A & N/A & N/A & N/A & Airgun & 50 \\
\hline 232 & 2001 & 2410 & 3 & 24 & 8 & 90 & Airgun & 50 \\
\hline ZoNeCo-11 & 2004 & 2606 & 4.5 & 360 & 15 & 8000 & $\begin{array}{c}\text { Single } \\
\text { Bubble }\end{array}$ & 150 \\
\hline $\begin{array}{l}\text { Noucaplac- } \\
2\end{array}$ & 2004 & 1945 & 4.5 & 360 & 15 & 8000 & $\begin{array}{c}\text { Single } \\
\text { Bubble }\end{array}$ & 75 \\
\hline GA-302 & $2006-$ & 5815 & 8 & 636 & 10 & 4140 & Airgun & 37.5 \\
\hline STRAT09 & 2007 & 1464 & 7.9 & 636 & 7 & 4140 & Airgun & 37.5 \\
\hline $\begin{array}{l}\text { CGG- } \\
\text { REI09 }\end{array}$ & 2009 & 5216 & 7.9 & 636 & 7 & 5000 & $\begin{array}{c}\text { Single } \\
\text { bubble- } \\
\text { bolt/mini } \\
\text { GI }\end{array}$ \\
\hline TAN1409 & 2014 & 1361.2 & 5 & 48 & 5 & $45 / 105$ & $\begin{array}{c}\text { A single } \\
\text { GI gun }\end{array}$ \\
\hline TECTA & 2015 & 5049 & 4.5 & 720 & 7 & 2690 & Airgun & 25 \\
\hline
\end{tabular}

The quality of seismic data is variable. Multiple energy is a problem on many surveys. Seismic surveys across Fairway Basin vary from poor-quality single-channel lines to high-resolution, low penetration (1.5 s twt) six-channel seismic data acquired during the ZoNeCo-5 voyages (Rouillard et al., 2017). Reinga Basin has high-quality survey data collected in 2009.

Interpretation of seismic reflection data was performed on a workstation using SeisWare Geophysics (version 10.0). No bulk shifts were applied, because objectives were regional in nature. 


\subsection{Borehole data}

Seismic reflectors were tied to Deep Sea Drilling Program (DSDP) Legs 21 and 90 (Fig. 1.3 \& 1.4) (Burns, 1973a, Burns and Andrews, 1973, Kennett and von der Borch, 1986), International Ocean Discovery Program (IODP) Expedition 371 (Burns and Andrews, 1973, Sutherland et al., 2018a, Sutherland et al., 2012), and dredge and core samples (Fig. 1.1, Fig. 1.5).

DSDP Leg 21 drilled sites 206, 207 and 208 in September - December 1971 (Fig. 1.3) (Burns, 1973a, Burns and Andrews, 1973). Site U206 was drilled just east of a smallelongated rise on the deepest part of the southern section of New Caledonia Trough (Fig. 1.1). The location was parallel to the trend of Lord Howe Rise to the west and Norfolk Ridge to the east. Sites U207 and U208 were drilled on Lord Howe Rise (Fig.1.1).

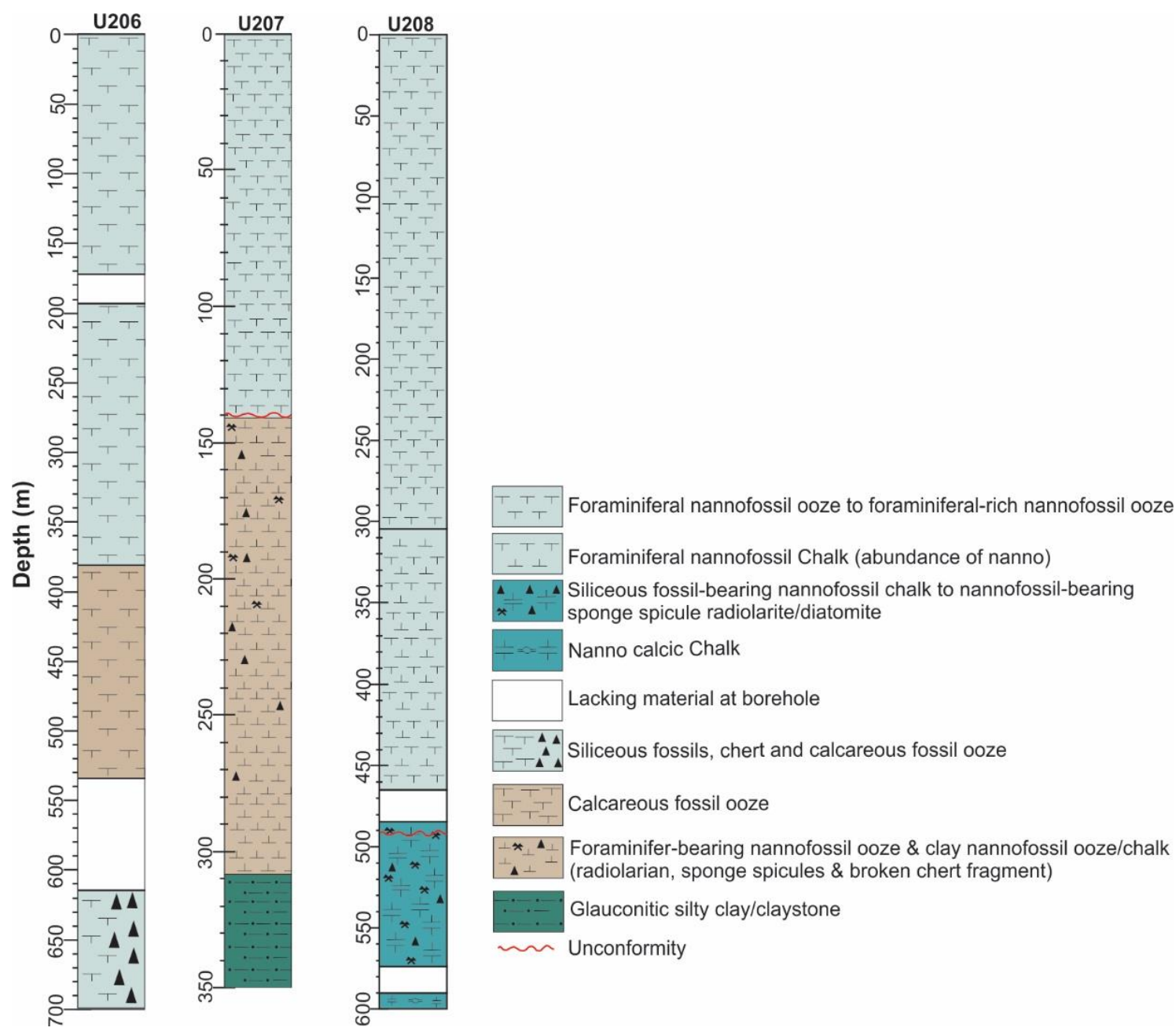

Figure 1.3. Stratigraphic columns of DSDP Leg 21 (boreholes U206, U207 \& U208). Adapted from (Burns and Andrews, 1973, Burns et al., 1973a, Burns et al., 1973b). 
Site U206 was cored to a depth of 734 (mbsf) with a water depth of 3196 m (Fig. 13) (Burns, 1973a, Burns and Andrews, 1973). There were 67 cores obtained at Site U206. The stratigraphic succession was divided into four units. Unit $1(0-389 \mathrm{mbsfs})$ contained early Miocene to Pleistocene nannofossil ooze with variable quantities of foraminifera and minor volcanic ash. Unit 2 (389 - 614 mbsf) was middle Oligocene to early Miocene semi-lithified clayey nannofossil ooze. Unit 3 (614 - 677 mbsf) was middle to late Eocene semi-lithified, radiolarian-rich nannofossil ooze. Unit 4 (677 - 734 mbsf) was early Palaeocene to middle Eocene nannofossil chalk and clay with minor chert.

Site U207 penetrated to a depth of 513 mbsf with a water depth of 1389 m (Fig. 13) (Burns, 1973a, Burns and Andrews, 1973). Fifty-five cores were collected (5 in hole 207 and 50 in hole 207A). Unit 1 (0 - $142 \mathrm{mbsf}$ ) comprised middle Miocene to Pleistocene foraminiferal nannofossil ooze and nannofossil foraminiferal ooze. Unit 2 (142 - 309 mbsf) was Palaeocene to middle Miocene foraminiferal and nannofossil ooze to foraminiferal-bearing nannofossil ooze and clayey nannofossil ooze or chalk with subordinate siliceous fossil-bearing foraminiferal-nannofossil ooze. Unit 3 (309 to 357 mbsf) was Maastrichtian glauconitic silty claystone (sandstone at the very base). Unit 4 (357 to $433 \mathrm{mbsf}$ ) was Upper Cretaceous rhyolitic (pumiceous) lapilli tuffs, and vitrophyric rhyolite flows that were more fragmented in part. Unit 5 (433 to $513 \mathrm{~m}$ ) was Upper Cretaceous or older and Vitrophyric rhyolite flows, fragmented in part.

Site U208 penetrated to a depth of 594 mbsf in water depth 1545 m (Fig. 13) (Burns, 1973a, Burns and Andrews, 1973) and collected 34 cores. Unit 1 (0 to 488 mbsf) was late Oligocene to late Pleistocene unconsolidated to semi-lithified, foraminiferal nannofossil ooze to foraminiferal-rich nannofossil ooze with subordinate nannofossil foraminiferal ooze and foraminiferal-bearing nannofossil ooze. Unit 2 (488 to $594 \mathrm{mbsf}$ ) was composed of Late Cretaceous to middle Eocene siliceous fossil-bearing nannofossil chalk to nannofossil-bearing radiolarite or diatomite and chalk.

DSDP Leg 90 was conducted during December 1982 to January 1983 and recovered more than $3700 \mathrm{~m}$ of sediment cores from eight sites (587 - 594) (Kennett and von der Borch, 1986, Kennett et al., 1985) (Fig.1.1). The primary objective of Leg 90 was to define paleoceanographic history including the surface and bottom-water circulation pattern, and the biogeographic development of planktonic and benthic species (Kennett 
and von der Borch, 1986, Kennett et al., 1985). Site U592 was drilled with the objective of comparing the sedimentation rate of calcareous biogenic ooze with other Leg 21 and 90 sites and of providing another late Neogene sequence of shallow-water benthic foraminifers (Fig. 1.4).
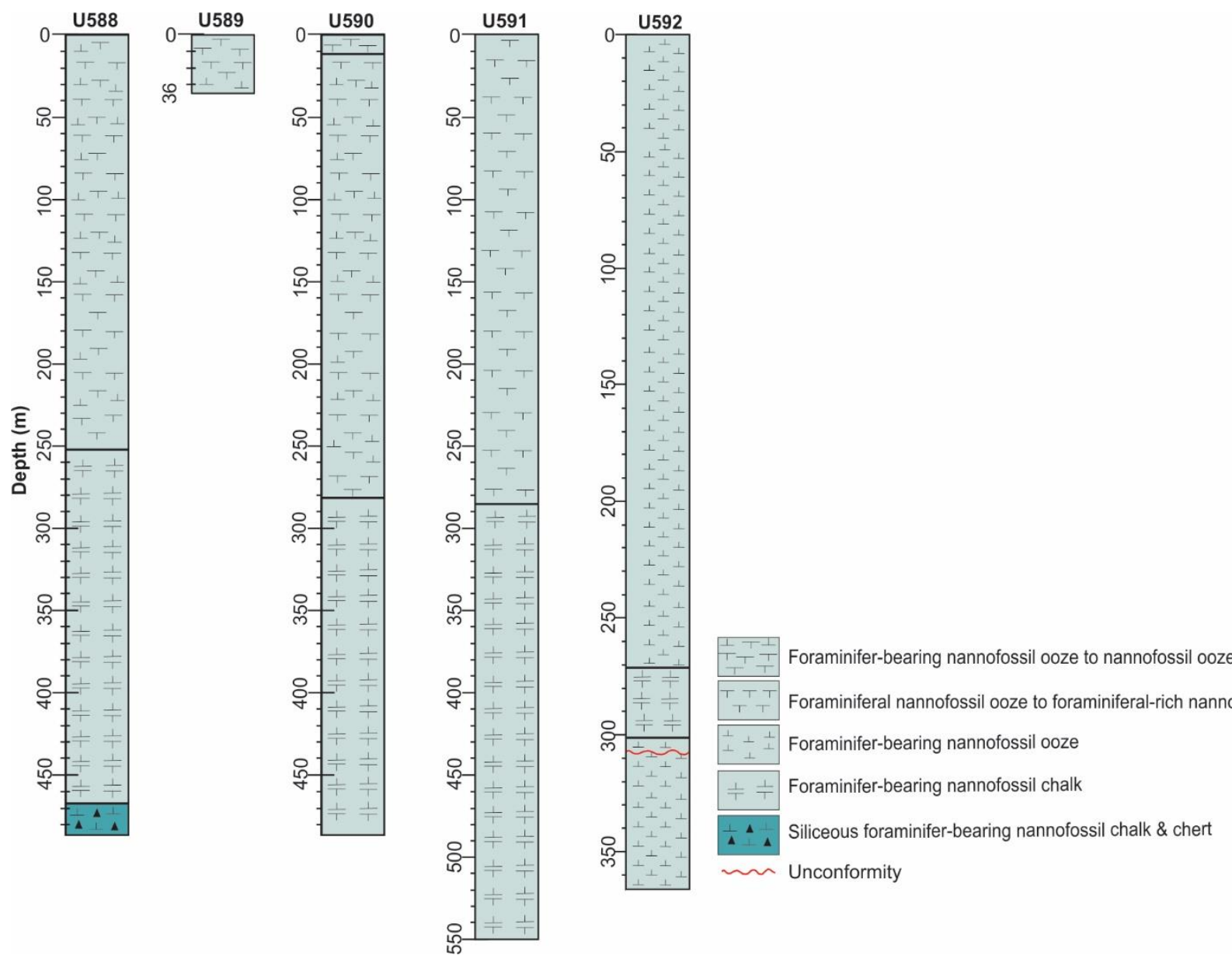

Figure 1.4. Stratigraphic columns of DSDP Leg 90 (boreholes U588, U589, U590, U591 \& U592). Adapted from (Kennett et al., 1986a, Kennett et al., 1986b, Kennett et al., 1986c, Kennett et al., 1986e, Kennett et al., 1986d)

Site U588 was located very near $(1.3 \mathrm{~km})$ to DSDP Site 208 but had greatly superior core recovery in 4 holes (Fig. 1.4) (Kennett et al., 1986c). Hole 588 cored from 0 to 236 m sub-bottom. Hole 588A continued core from 236 to $344.4 \mathrm{~m}$. Hole 588B cored from 0 to $277.4 \mathrm{~m}$ and Hole $588 \mathrm{C}$ was core from 305.7 to $488.1 \mathrm{mbsf}$. Site U588 penetrated to a depth of 488.1 mbsf with a water depth of $1533 \mathrm{~m}$. The section was divided into two sedimentary units, based on color and composition. Subunit 1A (0-6.6 or 6.8 mbsf) was Quaternary grayish orange to yellowish brown foraminifer-bearing nannofossil ooze. Subunit 1B (6.6-250 mbsf) contained Quaternary to middle Miocene white to light gray foraminifer-bearing nannofossil ooze to nannofossil ooze. Subunit 1C (226-469 mbsf) 
was middle Miocene to late Oligocene white to light gray to light greenish gray, foraminifer-bearing nannofossil chalk to nannofossil chalk. Unit 2 (469-488.1 mbsf) was middle Eocene light greenish gray siliceous foraminifer- bearing nannofossil chalk and chert.

Site U589 penetrated a depth of 36.1 mbsf in water depth $1391 \mathrm{~m}$ (Fig. 1.4) (Kennett et al., 1986d). The stratigraphic section was divided into two subunits that were distinguished by color, grain size and compaction. Subunit $1 \mathrm{~A}$ (0-0.4 mbsf) contained late Pleistocene foraminiferal-nannofossil ooze of greyish orange color and had a coarse grain size. Subunit 1B (0.4- $36.1 \mathrm{mbsf})$ was early Pleistocene foraminiferal-nannofossil ooze to nannofossil ooze with colors of light greenish gray and pale olive to white and very light gray.

Site U590 was drilled to a depth of 449.1 mbsf in a water depth of 1299 m (Fig. 1.4) (Kennett et al., 1986a). The section was predominantly calcareous biogenic sediments and could be divided into three subunits. Subunit 1A (0-04 mbsf) was late Quaternary yellowish orange foraminifer-nannofossil ooze. Subunit 1B (0.4-280.8 mbsf) contained late Miocene very light gray foraminifer-bearing nannofossil ooze to light olive gray foraminifer-nannofossil ooze. Subunit 1C (278.1-499.1) late Miocene to early Miocene light gray foraminifer-bearing nannofossil chalk to recrystallized nannofossil chalk.

Site U591 penetrated to a depth of 500.4 msbf in water depth $2131 \mathrm{~m}$ (Fig. 1.4) (Kennett et al., 1986e). The stratigraphic sequence at Site 591 was divided into three subunits. Subunit 1A (0-6.2 mbsf) was late Quaternary yellowish gray to pale yellowishbrown foraminifer-bearing nannofossil ooze. Subunit 1B (6.2-289.8 mbsf) was composed of Quaternary to upper Miocene light gray foraminifer-bearing nannofossil ooze to a nannofossil ooze. Subunit IC (289.8-500.4 mbsf) consisted ofnlate Miocene to early Miocene very light gray to light greenish gray chalk and ranged from a foraminiferbearing nannofossil chalk to a nannofossil chalk.

Site U592 penetrated to a depth of 388.5 mbsf and was drilled in a $1088 \mathrm{~m}$ water depth on the southern Lord Howe Rise (Fig. 1.4) (Kennett et al., 1986b). The section was divided into five subunits. Subunit 1A (0-0.3 mbsf) consisted late Quaternary very pale orange to pinkish gray foraminifer-bearing nannofossil ooze. Subunit 1B (0.3-273.3 mbsf) was late Quaternary to early Miocene white to light gray foraminifer-bearing 
nannofossil ooze to nannofossil ooze. Subunit 1C (273.3-305.8 mbsf) contained early Miocene white to very light greenish gray foraminifer-bearing nannofossil chalk to nannofossil chalk. Subunit 1D (305.8-350.1 mbsf) was composed of early Oligocene to late Eocene white to very light gray nannofossil ooze. Subunit 1E (350.1-388.5 mbsf) was late Eocene white to very light gray nannofossil chalk.

The International Ocean Discovery Program (IODP) Expedition 371 of the R/V JOIDES Resolution drilled six sites (U1506-U1511) between 27 July and 26 September 2017 (Fig. $1.1 \&$ 1.5) (Sutherland et al., 2018a). The primary objective of IODP 371 was to obtain information on Tonga-Kermadec subduction initiation through investigation of the Paleogene sediment record (Sutherland et al., 2018a). The secondary objective was to understand regional oceanography and climate since the Paleogene. 


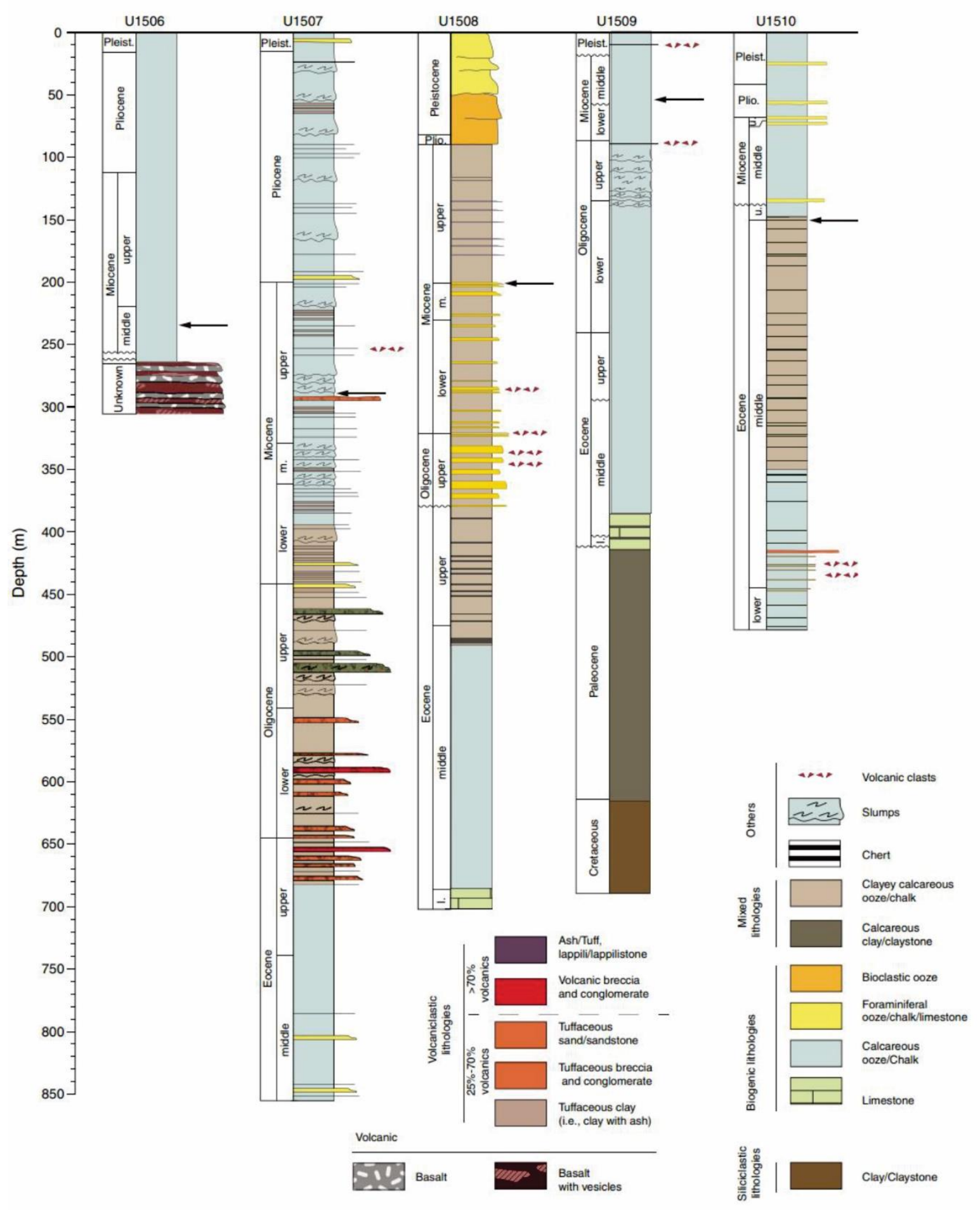

Figure 1.5. Stratigraphy columns showing main lithology at the IODP boreholes (Adapted from (Sutherland, 2019b) 


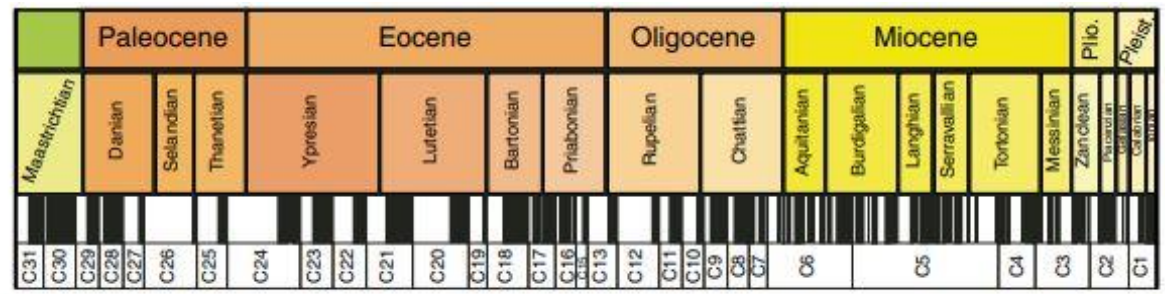

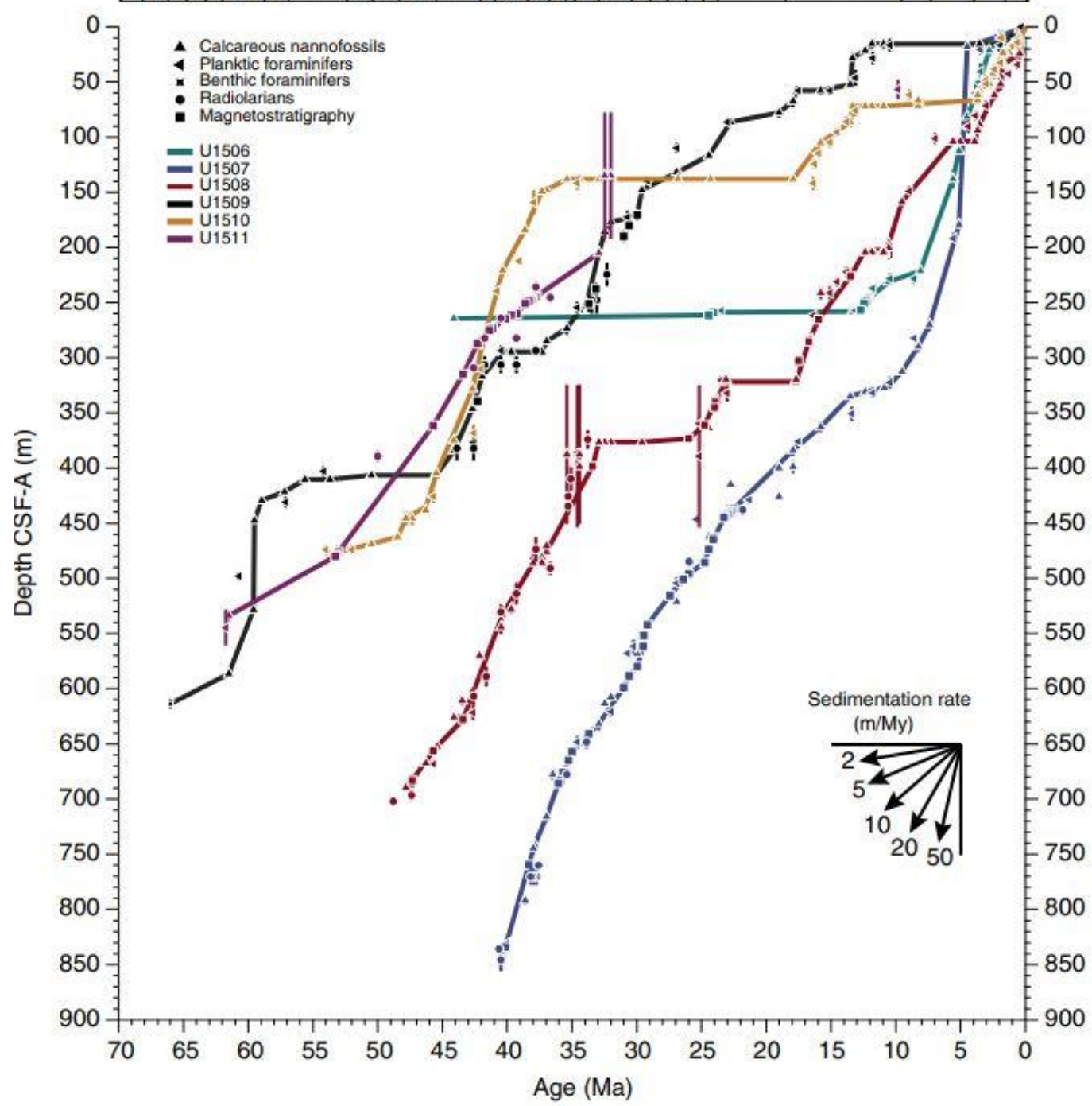

Figure 1.6. Age-depth models for each IODP sites (Sutherland, 2019b).

Site U1506 penetrated to a depth 306.07 mbsf with a water depth of 1505 m (Fig. 1.5 \& 1.6) (Sutherland, 2019b). Site U1506 was $265 \mathrm{~m}$ of Pleistocene-middle Eocene nannofossil ooze and chalk overlying $40 \mathrm{~m}$ of volcanic rock. The succession was divided into two units, and the upper sequence was further divided into three subunits. Subunit IA (0.00-258.23 mbsf) contained homogeneous Pleistocene to middle Miocene white nannofossil ooze and chalk with varying amounts of foraminifers. Subunit IB (258.23264.29 mbsf) was late Oligocene pale yellow nannofossil chalk. Subunit IC (264.29$264.63 \mathrm{mbsf}$ ) was composed of middle Eocene light greenish gray nannofossil chalk. Unit 
II (264.29-264.63 mbsf) consisted of a sequence of mafic crystalline volcanic rocks with a range of textures and mineralogy and varying amounts of carbonate as veins and void infills.

Site U1507 penetrated to a depth 855.64 mbsf with a water depth of 3568 m (Fig. 1.5 \& 1.6) (Sutherland, 2019b).Site U1507 was made up of $685 \mathrm{~m}$ of Pleistocene to upper Eocene biogenic ooze and chalk interbedded with calcareous and volcaniclastic turbidites overlying $170 \mathrm{~m}$ of more homogeneous clayey nannofossil chalk. The section was divided into two units and the upper part further divided into three subunits. Subunit 1A (0.00401.19 mbsf) was Pleistocene to lower Miocene nannofossil ooze and chalk with varying amounts of clay interbedded with foraminiferal ooze, chalk and limestone, nannofossilrich clay with ash, and rare volcaniclastic layers. Subunit 1B (401.19- 542.9 mbsf) was composed of lower Miocene to upper Oligocene clayey nannofossil chalk with varying amounts of foraminifers, volcanic ash, and clasts interbedded with foraminiferal limestone and tuffaceous conglomerate and sandstone. Subunit 1C (542.90-685.52 mbsf) contained lower Oligocene to upper Eocene volcaniclastic sandstone and conglomerate alternating with clayey calcareous chalk with ash and foraminiferal limestone. Unit II (685.52-855.64 mbsf) was upper to middle Eocene clayey nannofossil chalk and limestone interbedded with rare foraminiferal limestone.

Site U1508 penetrated to a depth 701.92 mbsf with a water depth of 1609 m (Fig. 1.5 \& 1.6) (Sutherland, 2019b). Site U1508 was composed of $700 \mathrm{~m}$ of Pleistocene to lower Eocene foraminiferal ooze with varying amounts of nannofossil and coarse-grained bioclasts, and calcareous ooze and chalk with different amounts of clay. Unit 1 (0.00$90.08 \mathrm{mbsf}$ ) was Pleistocene to Pliocene foraminiferal ooze with varying amounts of nannofossils and coarse-grained bioclasts. Unit IIA (90.08-200.93 mbsf) contained Pliocene to upper Miocene clayey nannofossil ooze with varying amounts of foraminifers and sponge spicules and rare ash layers. Unit IIb (200.61- $324.28 \mathrm{mbsf}$ ) was middle Miocene to upper Oligocene interbedded foraminiferal ooze and chalk with varying concentrations of clay, silicate minerals, and volcanic clasts. Unit IIIA (379.30-491.61 mbsf) was composed of upper Eocene to middle Eocene clayey nannofossil chalk with sporadic centimeter-scale siliceous intervals (cherty limestone). Unit IIIB (493.80$701.92 \mathrm{mbsf}$ ) was middle Eocene to lower Eocene nannofossil chalk and nannofossil limestone with foraminifers. 
Site U1509 penetrated to a depth 701.92 mbsf with a water depth of $2911 \mathrm{~m}$ (Fig. 1.5 \& 1.6) (Sutherland, 2019b). Site U1509 was comprised of $415 \mathrm{~m}$ of Pleistocene to upper Palaeocene calcareous ooze, chalk and limestone overlying $275 \mathrm{~m}$ of Palaeocene to Upper Cretaceous claystone. The section was divided into two units. Subunit IA (0-99.60 mbsf) was Pleistocene to upper Oligocene calcareous ooze and chalk with rare tuffaceous beds. Subunit IB (99.60-139.28 mbsf) was composed of upper to lower Oligocene slumped calcareous chalk. Subunit IC (139.28-414.57 mbsf) contained lower Oligocene to upper Paleocene calcareous chalk and limestone with biosilica and chert. Subunit IIA (414.57$614.20 \mathrm{mbsf}$ ) was Paleocene calcareous claystone. Subunit IIB (614.20-689.68 mbsf) contained Upper Cretaceous claystone.

Site U1510 penetrated to a depth $478.1 \mathrm{mbsf}$ with a water depth of $1238 \mathrm{~m}$ (Fig. 1.5 \& 1.6) (Sutherland, 2019b). Site U1510 contained $138 \mathrm{~m}$ of Pleistocene to middle Miocene calcareous ooze overlying $340 \mathrm{~m}$ of upper to lower Eocene calcareous ooze and chalk interbedded with cherty limestone and chert and rare volcanic layers. Subunit IA (0.0-60.0 mbsf) was Pleistocene to Pliocene Color-banded calcareous ooze alternating with discrete beds of foraminiferal ooze. Subunit IB (60.0-66.6 mbsf) was composed of Pliocene to lower Miocene homogeneous calcareous ooze alternating with discrete beds of foraminiferal ooze. The stratigraphic section was separated into two units. Subunit IIA (138.0-147.5 mbsf) contained upper Eocene calcareous ooze with bioclasts accompanied by extra clasts of chert, cherty limestone, and lithics. Subunit IIB (147.5-349.4 mbsf) was upper Eocene to middle Eocene clayey calcareous chalk with bioclasts punctuated by common cherty limestone and chert. Subunit IIC (349.4-478.1 mbsf) consisted of middle Eocene to lower Eocene homogeneous calcareous chalk with chert interbedded with sparse volcaniclastic deposits.

\subsection{Seismic stratigraphy}

Seismic horizons were identified based on principles of seismic stratigraphy (Fig 1.7 \& 1.8). Seismic stratigraphy provides a framework for seismic mapping and interpretation of depositional setting, facies and geological history (Mitchum Jr et al., 1977a, Mitchum Jr et al., 1977b, Vail et al., 1977) (Fig. 1.7). Seismic facies are defined using characteristics of seismic reflection amplitude, configuration, continuity and polarity (Mitchun Jr et al., 1977b). (Fig. $1.7 \& 1.8$ ). 
Each sequence bounding reflector was identified based on stratal terminations that occurred above and below that stratigraphic surface (Fig. 1.7) (Mitchum Jr et al., 1977a, Mitchum Jr et al., 1977b). Onlap and truncation are identified as up-dip terminations of strata against a basal or overlying surface, and truncations indicate either erosional hiatus or structural disruption (Vail et al., 1977) (Fig $1.7 \&$ 1.8). Downlap is down-dip termination of strata against a basal surface at shallower dip (Fig. 1.7A \& B). Onlap, downlap and toplap can be interpreted as non-depositional hiatuses. Seismic units were identified using stratal termination relationships and the geometry of intervening reflectors (stacking pattern), which indicate discreet units separated by structural disruption, sediment supply changes, or unconformities.

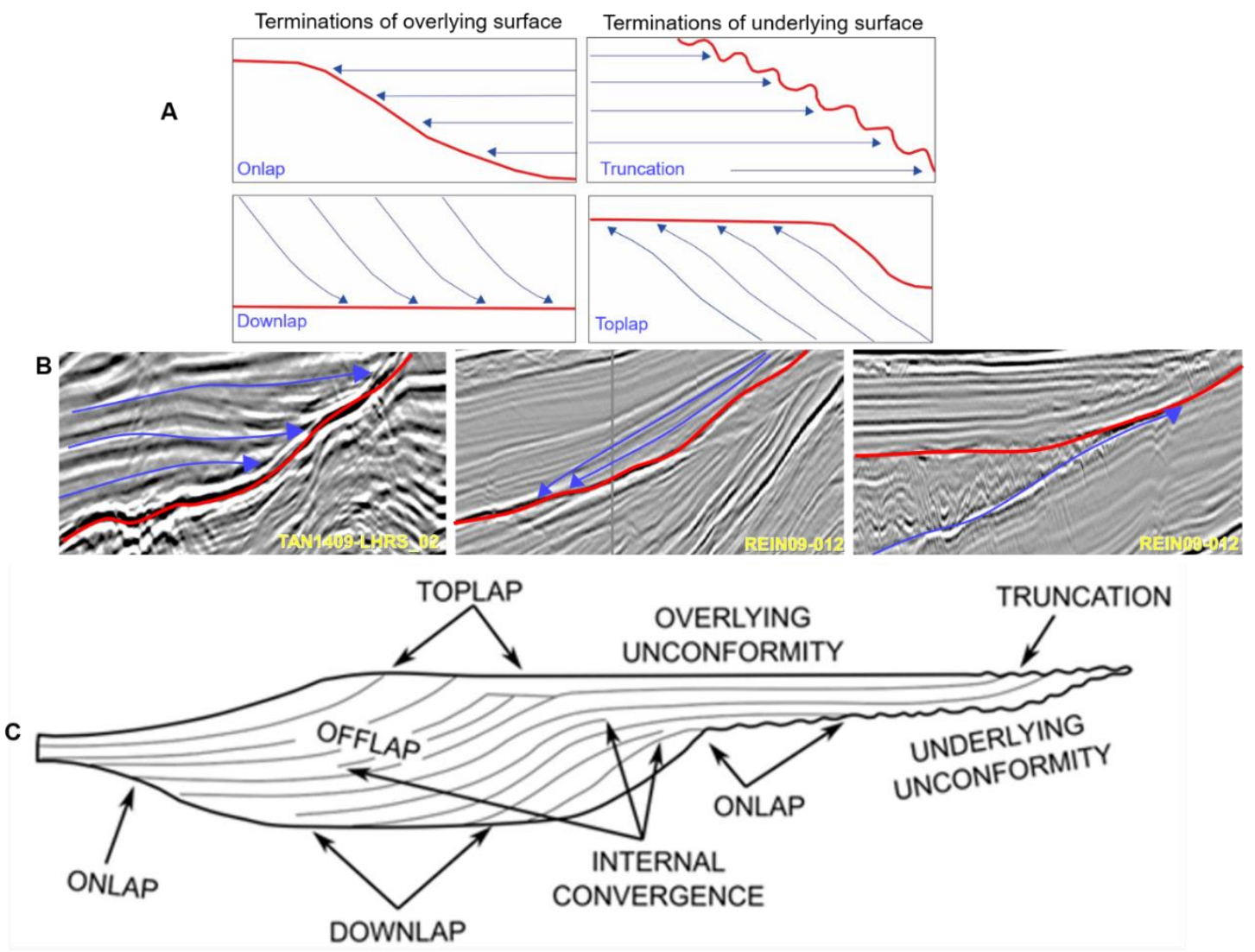

Figure 1.7. Stratigraphy relationships adapted from Catuneanu et al., (2009) and Mitchum et al (1977) used to map seismic stratigraphy in the study area. (A) Relationship to termination of overlying and underlying reflectors. (B) Reflector configuration seen on seismic reflection data in the study area. Horizons interpretation in the study area are represented by the blue surface based on its relationship where terminations occur above and below a stratigraphy surface. (C) Stratigraphy relationships used for seismic mapping. 


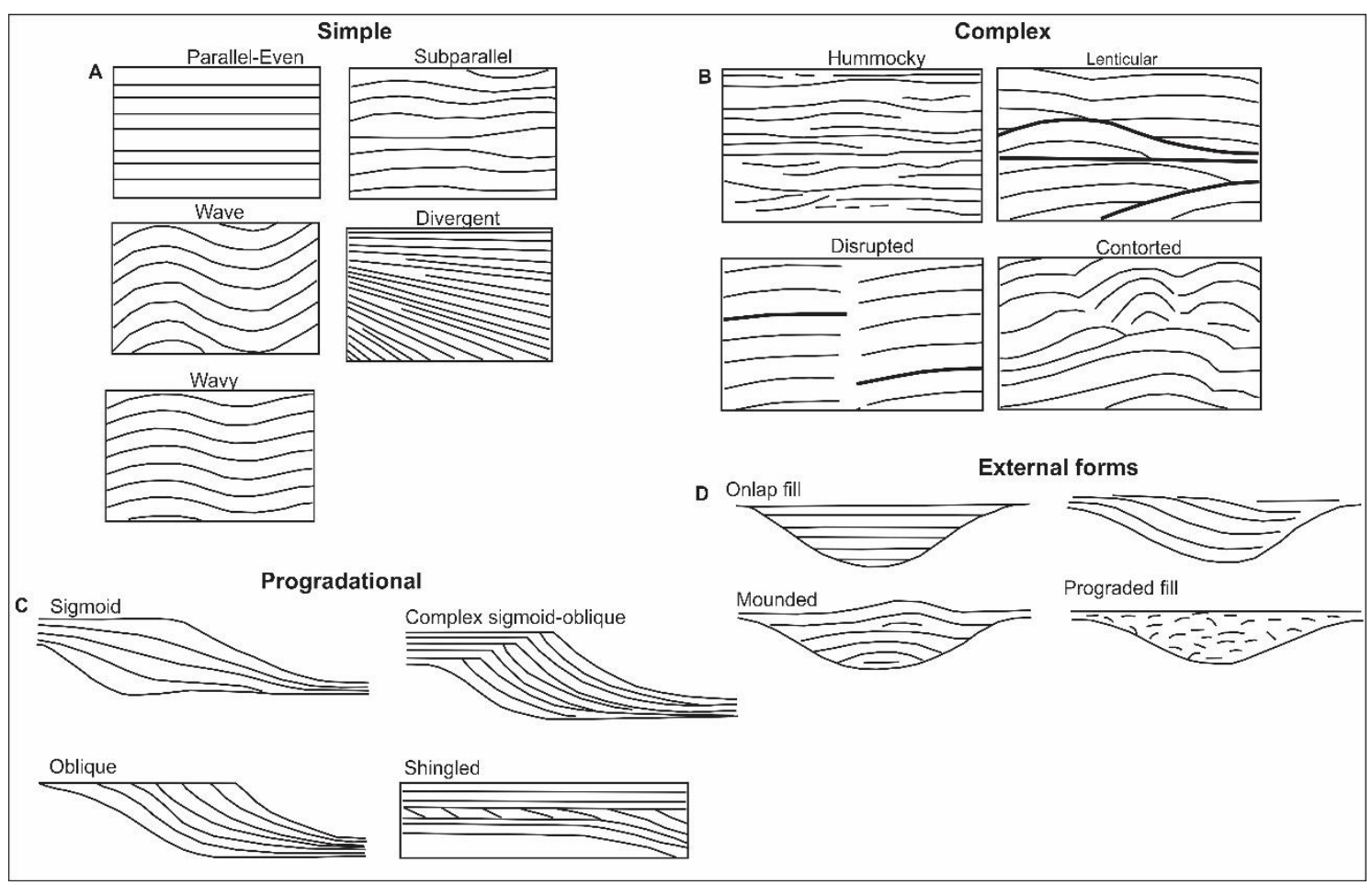

Figure 1.8. Reflection configurations used for seismic facies interpretation in the study area (Mitchum Jr et al., 1977b, Mitchum Jr et al., 1977a) ; (A) Simple seismic reflector geometries; (B) Complex seismic reflector geometries; (C) Different types of progradational clinoforms; (D) Some external forms of troughs and their pattern of fills which are common in seismic facies analysis.

Seismic reflector mapping in northern Zealandia is a challenge as sedimentary and structural barriers affect the continuity of sequence and megasequence boundaries. In addition, the study area is a large region that covers the southern New Caledonia Trough (NCTS), northern New Caledonia Trough (NCTN), southern Lord Howe Rise (LHRS), northern Lord Howe Rise (LHRN), Fairway Basin (FWAY) and Reinga Basin (REIN) (Fig. 1.1). Names of each seismic-stratigraphic unit are defined in each region and locally near boreholes.

Each seismic reflector and unit are assigned a three-part code, for instance, U-NCTN1a (Fig. 3.19) and UB-1510-6 (Fig. 4.11) or UB-NCTN-8 (Fig. 4.23). Part one identifies the bounding surface (UB) - with the prefix U referring to the underlying seismic unit; part two refers to the seismic reflector from north of New Caledonia Trough or IODP site U1510; and part three is used to identify the seismic unit (e.g., 1-9) and sub-unit (e.g., 1a1d). Nomenclature for seismic stratigraphic units (U) and bounding surfaces (UB) is adapted from Bache et al. (2012a, b). 


\subsection{Depth from two-way-travel time}

Two way travel time (TWT) to depth conversion is required to tie TWT seismic reflection interpretation to borehole data (e.g., lithology and biostratigraphy data). Boreholes in northern Zealandia generally do not have check shot data. Depth conversion is accomplished by using synthetic seismograms to model velocity and density variation and hence correlate between core data and reflection seismic data (Stratford et al., 2018, Sutherland, 2019a, Sutherland, 2019b, Sutherland et al., 2018a) (Fig. 1.9, 1.10 \& 1.11).

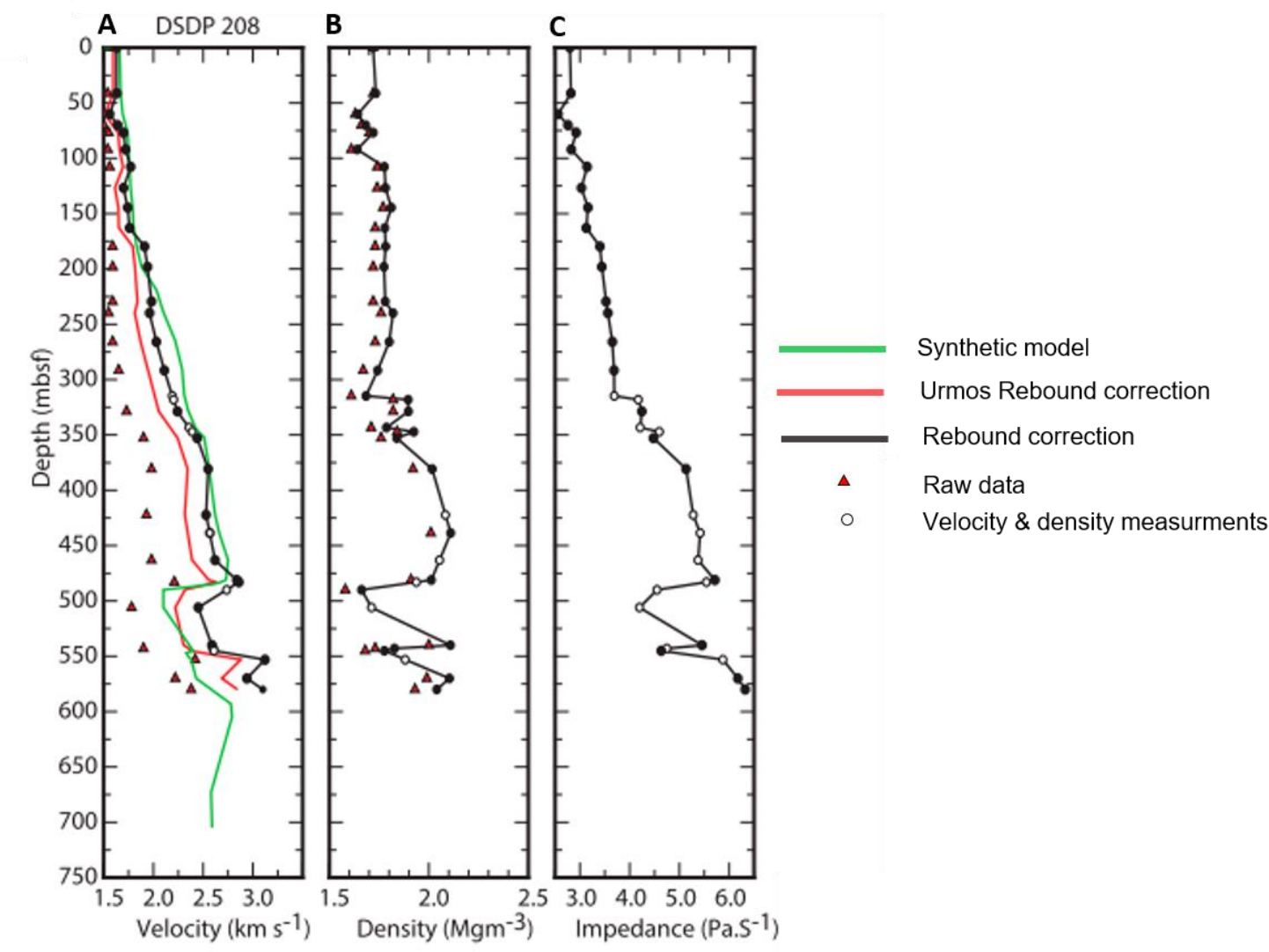

Figure 1.9. Physical property data DSDP 208 (north of Lord Howe Rise) from Stratford et al. (2018) shows (A) raw and drilling core correction (red and black) used to measure velocity and density; (B) velocity and density interpolated from adjacent measurements then plotted as white circles; (C) impedance $(\rho \mathrm{Vp})$. 


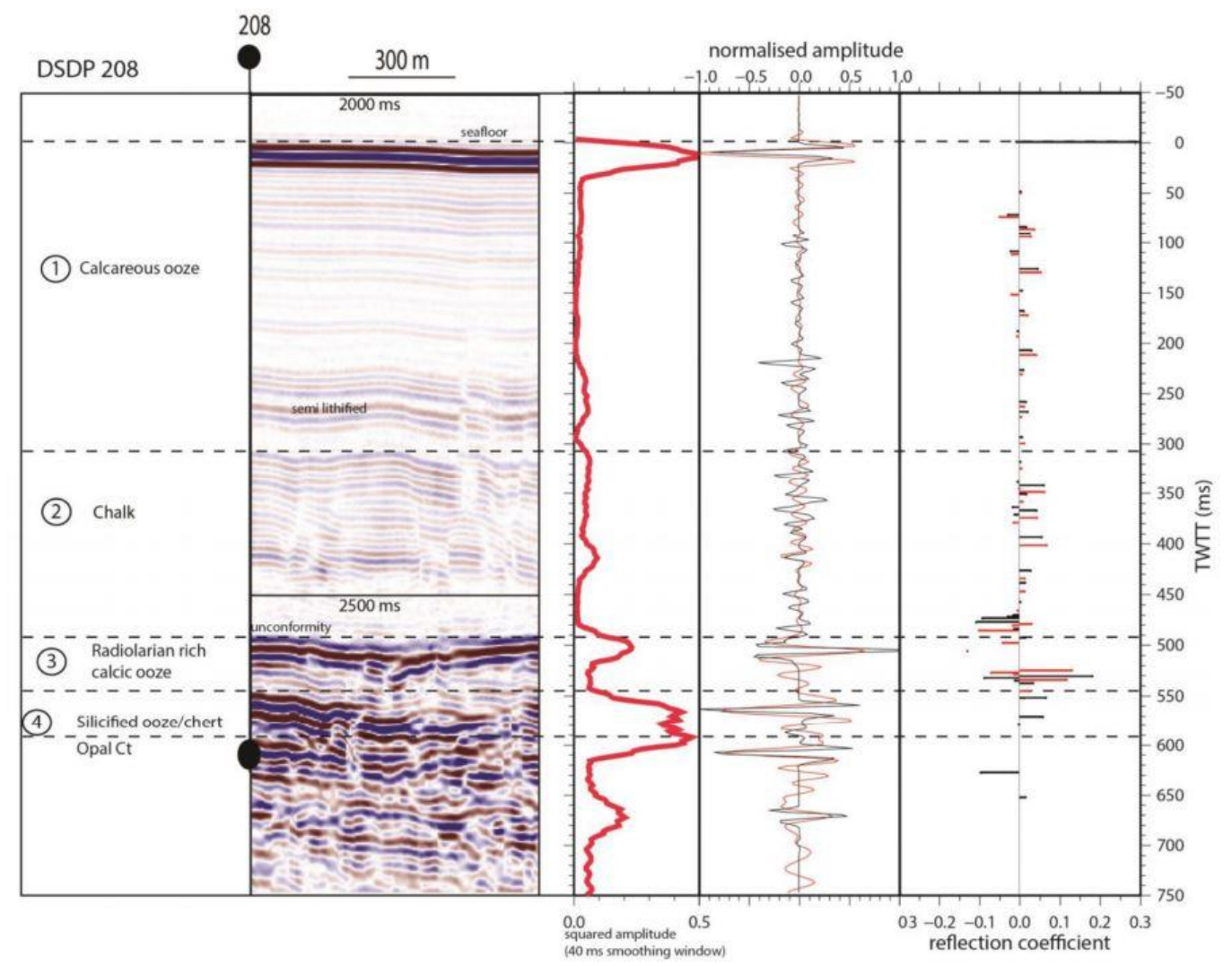

Figure 1.10. Seismic line Ga-302-09 at Site DSDP 208 showing borehole data tie to Site 208 from Stratford et al. (2018). The seafloor reflection indicates a strong positive polarity used to normalise amplitude for synthetic model. A zero point in TWT for data in circles 1-4 is defined by seafloor. There is change in reflectivity at c. $220 \mathrm{~ms}$ TWT related to increase lithification at $300 \mathrm{~ms}$ TWT (chalk). High amplitude negative polarity reflection at $490 \mathrm{~ms}$ TWT is related to Eocone/Oligocene unconformity. Two high positive reflecttions in circle 4 (540 and $580 \mathrm{~ms}$ TWT) are chert and opal-A/CT transition. Normalised amplitude of real (red) and synthetic (black) seismic data and reflection coefficients are also shown. 


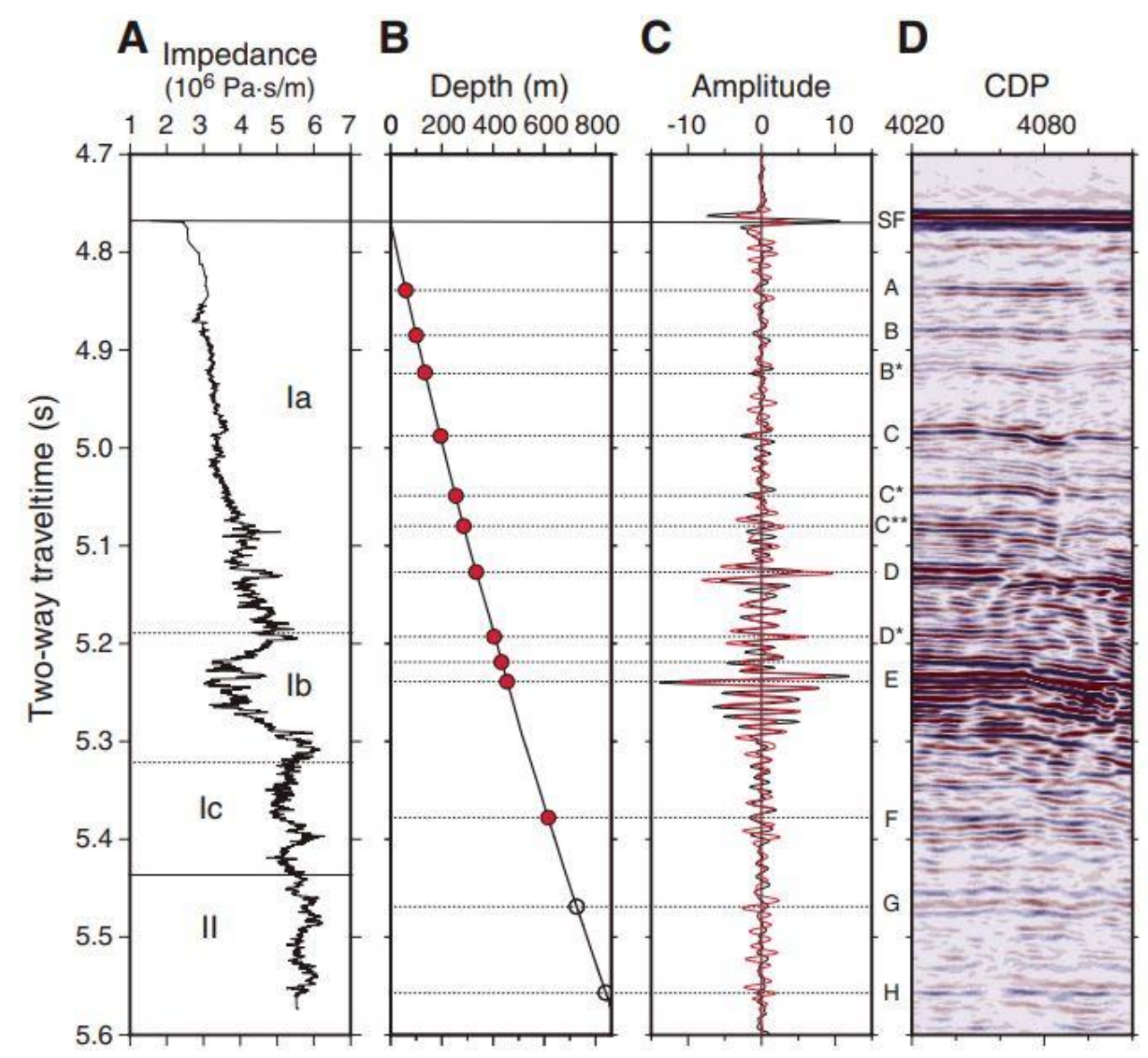

Figure 1.11. Seismic line TAN1409-NCTN-11 at CDP 4020 recorded at Site U1507 shows borehole tie (Sutherland, 2019a, Sutherland, 2019b, Sutherland et al., 2018a). A-B are fit well by the synthetic seismogram. (A) Horizontal line = lithostratigraphic unit boundary, dashed horizontal line $=$ sub-unit boundaries; (B) TWT was calculated from depths below seafloor and numerical solution for two-way time $(t w t)$ with depth $(z)$ is given by $\mathrm{z}=294.43 * \mathrm{twt}^{2}+822.34 * t w t$. Red circles are reflectors correlated in $\mathrm{C}$ and $\mathrm{D}$ and white open circles is not correlated, dashed lines appeared to fit between seismic survey data in D and synthetic trace in C. (C) red synthetic trace, (D) MCS trace data at Line TAN1409-NCTN-11 and A$\mathrm{H}$ labels showing seismic reflectors and seafloor $(\mathrm{SF})$.

The physical property measurements were mostly done on cores. The cores were divided into units based on lithology to do physical measurement (Fig. 1.9, 1.10 \& 1.11) (Stratford et al., 2018, Sutherland, 2019a, Sutherland, 2019b, Sutherland et al., 2018a). $P$-wave velocity and density data obtained from cores used to calculate acoustic impedance, reflection co-efficients and synthetic seismograms (Sutherland, 2019c, Sutherland et al., 2018b, Sutherland, 2019a, Sutherland, 2019b, Stratford et al., 2018). 
Two-way-time depth tie points were selected (Fig. $1.10 \& 1.11$ ) and hence two-way time (twt) was calculated from depth (z) below seafloor (Table 1.2). Acknowledgement is made to Wanda Stratford of GNS Science, who provided and facilitated access to the twt-depth relationships.

Table 1.2. The numerical solution from Stratford et al., (2018), Sutherland et al., (2018) and Sutherland et al., $(219 \mathrm{a}, \mathrm{b}, \mathrm{c})$ that use as a function of depth to derive single two-way-time versus depth relationship.

\begin{tabular}{|c|c|c|c|}
\hline $\begin{array}{l}\text { DSDP } \\
\text { Boreholes }\end{array}$ & $\begin{array}{l}\text { Numerical solution for TWT } \\
\text { (t) with death }(\mathrm{z})\end{array}$ & $\begin{array}{c}\text { IODP } \\
\text { Boreholes }\end{array}$ & $\begin{array}{c}\text { Numerical solution for TWT }(\mathrm{t}) \text { with } \\
\text { death }(\mathrm{z})\end{array}$ \\
\hline 208 & $z=486.55^{\star} t w t^{2}+779.09^{\star} t w t$ & U1506 & $z=120.53^{*} t w t^{2}+846.37^{*} t w t$ \\
\hline 207 & $z=664.28^{\star} t w t^{2}+682.42^{*} t w t$ & U1507 & $z=294.43^{\star} t w t^{2}+822.34^{*} t w t$ \\
\hline 206 & $Z=388.97^{*} t w t^{2}+779.23^{*} t w t$ & U1508 & $z=326.77^{\star} t w t^{2}+781.74^{\star} t w t$ \\
\hline 592 & $z=418.42^{*} t w t^{2}+801.55^{\star} t w t$ & U1510 & $z=319.58^{\star} t w t^{2}+862.35^{\star} t w t$ \\
\hline
\end{tabular}




\section{Geographical and Geological Setting}

Northern Zealandia is a very large area with a boundary frontier location containing possible potential for petroleum accumulation. Discoveries of economically viable oil and gas fields in the Gippsland and Taranaki basins have attracted interests in the region surrounding northern Zealandia (see discussion in chapter 3, section 8.1 \& chapter 5). Northern Zealandia is contained within the Exclusive Economic Zone (EEZ) and Extended Continental Shelf regions of New Zealand, Australia and France (GNS, 2015, Willcox et al., 2001). The remote boundary location will play a key role in any future exploration and development of the region (chapter 5). Hence, I include here some description of northern Zealandia's geographical setting, and the ports, cities and islands that might provide essential infrastructure (Fig. 2.1).

The current oceanography of the region provides valuable insight for mapping and understanding of the Cenozoic sequence more generally (see result in Chapter 4). Variations of ocean currents strongly impact biogenic productivity and hence sediment distribution in the region (chapter 4) (Deacon, 1982, Smith et al., 2013). I provide here some background information on the oceanic system in the region to provide a basis for understanding the significant changes in sedimentation patterns during Neogene time.

The summaries in this section are focused on: human geography (population, cities and ports) in relation to chapter 5 (petroleum analysis and future prospectivity); physical geography (ocean-climate system) in relation to chapter 4 (Cenozoic sedimentation); and tectonic history in relation to chapters 3,4 and 5, because it shaped northern Zealandia and affected all aspects of geological development. 


\subsection{Human geography}

The study area is underlain by the hidden continent Zealandia, and it is $95 \%$ underwater with just a few islands (Mortimer et al., 2017). Hence, I discuss the geography of Australia, New Caledonia, New Zealandia and islands (Norfolk Island, the Lord Howe Island group, and Elizabeth and Middleton reefs), including their population, major cities, and ports. These countries and islands provide access or resources to support research studies or future petroleum exploration and development in the region.

The Australian continent includes the island of Tasmania and numerous smaller islands (Fig. 2.1). Some islands of Zealandia belong to the Australian territories and include the Lord Howe Rise Island Group, Norfolk Island, and Elizabeth and Middleton reefs (Coral Sea Island Territory). The major cities in Australia close to the study area are Brisbane, Sydney, Canberra and Melbourne (Fig. 2.1). Its closest neighbours to the north are New Caledonia, Fiji, Papua New Guinea, Timor-Leste and Indonesia (Fig. 2.1). The population of Australia is about 25 million (Australia Bureau of Statistics, 2019) and Australia has a land area of about 7.692 million $\mathrm{km}^{2}$ (Fig. 2.1).

Lord Howe and Norfolk islands are isolated in the southwest Pacific. Lord Howe Island $\left(31.5^{\circ}\right.$ lat) lies 1,200 km south of New Caledonia, 1,600 km north of New Zealand and $\sim 600 \mathrm{~km}$ east of Australia (Fig. 2.1). Lord Howe Island has an area of $15 \mathrm{~km}^{2}$ and lies in the centre of a $20 \mathrm{~km}$ wide platform. According to the Australia Bureau of Statistics (2018), Lord Howe Island has a population of 400 and there are seven uninhabited islands to the north of the island. Norfolk Island (29 $\left.02^{\prime} \mathrm{S}, 167^{\circ} 57^{\prime} \mathrm{E}\right)$ covers about $35 \mathrm{~km}^{2}$ and has two nearby smaller uninhabited islands Nepean $\left(1 \mathrm{~km}^{2}\right)$ and Phillip $\left(5 \mathrm{~km}^{2}\right)(\mathrm{Nash}$, 2013). It is located about $1700 \mathrm{~km}$ from Sydney and $1100 \mathrm{~km}$ from Auckland. Norfolk Island has a population of about 2,000 (Nash, 2013).

New Zealand is an island country in the southwest of Pacific and has two main landmasses, North Island and South Island. The capital city is Wellington and other cities near the study area are Auckland (North Island) and Nelson (South Island) (Fig. 2.1). The land area is $114,000 \mathrm{~km}^{2}$. New Zealand is located about $2000 \mathrm{~km}$ east of Australia across the Tasman Sea and $1000 \mathrm{~km}$ south of the Pacific island of New Caledonia and Fiji (Fig. 
2.1). The population of New Zealand is about 4.8 million based on United Nation data (2019).

New Caledonia (Nouvelle-Calédonie) is known as a special territory of France and the capital city is Noumea (Fig. 2.1). New Caledonia $\left(20^{\circ} \mathrm{S} \& 22^{\circ} 30 \mathrm{~S}, 164^{\circ} \mathrm{E} \& 167^{\circ} \mathrm{E}\right)$ (Fig. 2.1) covers about $16,900 \mathrm{~km}^{2}$ and is nearly $500 \mathrm{~km}$ long and up to $50 \mathrm{~km}$ wide (Chevillon, 1996). The New Caledonian population is 271,407 according to 2019 census data (ISEE, n.d).

Ports discussed in this section are identified based on relevance for enabling support to any future offshore petroleum exploration across northern Zealandia (Fig. 2.1). Ports are also needed for the transportation of goods and people, and act as a gateway to the southwest Pacific region. There are eight ports in key locations for supply activities to the study area: in Papua New Guinea (PNG), Australia, and New Zealand (Fig. 2.1). The PNG port is close to the capital city of Port Moresby. Other ports are Botany (Sydney) and Brisbane ports located in eastern Australia (Fig. 2.1) and these ports are known as Australia's largest container ports, especially for trade and bulk liquid imports. There are alternative ports close to Port Botany in Sydney, Port Kembla and Newcastle. Lastly, four main ports in New Zealand include Nelson, Wellington, Taranaki, Auckland and Northland ports (Fig. 2.1). Most of the ports in New Zealand link domestic and international shipping services. These ports provide wide channels to supply vessels and landside infrastructure to provide water, fuel, drilling mud, deck equipment, and to support any research study or petroleum exploration in the region. 


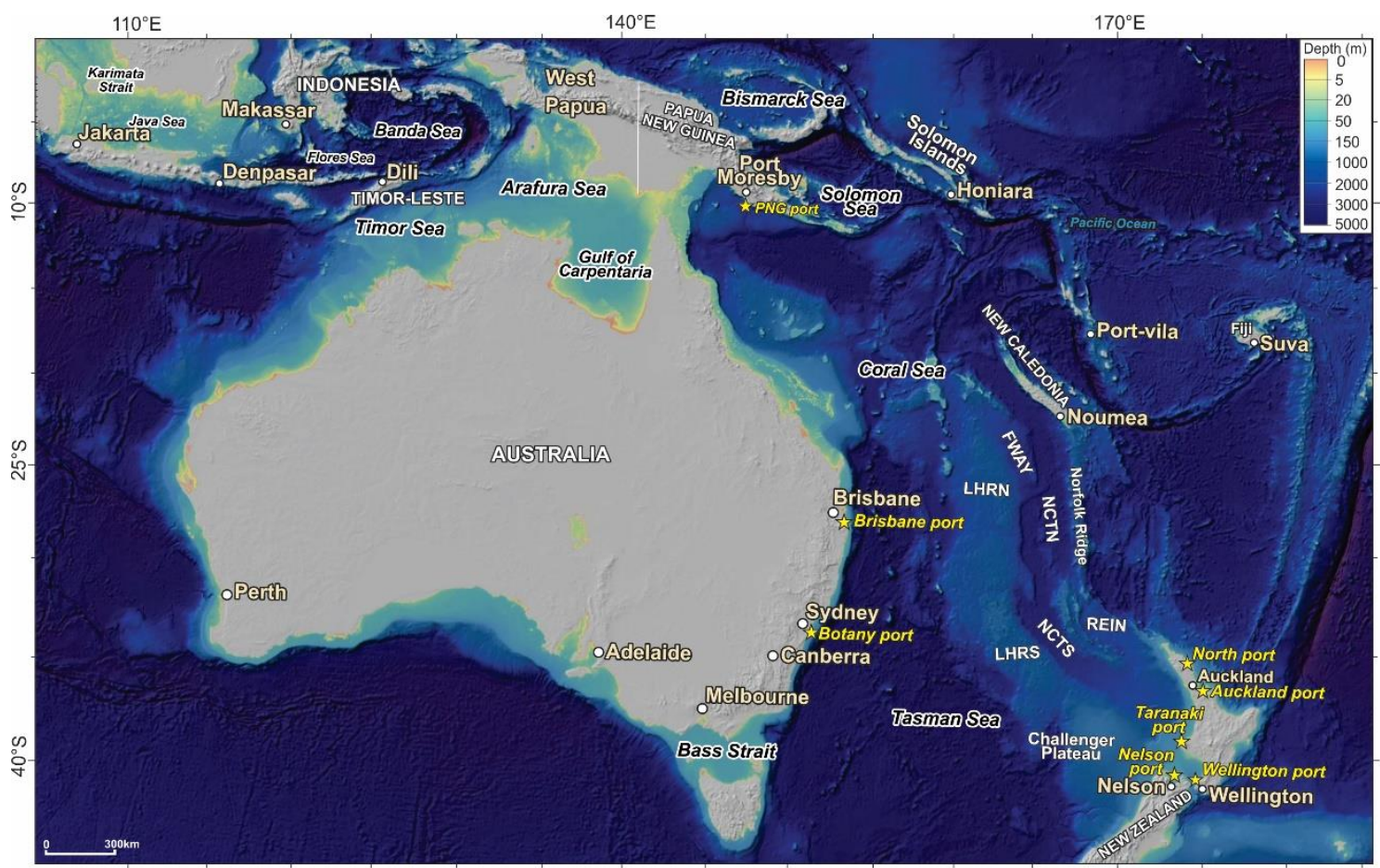

Figure 2.1. Bathymetry map showing the southwest Pacific region with major cities and ports. White circle = major cities; Yellow starts = major ports; LHRN = Northern Lord Howe Rise; LHRS = Southern Lord Howe Rise; FWAY = Fairway Basin; NCTN = Northern New Caledonia Trough; NCTS = Southern New Caledonia Trough and REIN= Reinga Basin.

The southwest Pacific region has relatively low population but Asian countries represent significant markets, and have existing economic and strategic interests in the region (Mediansky, 1987). Relationships and new economic and strategic interests have emerged in this region. Economic development in the Pacific region is relatively low but it is strategically essential for possible petroleum potential and very large area (Lum and Vaughn, 2007). New Zealand, Australia and Asia are known as the fastest growing economic region. The region depends on Australia and New Zealand to support and promote development (e.g. through natural resources and primary production), and to maintain political stability in the region. The local economies of the region rely on Australia and New Zealand, but China is now the largest trading partner with both countries and has been investing in the Pacific Island states. 


\subsection{Physical geography}

The Tasman Sea sector of Zealandia in the southwest Pacific region is a region of about 3,000,000 km² (Sutherland et al., 2012, Mortimer et al., 2017) composed of bathymetric rises and troughs (Fig. $2.1 \& 2.4$ ). The region has water depths between 1000 and $4000 \mathrm{~m}$. The New Caledonia Trough (NCT) is a northwest-oriented bathymetric feature, about $2000 \mathrm{~km}$ long and $250 \mathrm{~km}$ wide with a water depth of 2000-3500 m (Sutherland et al., 2010) (Fig. 2.1). The Lord Howe Rise (LHR) extends about $2800 \mathrm{~km}$ from the central Coral Sea in the tropical north to the Challenger Plateau in the southwest of New Zealand with water depths between 500-2000 m (Standard, 1961, van der Linden, 1970). Adjacent bathymetric features comprise Fairway Basin (FWAY), New Caledonia Trough (NCT), Norfolk Ridge (NR) and Reinga Basin (REIN) lying to the east of Lord Howe Rise. FWAY is $700 \mathrm{~km}$ long and $150 \mathrm{~km}$ wide with a water depth ranging from 500-3000 m (Rouillard et al., 2017). The NR runs between New Caledonia and New Zealandia with a water depths between 0-2000 m (Sutherland et al., 2010). The REIN extends $\sim 500 \mathrm{~km}$ with a water depth ranging from $\sim 1000-2000 \mathrm{~m}$, and shallow water is less than $500 \mathrm{~m}$ (Stagpoole et al., 2009).

I introduce the ocean climate system of the southwest Pacific region in Figures 2.2, 2.3 and 2.4. The main components of the ocean climate system in the region: Australia, the inflow/outflow of ocean currents (South Equatorial Current, East Australia Current \& Antarctic Circumpolar Current), the consequent existence of different water masses (Subtropical Water and Subantarctic Water), and winds. A schematic of the ocean circulation (Fig. 2.2) shows the relationships between water masses, fronts and their distribution. Ocean currents are created by surface winds, temperature and salinity gradients, and tides (Sudre et al., 2013, Durack and Wijffels, 2010, Hill et al., 2008). Ocean currents transport warm water and precipitation from the equator towards the poles and cold water from the poles back to the tropics. This circulation controls primary productivity, pelagic sedimentation and reworking of seafloor sediments by bottom currents. The ocean climate system behaviour responds to changes in Australian climate, the South Equatorial Current (SEC), East Australia Current (EAC), Antarctic Circumpolar Current (ACC), Subtropical Water (STW) and Subantarctic Water (SAW), the Subtropical Front (STF) and wind influences (Fig. $2.2 \& 2.4$ ). 


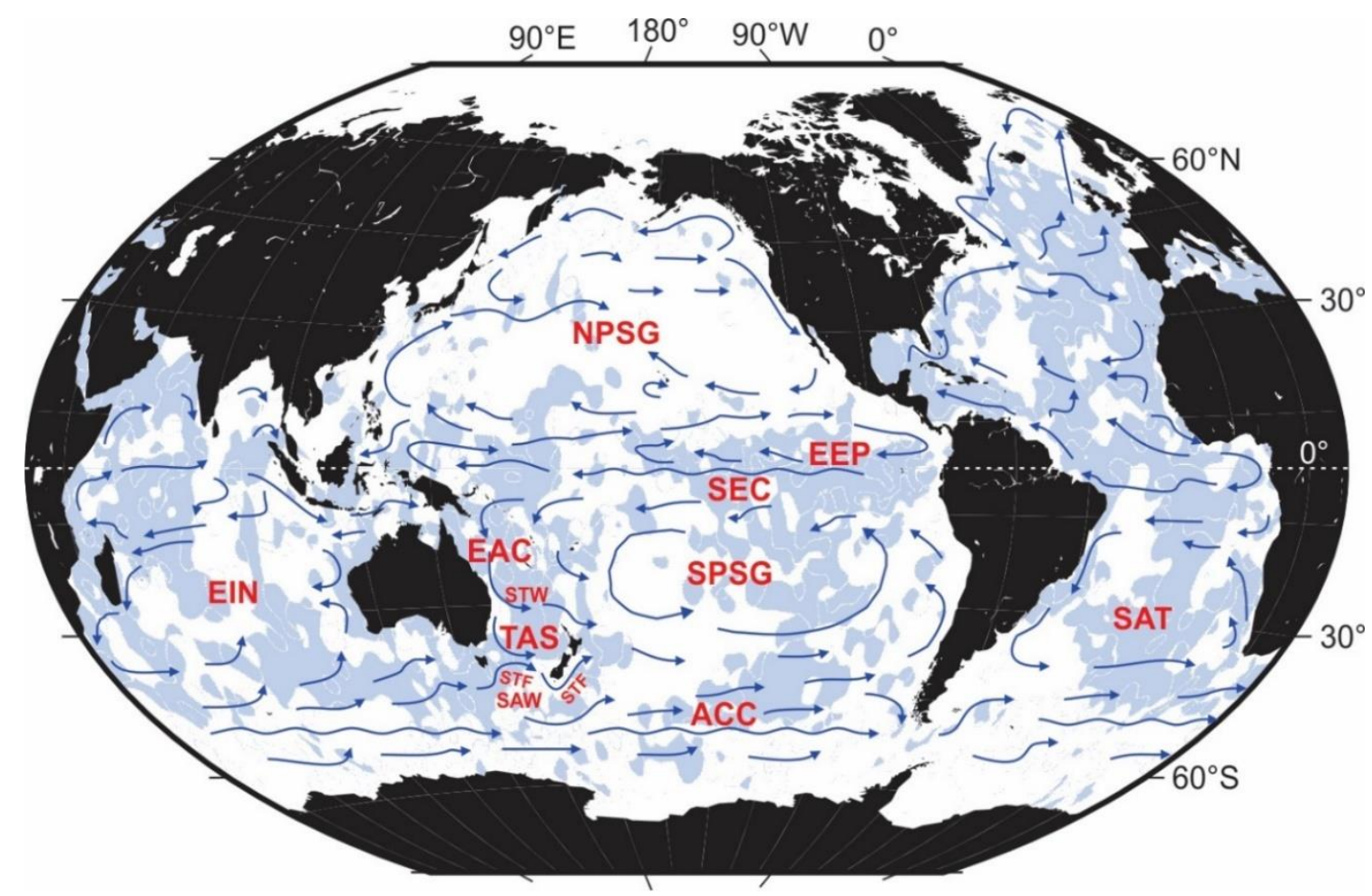

Figure 2.2. Global setting illustrates the major ocean currents that occurred through northern Zealandia. Blue darck arrows = ocean circulation pattern; EIN = East India; SAT = Southern Atlantic; NPSG = North Pacific subtropical gyre; EEP = East Equatorial Pacific; TAS = Tasman Sea. Ocean currents are South Equatorial Current (SEC), East Australia Current (EAC), and Antarctic Circumpolar Current (ACC). Water masses are Subtropical Water (STW), Subantarctic Water (SAW), and Subtropical Front (STF). Modified from Sutherland et al in preparation.

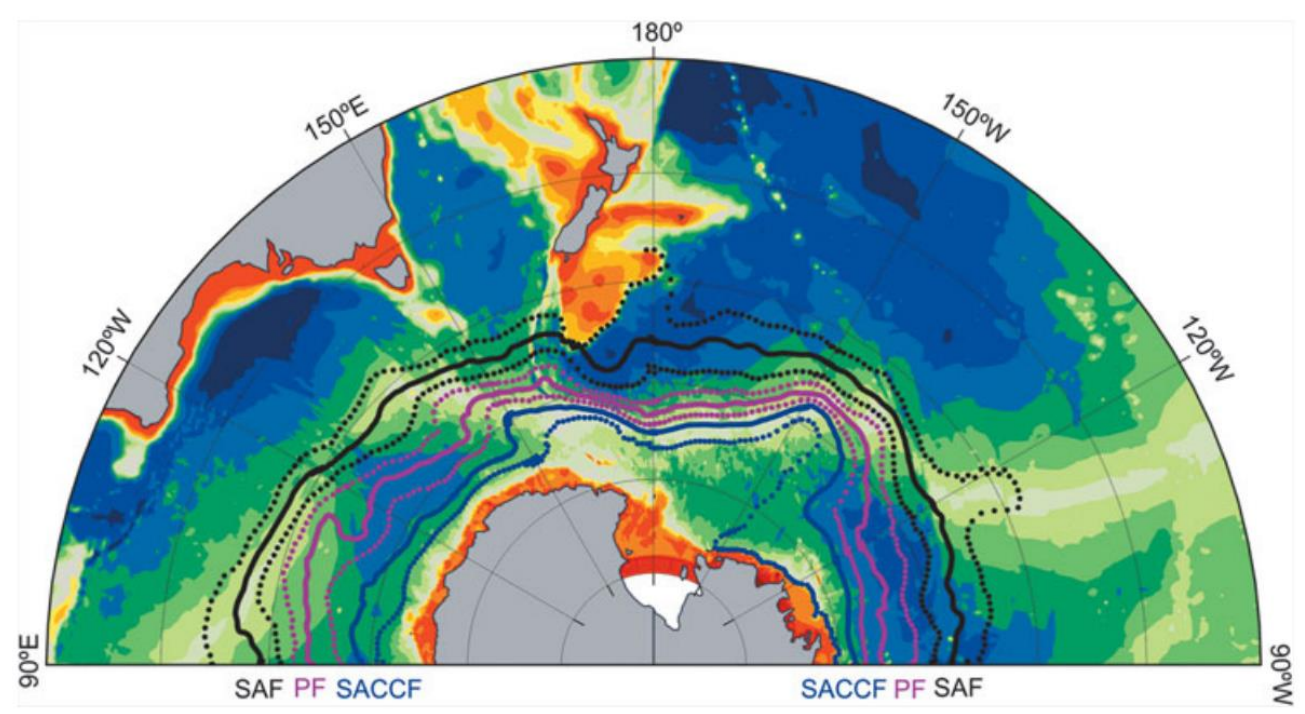

Figure 2.3. Antarctic Circumpolar Current (ACC) fronts from south to north where blue line is Southern ACC Front (SACCF), magenta line is Polar Front (PF) and black line is Subantarctic Front (SAF, black). The background is bathymetry (Sokolov and Rintoul, 2009). 
The Australian climate is controlled by a complex network of currents in the surrounding ocean. Australia is located at the crossroads of oceans and currents (Fig. 2.2). The primary exchange between ocean basins has a significant influence on global ocean circulation and climate, for example, the Indonesian through flow and the Antarctic Circumpolar Current (ACC) (Hu et al., 2015). The combined strength of the ocean circulation affects the area around Indonesia and the north and east of Australia.

The southwest Pacific climate is partly controlled by the broad westward flow of the South Equatorial Current (SEC) that is part of the South Pacific subtropical gyre (SPSG) (Webb, 2000) (Fig. 2.2). The South Pacific subtropical gyre moves water into the Coral Sea (Fig. 2.1) as part of the broad westwards flow of the SEC which meets islands and creates boundary currents that separate into westward jets at their northern and southern tips (Ganachaud et al., 2014). Acceleration of the current occurs southward along the coastal boundary (east Australia) and there separates into north-eastward (Subtropical Counter-Current), eastward (Tasman Front) and southward (Tasman Outflow) components (Fig. 2.4) (Ganachaud et al., 2014, Ganachaud et al., 2007b).

The eastward flow of the East Australian Current (EAC) corresponds with the Tasman Front that divides subtropical and sub-Antarctic surface water masses (Fig. 2.2 \& 2.4) (Mulhearn, 1987). The wind driven EAC is the main western boundary current of the South Pacific Ocean (Ganachaud et al., 2014, Oke and Middleton, 2001). The EAC seems to begin on the west edge of the South Pacific gyre, where it collects nutrient-poor water. Currents flow along the east coast of Australia carrying a large amount of warm tropical water from the equator southward, entraining nutrients along its path. The EAC appears to provide nutrients through the Tasman Front towards New Zealand (Oke and Middleton, 2001). The Tasman Front moves across the Tasman Sea where it interacts with the various ridge systems with part of the flow continuing into the Pacific. The Tasman Front flow has high temporal and spatial variability and influences nutrients around seamounts, reefs, and islands (Przeslawski et al., 2011). Currents bring different types of nutrients to the oceanic waters over the submerged parts of northern Zealandia and affect the productivity and pelagic sedimentation in the region (Kennett et al., 1975). 
The Antarctic Circumpolar Current (ACC) creates three fronts; the Sub-Antarctic Front (SAF), the Polar Front (PF) and the Southern ACC Front (SACCF) (Chiswell et al., 2015) (Fig. 2.3). The SAF affects mostly the New Zealand region and it flows through the Macquarie Ridge and pushes south by the Campbell Plateau (Fig. 2.4) (Sokolov et al., 2006). The SAF moves from the Campbell Plateau to the east into the Pacific Ocean (Morris et al., 2001). The PF appears to be more stable in time than the SAF (Budillon and Rintoul, 2003), but in contrast the SACCF is significantly more stable compared to the PF and SAF (Chiswell et al., 2015).

The Subtropical Front (STF) separates waters in the subtropical gyres from SubAntarctic waters (Orsi et al., 1995) (Fig. 2.2 \& 2.4). The STF region experiences mixing between Subtropical Water (STW) and Sub-Antarctic Water (SAW). This is enclosed by the North STF and South STF (Belkin and Gordon, 1996, Hamilton, 2006, Stanton and Ridgway, 1988, Sutton, 2001, Belkin, 1988). The southern STF is strongly meandering in the Tasman Sea and this may be associated with high mesoscale activity generated from the EAC (Fig. 2.2 \& 2.4) (Hamilton, 2006, Stramma et al., 1995). The STF flows around the Tasman Sea and the southern tip of the South Island of New Zealand before turning north along the Campbell Plateau (Fig. 2.4). The STF in the Tasman Sea moves to a gap in the Macquarie Ridge ( $\left.49^{\circ} \mathrm{S}\right)$ and flows with eddy and meander-like features $\left(50^{\circ} \mathrm{S}\right)$ then continues north across Campbell Plateau (Fig. $\left.2.2 \& 2.4\right)$ (Smith et al., 2013). 


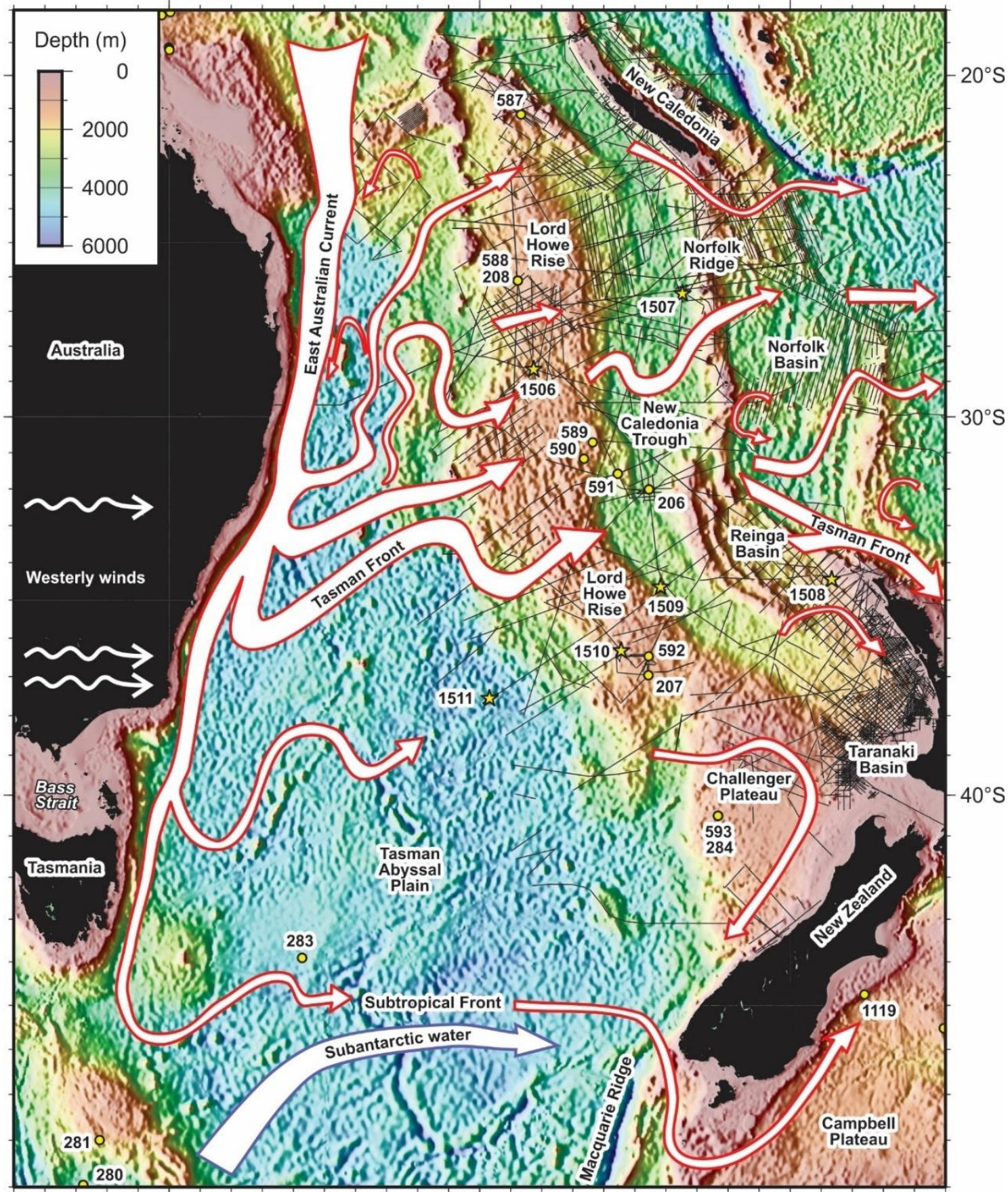

Figure 2.4. Bathymetry of southwest Pacific showing depth shallower than $6000 \mathrm{~m}$ and the main currents. The arrows represent circulation of surface currents around northern Zealandia (principally the East Australia Current). They are driven by west winds in east Australia. Yellow circles = DSDP boreholes; Yellow stars = IODP boreholes. Modified from Sutherland et al., in preparation. 
The southwest Pacific circulation is associated with south-easterly trade winds in the northern part of my study area (Ganachaud et al., 2013, Ganachaud et al., 2014). The wind direction and strength in the southern extra-tropical storm belt comprises southerly winds in the colder and wetter season and strong north-easterly winds and hurricanes during the summer. Hurricanes occur less frequently in a subtropical region, but tropical cyclones can reach as far south as the North Island of New Zealand (Shaw, 1983).

The Tasman Sea is influenced by prevailing westerly winds (Chiswell et al., 2015, Hamilton, 2006). Westerly winds have marked variation in strength with latitude in response to the annual cycle of mean atmospheric pressure across the Tasman Sea throughout the year. The zonal westerly wind increases relate to sea temperature gradients (Mickelson et al., 1991). The zonal westerly wind can deflect the EAC to the east, hence decrease the temperature gradient in the Bass Strait. The EAC determines the strength and direction of wind (Fig. 2.4). Westerly winds carry wet weather to mountain chains, warm weather along the east coasts, and extend for thousands of kilometres upstream of New Zealand. 


\subsection{Tectonic history}

\subsubsection{Introduction}

Geophysical studies done during the 1960s and the 1970s revealed that the Lord Howe Rise may have an underlying continental crustal structure, and marginal basins east of Norfolk Ridge were associated with Cenozoic evolution of Tonga Kermadec subduction (Sutherland et al., 2017, Shor Jr et al., 1971, Karig, 1971). The stratigraphic framework, tectonic structure and history of the region were mapped and confirmed during legs 21, 30 and 90 of the Deep Sea Drilling Project (Burns, 1973a, Burns and Andrews, 1973, Kennett and von der Borch, 1986, Kennett et al., 1985). These previous works, combined with detailed offshore studies and analysis of land area (Bache et al., 2012a, King, 2000a, King and Thrasher, 1996, Bache et al., 2014a, Sutherland et al., 2017), suggest that northern Zealandia experienced four phases: the Gondwana subduction margin (>350 - $100 \mathrm{Ma})$, rifting (100-80 Ma), passive margin (80-50 Ma), and Cenozoic initiation of Tonga-Kermadec subduction (50-0 Ma) (see Fig. 2.5).

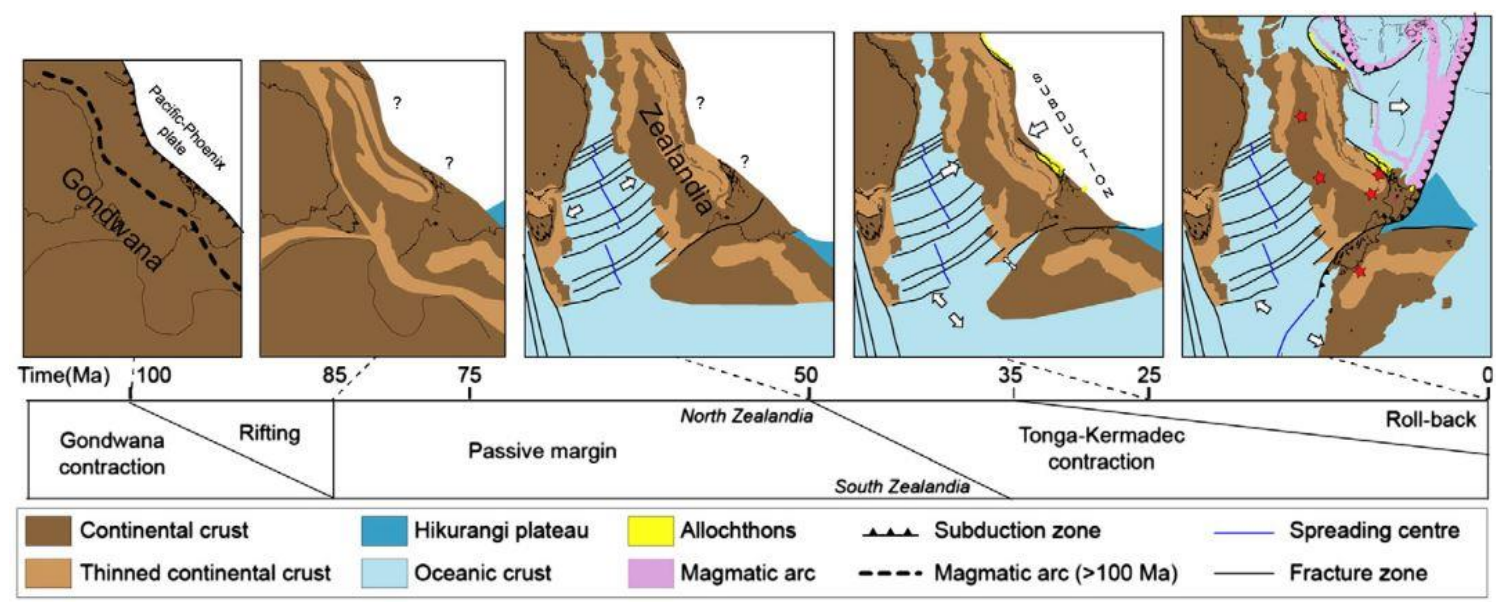

Figure 2.5. Four phases of tectonic evolution of the southwest Pacific (Bache et al., 2014a). The first phase is Triassic to early Cretaceous (>100 Ma) Gondwana margin subduction, the second phase (100-80 Ma) is widespread rifting and extension, the third phase relates to opening of the Tasman Sea, isolating Zealandia, and the last phase is associated with Cenozoic initiation and evolution of Tonga-Kermadec subduction. 


\subsubsection{Basement rock of Zealandia}

The basement rock in northern Zealandia is composed of Palaeozoic to Mesozoic volcanic and sedimentary terranes associated with subduction along the Gondwana margin (Bache et al., 2014b, King, 2000a, King and Thrasher, 1996, Mortimer, 2004). This period of convergence (southwest dipping subduction of the Pacific-Phoenix Plate) led to terrane accretion, uplift and erosion (Laird and Bradshaw, 2004). The basement rock types have been inferred from dredge samples (Tulloch et al., 1991), seismic velocities (Klingelhoefer et al., 2007), gravity and magnetic anomalies (Sutherland, 1999, Wood and Woodward, 2002), and the geology of Australia, New Zealand, New Caledonia, PNG and Timor-Leste.

The Lord Howe Rise may contain rocks referred to as Western Province terranes in New Zealand (Mortimer et al., 1998, Sutherland, 1999, Ballance and Campbell, 1993) or the New England or and Lachlan Fold Belt orogen in Australia (Flood and Aitchison, 1992, Norvick et al., 2001). These rocks are quartzose metasedimentary and granitoids of Paleozoic age and they are known as the eastern edge of Gondwana.

Permian-Mesozoic rocks found in the north of New Zealand are composed of four metasedimentary terranes (Isaac, 1996, Stagpoole et al., 2009, Adams et al., 2002). The Murihiku Terrane is late Permian to late Jurassic volcaniclastic marine sandstone and mudstone (Ballance and Campbell, 1993, Mortimer, 2004). The Dun Mountain-Maitai Terrane comprises a narrow belt of serpentinised ultramafic rocks associated with a linear magmatic anomaly (Junction Magnetic Anomaly) (Sutherland, 1999, Hunt, 1978). The Caples Terrane consists of a metamorphosed sequence of marine volcaniclastic PermianTriassic greywacke and argillite (Mortimer, 2004). The Bay of Islands Terrane is made up of Permian, Triassic and early Jurassic basalt, chert, and limestone which are tectonically intercalated or reworked into Triassic to Jurassic trench and trench-slope sandstones and mudstones (Moore and Smith, 1995).

In Papua New Guinea, Mesozoic sediments were deposited on Palaeozoic continental rocks (Ahmed et al., 2012). The Mesozoic rift succession in the Papuan Basin is similar to hydrocarbon-bearing basins on the northern and western Australian continental margin (Struckmeyer et al., 1990). The Papuan Basin was formed during Triassic-Jurassic (backarc) rifting of the northern margin of Australia (Ahmed et al., 2012). Jurassic strata are 
composed of fine marine shelf clastic sediments deposited during inundation of the margin (Brown et al., 1979). This marine transgression continued into the Early Cretaceous, with deposition of fine clastic sediment followed by shallow-water marine clastic sediment in the Late Cretaceous.

Paleozoic-Mesozoic rocks in Timor-Leste and the Bonaparte Basin in the north of Australia were deposited on north-eastern Gondwana prior to breakup in the Late Jurassic. The Bonaparte Basin was formed by: Palaeozoic extension, Middle to Late Triassic compression, and Jurassic extension that stopped after breakup of Gondwana in the Middle Jurassic (Mory, 1991). The Middle to Late Triassic sequence (Anisian- Norian) found in the Petrel-1 well consists of sandstones and minor amounts of siltstones and shales (Mory, 1991). Northeast-southwest rifting resulted in widespread erosion and a transition from marine to terrestrial deposition. Thermal subsidence occurred in the Early Cretaceous and formed a thick prograding wedge of siliciclastic and carbonate sediment. The east Gondwana megasequence in Timor-Leste ranges from the Permian to Middle Jurassic (Haig and McCartain, 2007, Haig et al., 2019), and was deposited prior to final break-up of north-eastern Gondwana at 155 Ma. Timor Island contains Gondwana Jurassic carbonate-platform facies and shelf facies overlain by Cretaceous deep-water pelagic deposits (Haig et al., 2019).

Mesozoic sediments are found on the Norfolk Ridge. Magnetic anomalies and one dredge sample from the West Norfolk Ridge suggest a magmatic arc of late Palaeozoic and Mesozoic age underlies the southern New Caledonia Trough (Mortimer et al. 1998; Sutherland, 1999). They formed along the active margin of Gondwana. The Norfolk Ridge System is identified as having Mesozoic forearc accretionary rocks that formed at the convergent margin of Gondwana (Adams, Cluzel, \& Griffin, 2009; Cluzel et al., 2012; N Mortimer, 2004). 


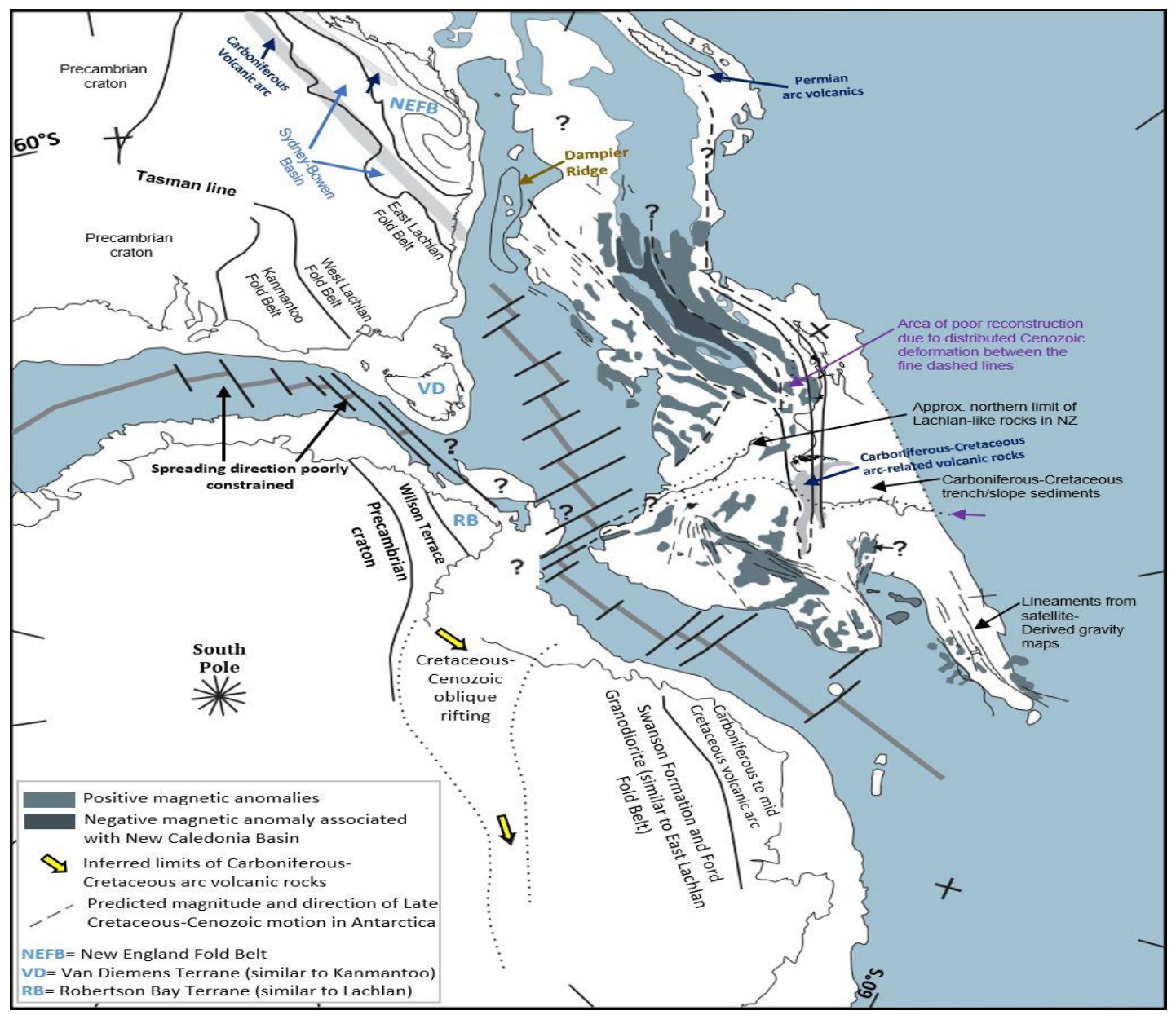

Figure 2.6. Tectonic reconstruction of the southwest Pacific region showing the configuration of rifting during the Late Cretaceous (chron 33; $74 \mathrm{Ma}$ ). The Zealandia continental fragment was rifted from the Gondwana supercontinent during this time following by a long period of subduction (Sutherland, 1999). 

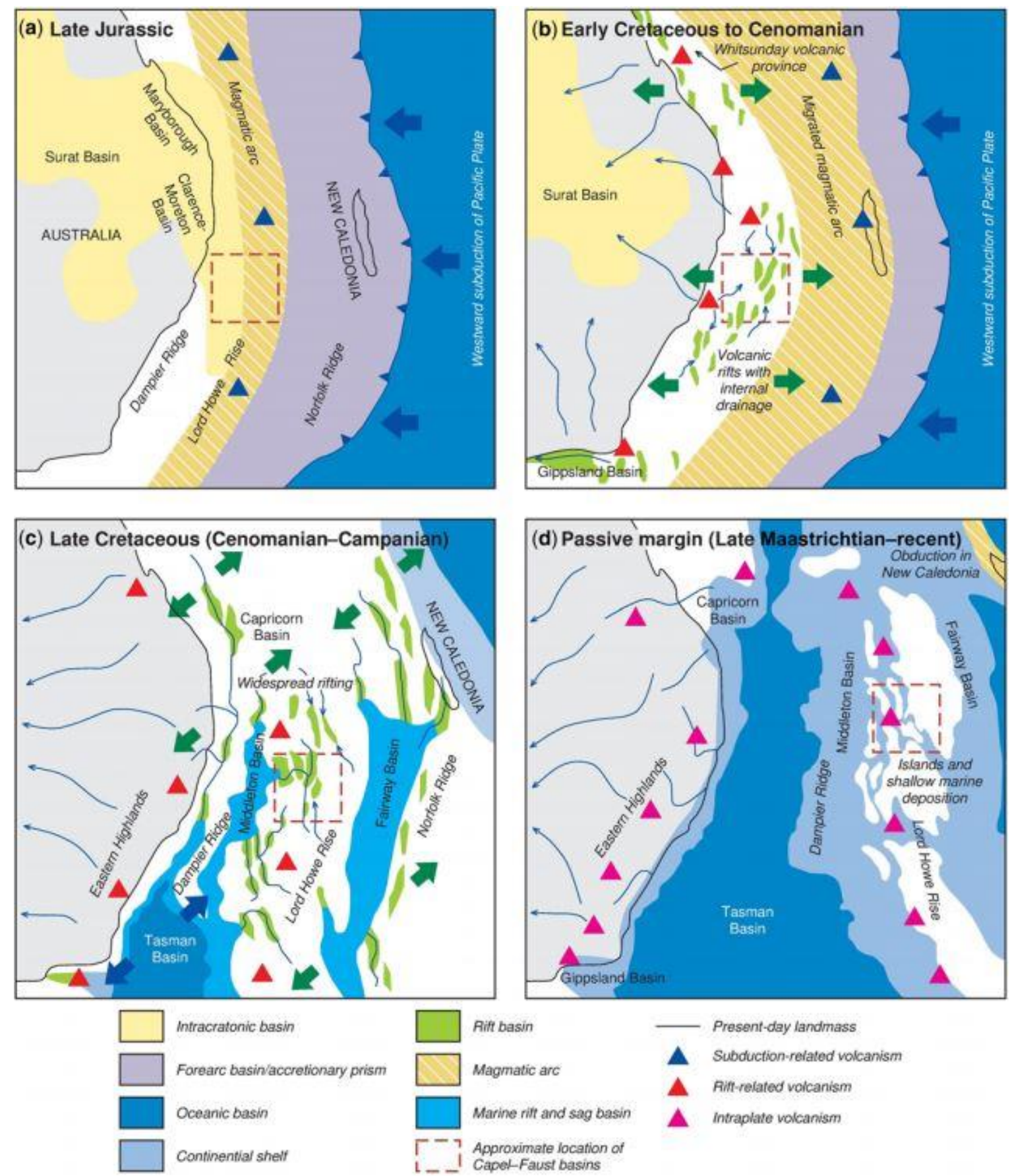

Figure 2.7. Mesozoic - Cenozoic break-up of the eastern Gondwana margin from (Higgins et al., 2014); (a) pre-Cretaceous subduction margin; (b) early rifting or syn-rift 1; (c) late rifting or syn-rift 2; (d) postrift sag and drape. 


\subsubsection{Cretaceous rifting}

During the Cretaceous, Zealandia separated from eastern Australia and Antarctica (Exon et al., 2007, Gaina et al., 1998). Subduction terminated during the Late Cretaceous ( 105-100 Ma) followed by widespread rifting and extension (Matthews et al., 2012, Davy et al., 2008). This was preceded by widespread magmatic activity with variable calc-alkaline and adakitic rock chemistry (Tulloch et al., 2009, Mortimer et al., 1999, Cluzel et al., 2010, Higgins et al., 2011). Marginal breakup moved eastward from 130-95 Ma in eastern Australia (Fig. 2.7) to about 105-80 Ma in New Zealand (Cluzel et al., 2010, Davy et al., 2008).

Widespread rifting across northern Zealandia resulted in formation of grabens and half-grabens during the Late Cretaceous (Fig. 2.6) (Uruski and Wood, 1991, Collot et al., 2009, Strogen et al., 2017, King and Thrasher, 1996). These extensional basins are recognised in seismic reflection data at the base of the southern New Caledonia Trough (Collot et al., 2009, Strogen et al., 2017, Uruski and Wood, 1991), the Reinga Basin (Bache et al., 2012a) and the Lord Howe Rise (Higgins et al., 2015). They are inferred to have a coal-rich succession overlain by transgressive marine sandstone and mudstone, similar to that observed in the Taranaki Basin (King and Thrasher, 1996). This stratigraphic motif underpins the petroleum system in New Zealand and eastern Australia (Gippsland and the Taranaki regions) (King and Thrasher, 1996). Widespread rifting stopped at $\sim 83 \mathrm{Ma}$, in northern Zealandia (Mortimer et al., 2014, Strogen et al., 2017) which led to the subsequent transition to passive margin conditions which were synchronous with the onset of seafloor spreading in the Tasman Sea.

\subsubsection{Cretaceous and Paleogene passive margin}

The opening of the Tasman Sea and the end of rifting led to development of passive margins surrounding eastern Australia, New Caledonia and New Zealand (Ballance, 1993, Cluzel et al., 2010). Magnetic anomalies show that seafloor spreading occurred from the Late Cretaceous to early Cenozoic (Hayes and Ringis, 1973, Weissel and Hayes, 1977). The earliest seafloor spreading may have occurred before 83 Ma east of Tasmania (Hayes and Ringis, 1973) while marginal seafloor spreading occurred at 83-79 Ma along the western edge of Lord Howe Rise (Gaina et al., 1998, Sutherland, 1999). 
Northern Zealandia experienced passive tectonic subsidence after Cretaceous extension terminated, resulting in marine transgression and widespread deposition of terrestrial to shallow marine sands and coal (Baur et al., 2014, King and Thrasher, 1996, King, 2000a, Laird and Bradshaw, 2004, Herzer et al., 1997, Uruski and Warburton, 2010, Bache et al., 2012a). Marine sediments sampled at DSDP sites 206, 207 and 208 indicate flooding of lower-lying ridges surrounding New Caledonia Trough during Cretaceous time (Burns and Andrews, 1973, Burns et al., 1973a, Burns et al., 1973b).

The history of seafloor spreading in the Tasman Sea is inferred from magnetic anomalies (Hayes and Ringis, 1973, Weissel and Hayes, 1977). Royer and Rollet (1997) suggest that seafloor spreading may have occurred at $~ 83$ Ma east of Tasmania, but Gaina et al. (1998) and Sutherland (1999) suggest that marginal seafloor along the western edge of the Lord Howe Rise may have formed during 83-79 Ma.

The end of Tasman seafloor spreading was at about 53-52 Ma (Gaina et al., 1998). Passive subsidence of Lord Howe Rise resulted in a progression from coastal-marine and estuarine settings to shelf and bathyal settings, as indicated by benthic foraminifera found in DSDP 208 and 207 boreholes (Burns and Andrews, 1973, Burns et al., 1973a, Burns et al., 1973b). Based on fossils in dredged mudstone, it appears that Reinga Basin experienced deep-water bathyal conditions during the Palaeocene time, and dredged Palaeocene mudstone sampled from eastern Lord Howe Rise shows that a low-energy marine bathyal environment occurred in late Palaeocene (59-56 Ma) (Browne et al., 2016). Transgression occurred from north and west to south and east along areas of Taranaki and the southern New Caledonia Trough experiencing a bathyal environment at 56 Ma (King and Thrasher, 1996, Strogen et al., 2017).

\subsubsection{Eocene Tonga-Kermadec subduction}

Wide tectonic changes throughout the Pacific and Indian Ocean occurred during the Eocene (53-43 Ma) (Sutherland et al., 2017). Pacific plate motion dramatically changed as new subduction zones formed in the western Pacific, resulting in the Emperor-Hawaii seamount chain bend (Steinberger et al., 2004). During Middle and Late Eocene times, New Caledonia experienced deformation, exhumation, and emplacement of ultra-mafic, mafic, and sedimentary allochthons (Cluzel et al., 2001, Baldwin et al., 2007, Aitchison 
et al., 1995). In New Zealand, regional deformation and emplacement of allochthons was later than in New Caledonia and the Norfolk Ridge System, and occurred during the Late Oligocene and Early Miocene (30-20 Ma) (Bache et al., 2012a, Herzer et al., 1997, Stagpoole and Nicol, 2008).

Seismic-reflection interpretation and rock sample studies (Sutherland et al., 2017) reveal that Eocene Tonga-Kermadec subduction initiation was associated with compressional plate failure after 53-48 Ma and until 37-34 Ma in northern Zealandia and eastern Australia. Folding, uplift and reverse faulting was observed in the Lord Howe Rise and Reinga Basin (Orr et al., 2020, Sutherland et al., 2020, Bache et al., 2012a, Sutherland, 2019c, Sutherland, 2019b). The northern Lord Howe Rise at IODP Site 1506 shows uplift to sea level at $50 \mathrm{Ma}$, and at Site 1510 an uplift between 41 and $32 \mathrm{Ma}$ in the south was confirmed (Sutherland, 2019b, Sutherland et al., 2020). Orr et al. (2020) identified that the Reinga Basin experienced compression and reverse faulting at 39-43 Ma resulting in Eocene and older strata along the northeastern basin margin and in western New Zealand. Reverse faulting termination was determined from undeformed bioclastic limestone (subdided $>1 \mathrm{~km}$ since 36-30 Ma), and syn-tectonic deposits dated at 56-43 Ma (Orr et al., 2020, Sutherland et al., 2017).

From the Oligocene to present day, subduction zone roll-back has formed back-arc basins (Loyalty, Norfolk, Fiji, Havre and Lau) and arc ridges (Loyalty, Three Kings, LauColville, Tonga-Kermadec and Vanuatu) (Herzer et al., 2009, Herzer and Mascle, 1996, Schellart et al., 2006, Mortimer et al., 2007). There are active arcs east of the Norfolk Ridge system that may include older Cenozoic arc rocks. The back-arc region has isolated the submerged continental part of the Tasman Frontier from Cenozoic subduction-related deformation and volcanism, but sediment supply in southern New Caledonia Trough is sourced from the active plate boundary through New Zealand. 


\section{Synthesis of Regional Seismic Stratigraphy}

\subsection{Introduction}

This chapter reviews, reanalyses and updates the regional Cretaceous-Cenozoic stratigraphy of northern Zealandia. I have reanalysed the seismic data, approximately $70 \%$ of lines, and identified horizons (Fig. 3.1). Seismic reflection, borehole data, and published works underpin my analysis (Auzende et al., 2000b, Bache et al., 2014a, Bache et al., 2012a, Burns, 1973a, Burns and Andrews, 1973, Collot et al., 2009, Exon et al., 2007, Exon et al., 2004, Hashimoto et al., 2009, Hashimoto et al., 2008, Kennett and von der Borch, 1986, Lafoy et al., 2005, Rouillard et al., 2014, Sutherland, 2019b, Sutherland, 2019c, Sutherland et al., 2017, Sutherland et al., 2010, Sutherland et al., 2018a, Rouillard et al., 2015, Etienne et al., 2018). I mapped the stratigraphy locally in each sub-region (Fig. 1.2), and then made regional correlations (discussion provided in each section of this chapter and chapter 5).

Bache et al. (2014) defined the seismic-stratigraphic architecture of northern Zealandia into three megasequences U3, U2, and U1 (Fig. 3.2). U3 is the deepest section. It is associated with the long-lived eastern Gondwana active margin before the Late Cretaceous (King and Thrasher, 1996, Mortimer, 2004, Mortimer et al., 2017). U2 is an extensional syn-rift to post-rift margin that ranges from Late Cretaceous to Eocene, involving detritus (syn-rift, subunit $\mathrm{U} 2 \mathrm{~b}$ ) that originated from subaerial erosion of East Gondwana. U2a lies on top of $\mathrm{U} 2 \mathrm{~b}$ and is composed of transgressive marine sediments that were deposited during post-rift thermal subsidence. Finally, U1 deposition was influenced by compressive or passive regimes since Eocene inception and development of Tonga-Kermadec subduction. This stratigraphic framework is reviewed for data from northern Lord Howe Rise (LHRN), southern Lord Howe Rise (LHRS), northern New Caledonia Trough (NCTN), southern New Caledonia Trough (NCTS), Fairway (FWAY) and Reinga (REIN) basins (Fig. $1.1 \& 1.2$ ).

Bache et al. (2014) identified two unconformities (RU2 and RU1) that separated the three megasequences (Fig. 3.2). RU2 is the boundary between $\mathrm{U} 3$ and $\mathrm{U} 2$ with truncation of U3 strata, and U2 onlaps U3. RU1 is the boundary between $\mathrm{U} 2$ and $\mathrm{U} 1$ and corresponds 
to a regional Paleogene hiatus on ridges, and high local rates of deposition in New Caledonia Trough and Reinga Basin (Bache et al., 2014a, Bache et al., 2012a).

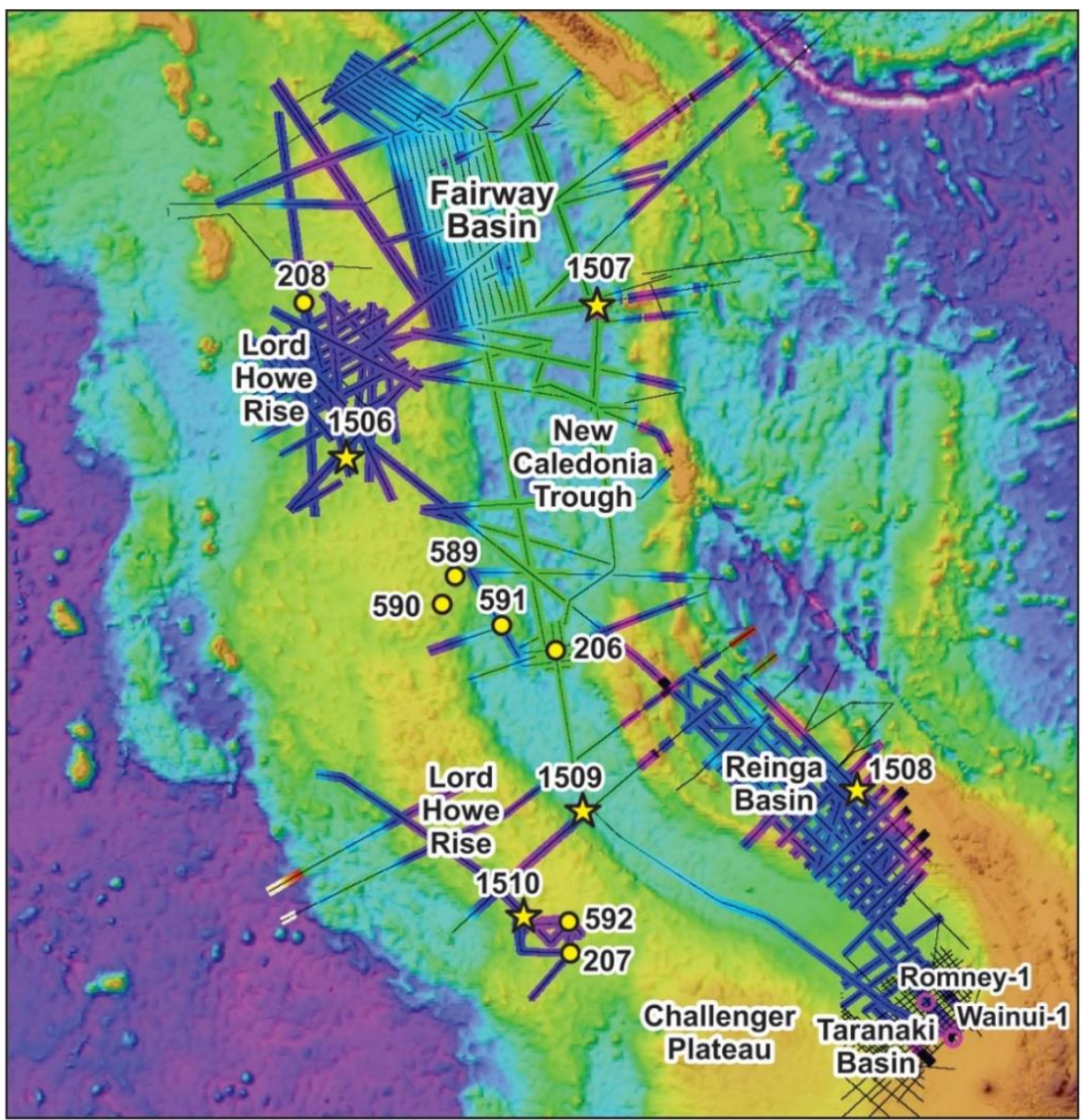

Figure 3.1 Seabed ribbon of the region showing where key horizons were identified. 


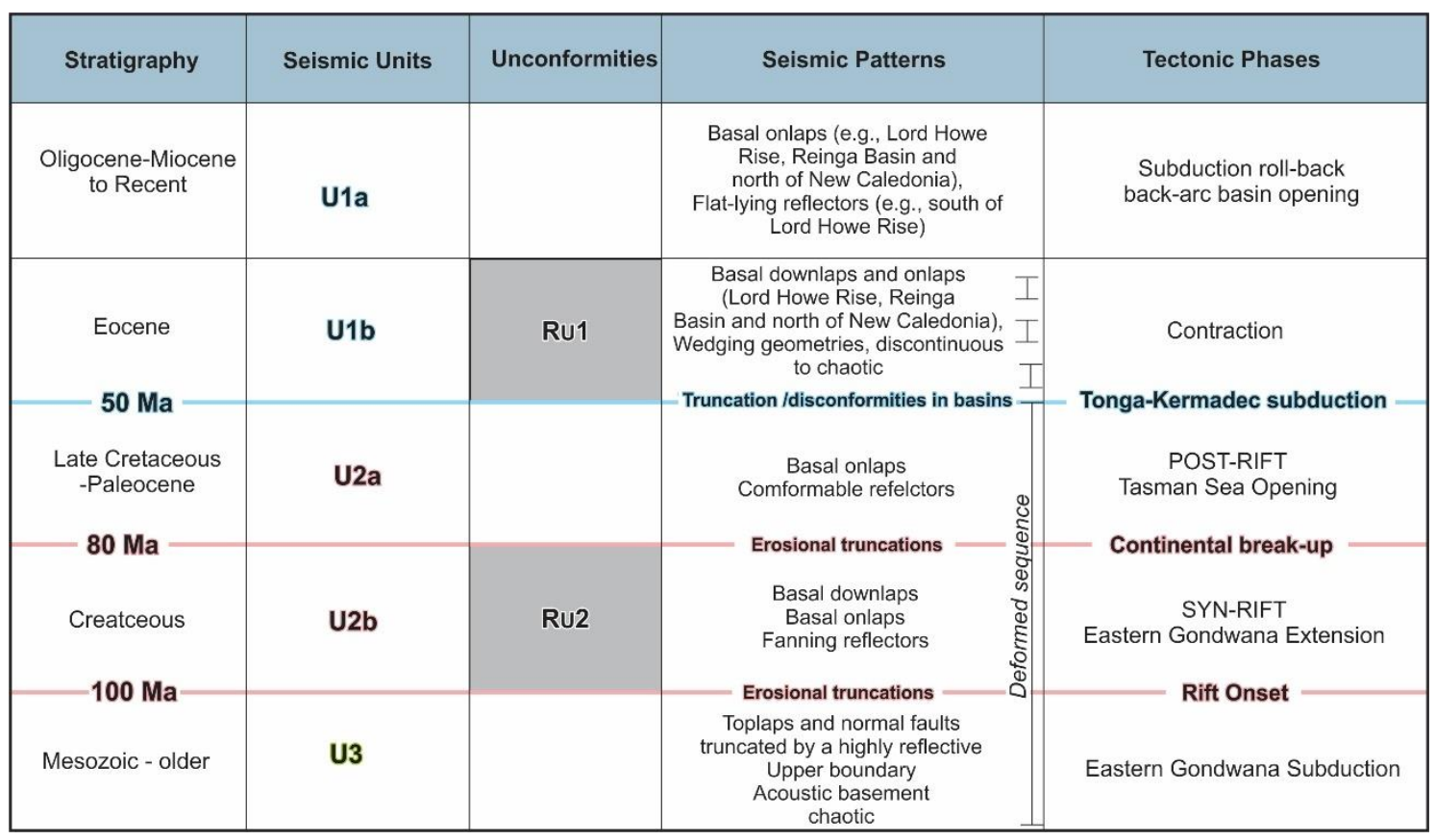

Figure 3.2 Stratigraphic framework adapted from (Bache et al., 2014a, Bache et al., 2012a, Etienne et al., 2018, Rouillard et al., 2017): U3 (eastern Gondwana active margin), U2b (Late Cretaceous syn-rift); U2a (Late Cretaceous to Palaeocene post-rift); U1b (Eocene compression); U1a (subduction inception and Oligocene to Neogene roll-back).

\subsection{Southern Lord Howe Rise (LHRS)}

Previous interpretations (Bache et al., 2014a, Sutherland et al., 2017) of the seismic stratigraphy of southern Lord Howe Rise (LHRS) identified a series of seismicstratigraphic units (Table 3.1 \& Fig. 3.3) related to tectonically-driven basin filling phases (Fig. 3.3). I mapped seismic stratigraphic units of LHRS based on broad correlation to horizons of Bache et al. (2012) and adoption and modification of their nomenclature (see Table. 3.1). LHRS seismic stratigraphy is divided into three units: U-LHRS-1 (U1a \& U1b), U-LHRS-2 (U2a \& U2b) and U-LHRS-3 (Table $3.1 \&$ Fig. 3.3). 
Table 3.1. LHRS Seismic unit characteristics.

\begin{tabular}{|c|c|c|c|}
\hline $\begin{array}{c}\text { Seismic } \\
\text { Units }\end{array}$ & Seismic pattern \& key features & Previously named & References \\
\hline U-LHRS-1a & $\begin{array}{l}\text { - Continuous moderate-amplitude } \\
\text { reflectors with some complex } \\
\text { internal bedforms } \\
\text { - Flay in some place } \\
\text { - } \quad \text { Continuous reflectors with polygonal } \\
\text { faults, channels at base of U1a } \\
\text { - Onlap }\end{array}$ & $\begin{array}{l}\text { Zealandia U1a; Unit } \\
\text { 1a (Sutherland et al., } \\
\text { 2017); Zealandia-1a } \\
\text { (Bache et al., 2014a) }\end{array}$ & \multirow{5}{*}{$\begin{array}{l}\text { (Sutherland } \\
\text { et al., 2017, } \\
\text { Bache et } \\
\text { al., 2014a, } \\
\text { Sutherland, } \\
\text { 2019b, } \\
\text { Sutherland } \\
\text { et al., } \\
\text { 2018a) }\end{array}$} \\
\hline U-LHRS-1b & $\begin{array}{l}\text { - Flat erosion surface incised by } \\
\text { channels } \\
\text { - Continuous reflectors with erosional } \\
\text { channels and fanning or onlap next } \\
\text { to fault or folds } \\
\text { - Fanning growth strata } \\
\text { - Volcano sits on unconformity } \\
\text { - Syn-tectonic }\end{array}$ & $\begin{array}{c}\text { Zealandia U1b } \\
\text { (Bache et al., 2014); } \\
\text { Unit 2b (Sutherland } \\
\text { et al., 2017); } \\
\text { Zealandia-1b (Bache } \\
\text { et al., 2014a) }\end{array}$ & \\
\hline U-LHRS-2a & $\begin{array}{ll}\text { - } & \text { Reverse faulting } \\
\text { - } & \text { deformation } \\
\text { - } & \text { Locally folded }\end{array}$ & $\begin{array}{l}\text { Zealandia U2a; Unit } \\
\text { 2a (Sutherland et al., } \\
\text { 2017); Zealandia } \\
\text { U2a (Bache et al., } \\
\text { 2014a) }\end{array}$ & \\
\hline U-LHRS-2b & $\begin{array}{l}\text { - } \text { Parallel, fanning reflectors } \\
\text { - } \quad \text { Uruncation } \\
\text { - Unconformity unit \& normal faulting }\end{array}$ & $\begin{array}{l}\text { Zealandia U2b; Unit } \\
\text { 2b (Sutherland et al., } \\
\text { 2017); Zealandia-2b } \\
\text { (Bache et al., 2014a) }\end{array}$ & \\
\hline U-LHRS-3 & $\begin{array}{ll}\text { - } & \text { Moderate to low amplitude } \\
\text { discontinuous to chaotic reflectors a } \\
\text { - folded } \\
\text { - Truncation }\end{array}$ & $\begin{array}{l}\text { Zealandia U3; Unit } \\
\text { 2b (Sutherland et al., } \\
\text { 2017); Zealandia-2b } \\
\text { (Bache et al., 2014a) }\end{array}$ & \\
\hline
\end{tabular}

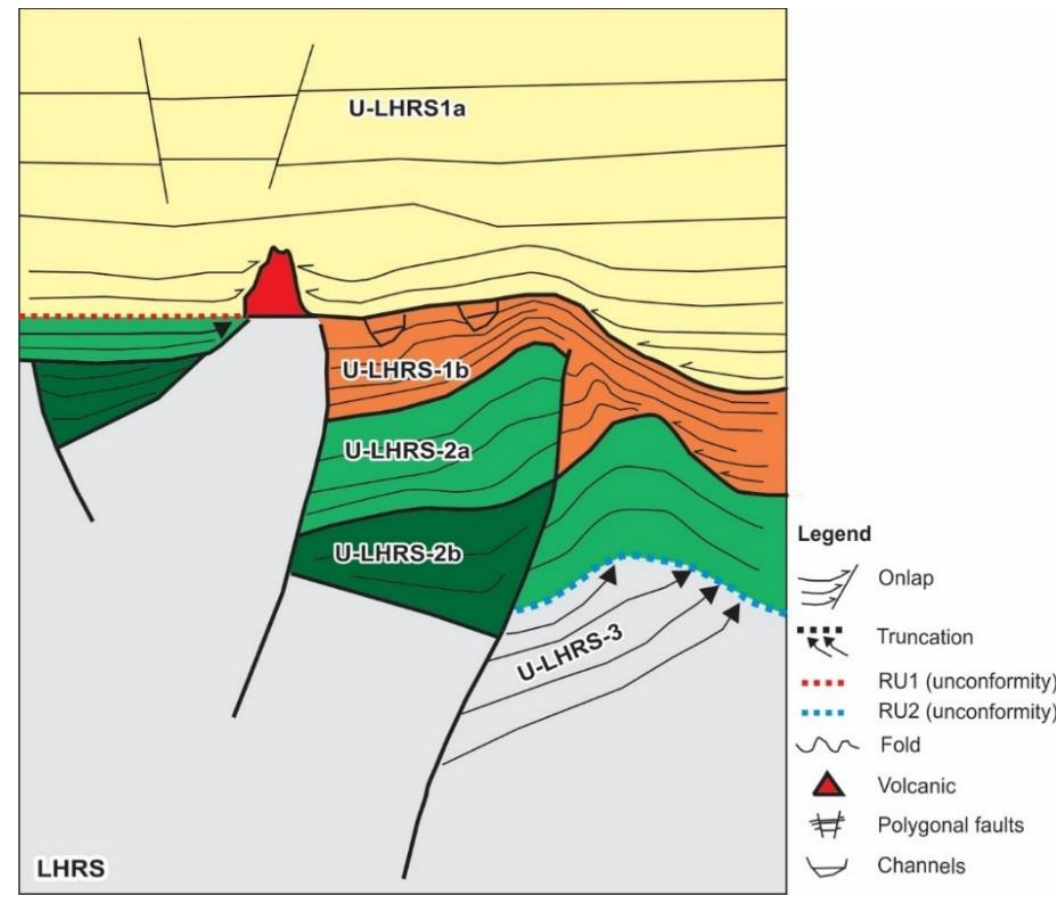

Figure 3.3. Seismic stratigraphy cartoon for southern Lord Howe Rise (LHRS). This seismic stratigraphy cartoon is based on TAN1409-LHRS-16 and 114-06. 


\subsubsection{U-LHRS-3}

U-LHRS-3 contains moderate to low amplitude discontinuous reflectors that are folded and truncated by a prominent unconformity (RU2) southwest of Site U592 (Fig. $3.3 \& 3.4$ ) (Sutherland et al., 2010). RU2 is concordant with U-LHRS-2a reflectors above (Fig. 3.4, Table 3.1) but is itself folded (Bache et al., 2014b, Sutherland et al., 2010). A similar architecture is observed in Northland and Reinga (Bache et al., 2014a, Bache et al., 2012a).

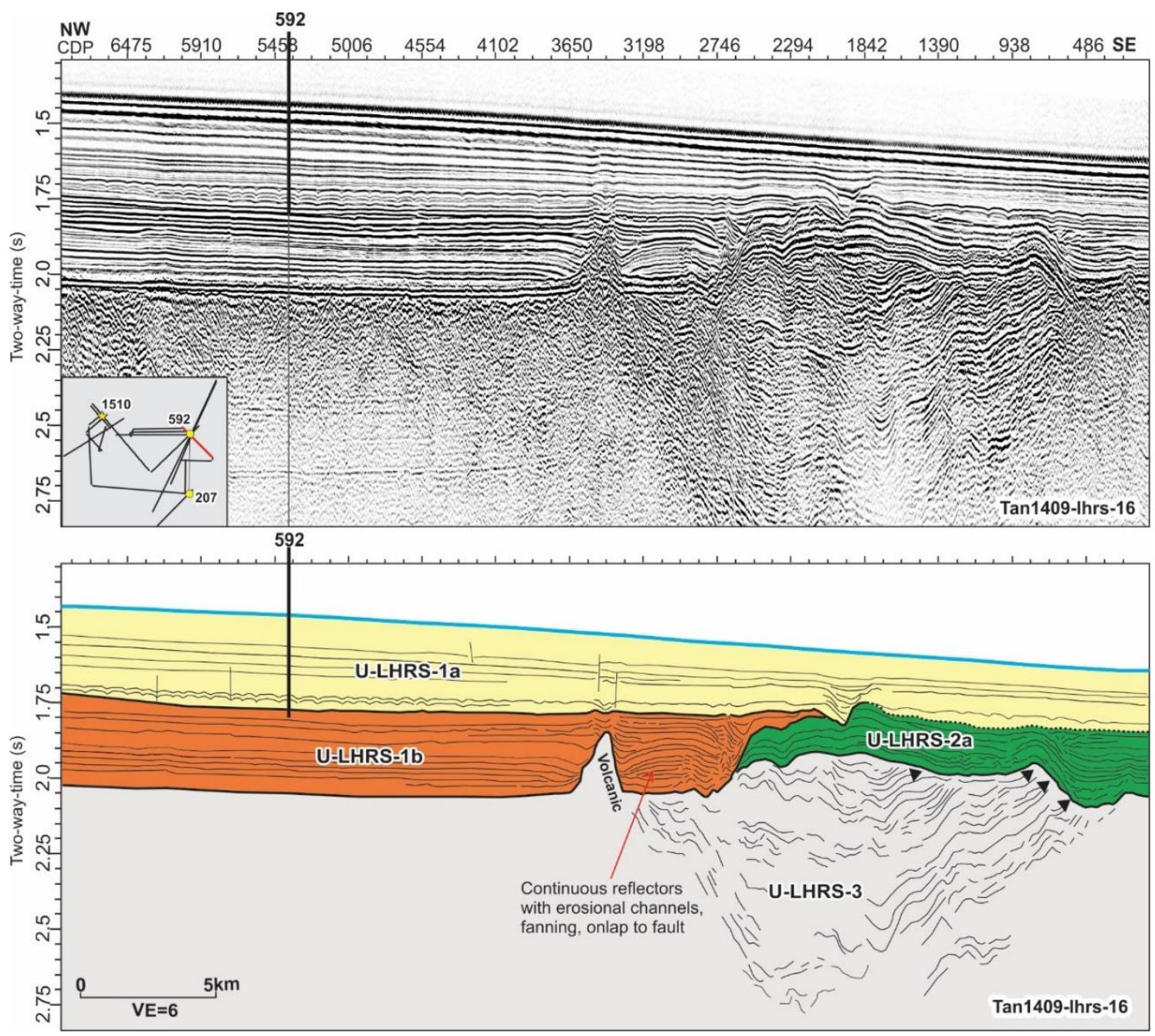

Figure 3.4. TAN1409-LHRS-16 seismic reflection image (above) and sketch interpretation of Seismic Units U-LHRS-1a, U-LHRS-1b, U-LHRS-2a and U-LHRS-3 (below). Folded reflectors truncated of ULHRS-3, folded U-LHRS-2a, and continuous reflectors with channels U-LHRS-U1b. 


\subsubsection{U-LHRS-2b}

U-LHRS-2b has variable amplitude and continuity of reflectors (Fig. 3.3, 3.5, Table 3.1). U-LHRS-2b is characterised by moderate to high-amplitude with moderate to continuous reflectors. U-LHRS-2b has a highly-variable thickness and fanning reflectors are observed close to normal faults, e.g. near Site U207 (Fig. 3.5). The thickness the ULHRS-2b is locally (seismic line 114-06) about 0.1 to $0.6 \mathrm{~s}$ TWT (Fig. $3.5 \& 3.6 \mathrm{~A}$ ). The upper boundary of U-LHRS-2b locally truncates reflectors and is interpreted as an unconformity (Fig. 3.3) (Sutherland et al., 2010), but is a conformity or disconformity over most of the region. U-LHRS-2b is highly localised in small faulted depressions, and therefore it is difficult to define its thickness.

\subsubsection{U-LHRS-2a}

U-LHRS-2a is mapped as moderate to high-amplitude continuous reflectors, which are locally folded and reverse faulted (Fig. 3.3, 3.4, 3.5 \& Table 3.1). U-LHRS-2a is thinner (<0.5 s TWT) near Site U207 than at Site U1510 (Fig. 3.6B). The thickness of U-LHRS-2a is 0.2 to $0.9 \mathrm{~s}$ TWT (Fig. 3.6B). The channel and growth strata of U-LHRS$1 \mathrm{~b}$ lie on top of folded and reverse faulted U-LHRS-2a. U-LHRS-2a near Site U592 is folded with parallel to subparallel reflectors (Fig 3.3, 3.4 \& 3.5). U-LHRS-2a near Site U207 is mapped as low to moderate amplitude continuous reflectors in its upper part, and the lower part has high amplitude continuous reflectors that contain a broken or blocky appearance in some places (Fig $3.4 \& 4.16$ ). 


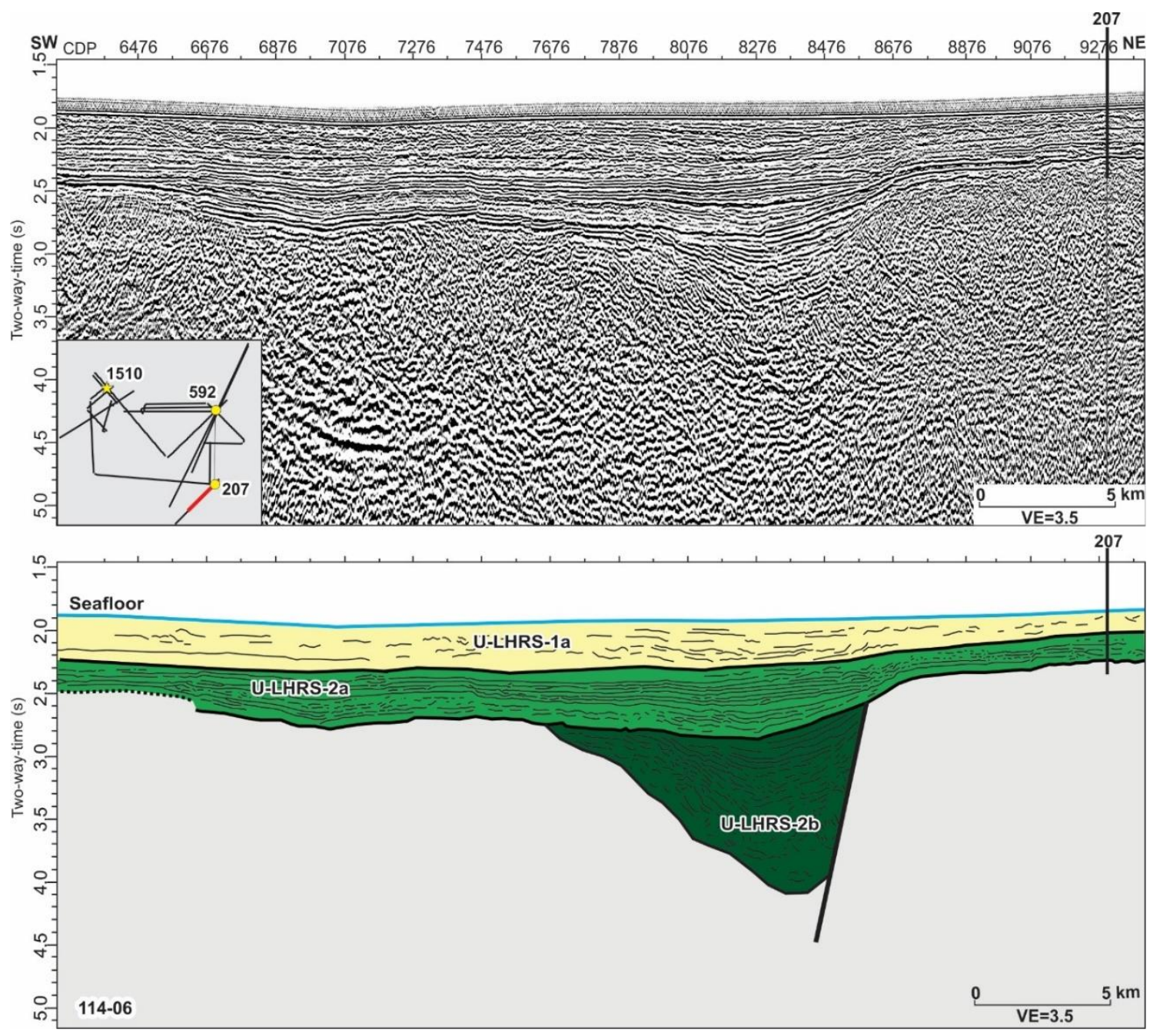

Figure 3.5. 114-06 seismic reflection image (above) and sketch interpretation of Seismic Units U-LHRS1a, U-LHRS-2a and U-LHRS-2b (below). Seismic Units U1a, U2a and U2b near Site U207, where an Eocene-Miocene erosion surface (disconformity) separates U-LHRS-2a and U-LHRS-1a. 

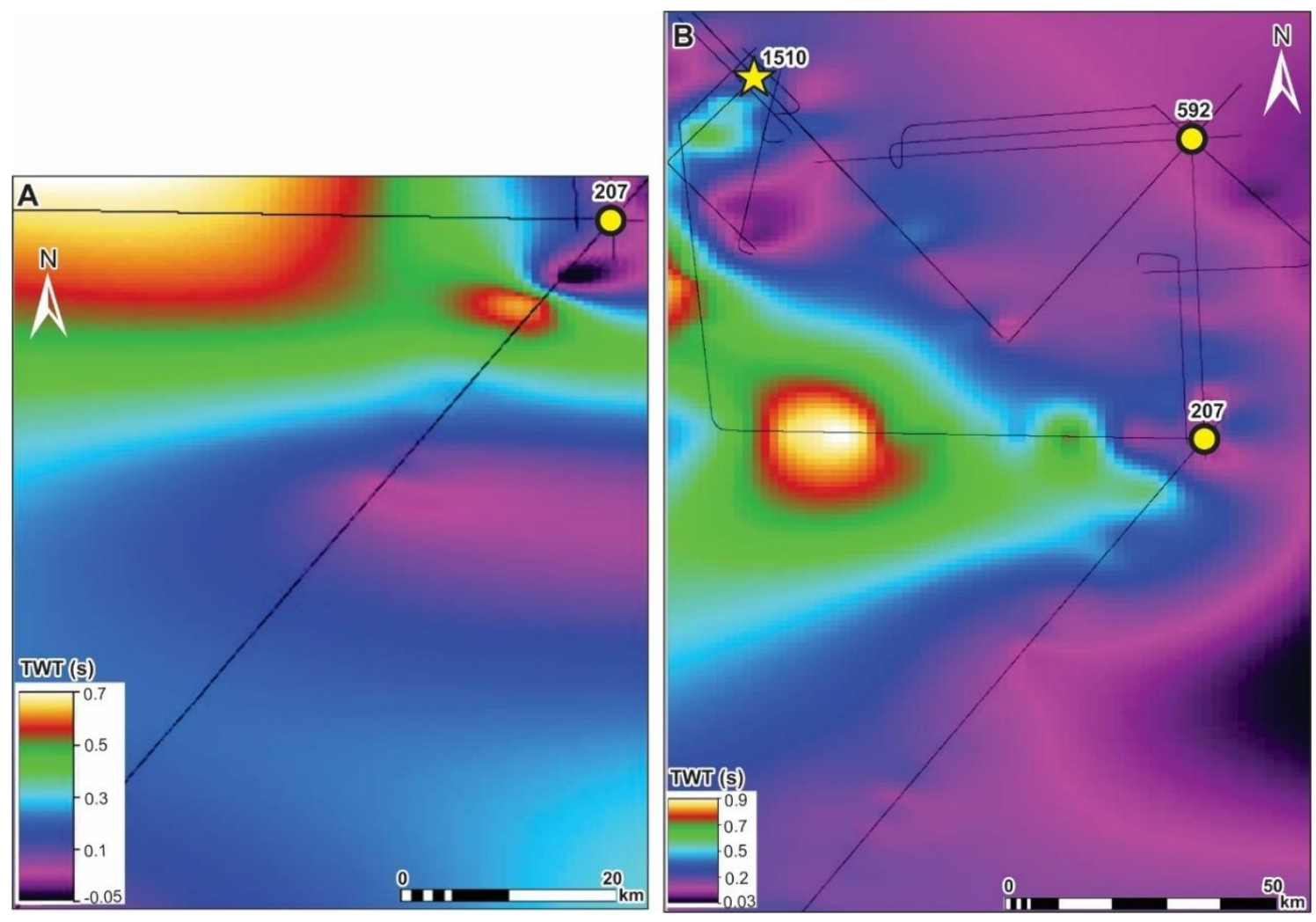

Figure 3.6. Unit thicknesses in second two-way time (TWT): (A) U-LHRS-2b near Site U207, and (B) ULHRS-2a.

\subsubsection{U-LHRS-1b}

U-LHRS-1b is characterised by high-amplitude continuous reflectors, lateral continuity, and with prominent channel forms (Fig. 3.3 3.4. \& Table 3.1). U-LHRS-1b buries a narrow highly reflective mound and a similar feature is found near Site U592 (Fig. 3.4 \& 4.17). Near Site U592, U-LHRS-1b basal high amplitude channel reflectors onlap folded U-LHRS-2a (Fig. 3.4). Near Site U1510, U-LHRS-1b contains a channel that cuts into its top surface and has fanning low to moderate amplitude continuous undulating reflectors (Fig. $4.11 \& 4.12$ ). The thickness of U-LHRS-1b is variable and depends on folds and reverse faults beneath U-LHRS-1b. U-LHRS-1b is missing at Site U207 (Fig. 3.5). The thickness of U-LHRS-1b ranges from $0.04-0.5 \mathrm{~s}$ (Fig. 3.7A \& B). 


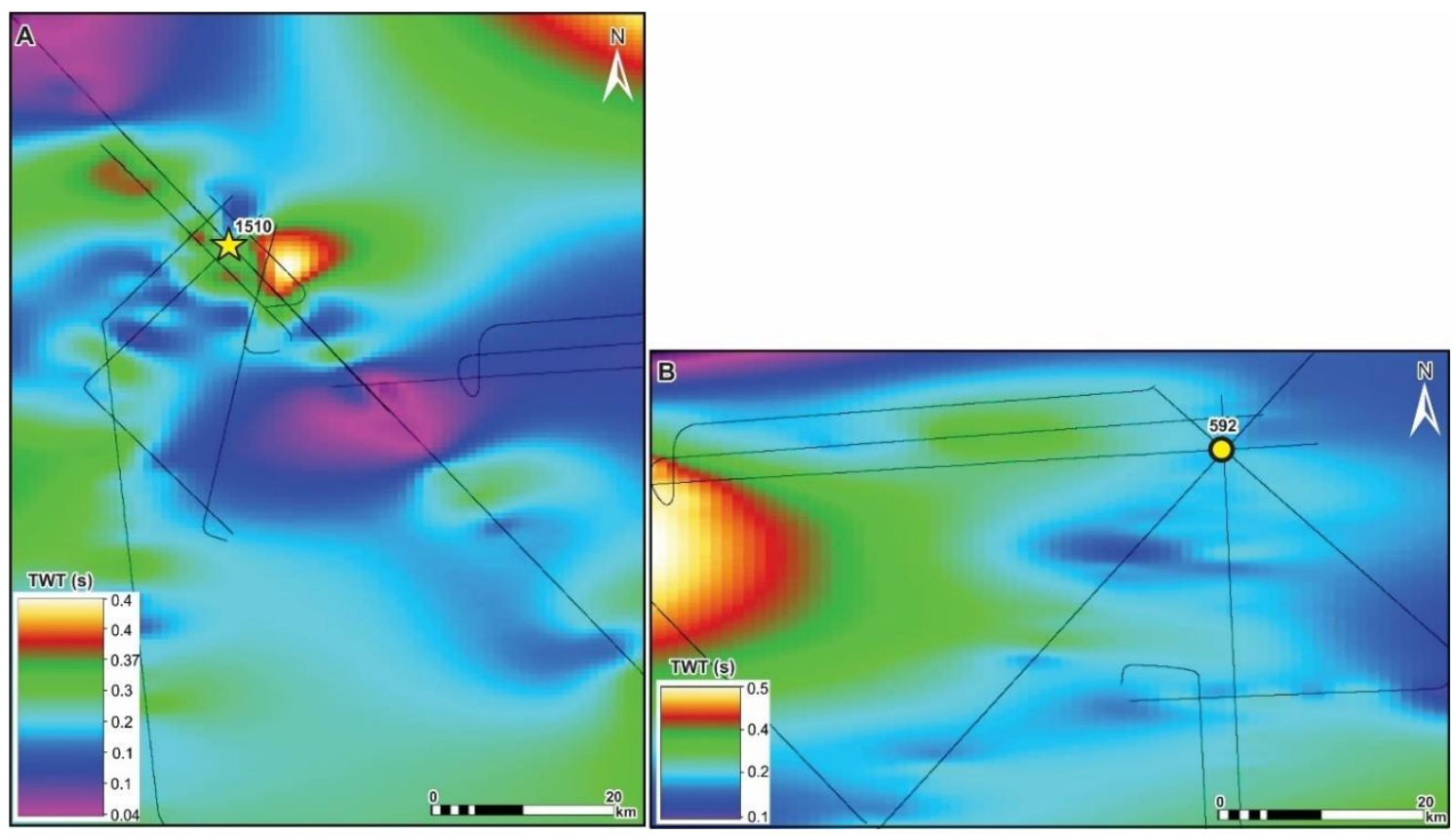

Figure 3.7. Unit thicknesses in second two-way time (TWT): (A) U-LHRS-1b near Site U1510, and (B) U-LHRS-1b near Site U592.

\subsubsection{U-LHRS-1a}

U-LHRS-1a is mapped as variable amplitude continuous reflectors (Fig. 3.3, 3.4, 3.5 \& Table 3.1). Flat-lying continuous reflectors are observed near Site U592. U-LHRS-1a contains some complex bedforms with moderate-amplitude continuous reflectors observed at Site U1510 (Fig. 4.11), and reflectors show local onlapping relationships (Fig. 3.4, $4.11 \& 4.12$ ). U-LHRS-1a has thickness near Site U1510 of 0.3 to $0.6 \mathrm{~s}$ TWT, and near Sites U207 and U592 of about 0.3 s TWT. 


\subsection{Northern Lord Howe Rise (LHRN)}

Numerous studies are published (Hashimoto et al., 2010, Willcox et al., 2001, Stagg et al., 2002, Willcox and Sayers, 2002) on stratigraphy and structural analysis of the region. Previous work defined Mesozoic (inferred) stratigraphy of the region as Syn-rift (1 and 2) and Sag 1 (Table 3.2) (Higgins et al., 2015, Norvick et al., 2008a, Willcox and Sayers, 2001, Willcox et al., 2001), and Late Cretaceous-Paleocene post-rift is Sag 1 and Cenozoic is Sag 2 (Table 3.2). I based my mapping on previous work of Colwell et al. (2010), Higgins et al. (2015), and Sutherland et al. (2010); with nomenclature after Bache et al. (2014) (Table $3.2 \&$ 3.8). I mapped pre-rift 'basement' as Seismic Unit U-LHRN-3; Syn-rift and Sag 1 as U-LHRN-2b1 (Syn-rift 2) and U-LHRN-2b2 (Syn-rift 1) (Fig. 3.8 \& 3.9). Post-rift and Sag 1 are U-LHRN-2a and Sag 2 is Seismic Unit U-LHRN-1 (Table $3.2 \&$ Fig. 3.8) (Bache et al., 2014a, Colwell et al., 2010a, Higgins et al., 2015, Sutherland et al., 2010).

Table 3.2. LHRN Seismic units characteristics.

\begin{tabular}{|c|c|c|c|}
\hline $\begin{array}{l}\text { Seismic } \\
\text { Units }\end{array}$ & Seismic pattern \& key features & Previously named & References \\
\hline U-LHRNN-1a & $\begin{array}{l}\text { - Unconformity prominent in } \\
\text { someplace with flat-lying to } \\
\text { internal complex geometry } \\
\text { with a little volcanic on the top } \\
\text { - Continuous unit with } \\
\text { polygonal faults } \\
\text { - Onlaps } \\
\text { - } \quad \text { Drape material } \\
\text { - Filling V-shape channel }\end{array}$ & $\begin{array}{l}\text { Sag } 2 \text { (Sutherland et al., } \\
\text { 2010); Post-rift Drape } \\
\text { sediment (Colwell et al., } \\
\text { 2010a, Higgins et al., } \\
\text { 2015) }\end{array}$ & \multirow[t]{5}{*}{$\begin{array}{l}\text { (Colwell et } \\
\text { al., 2010b, } \\
\text { Higgins et } \\
\text { al., 2015, } \\
\text { Hashimoto } \\
\text { et al., 2009, } \\
\text { Sutherland } \\
\text { et al., 2010) }\end{array}$} \\
\hline U-LHRN-1b & $\begin{array}{ll}\text { - } & \text { Discontinuous reflectors } \\
\text { - } & \text { Thin section } \\
\text { - } & \text { hiatus }\end{array}$ & $\begin{array}{l}\text { Sag } 2 \text { (Sutherland et al., } \\
\text { 2010); }\end{array}$ & \\
\hline U-LHRN-2a & $\begin{array}{ll}- & \text { Erosional truncations } \\
\text { - } & \text { unconformity } \\
\text { - } & \text { Parallel, clinoformal } \\
\text { - } & \text { Variable frequency and } \\
& \text { amplitude reflectors }\end{array}$ & $\begin{array}{l}\text { Sag } 1 \text { (Sutherland et al., } \\
\text { 2010); Upper and Lower } \\
\text { Sag sediment, Post-rift } \\
\text { Sag (Colwell et al., } \\
\text { 2010a, Higgins et al., } \\
\text { 2015) }\end{array}$ & \\
\hline U-LHRN-2b & $\begin{array}{ll}\text { - } & \text { Parallel, moderate to high } \\
& \text { amplitude reflectors } \\
\text { - } & \text { Normal faulting } \\
\text { - } & \text { Multiples phases of syn-rift } \\
& \text { Unconformity unit }\end{array}$ & $\begin{array}{l}\text { Sag } 1 \text { (Sutherland et al., } \\
\text { 2010); Syn-rift } 2 \& \text { Syn- } \\
\text { rift-1 (Colwell et al., } \\
\text { 2010a, Higgins et al., } \\
\text { 2015) }\end{array}$ & \\
\hline U-LHRN-3 & $\begin{array}{l}\text { Variable chaotic to locally } \\
\text { continuous, stratified within tilted } \\
\text { blocks }\end{array}$ & $\begin{array}{l}\text { Pre-rift \& basement } \\
\text { (Colwell et al., 2010a, } \\
\text { Higgins et al., 2015) }\end{array}$ & \\
\hline
\end{tabular}




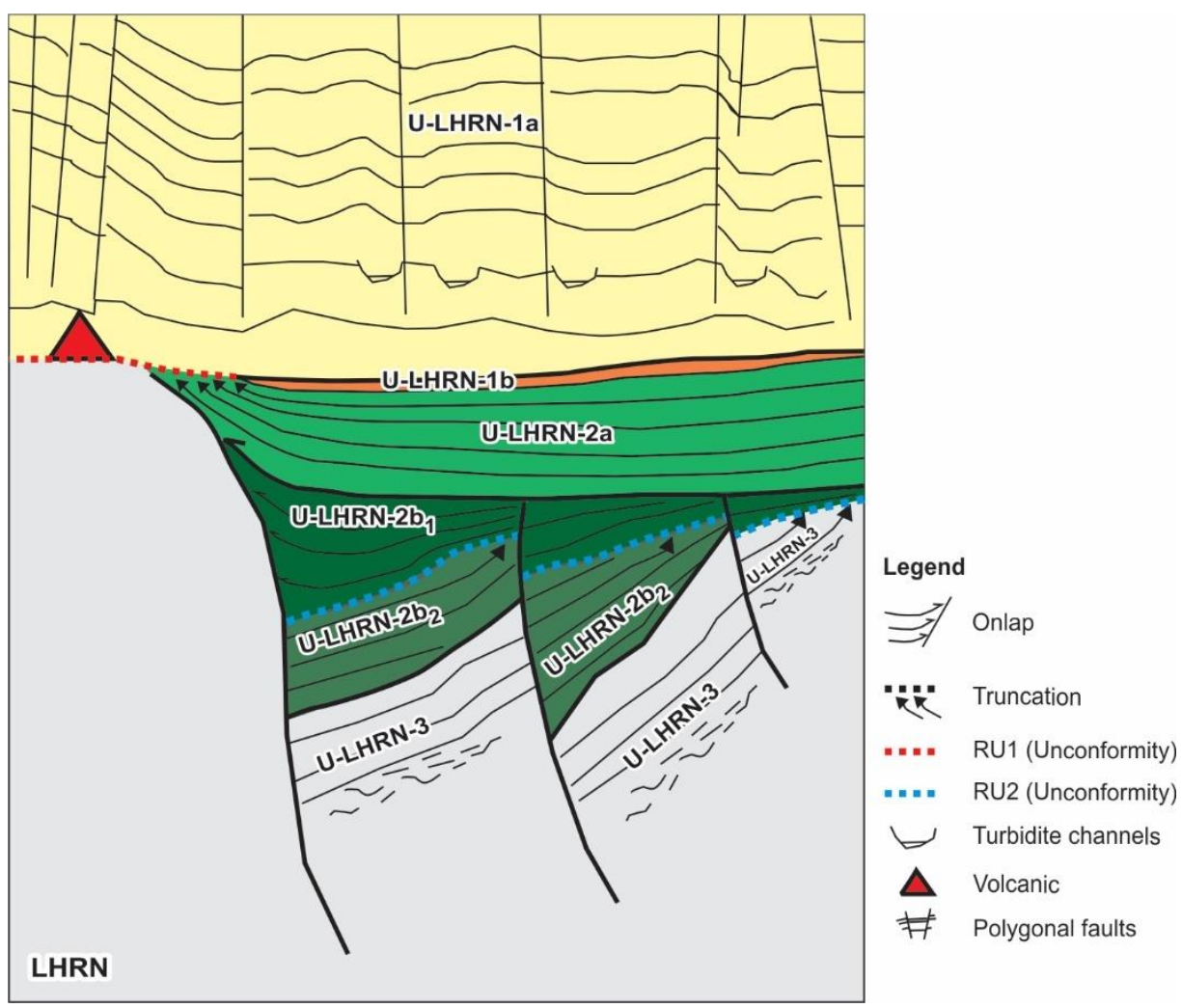

Figure 3.8. Seismic stratigraphy cartoon for northern Lord Howe Rise (LHRN).

\subsubsection{U-LHRN-3}

U-LHRN-3 is characterised by variable amplitude chaotic to locally continuous reflectors (Fig. 3.8, 3.9, 3.10 \& Table 3.2). U-LHRN-3 contains layered facies featuring subparallel to parallel reflectors that are truncated by faults, and at unconformity RU2 at its top (Fig. 3.10). The thickness is unknown because the base of the unit is not imaged.

\subsection{2 $\underline{\text { U-LHRN-2b }}$}

U-LHRN-2b is found in NNW-trending grabens that are offset by NE-trending accommodation zones (Willcox et al., 2001). U-LHRN-2b (Fig. 3.8, 3.9 \& Table 3.2) can be divided into sub-units U-LHRN-2 $b_{1}$ and U-LHRN-2 $b_{2}$ (Fig. 3.9). U-LHRN-2 $b_{1}$ has parallel, divergent reflectors with high amplitude, and moderate continuity that are inferred to be growth strata adjacent to bounding faults (Fig. 3.8 \& 3.9) (Colwell et al., 2010b, Higgins et al., 2015). There are some blocky high-amplitude and discontinuous reflectors that may indicate the presence of coal and lacustrine deposition accompanying 
faulting during initial rifting (Hashimoto et al., 2012). U-LHRN-2 $\mathrm{b}_{1}$ has thickness up to $\sim 2.6 \mathrm{~km}$ ( $\sim 0.9$ to $1.5 \mathrm{~s}$ TWT) (Higgins et al., 2015). U-LHRN-2 $\mathrm{b}_{2}$ has a typical thickness of about $1.1 \mathrm{~km}$ where it can be identified (Higgins et al., 2015) and contains parallel reflectors with moderate to high-amplitude. U-LHRN-2 $b_{2}$ has maximum mapped thickness of $\sim 2.8 \mathrm{~km} 1.5 \mathrm{~s}$ TWT in northern Western Flank (Higgins et al., 2015).

\subsubsection{U-LHRN-2a}

U-LHRN-2a is characterised by parallel, high-amplitude reflectors with high continuity (Table 3.2, Fig. $3.9 \&$ 3.10) (Colwell et al., 2010b, Higgins et al., 2015). Faults that bound or offset the U-LHRN-2b sequence show little or no offset of U-LHRN-2a (Fig. 3.8 \& 3.9) (Higgins et al., 2015). U-LHRN-2a is locally truncated overlying by ULHRN-U1a and underlying by U-LHRN-3 (Fig. 3.8, $3.9 \&$ 3.10). The thickness of ULHRN-2a is mostly $\sim 0.5 \mathrm{~s}$ TWT. 

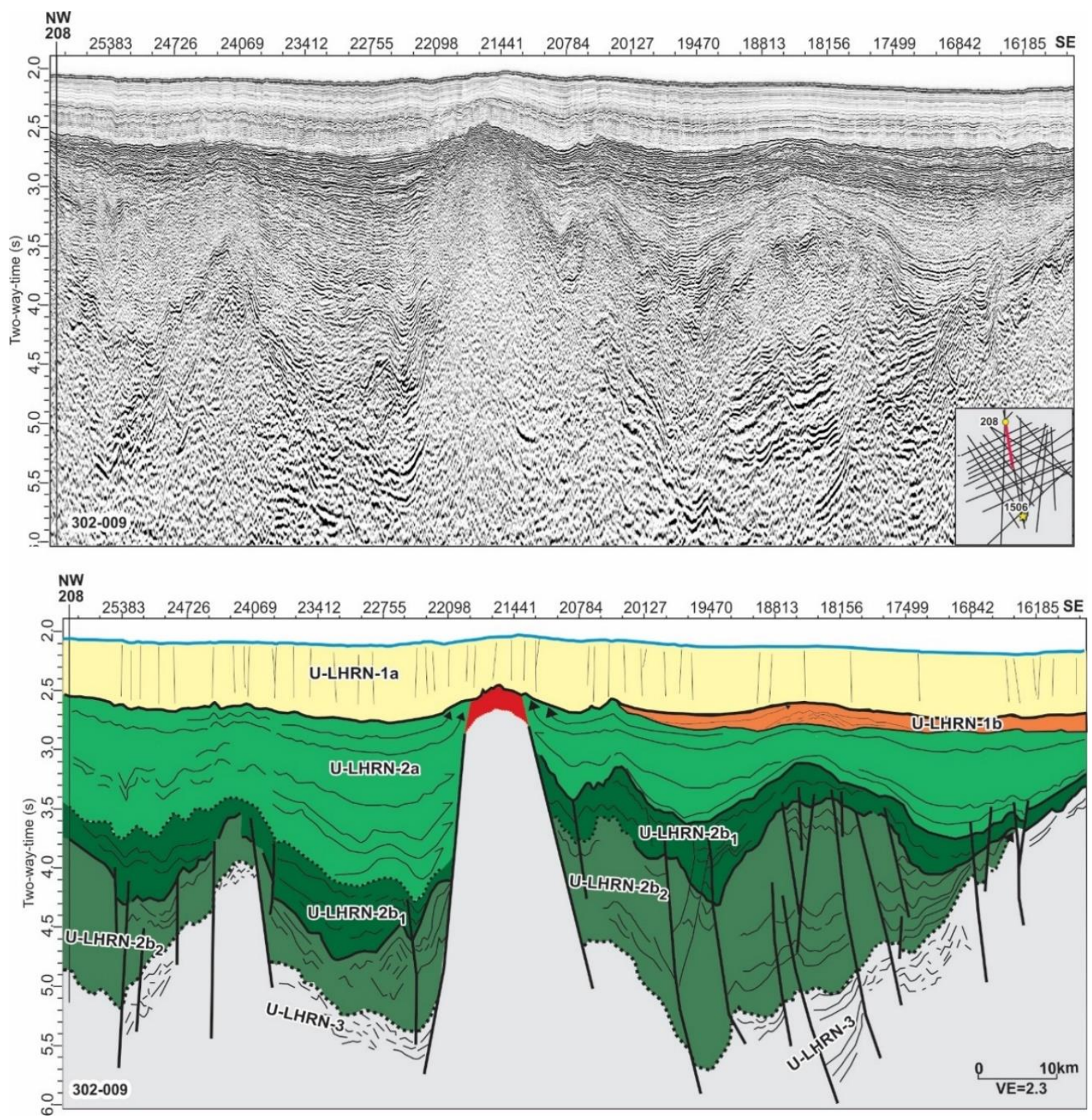

Figure 3.9. 302-009 seismic reflection image (above) and sketch interpretation of Seismic Units U-LHRN1a, U-LHRN-1b, U-LHRN-2a, U-LHRN-2 b $_{1}$ U-LHRN-2 $\mathrm{b}_{2}$ and U-LHRS-3 (below).

\subsubsection{U-LHRN-1b}

U-LHRN-1b is characterised by a thin parallel layer with high to moderate amplitude reflectors (Fig. 3.8, 3.9, 3.10 \& Table 3.2). U-LHRN-1b is mostly not present and instead represented by an erosional hiatus. Volcanic edifices are associated with the unconformity that lies in place of U-LHRN-1b (Higgins et al., 2015, Rollet et al., 2012). 

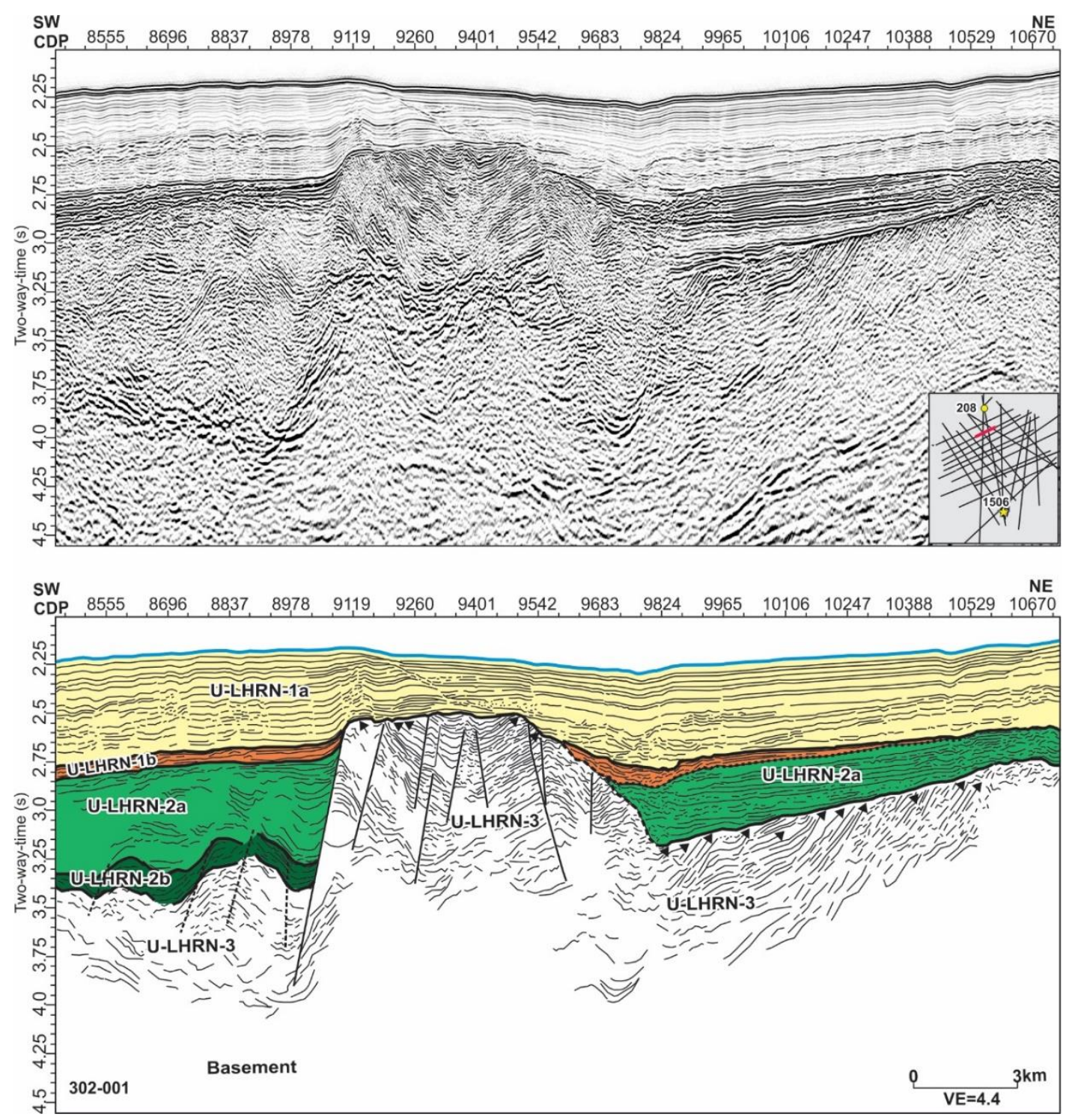

Figure 3.10. 302-001 seismic reflection image (above) and sketch interpretation of Seismic Units ULHRN-1a, U-LHRN-1b, U-LHRN-2a, U-LHRN2b and U-LHRN-3. U-LHRN-3 is onlapped by U-LHRN2a. Black arrows $=$ truncation.

\subsubsection{U-LHRN-1a}

U-LHRN-1a is mapped as parallel low-amplitude reflectors (Fig. 3.8, 3.9, 3.10 \& Table 3.2). A high-amplitude continuous reflector observed at the base of U-LHRN-1a is shown at Site U208 to be an Eocene-Oligocene unconformity. This distinctive reverse polarity reflection separates chalk of U-LHRN-1a from siliceous ooze of U-LHRN-2a (Fig. $3.9 \&$ 310). U-LHRN-1a is up to $800 \mathrm{~m}$ (1.5 s TWT) thick and dominated by calcareous foraminiferal and nannofossil chalk and ooze (Burns and Andrews, 1973) (Higgins et al., 2015, Colwell et al., 2010b, Burns and Andrews, 1973) to the south of Site U208. U-LHRN-1a has complex bedding over a volcanic complexes (Rollet et al., 2012). 


\subsection{Fairway Basin (FWAY)}

The stratigraphy of Fairway Basin (FWAY) was described in detail by Rouillard et al. (2014), Rouillard et al. (2015), Collot et al. (2009), and Bache et al. (2014a); and hence this section only presents seismic figures from the recent TECTA survey (Fig. 1.2, Fig. 3.13 \& Fig. 3.14). I used new seismic data, the TECTA survey (Collot et al., 2016), to correlate and connect FWAY, LHRN and Norfolk Ridge with NCTN (Fig. 1.1 \& 3.24). I mapped FWAY into three units: U-FWAY-1 (U1a \& U1b), U-FWAY-2 (U2a \& U2b) and U-FWAY-3. The seismic pattern and key features are presented in Table 3.3 and Figure 3.11 and recent TECTA seismic data as presented in Figure $3.13 \& 3.14$.

Table 3.3. FWAY Seismic units characteristics.

\begin{tabular}{|c|c|c|c|}
\hline $\begin{array}{l}\text { Seismic } \\
\text { Units }\end{array}$ & $\begin{array}{c}\text { Seismic pattern \& key } \\
\text { features }\end{array}$ & Previously named & References \\
\hline U-FWAY-1a & $\begin{array}{ll}\text { - } & \text { Conformable } \\
\text { - } & \text { Erosive complex in the } \\
\text { central basin } \\
\text { - } \\
\text { Continuous unit with } \\
\text { polygonal faults } \\
\text { - Onlaps }\end{array}$ & $\begin{array}{l}\text { Zealandia U1a (Bache } \\
\text { et al., 2014a); Fw1a } \\
\text { (Rouillard et al., 2015) }\end{array}$ & \multirow[t]{5}{*}{$\begin{array}{l}\text { (Auzende et al., } \\
2000 \mathrm{~b} \text {, Auzende et } \\
\text { al., 2000a, Collot et } \\
\text { al., } 2009 \text {, } \\
\text { Hashimoto et al., } \\
2010 \text {, Rouillard et } \\
\text { al., 2015) }\end{array}$} \\
\hline U-FWAY-1b & $\begin{array}{ll}\text { - } & \text { Downlap } \\
\text { - } & \text { Onlap } \\
\text { - } & \text { Prograding series }\end{array}$ & $\begin{array}{l}\text { Zealandia U1b (Bache } \\
\text { et al., 2014a); Fw1b } \\
\text { (Rouillard et al., 2015) }\end{array}$ & \\
\hline U-FWAY-2a & $\begin{array}{l}\text { - Slightly folded } \\
\text { - } \quad \text { Diapirs } \\
\text { - } \text { Shelf type of feature, } \\
\text { prograding wedges along } \\
\text { the LHR in the NW } \\
\text { - } \quad \text { Fanning reflectors }\end{array}$ & $\begin{array}{l}\text { Zealandia U2a (Bache } \\
\text { et al., 2014a); Fw2a } \\
\text { (Rouillard et al., 2015) }\end{array}$ & \\
\hline U-FWAY-2b & $\begin{array}{ll}\text { - } & \text { Normal faulting } \\
\text { - Half-graben in the south }\end{array}$ & $\begin{array}{l}\text { Zealandia U2b (Bache } \\
\text { et al., 2014a); Fw2b } \\
\text { (Rouillard et al., 2015) }\end{array}$ & \\
\hline U-FWAY-3 & $\begin{array}{ll}\text { - } & \text { continuous and stratified } \\
& \text { reflections } \\
\text { - } & \text { chaotic packages } \\
\text { - } & \text { horst, tilting blocks, normal } \\
& \text { faults } \\
\text { - } & \text { Toplaps }\end{array}$ & $\begin{array}{l}\text { Zealandia U3 (Bache } \\
\text { et al., 2014a); Fw3 } \\
\text { (Rouillard et al., 2015) }\end{array}$ & \\
\hline
\end{tabular}




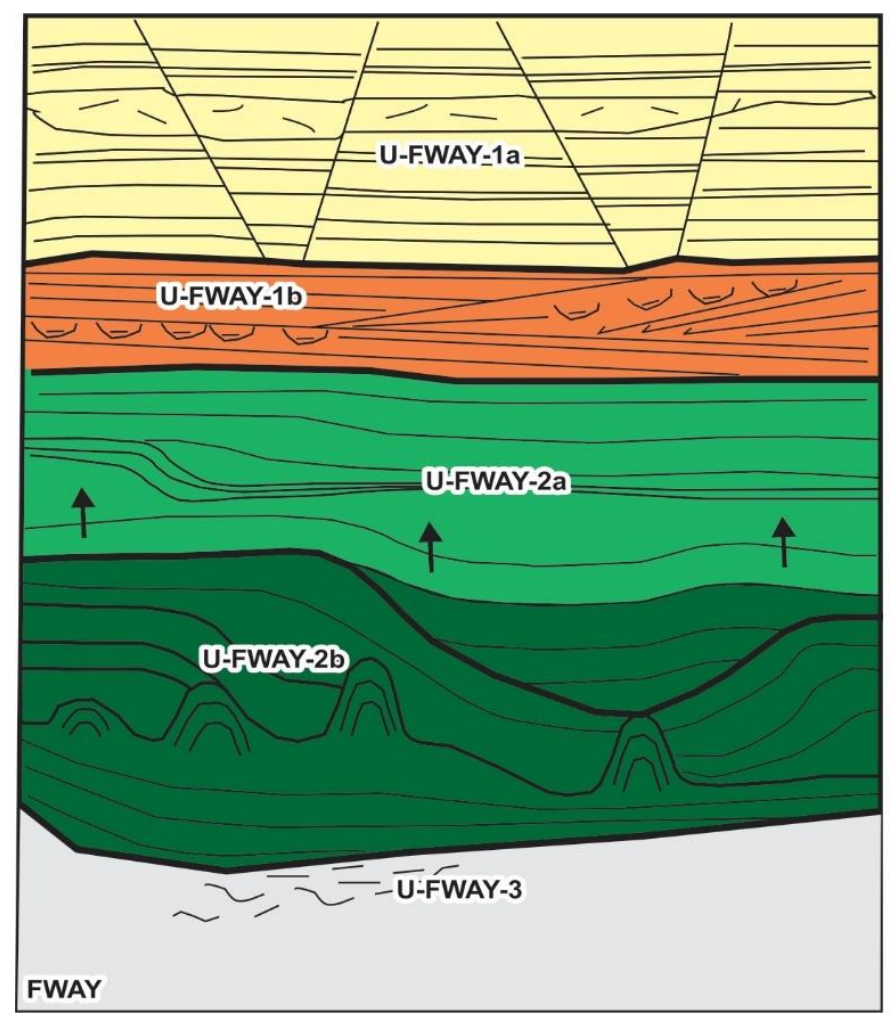

Legend

$\Uparrow$ Diapir

$\sim$ Fold

$\checkmark$ Turbidite channels

D) Downlap

$\exists$ Onlap

NNT Mas-transport deposit

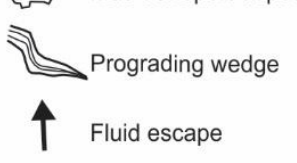

Figure 3.11. Seismic stratigraphy cartoon is modified from Rouillard et al. (2015) illustrating seismic units of Fairway Basin (FWAY).

\subsubsection{U-FWAY-3}

U-FWAY-3 corresponds to acoustic basement and is characterised by chaotic high amplitude to locally continuous and stratified reflections within horsts and titled blocks (Fig. 3.11 \& Table 3.3) (Bache et al., 2014b, Exon et al., 2007, Rouillard et al., 2015). The top of U-FWAY-3 is a high-amplitude reflector with variable continuity. U-FWAY3 is folded and faulted (Collot et al., 2009, Exon et al., 2007, Lafoy et al., 2005, Rouillard et al., 2015), and the thickness is unknown because it is only locally reflective and no clear base to the unit is visible. 


\section{4 .2 U-FWAY-2b}

U-FWAY-2b is characterised by moderate to high-amplitude continuous reflectors (Table 3.3 \& Fig. 3.12). U-FWAY-2b has clinoform overlapping mounded features in the north and fanning geometries filling half-grabens in the south of the Basin (Auzende et al., 2000b, Rouillard et al., 2015, Exon et al., 2007). U-FWAY-2b has variable-amplitude clinoform reflectors that onlap onto horsts of Lord Howe Rise and Fairway Ridge (Exon et al., 2007, Bache et al., 2014a, Rouillard et al., 2015, Rouillard et al., 2017). The upper boundary of the U-FWAY-2b is a continuous high-amplitude reflector (Collot et al., 2009, Rouillard et al., 2015). U-FWAY-2b has restricted distribution but locally has a thickness of up to1.1 s TWT (Rouillard et al., 2015).
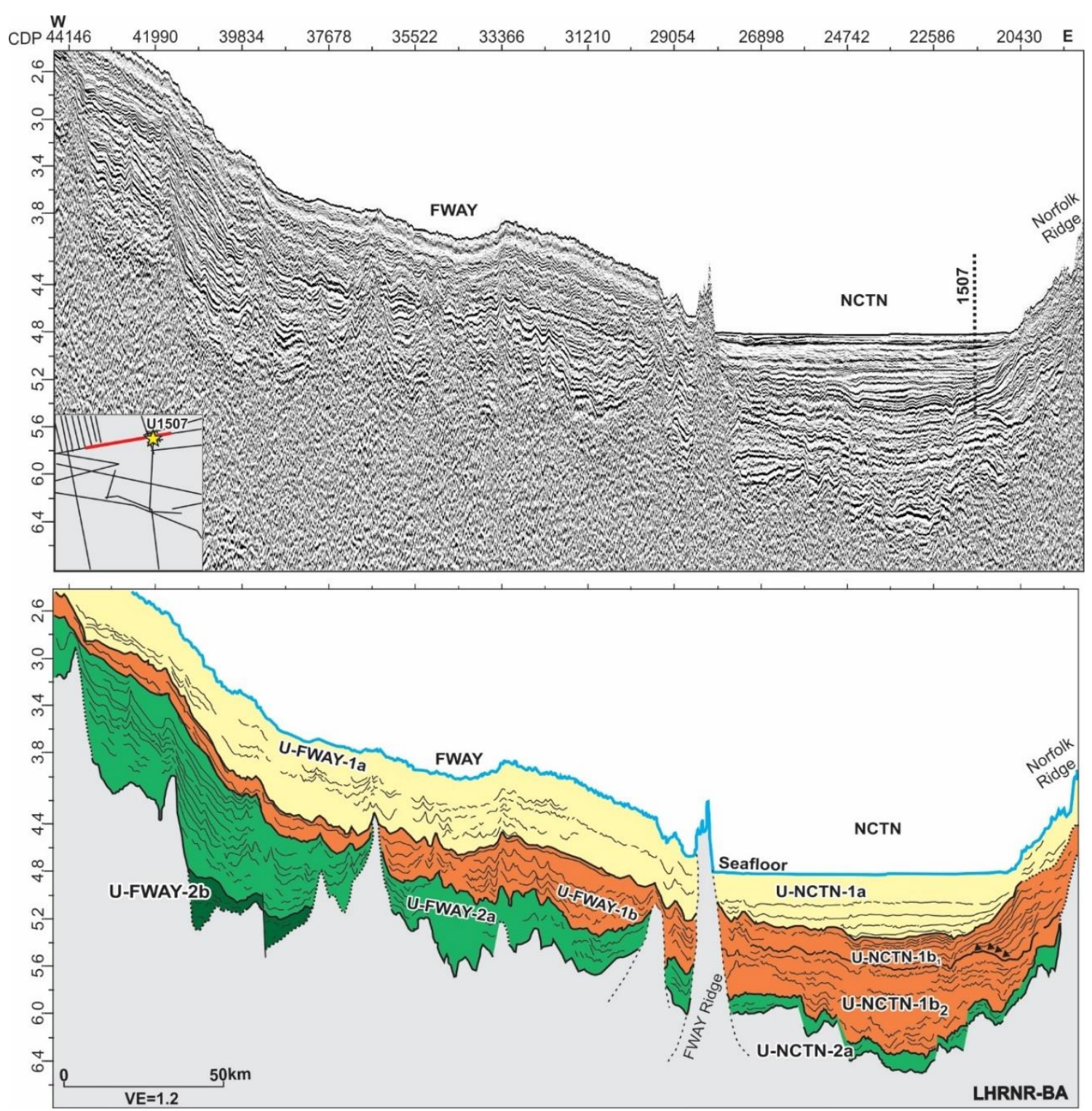

Figure 3.12. LHRNR-BA seismic reflection image (above) and sketch interpretation of Seismic Units $2 b$, 2a, $1 \mathrm{~b}$ and $1 \mathrm{a}$ (U2b, U2a, U1b and U1a) in FWAY and NCTN (below). 

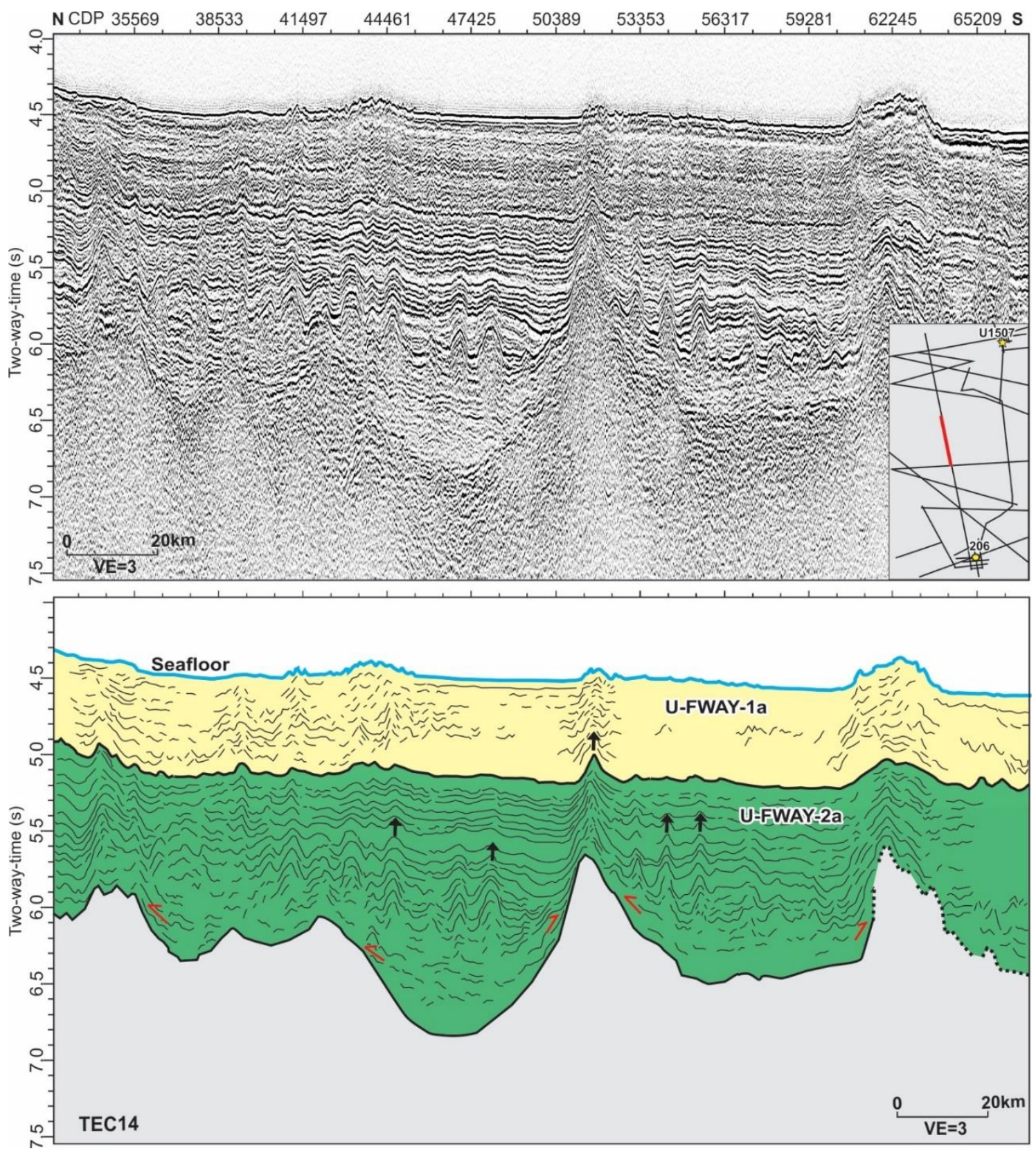

Figure 3.13. TEC14 seismic reflection image (above) and sketch interpretation of Seismic Units UFWAY-1a and U-FWAY-2a (below). Seismic Unit U-FWAY-2a with mounded features interpretation as diapirs (Auzende et al., 2000b). Black arrows=fluid scapes and red arrows=onlaps. 


\subsubsection{U-FWAY-2a}

U-FWAY-2a has medium to high amplitude reflectors with slight folding, and onlap into U-FWAY-2b (Table 3.3, Fig. 3.11, 3.12 \& 3.13) (Collot et al., 2009, Lafoy et al., 2005, Rouillard et al., 2015). U-FWAY-2a is affected by diapirism and fluid expulsion above diapirs (Fig. $3.11 \& 3.13$ ) (Auzende et al., 2000b). There are thin sigmoid seismic facies on the eastern flank of Lord Howe Rise (Rouillard et al., 2017). The top of UFWAY-2a is associated with erosion and truncation adjacent to Lord Howe Rise and Fairway Ridge. U-FWAY-2a is deformed near Site U206 (Fig. 3.13). U-FWAY-2a has variable thickness from 0.6 to $1.1 \mathrm{~s}$ TWT (Fig. 3.15B) (Rouillard et al., 2015).

\subsubsection{U-FWAY-1b}

U-FWAY-1b as a stacked prograding series of high to medium amplitude continuous reflectors (Rouillard et al., 2015). Prograding series have variable directions (west to east or east to west), as indicated by downlaps and onlaps onto U-FWAY-2a (Fig. 3.11, 3.12, $3.12 \&$ Table 3.14). U-FWAY-1b has high amplitude reflectors isolated within V-shape depressions. These facies are interpreted as channels, with high amplitude reflectors interpreted as coarse-grained channel infill (Damuth et al., 1988). South of Fairway Basin, near Site U206, the borehole U206 crosses small faults related to local deformation where the unit is unsampled (Fig. 3.15). Turbidite systems with channel-levee features indicate there was sediment supply from surrounding ridges. The thickness of U-FWAY-1b is < 0.7 s TWT (Fig. 3.15C) (Rouillard et al., 2015).

The upper part of U-FWAY-1b contains a bottom-simulating reflector (BSR) that was identified by Auzende et al., (2000) and Nouzé et al., (2009). This BSR is observed throughout Fairway Basin, and Nouzé et al. (2009) conclude it is related to silica diagenesis. 

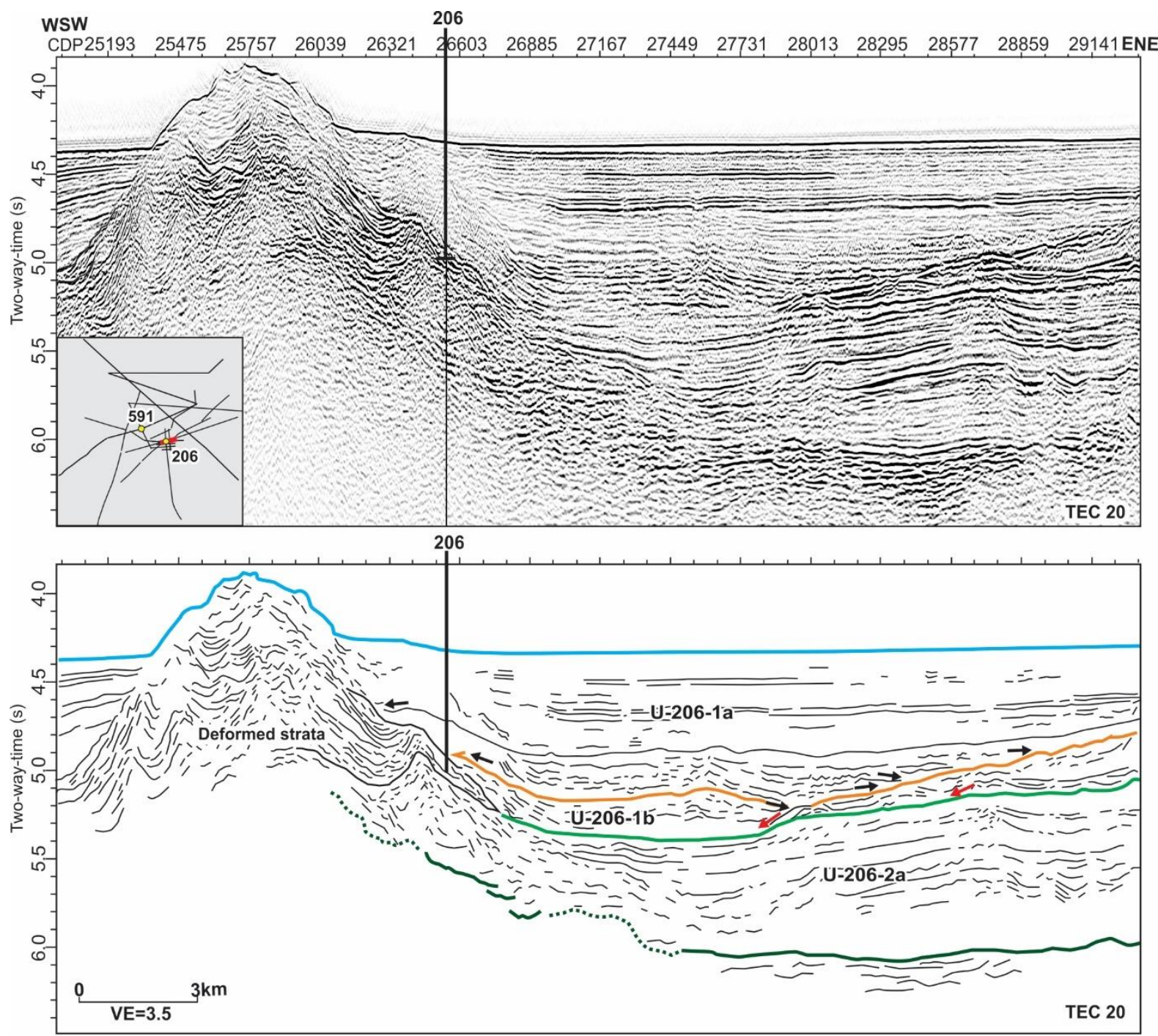

Figure 3.14. Tec 20 near Site U206, seismic reflection image (above) and sketch interpretation of Seismic Units U-206-1a, U-206-1b and U-206-2a (below). Black arrows = onlaps and red arrows = downlaps relationship.

\subsubsection{U-FWAY-1a}

U-FWAY-1a is the shallowest seismic unit and mapped as variable amplitude continuous reflectors with basal onlaps. U-FWAY-1a has low amplitude reflectors with low continuity, suggesting erosive complexes in the central basin (Table 3.3, Fig. 3.11, 3.12 \& 3.13) (Ravenne et al., 1977, Rouillard et al., 2015, Rouillard et al., 2017). UFWAY-1a contains polygonal faulting. U-FWAY-1a is interpreted as aggrading basinal deposits or pelagic draping interrupted by episodic turbidites and mass transport deposits (Rouillard et al., 2015, Rouillard et al., 2017). The thickness of U-FWAY-1a is about 0.8 s TWT (Rouillard et al., 2015). 


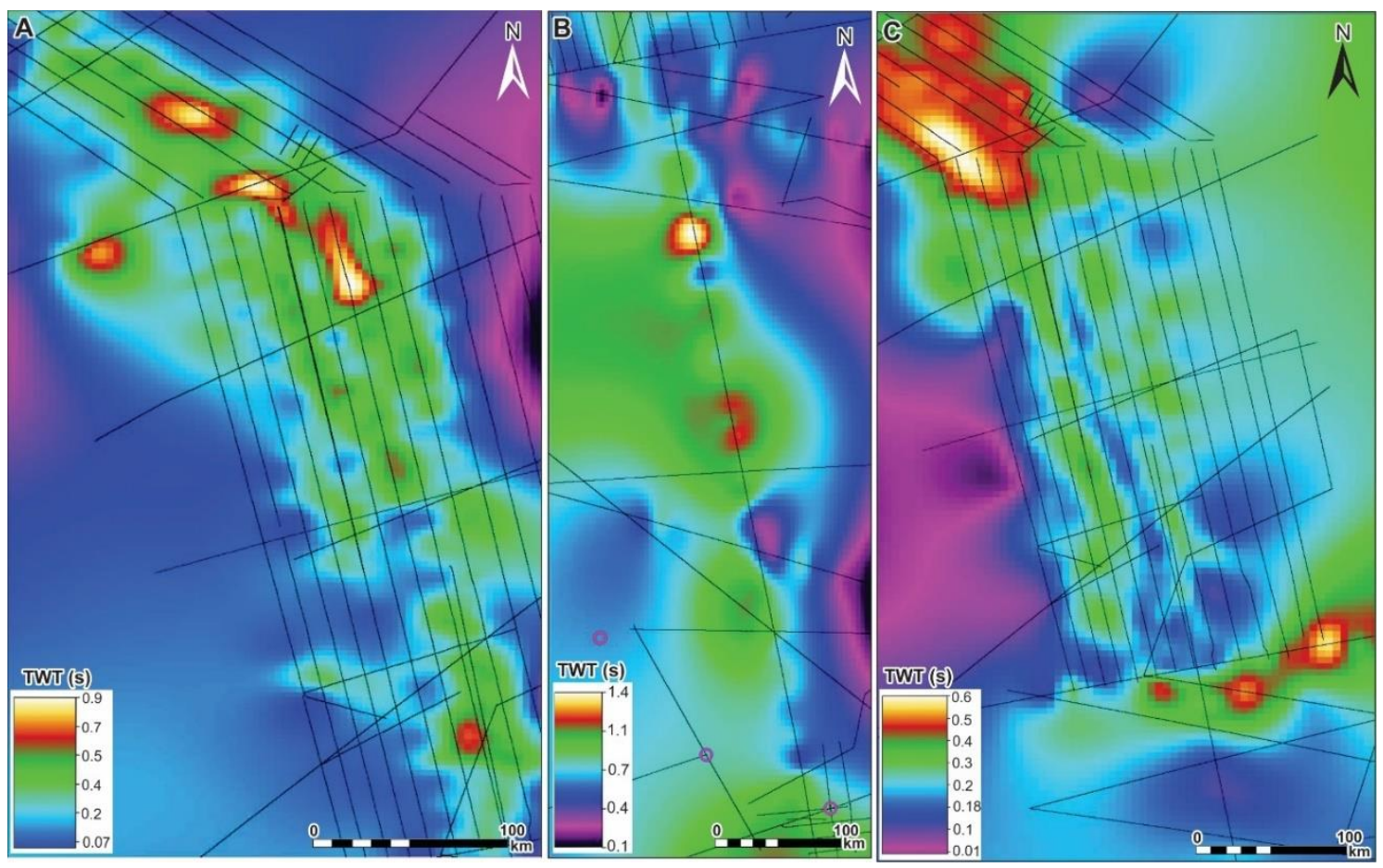

Figure 3.15. Unit thickness in second two-way time (TWT) in FWAY basin, (A) U-FWAY-U2b (B) UFWAY-U2a and, (C) U-FWAY-U1b. 


\subsection{Southern New Caledonia Trough (NCTS)}

Previous work has been done on the seismic stratigraphy of southern New Caledonia Trough (NCTS) (Bache et al., 2014a, Collot et al., 2009, Etienne et al., 2018, Rouillard et al., 2015). I mapped seismic units of NCTS based on broad correlation to horizons of Bache et al. (2014), Collot et al. (2009) and Etienne et al. (2018), and adapted their nomenclature (Table 3.4 \& Fig. 3.16). I mapped three seismic units: Seismic Unit UNCTS-1 (U1a \& U1b), U-NCTS-2 (U2a \& U2b) and U-NCTS-3 (Table 3.4 \& Fig. 3.16). The cartoon in Figure 3.16 is based on sequence-stratigraphic relevance to basin-filling phases and is adapted from previous published work (Bache et al., 2014a, Collot et al., 2009, Etienne et al., 2018, Rouillard et al., 2015).

Table 3.4. NCTS Seismic units characteristics.

\begin{tabular}{|c|c|c|c|}
\hline $\begin{array}{c}\text { Seismic } \\
\text { Units }\end{array}$ & Seismic pattern \& key features & Previously named & References \\
\hline U-NCTS-1a & $\begin{array}{ll}\text { - } & \text { Horizontal-parallel continuous } \\
& \text { reflectors } \\
\text { - } & \text { Onlaps }\end{array}$ & $\begin{array}{l}\text { Zealandia U1a } \\
\text { (Bache et al., } \\
\text { 2014a) }\end{array}$ & \multirow{5}{*}{$\begin{array}{c}\text { (Sutherland } \\
\text { et al., 2010, } \\
\text { King and } \\
\text { Thrasher, } \\
\text { 1996, Baur } \\
\text { et al., 2014, } \\
\text { Bache et } \\
\text { al., 2014a, } \\
\text { Collot et al., } \\
2009 \text {, } \\
\text { Etienne et } \\
\text { al., 2018) }\end{array}$} \\
\hline U-NCTS-1b & $\begin{array}{l}\text { - Syn-tectonic deformation with folding } \\
\text { on the ridge } \\
\text { - Downlaps and wedge geometry } \\
\text { - Onlap termination } \\
\text { - Locally shows slumping }\end{array}$ & $\begin{array}{l}\text { Zealandia U1b } \\
\text { (Bache et al., } \\
\text { 2014a) }\end{array}$ & \\
\hline U-NCTS-2a & $\begin{array}{ll} & \text { Continuous reflectors } \\
\text { - } & \text { Weakly deformed } \\
\text { - Slightly tilted and folded } \\
\text { - }\end{array}$ & $\begin{array}{l}\text { Zealandia U2a } \\
\text { (Bache et al., } \\
\text { 2014a) }\end{array}$ & \\
\hline U-NCTS-2b & $\begin{array}{l}\text { - a basal sequence of variable } \\
\text { thickness } \\
\text { - asymmetric half graben geometries } \\
\text { to be normal faulted in many places } \\
\text { - Locally reverse faulting, } \\
\text { deformation? }\end{array}$ & $\begin{array}{l}\text { Zealandia U2b } \\
\text { (Bache et al., } \\
\text { 2014a) }\end{array}$ & \\
\hline U-NCTS-3 & $\begin{array}{l}\text { - Moderate to high-amplitude } \\
\text { reflectors } \\
\text { - } \quad \text { Folded \& faulted }\end{array}$ & $\begin{array}{l}\text { Zealandia U3 } \\
\text { (Bache et al., } \\
\text { 2014a) }\end{array}$ & \\
\hline
\end{tabular}




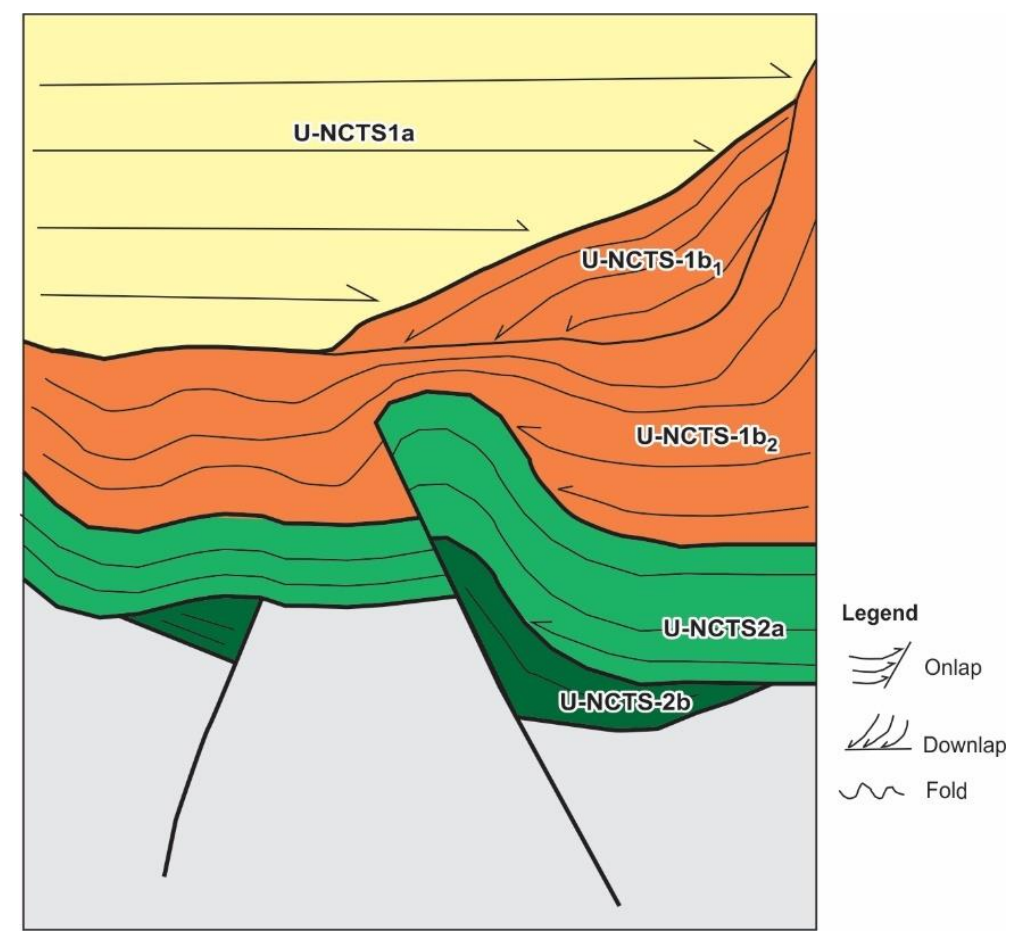

Figure 3.16. Seismic stratigraphy cartoon for southern New Caledonia Trough (NCTS).

\subsection{1 $\underline{\text { U-NCTS-3 }}$}

U-NCTS-3 has chaotic discontinuous reflectors or transparent seismic facies, but dipping reflectors with moderate continuity are locally present (Table 3.4) (Bache et al., 2014a, Etienne et al., 2018, Sutherland et al., 2010, Collot et al., 2009). U-NCTS-3 is faulted and folded and truncated at its top (RU2 regional unconformity) (Bache et al., 2014a, Etienne et al., 2018).

\subsubsection{U-NCTS $2 b$}

U-NCTS-2b is characterised by high to moderate amplitude continuous reflectors. U-NCTS-2b has basal onlap termination of continuous or semi-continuous subparallel reflectors and is faulted at its base (Table 3.4 \& Fig. 3.16) (Bache et al., 2014a, Sutherland et al., 2010, Etienne et al., 2018). U-NCTS-2b onlaps basement and is in turn onlapped by U-NCTS-2a (Fig. 3.16). U-NCTS-2b has a thin section $<0.5 \mathrm{~s}$ TWT. 


\subsubsection{U-NCTS 2a}

U-NCTS-2a has moderate to high amplitude continuous subparallel reflectors (Table 3.4) (Bache et al., 2014a, Etienne et al., 2018, Sutherland et al., 2010). U-NCTS-2a onlaps underlying strata U-NCTS-2b and basement (RU2 regional unconformity) (Fig. 3.2, 3.16 \& 3.26). U-NCTS-2a is locally deformed by reverse faulting (Fig. 3.16) (Bache et al., 2014a, Collot et al., 2009, Etienne et al., 2018). U-NCTS-2a has a few narrow diffractive intrusions along TL-1 line. Thickness is about 1 to $1.3 \mathrm{~s}$ TWT at Site U1509 and farther north near Site U206 (Fig. 3.17A), and the thickness of U-NCTS-2a is up to $2.5 \mathrm{~s}$ TWT at the edge of Deepwater Taranaki Basin (Collot et al., 2016).

\subsubsection{U-NCTS-1b}

U-NCTS-1b has moderate to high amplitude continuous seismic reflectors that either onlap or downlap onto U-NCTS-2a. (Table 3.4 \& Fig. 3.16) (Sutherland et al., 2010, Etienne et al., 2018). U-NCTS-1b onlaps its basal surface (RU1) at the basin flank. UNCTS- $1 b$ is divided into two sub-units ( $U 1 b_{1}$ and $U 1 b_{2}$ ) based on stratal stacking pattern. U-NCTS-1 $b_{1}$ has basal downlap interpreted as prograding sediment that resulted from erosion or transgressive wave ravinement of West Norfolk Ridge (Fig. 3.25), which is cut by a flat planation surface (Sutherland et al., 2010, Orr et al., 2020). U-NCTS-1 $b_{2}$ is growth strata and onlaps folds and faults and interpreted as syn-tectonic (Etienne et al., 2018). U-NCTS-1b has a thickness of 0.1 to $1 \mathrm{~s}$ TWT (Fig. 3.17B).
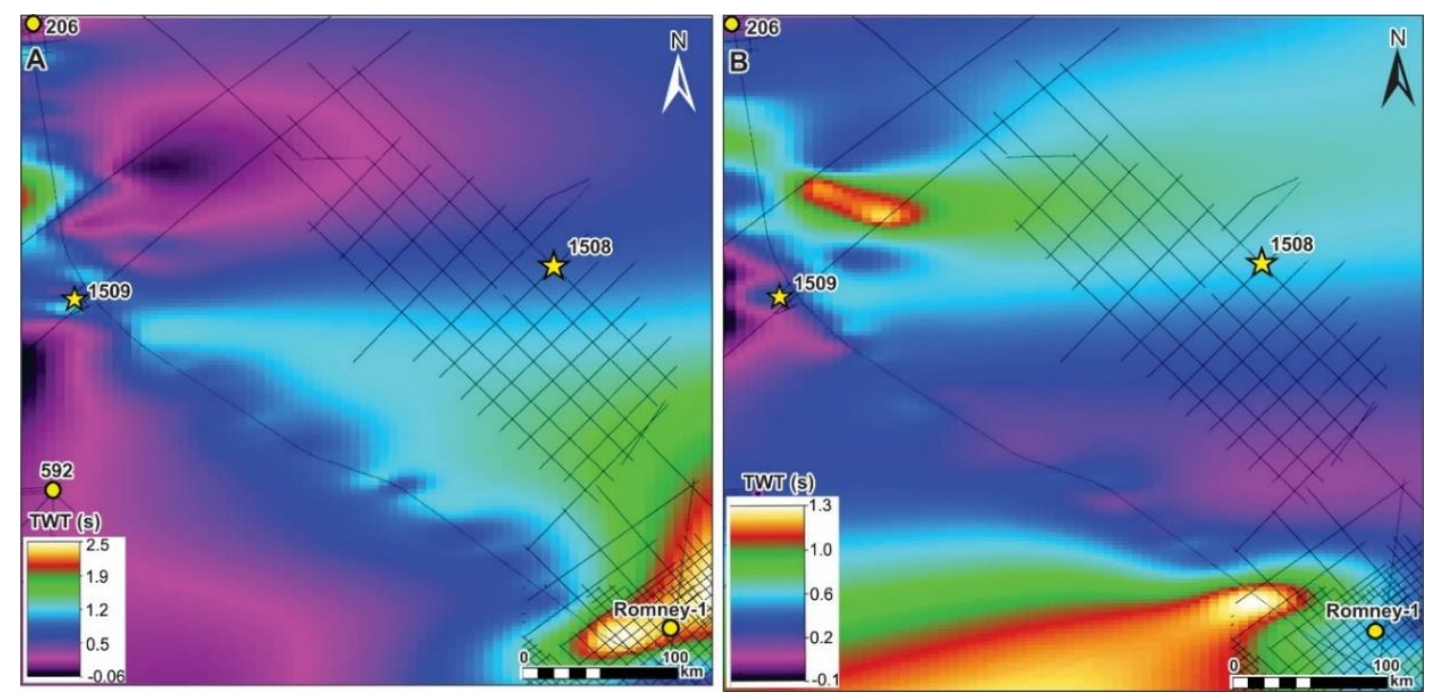

Figure 3.17. Unit thicknesses in second two-way time (TWT) in NCTS and REIN, (A) U-NCTS-U2 (B) U-NCTS-1b. 


\subsubsection{U-NCTS-1a}

U-NCTS-1a has moderate amplitude horizontal continuous reflectors that onlap UNCTS-2 $a$ and U-NCTS- $1 b$ that are interpreted as turbidites filling the axis of the trough (Table 3.4 \& Fig. 3.16) (Sutherland et al., 2010). U-NCTS-1a has a blanket of semicontinuous low-amplitude reflectors on the flank of the trough interpreted as pelagic drape. The thickness of U-NCTS-1a is up to $1.3 \mathrm{~s}$ TWT, and is thinner (0-0.4 s TWT) on the Lord Howe Rise slope (Fig. 3.25) (Etienne et al., 2018).

\subsection{Northern New Caledonia Trough (NCTN)}

The interpretation of stratigraphy of northern New Caledonia Trough (NCTN) is described and interpreted based on seismic reflection data tied to IODP borehole U1507 (Sutherland, 2019b) (Table 3.5, Fig. 3.19, Fig. 20 \& Fig. 4.23). I created a seismic stratigraphy cartoon (Fig. 3.18) based on seismic reflection interpretation that is presented in Figures 3.19, 3.20 and 4.23. The seismic stratigraphy of NCTN is connected with other regions (e.g., FWAY, LHRN and down to U206) using the TECTA seismic survey (Figs. $1.1 \&$ 3.19). I used Zealandia-wide megasequence nomenclature of Bache et al. (2014) to define three seismic units in NCTN: U-NCTN-1a, U-NCTN-U1b, and U-NCTN-2a (Table 3.5 \& Fig. 3.18).

Table 3.5. NCTN Seismic units characteristics.

\begin{tabular}{|c|c|c|c|}
\hline $\begin{array}{c}\text { Seismic } \\
\text { Units }\end{array}$ & Seismic pattern \& key features & $\begin{array}{c}\text { Previously } \\
\text { named }\end{array}$ & References \\
\hline U-NCTN-1a & $\begin{array}{l}\text { - Low to moderate amplitude } \\
\text { continuous reflectors } \\
\text { - Sub-horizontal continuous } \\
\text { reflector, } \\
\text { - Onlap }\end{array}$ & $\begin{array}{l}\text { Zealandia } \\
\text { U1a (Bache et } \\
\text { al., 2014a) }\end{array}$ & \multirow[t]{3}{*}{$\begin{array}{l}\text { (Bache et al., 2014b, } \\
\text { Sutherland, 2019b, } \\
\text { Sutherland et al., } \\
\text { 2020) }\end{array}$} \\
\hline U-NCTN-1b & $\begin{array}{ll}\text { - } & \text { High to low amplitude } \\
\text { continuous reflectors } \\
\text { - } \quad \text { Downlap } \\
\text { - } \quad \text { Onlaps } \\
\text { - } \quad \text { Syn-folded }\end{array}$ & $\begin{array}{l}\text { Zealandia } \\
\text { U1b (Bache et } \\
\text { al., 2014a) }\end{array}$ & \\
\hline U-NCTN-2a & $\begin{array}{ll}\text { - } & \text { Continuous reflectors } \\
\text { - } & \text { Small Faulting } \\
\text { - } & \text { Slightly/locally folded }\end{array}$ & $\begin{array}{l}\text { Zealandia } \\
\text { U2a (Bache et } \\
\text { al., 2014a) }\end{array}$ & \\
\hline
\end{tabular}




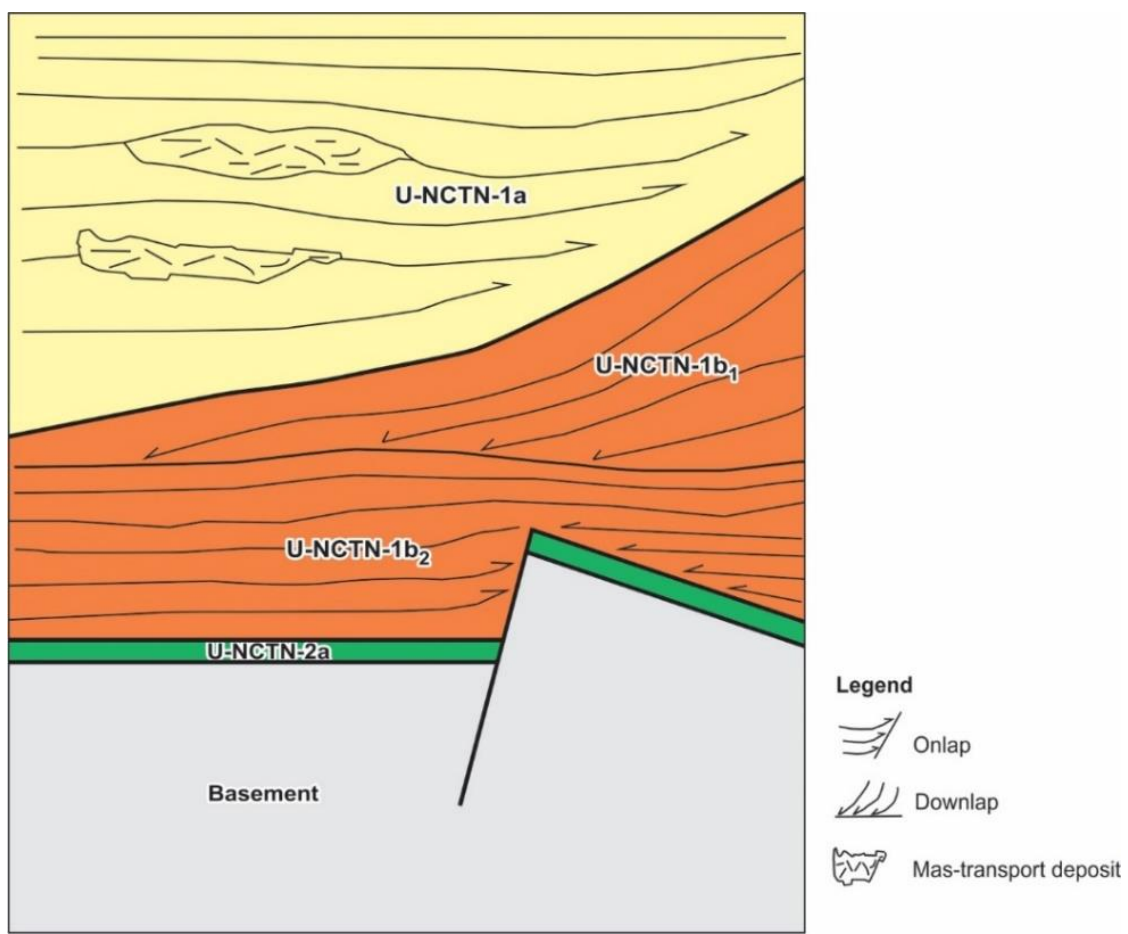

Figure 3.18. Seismic stratigraphy cartoon for northern New Caledonia Trough (NCTN).

\subsection{1 $\underline{\text { Basement }}$}

U-NCTN-3 contains isolated discontinuous high amplitude reflectors that could be volcanic intrusions or faults, but no coherent reflection packages of possible sedimentary origin were identified (Fig. $3.18 \& 3.19$ ).

\subsubsection{U-NCTN-2a}

U-NCTN-2a has continuous high amplitude reflectors (Table 3.5 \& Fig. 3.12, 3.18, $3.19 \& 3.20$ ) (Sutherland, 2019b). U-NCTN-2a is cut by small faults and apparent volcanic intrusions (Fig. 3.19). U-NCTN-2a is thin ( $<0.4 \mathrm{~s}$ TWT, Fig. 3.20A) near Site U1507, and is underlain by and onlaps flat basement (Fig. 3.12, 3.18, 3.19 \& 3.20). UNCTN-2a becomes thick (>0.5 s TWT) further west through Fairway Basin (Fig. 3.15B\& 3.21A) and south near Site U206 (Fig. 3.14). U-NCTN-2a is weakly deformed by minor normal faulting near Site U1507 (Fig. 3.18 \& 3.19), causing local tilting of reflectors (Fig. 3.19). U-NCTN-2a is overlain by U-NCTN-1b which are sourced from lateral sediment supply coming from adjacent ridges (Fig. 3.18). U-NCTN-2a continuity is interrupted by Fairway (FWAY) Ridge, which is a basement high structure that can be traced from a seabed ridge into a basement high that is onlapped by subsurface strata. 

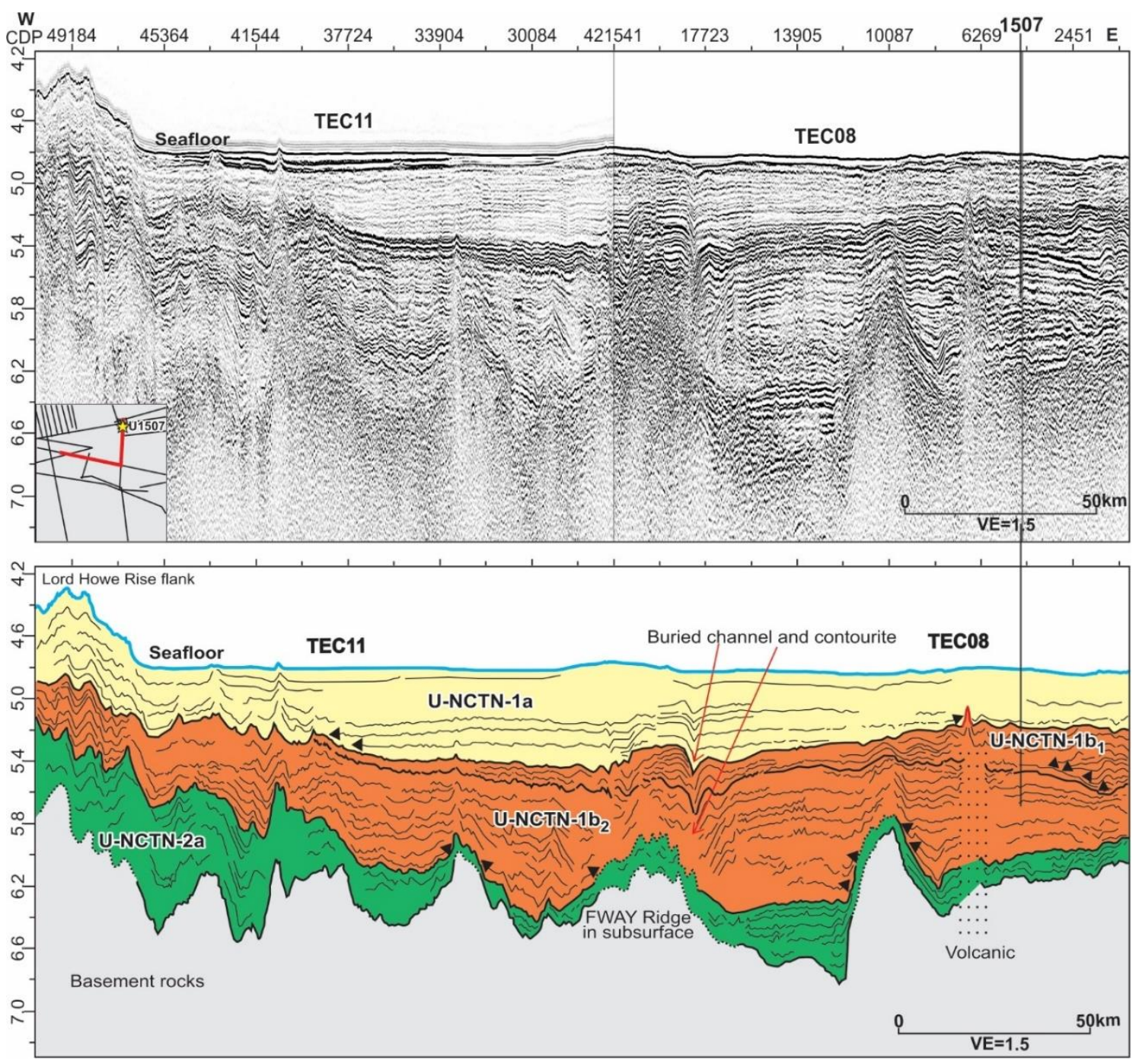

Figure 3.19. Intersection seismic reflection line TEC 11 and TEC 08 across NCTN (above) and sketch of stratigraphy (below). Note that the thickness of Seismic Unit $1 \mathrm{~b}$ (U1b) throughout NCTN is relatively large, and Seismic Unit 2a (U2a) is relatively thinner than in FWAY Basin.

\subsubsection{U- NCTN-1b}

U-NCTN-1b is characterised by onlap and downlap termination with continuous to semi-continuous moderate amplitude reflectors (Table 3.5, Fig. 3.18, $3.19 \&$ \& 3.20) (Sutherland, 2019b). U-NCTN-1b has two sub-units U1b 1 and U1b 2 , based on their seismic character (Fig. 3.19). These two sub-units are interpreted as having been deposited during times of active uplift and erosion, which is similar to inferences concerning $\mathrm{U} 1 \mathrm{~b}$ in the NCTS and REIN regions. U-NCTN-1 $\mathrm{b}_{1}$ shows onlap and downlap onto U-NCTN-1 $b_{2}$, which in turn onlaps U-NCTN-2a (Fig. 3.18, 3.19 \& 3.20). U-NCTN$1 b_{1}$ contains volcanoclastic deposits at Site U1507 with a variety of sedimentary facies indicative of various gravity-flow processes (Sutherland, 2019b). The thickness of UNCTN-1b ranges from 0.7 to $1.2 \mathrm{~s}$ TWT (Fig. 3.21B). 


\subsubsection{U- NCTN-1a}

U-NCTN-1a has continuous to semi-continuous moderate amplitude reflectors and chaotic layers up to $20 \mathrm{~km}$ across that are interpreted as debris flows (Table 3.5, Fig. 3.20 \& Fig. 4.23) (Sutherland, 2019b). U-NCTN-1a onlaps U-NCTN-1b 1 (Fig. 3.18, 3.19 \& 3.20). U-NCTN-1a contains scar failures on the basin margins that indicate mass failures and collapse into the trough. U-NCTN-1a has a thickness of $<0.9 \mathrm{~s}$ TWT.

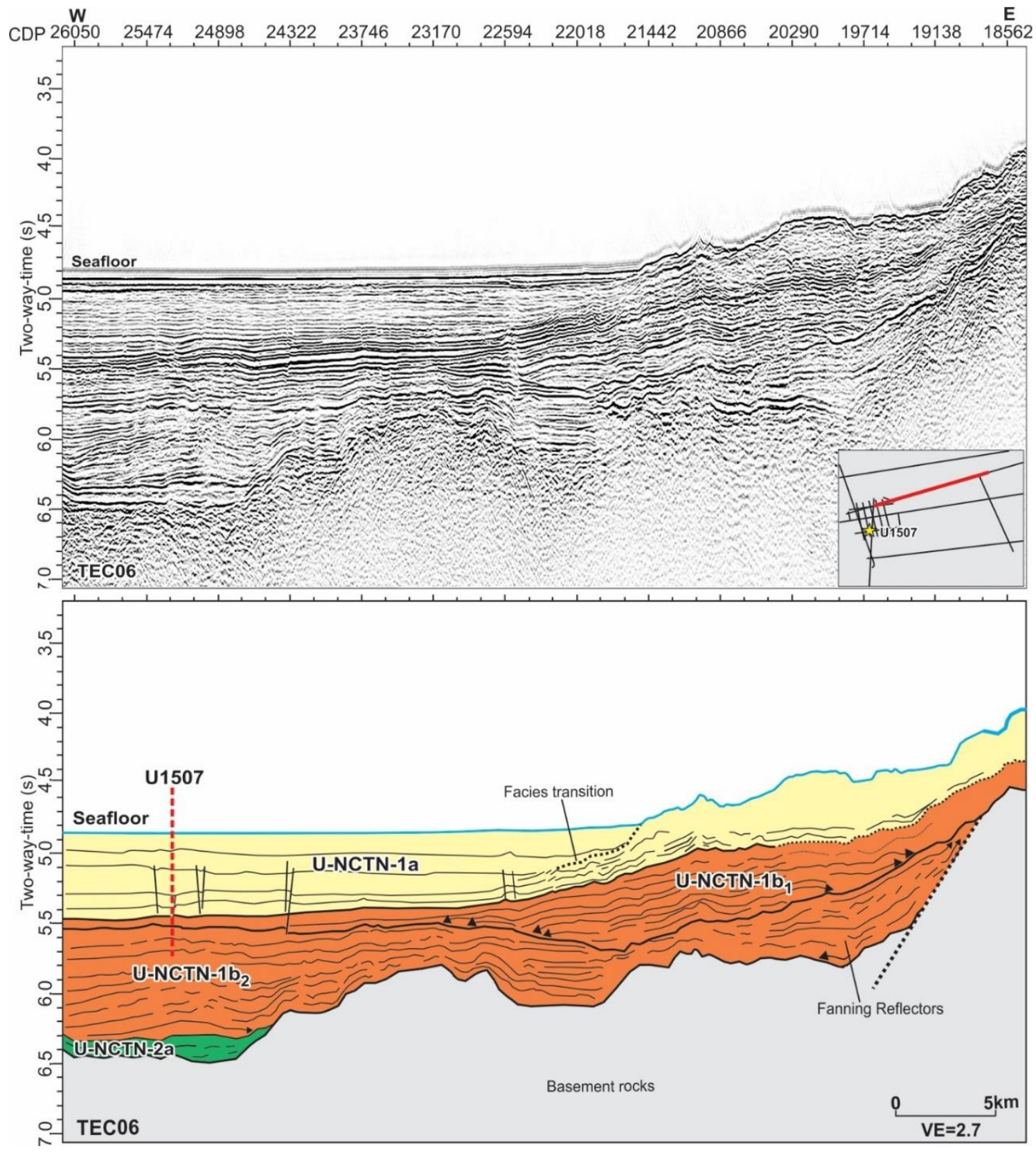

Figure 3.20. TEC06 seismic reflection image (above) and sketch interpretation of Seismic Units U-NCTN$1 \mathrm{a}, \mathrm{U}-\mathrm{NCTN}-1 \mathrm{~b}$ and U-NCTN-2a (below). U1b is characterised by downlap and onlap termination. 

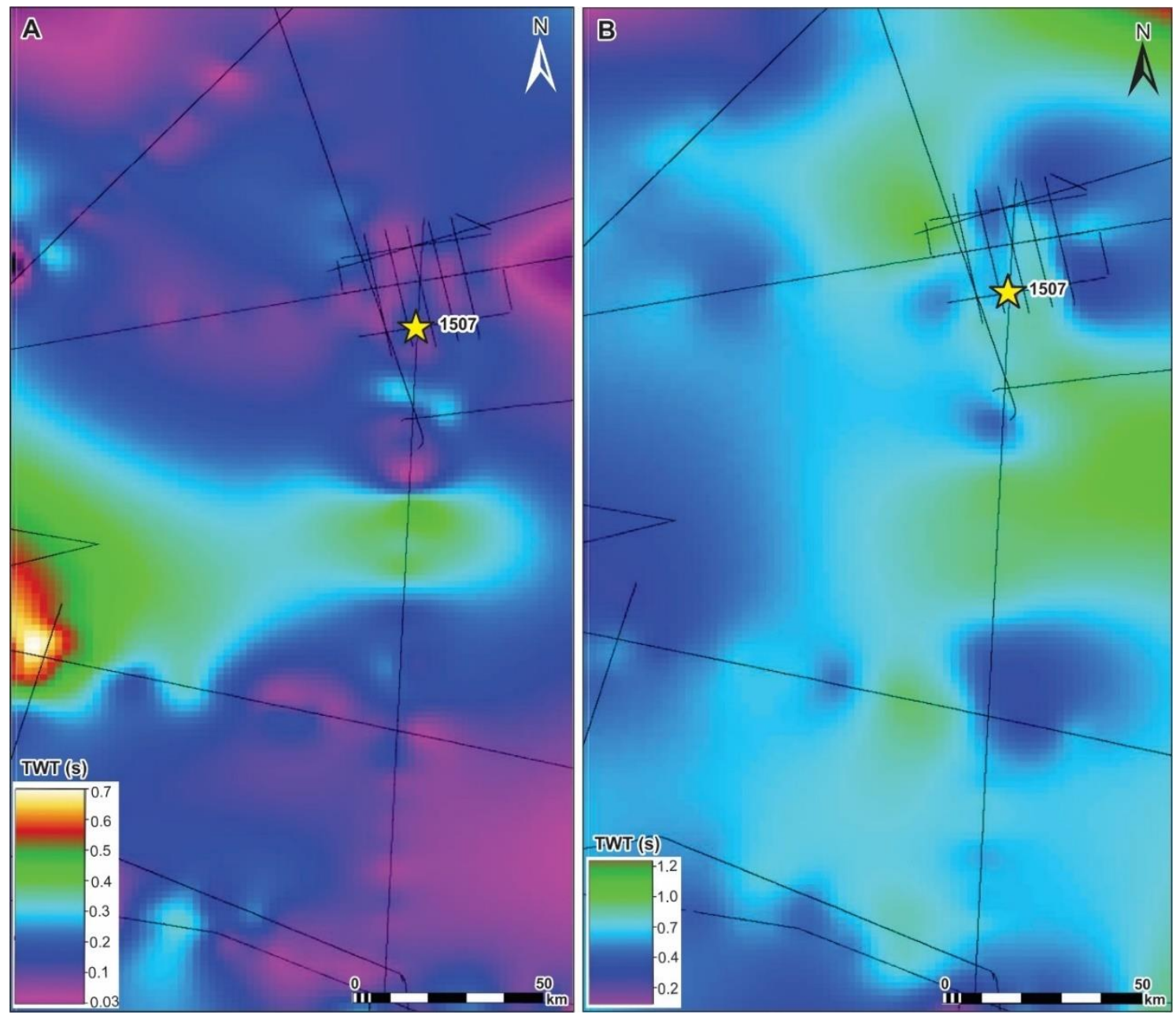

Figure 3.21. Unit thickness in second two-way time (TWT) in NCTN, (A) U-NCTN-2a, (B) U-NCTN-1b. 


\subsection{Reinga Basin (REIN)}

Previous workers defined seismic stratigraphic units (Bache et al., 2012a, Bache et al., 2012b, Herzer et al., 1997, Orr et al., 2020, Bache et al., 2014a) (Table 3.6). Broad correlation to horizons indicated in Bache et al. (2012 a, b) led to modification of their nomenclature and hence I define seismic units: U-REIN-1 (U1a \& U1b), U-REIN-2 (U2a \& U2b) and U-REIN-3 (Table 3.6 \& Fig. 3.22). The cartoon in Figure 3.22 shows the general stacking pattern and Table 3.6 compares the seismic stratigraphic framework with previous work (Bache et al., 2012a, Bache et al., 2012b, Herzer et al., 1997, Orr et al., 2020, Bache et al., 2014a).

Table 3.6. REIN seismic unit characteristics.

\begin{tabular}{|c|c|c|c|}
\hline $\begin{array}{l}\text { Seismic } \\
\text { Units }\end{array}$ & $\begin{array}{c}\text { Seismic pattern \& key } \\
\text { features }\end{array}$ & Previously named & References \\
\hline U-REIN-1a & $\begin{array}{l}\text { - Sub-horizontal surface } \\
\text { associated with polygonal } \\
\text { faults in some places } \\
\text { - Onlaps }\end{array}$ & $\begin{array}{l}\text { Neo-4, Neo-2,3 \& Neo-1, } \\
\text { (Herzer et al., 1997); } \\
\text { Seismic Unit U5, U6, U7 \& } \\
\text { U8 (Bache et al., 2012a); } \\
\text { Zealandia U1a (Bache et } \\
\text { al., 2014a); U9 (Orr et al., } \\
\text { 2020) }\end{array}$ & \multirow{5}{*}{$\begin{array}{l}\text { (Bache et } \\
\text { al., 2014a, } \\
\text { Bache et al., } \\
\text { 2012a, Baur } \\
\text { et al., 2014, } \\
\text { King and } \\
\text { Thrasher, } \\
\text { 1996, Orr et } \\
\text { al., 2020) }\end{array}$} \\
\hline U-REIN-1b & $\begin{array}{ll} & \text { Onlaps } \\
\text { - } & \text { Downlaps } \\
\text { - } & \text { Strongly deformed }\end{array}$ & $\begin{array}{l}\text { Pal-1 \& P1 (Herzer et al., } \\
\text { 1997); Seismic Unit U4-U5 } \\
\text { (Bache et al., 2012a); } \\
\text { Zealandia U1b (Bache et } \\
\text { al., 2014a, Orr et al., 2020) }\end{array}$ & \\
\hline U-REIN-2a & $\begin{array}{l}\text { - Strongly deformed, folded } \\
\text { - Erosional truncations, } \\
\text { unconformity unit } \\
\text { - Onlaps }\end{array}$ & $\begin{array}{c}\text { Cre-1 \& Pal-2 (Herzer et } \\
\text { al., 1997); Seismic Unit U2- } \\
\text { U4 (Bache et al., 2012a); } \\
\text { Zealandia U2a (Bache et } \\
\text { al., 2014a) }\end{array}$ & \\
\hline U-REIN-2b & $\begin{array}{ll} & \text { High amplitude, subparallel } \\
& \text { reflectors } \\
\text { - } & \text { Onlap termination } \\
\text { - } & \text { Folded then truncation by a } \\
& \text { planation surface in some } \\
\text { places } \\
\text { - } \\
\text { - Inversion } \\
\text { Normal faults, fanning } \\
\text { growth strata }\end{array}$ & $\begin{array}{l}\text { Cre-1 (Herzer et al., 1997); } \\
\text { Seismic Unit U1 (Bache et } \\
\text { al., 2012a); Zealandia U2b } \\
\text { (Bache et al., 2014a) }\end{array}$ & \\
\hline U-REIN-3 & $\begin{array}{ll}\text { - } & \text { Divergent seismic reflectors } \\
\text { - } & \text { Normal faults }\end{array}$ & $\begin{array}{c}\text { Zealandia U3 (Bache et al., } \\
\text { 2014a) }\end{array}$ & \\
\hline
\end{tabular}




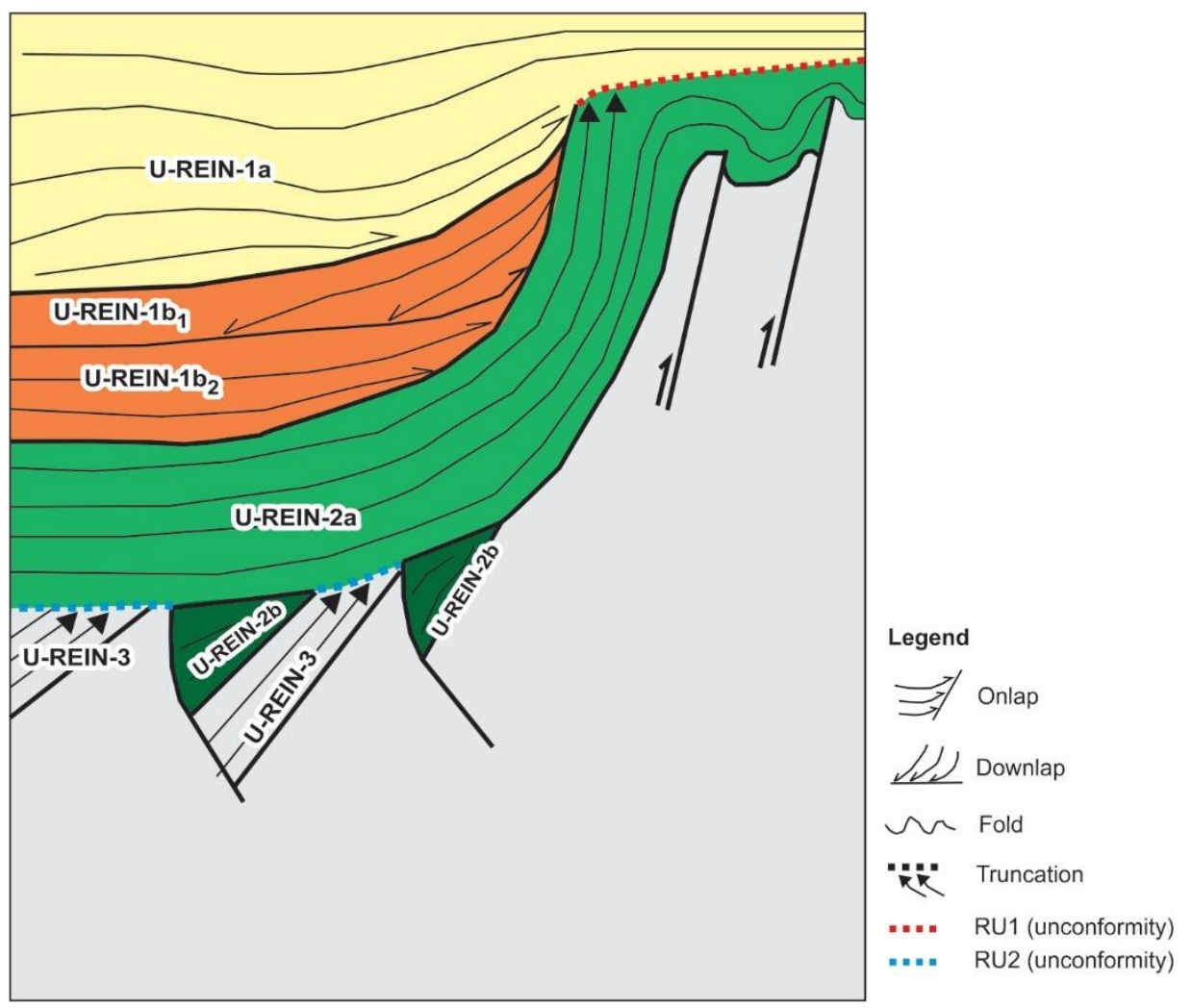

Figure 3.22. Seismic stratigraphy cartoon for Reinga Basin (REIN).

\subsubsection{U-REIN-3}

U-REIN-3 has variable amplitude continuous reflectors that are parallel and with high to moderate continuity, stratified and folded (Table $3.6 \& 3.23$ ). U-REIN-3 is characterised by erosional truncations at its top and onlapping reflectors above (Table 3.6, Fig. 3.22) (Bache et al., 2014a, Bache et al., 2012a, Herzer et al., 1997). This unconformity (RU2) is overlain by younger successions with less deformed seismic reflectors (U-REIN-2a and U-REIN-2b) (Fig. 3.22) (Bache et al., 2012b). 


\subsubsection{U-REIN-2b}

U-REIN-2b corresponds to syn-rift half-grabens fill, as interpreted by Bache et al. (2012a), Bache et al. (2012b), and Herzer et al. (1997) (Fig.3.22 \& 3.23). U-REIN-2b corresponds to Seismic Unit U1 of Bache et al. (2012b). U-REIN-2b has basal onlap terminations with continuous or semi-continuous reflectors, fanning reflectors, and is typically faulted at its base (Fig. 3.23). U-REIN-2b has thickness $<0.7 \mathrm{~s}$ TWT near Site U1508.
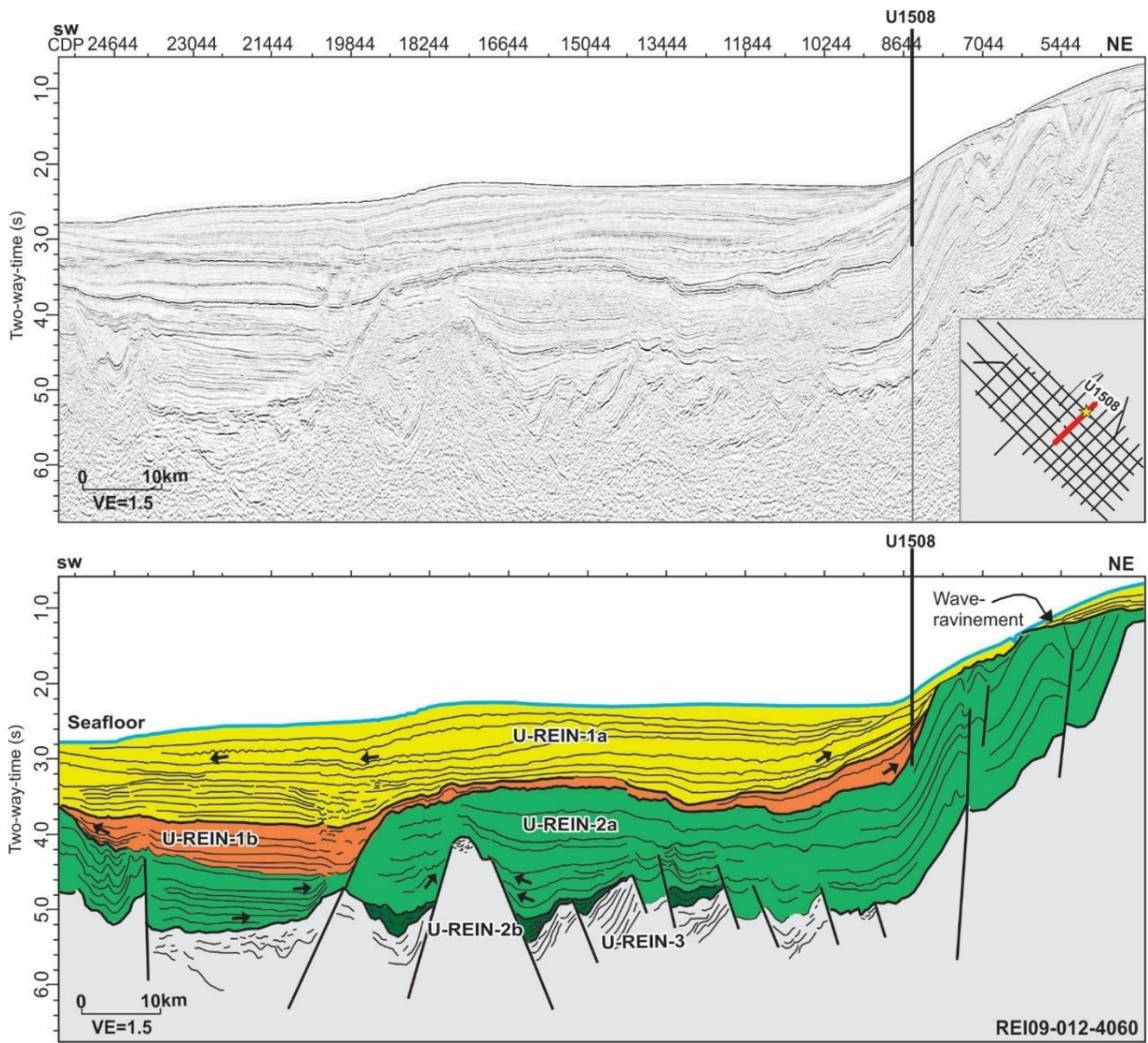

Figure 3.23. REIN09-012 seismic reflection image (above) and sketch interpretation of Seismic Units UREIN-1a, U-REIN-1b, U-REIN-2a, U-REIN-2b and U-REIN-3 (below). Black arrows are onlaps (adapted from Bache et al., 2014; Orr et al., 2020). 


\subsubsection{U-REIN-2a}

U-REIN-2a is locally affected by later folding or reverse faulting (Bache et al., 2014a, Bache et al., 2012a). Deposition resulted in onlap against basement highs created by earlier extensional faulting (Table 3.6, Fig. $3.22 \&$ 3.23) (Bache et al., 2012a, Bache et al., 2012b, Herzer et al., 1997).

Bache et al. (2012) nomenclature of this unit is Seismic Unit U2 to U4. Seismic Unit U2 is characterised by sub-parallel reflectors with onlaps. Seismic Unit U3 has parallel continuous reflectors that are strongly folded in the NW, and the thickness is about 1.0 to $1.2 \mathrm{~s}$ TWT the Northland Basin to the SE. Seismic Unit U4 has folded parallel reflectors in eastern Reinga Basin and is strongly folded in the NW and less folding in south Northland Basin (Bache et al., 2012a). Seismic Unit U4 has a thickness of about at 0.2 to 0.4 s TWT (Bache et al., 2012a).

U-REIN-2a has parallel folded reflectors, onlaps topographic highs, is truncated by RU1, and overlain by U-REIN-1a (Fig. 3.22 \& 3.23). Near Site U1508, discontinuous reflectors of U-REIN-2a are eroded near volcanic and structural highs, and at basin margins (Fig. 3.22 \& 4.29A) (Orr et al., 2020, Bache et al., 2012a). U-REIN-2a ranges in thickness up to $2.1 \mathrm{~s}$ TWT (Figure 3.24A).
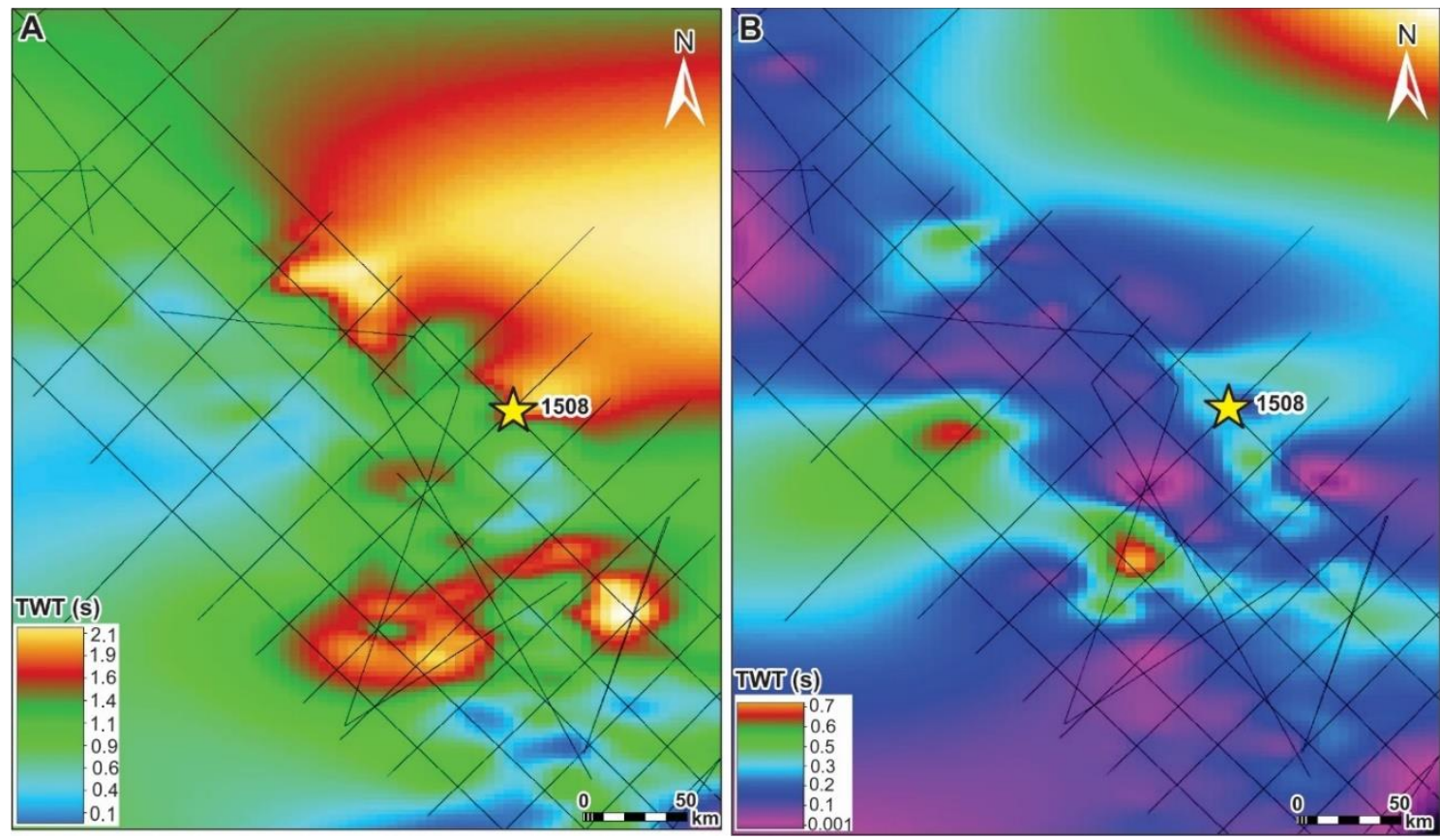

Figure 3.24. Unit thicknesses in second two-way time (TWT) in REIN basin near Site U1508, (A) U-REIN2a, and (B) U-REIN-1b. 


\subsubsection{U-REIN-1b}

U-REIN-1b has high-amplitude continuous reflectors, fanning, downlap and onlap (Table 3.6, Fig. $3.22 \&$ 3.23) (Bache et al., 2014a, Bache et al., 2012a, Sutherland, 2019c, Orr et al., 2020). U-REIN-1b is divided into two sub-units U-REIN-1 $b_{1}$ and U-REIN-1 $b_{2}$, based on seismic character. U-REIN-1 $b_{1}$ is characterised by downlap, and U-REIN-1 $b_{2}$ onlaps folded U-REIN-2a reflectors (Fig. 3.22 \& 3.23). U-REIN-1b 1 contains volcanic detritus that relates to initial arc volcanism near North Island. U-REIN-1b corresponds to Seismic Unit U4-U5 of Bache et al. (2012b) (Fig. 4.28 \& 4.29). Seismic Unit U5 is characterised by high-amplitude continuous reflectors with distinctive basal onlap surface, slightly deformed to undeformed. Seismic Unit U5 separates less deformed subhorizontal reflectors from underlying folded U4 (Orr et al., 2020, Bache et al., 2012a). Seismic Unit U5 has a thickness of $<0.2$ s TWT (Orr et al., 2020). The thickness of UREIN-1b ranges from 0.1 to $0.7 \mathrm{~s}$ TWT (Fig. 3.24B).

\subsubsection{U-REIN-1a}

U-REIN-1a has continuous variable-amplitude reflectors (Table 3.6, Fig. $3.22 \&$ 3.23). U-REIN-1a has complex internal bedforms and is associated with small-offset polygonal faults (Fig. 3.23, 4.28 \& 4.29). U-REIN-1a contains four Seismic Units (U6, U7, U8, and U9 of Bache et al. (2012) and Orr et al. (2020)) (Table 3.6). Herzer et al. (1997) defined four-units, namely Neo-4, Neo-2, 3, and Neo-1 (Table 3.6). U-REIN-1a is variable in thickness: thin near Site U1508 and thick further from the basin margin (Fig. 4.28). The thickness ranges from $<0.2$ to $0.6 \mathrm{~s}$ TWT (Orr et al., 2020). 


\subsection{Interpretation and discussion}

Folded, faulted, and truncated Seismic Unit U3 is overlain by less deformed seismic reflectors with onlap relationship (Seismic Units U2a and U2b). Onlap and downlap of Seismic Snit U1b onto unconformity RU1 at the top of U2 occurred in many places across northern Zealandia. However, seismic stratigraphy observed in northern Zealandia has little borehole control. DSDP boreholes (U206, U207 and U208) have penetrated Late Cretaceous to Eocene strata (Burns et al., 1973a, Burns et al., 1973b). IODP drilling data (U1509) in NCTS penetrated to Cretaceous, and to Eocene in LHRN (U1506), NCTN (U1507), REIN (U1508) and LHRS (U1510). Hence, dredged rock samples, DSDP and IODP sites can be tied to seismic data to map and interpret seismic-stratigraphic relationships across northern Zealandia.

\subsubsection{Geology relationship across northern Zealandia}

Basement in New Zealand contains a series of linear terranes that are approximately parallel with the ancient Gondwana margin (Mortimer, 2004, King, 2000b, King and Thrasher, 1996, Uruski et al., 2003). The basement comprises metamorphosed igneous and volcaniclastic sediments of Paleozoic and Mesozoic ages, and a relic arc called the Median Batholith or Median Tectonic Zone (Mortimer et al, 1997). Petroleum wells near the coast of New Zealand also place some control on the distribution of basement terranes, e.g. the Wainui-1 well penetrated Paleozoic Takaka Terrane (metamorphosed siliceous sandstone) (SBPT, 1982).

The Murihiku Supergroup is inferred in the REIN-Northland Basin based on well and dredge sampling (Mortimer et al., 2009), and in southeast Zealandia in the Great South Basin based on seismic reflectors (Cook et al., 1999b). The Seismic Unit U3 is characterised by folded strata, and erosional truncations that I interpret as Murihiku Supergroup, similar to exposed geology on the margins of Northland and Great South Basin. These interpretations are supported by the Waka Nui-1 well, which penetrated late Jurassic-early Cretaceous Murihiku Supergroup volcaniclastic coal measures (Mortimer et al., 2009). In New Caledonia, the Teremba Terrane contains Late Permian to Mid Jurassic calc-alkaline volcanic rocks and volcaniclastic rocks with similarities in age and lithology to the Murihiku Supergroup (Cluzel et al., 2012, Campbell et al., 1985). $120 \mathrm{~km}$ 
NW of Waka Nui-1, Early Cretaceous dinoflagellates sampled at onshore Waimamaku-2 are interpreted as Murihiku Supergroup (Hornibrook et al., 1976). In NCTS, Seismic Unit U3 is unsampled but may contain equivalents of Muhiriku Supergroup (Bache et al., 2014a; Bache et al., 2012a). The Murihiku Supergroup onshore in New Zealand contains Early Triassic to Late Jurassic marine and non-marine sandstone and mudstone, including basal Late Permian sandstone (Campbell et al., 2003).

Norvick et al. (2008) suggest that a Lower-Middle Jurassic pre-rift sequence might exist on Lord Howe Rise that is an equivalent of the Late Jurassic Walloon Coal Measures and Koukandowie Formation of Queensland. The Walloon Coal Measures were deposited in fluvial and lacustrine or swampy environments in the Clarence-Moreton and Surat basins (Ingram et al., 1996). Hydrogen-rich coals of the Walloon Coal Measures were also deposited in Surat Basin. In northern Queensland in the Laura and Carpentaria basins, the latest Jurassic-Neocomia Gilbert Formation contains lagoonal to marginal marine strata (Turner et al., 2009).

In south-eastern Australia, the Late Jurassic and Early Cretaceous rift-related volcanoclastic Strzelecki Group of the Gippsland Basin is also a possible correlation of U3. Gippsland Basin contains coal measures and lacustrine facies of the Jurassic Beds that deposited during the early stages of the Otway Rift Phase (Norvick et al., 2001). This rift occurred through the Early Cretaceous, synchronous with deposition of the Strzelecki Group. A Campanian (100-90 Ma) unconformity in Gippsland is overlain by Emperor and Golden Bay subgroups deposited in the Late Cretaceous (Norvick et al., 2001, Uruski et al., 2003). Non-marine units are found in eastern Australia basins, and marine strata are unknown.

North of Australia, Marine Triassic-Jurassic strata are found in the onshore TimorLeste and offshore Bonaparte Basin (Charlton, 2002, Audley-Charles, 1968). Triassic radiolarian wackestone interbedded with shale of the Aitutu Formation was deposited in marine conditions (Audley-Charles, 1968). The Gondwana Jurassic in onshore Timor contains carbonate-platform facies and shelf facies overlain by Cretaceous deep-water pelagic deposits (Haig et al., 2019). The Early to Middle Jurassic Plover Formation of Bonaparte Basin consists of sandstones and shale (Mory, 1991, Jules et al., 2015). Early to Middle Jurassic sandstones and shale (Plover Formation) are non-marine to marginal 
marine and overlie Middle Jurassic shallow marine sandstone (Robinson, 2012, Jules et al., 2015, Mory, 1991).

Further northeast of Australia, marine clastic sediments are known in Papua New Guinea (Brown et al., 1979). The Papuan Basin in PNG contains Mesozoic sediments deposited on Palaeozoic continental basement rocks (Waples and Wulff, 1996, Ahmed A. S. et al., 1988). The Jurassic marine shelf clastic sediments (Imburu Formation of the Papuan Basin) was deposited during inundation of the margin (Ahmed A. S. et al., 1988). Middle to Upper Jurassic clay-rich marine source rocks contain terrigenous higher plant organic matter deposited under oxic condition (Ahmed et al., 2012, Waples and Wulff, 1996).

Marine Mesozoic strata are extensively developed in the offshore Bonaparte Basin and onshore Timor-Leste (Charlton, 2002; Mory, 1991; Robinson, 2012), and marine clastic sediments are known in Papua New Guinea (Brown et al, 1979). It is plausible that similar marine source rocks are imaged as Seismic Unit U3 in northern Zealandia.

Eastern Australia and Zealandia experienced widespread Mesozoic contractional uplift and subaerial erosion followed by rifting, subsidence, and relative sea-level rise during the Late Cretaceous to Eocene (Bache et al., 2014a, Sutherland et al., 2010). The result of this erosion is the RU2 unconformity (Bache et al., 2014a). Regionally, the products of this erosion and transgression caused deposition of a coal measuresandstone-mudstone sequence, overlain by fluvial, coastal, and shallow-marine sandstones (Bache et al., 2014a, King, 2000b, King and Thrasher, 1996). Lithostratigraphic correlation is possible between southeastern Australia (Golden Beach and Latrobe groups of Gippsland Basin), New Zealand (Pakawau and Kapuni groups of Taranaki Basin), and New Caledonia ("Formation à charbon" and "phtanites") (Norvick et al., 2001, King and Thrasher, 1996, Baur et al., 2014, Cluzel et al., 2010).

The lithostratigraphy of Seismic Unit U2b across northern Zealandia is inferred from geology relationships in the region. Seismic Unit U2b has never been sampled in the remote Zealandia offshore region, and comparison to New Zealand, New Caledonia and eastern Australia suggests the likely occurrence of fluvial sandstone, mudstone and coal, grading upwards to claystone associated with marine transgression (King and Thrasher, 1996, Collot et al., 2009, Cluzel et al., 2012, Campbell et al., 1985, Norvick et al., 2001). 
Cretaceous volcanic rocks, including pyroclastic deposits, flows and sills are observed onshore in New Caledonia (Maurizot and Vendé-Leclerc, 2009) and could be interbedded with U-FWAY-2b. A shallow-water fragment was associated with the $74 \pm$ 0.7 Ma latite dredge sample from Fairway Ridge (Higgins et al., 2011, Colwell et al., 2006). In NCTS, Seismic Unit U2b can be correlated with mid Cretaceous strata in Taranaki-Aotea Basin, where coal measures, alluvial plain, and marginal marine facies are sampled in wells (Uruski and Baillie, 2004, Collot et al., 2009, Strogen et al., 2017, King and Thrasher, 1996).

Based on comparison to eastern Australia, New Caledonia and New Zealand, Seismic Unit U2a in LHRN is probably dominated by Late Maastrichtian and Palaeocene claystone and chalk with chert (Site U208) (Fig. 5.5) (Burns and Andrews, 1973, Hashimoto et al., 2012). Cretaceous coaly sandstone rocks were dredged from the western flank of West Norfolk Ridge (Herzer et al., 1999), but it is not clear from which seismic unit. In NCTS (Seismic Unit U2a), Late Cretaceous marine claystone was sampled at Site U1509 (Fig. 5.7), and closer to Taranaki, (Sutherland et al., 2010, Collot et al., 2009) seismic interpretations tied to boreholes were used to map Late Cretaceous coal measures of Rakopi Formation (Baur et al., 2014). 


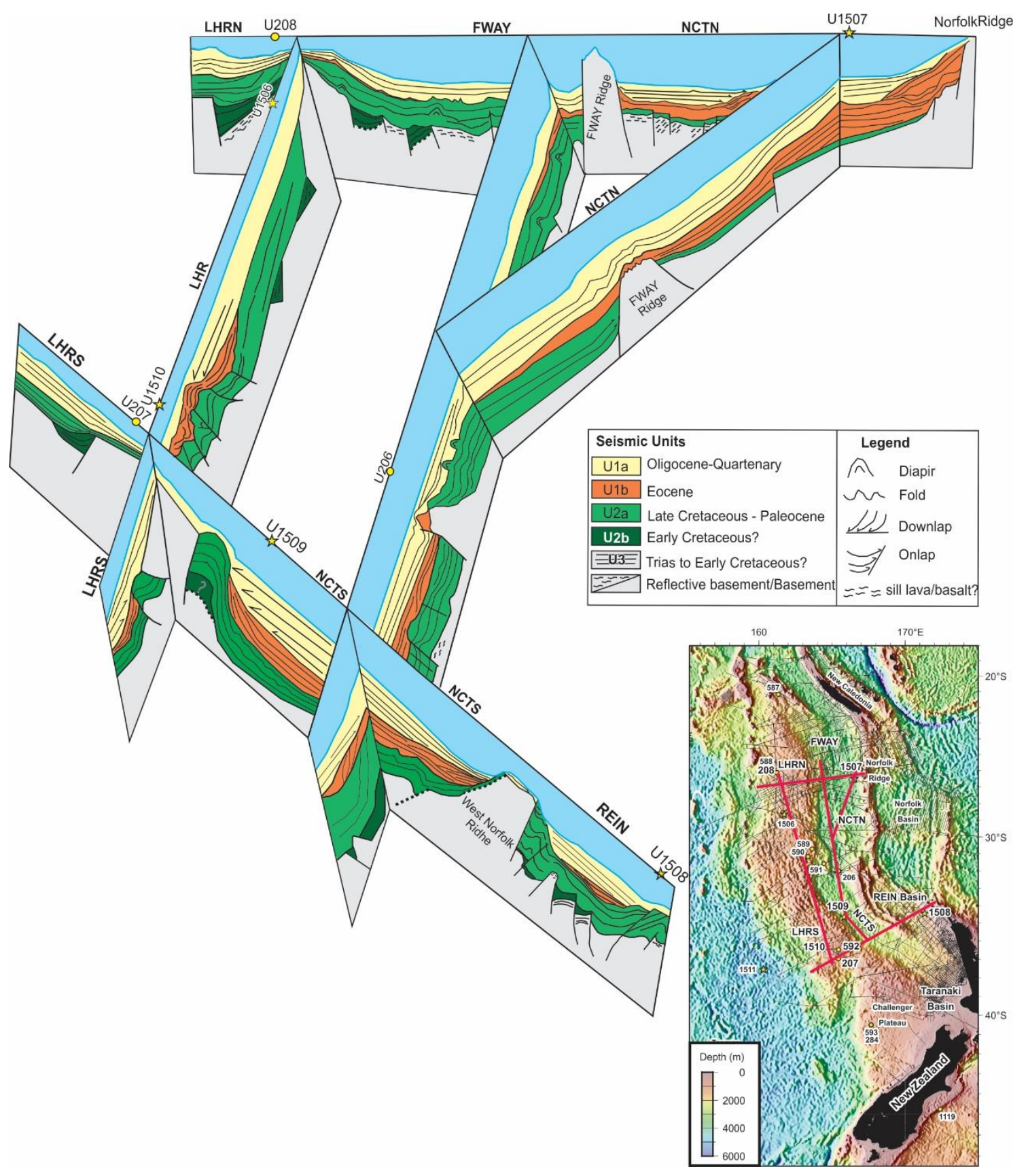

Figure 3.25. Cartoon diagram showing stratigraphy of seismic Units across northern Zealandia, based on this study and previous works (Auzende et al., 2000b, Bache et al., 2014a, Bache et al., 2012a, Collot et al., 2008, Collot et al., 2009, Exon et al., 2007, Lafoy et al., 1994, Rouillard et al., 2015, Sutherland et al., 2017, Sutherland et al., 2010). 


\subsubsection{Seismic Unit U3-U2b stratigraphic relationships}

The LHRN region is made up of a series of NNW trending horsts and grabens offset by NE trending accommodation (Willcox et al., 2001). LHRN is composed of pre-rift and basement which is speculated to contain several discrete terranes (Palaeozoic orogeny, pre-rift sedimentary and rift-precursor igneous rocks) and two Early Cretaceous syn-rift phases divided by Cenomanian uplift or inversion (rifting during eastern Gondwana breakup) (Higgins et al., 2015, Norvick et al., 2008a, Willcox and Sayers, 2001, Willcox et al., 2001).

Based on the seismic facies, Seismic Unit U3 recorded in LHRN (Table 3.2) is probably sedimentary strata (Fig. 3.9, $3.10 \& 3.25$ ). U-LHRN-3 may contain more than one unit (rift 1, pre-rift and basement). U-LHRN-3 (pre-rift) contains parallel to subparallel with high-moderate-amplitude continuous reflectors, stratified, uniformly tilted, and these characters indicate that U-LHRN-3 is sedimentary in origin.

U-LHRN-3 has been speculated to be Cretaceous in age (Hashimoto et al., 2010, Higgins et al., 2015), but U-LHRN-3 could be older than Cretaceous. U-LHRN-3 could be early Cretaceous or Jurassic or even could be Triassic-Permian in age. The seismic interpretation shows a significant break-in time, separating the rifting event (unconformity between U-LHRN-2 $\mathrm{b}_{2}$ and U-LHRN-2 $\mathrm{b}_{1}$ ) and hence U-LHRN-U2 $\mathrm{b}_{2}$ may also be classified as U-LHRN-U3 rather U-LHRN-2b (Fig. 3.8 \& 3.9). Further northeast of LHRN (near Site U1507), there is no convincing evidence that the older unit beneath U-NCTN-2a contains sedimentary strata (Fig. 3.19, $3.20 \&$ 3.25). The oldest sequence does not have continuous reflectors. Reflectors could be faults or volcanic intrusions. Further south in REIN (near Site U1508), U-REIN-3 is interpreted to contain the Murihiku Supergroup, which is supported by the Waka Nui-1 well. 


\subsubsection{Seismic Unit U2a-U1b stratigraphic relationships}

The stratigraphic relationship between Seismic Unit U2a and Seismic Unit U1b is defined based on seismic interpretation data, drilling and dredge samples. By comparing the sedimentary thickness of Seismic Unit U2a with the other five regions (Fig. 3.25), it is noteworthy that Seismic Unit U2a is a thin unit in NCTN and becomes thicker in FWAY, NCTS, and REIN. Seismic Unit U1b in NCTN is thicker (Fig. 3.19, 3.20 \& 3.21B) than other regions (Fig. 3.12, $3.19 \&$ 3.21B). The thickness of sediment is a signal of lateral sediment supply coming from the LHRN and Norfolk Ridges. These observations appear to be consistent through the south and southeast region, where the LHRS experienced subaerial erosion between 45 and 34 or 29 Ma, REIN 34 and 24 Ma and New Caledonia was after circa 34 Ma (Sutherland et al., 2020, Collot et al., 2008, Sutherland et al., 2017).

Seismic Unit U1b shows evidence of hiatus (on ridges) across the Eocene-Oligocene boundary, but this hiatus is not observed in NCTN. Site U1507 records no missing time across the Eocene-Oligocene boundary, but an unconformity exists in the adjacent LHRN region, where subaerial erosion occurred at about $50 \mathrm{Ma}$ at Site U1506. The reason a hiatus is not observed in NCTN is because Seismic Unit U1b in NCTN was located at a low point, where there was rapid sedimentation in the depocenter. LHRN was swept by current across a top that was shallow, and hence materials are deposited into the trough.

NCTS and REIN basins contain deformed Cenozoic strata and flat unconformities. In NCTS, Seismic Unit U2a is overlain by a mass-transport complex deposit due to slope oversteepening resulting in Seismic Unit U1b (Fig. 3.25) (Etienne et al., 2018, Poestma et al., 2009). Seismic reflectors at Site U1509 show that Seismic Unit U1b thins onto the western slope of the basin, where there is exposure of Seismic Unit U2a deformed strata (Fig. 3.25). Due to tectonic subsidence along the New Caledonia Trough axis, uplift and erosion occurred on the LHRN slope and West Norfolk Ridge, and formed subtle tilting, reverse faulting (Fig. 3.25, $4.11 \& 4.12$ ), and minor folding of Seismic Unit U2a strata (Sutherland, 2019b, Sutherland et al., 2010). In REIN basin, Eocene contraction occurred leading to deformation of U-REIN-2a (Bache et al., 2012a, Sutherland, 2019c). Folding and uplift occurred at 56-43 Ma along West Norfolk Ridge to create wave ravinement surfaces (Orr et al., 2020), and compression and reverse faulting in the east occurred at 39 to $34 \mathrm{Ma}$ (Sutherland et al., 2017). 


\subsection{Chapter summary}

I have reviewed and mapped the Bache et al. (2014) seismic-stratigraphic architecture framework of northern Zealandia, based on seismic analysis for multiple locations (LHRN, LHRS, FWAY, NCTS, NCTN and REIN). Seismic Unit U3 contains faulted, folded, and truncated reflectors overlain by Seismic Unit U2b (onlap relationship, fanning reflectors adjacent to normal faults) and Seismic Unit U2a (minor amount of deformation with onlap relationship). Seismic Unit U1b comprises fanning reflectors (near folds or sediment sources) that onlap and downlap, recording uplift, subsidence, erosion, and volcanic input to the basin. Lastly, Seismic Unit U1a is drape sequence onto older units, and gravity flows within the axes of troughs.

Seismic Unit U3 is only sampled in the Waka Nui-1 well in northern Zealandia. Elsewhere, Seismic Unit U3 may be similar to the Murihiku Supergroup (Bache et al., 2014a; Bache et al., 2012a), or Triassic-Jurassic coal measures of the Clarence-Moreton Basin of Queensland (O'Brien et al., 1994, Ingram et al., 1996), or Late Jurassic and Early Cretaceous rift-related volcanoclastic Strzelecki Group of the Gippsland Basin (Norvick et al., 2001). Hence, Seismic Unit U3 may contain sandstone, mudstone, and organic-rich shale or coal, folded volcaniclastic sediment and magmatic rock formed on a low-lying broad continental margin that was episodically flooded by the ocean near a Mesozoic subduction margin (Bache et al., 2014a, Bache et al., 2012a, Mortimer, 2004). Seismic Unit U3 is mostly unsampled and it is plausible that organic-rich marine source rocks equivalent to those found in Timor-Leste and Papua New Guinea may also be present.

Seismic Unit U2b is interpreted as syn-rift (Bache et al., 2014a, Bache et al., 2012a, Herzer et al., 1999). Seismic Unit U2b is unsampled in the study area and restricted in extent. Comparison to New Zealand, New Caledonia and SE Australia suggest that Seismic Unit U2b may contain fluvial sandstone, mudstone and coal, grading upwards to shallow marine transgressive deposits (Campbell et al., 1985, Cluzel et al., 2012, Collot et al., 2009, King and Thrasher, 1996, Norvick et al., 2001). In the southern part of the region in Taranaki-Aotea Basin (NCTS, REIN), Seismic Unit U2b may correlate with mid Cretaceous coal measures, alluvial plain, and marginal marine facies (Uruski and Baillie, 2004, Collot et al., 2009, Strogen et al., 2017, King and Thrasher, 1996). Seismic 
Unit U2b may contain coaly source rocks as observed onshore New Caledonia ("Formation à charbons") and further south in NCTS (Herzer et al., 1999, Collot et al., 2009). Seismic Unit U2b in FWAY is interpreted as stacked delta fans from erosion of FWAY Ridge and LHR (Collot et al., 2009, Rouillard et al., 2015, Rouillard et al., 2017). Terrestrial and shallow marine sandstone in Seismic Unit U2b is possible reservoir rock.

Seismic Unit U2a is interpreted as transgressive marine sediments deposited during Zealandia thermal subsidence (Bache et al., 2014a). Seismic Unit U2a is Late Cretaceous to Eocene in age. Cretaceous carbonaceous mudstone (marine equivalent coaly mudstone) is known at Site U1509 (Sutherland, 2019b, Sutherland et al., 2018a) suggesting the base of the Seismic Unit U2a has potential for marine petroleum source rock in addition to the proven coaly source rocks of this age in Taranaki Basin (King and Thrasher, 1996). Transgressive sandstones within Seismic Unit U2a may contain reservoir rock similar to petroleum producing reservoirs of this age in Taranaki Basin.

Seismic Unit U1b resulted from regional uplift involving erosion that supplied clastic sediment into Seismic Unit U1b (Orr et al., 2020, Bache et al., 2014a). Based on seismic character, spatial distribution and information from available boreholes, Seismic Unit U1b contains mass-transport complexes and basin floor fans (Sutherland, 2019b). Basin floor fans could be reservoir rock. Eocene folding associated with Seismic Unit U1b generated structural traps in the southern part of the region.

Seismic Unit U1a is a drape sequence onto older units and contains gravity flows within the axes of troughs. Oligocene and Neogene chalk, calcareous ooze and marl represent overburden (Burns and Andrews, 1973, King and Thrasher, 1996, Sutherland, 2019b, Sutherland et al., 2018a, Bache et al., 2014a). 


\section{Cenozoic Sedimentation Rate}

\subsection{Introduction}

Maturation of Mesozoic source rocks was associated with Cenozoic burial. Migration and trapping of any petroleum might have been affected by tectonic tilting and faulting associated with initiation of the Tonga-Kermadec subduction system (see discussion in Chapter 2) (Bache et al., 2014b, Hashimoto et al., 2012, Rouillard et al., 2015, Sutherland et al., 2017). Accordingly, detailed estimates of Cenozoic sedimentation rates are crucial in reconstructing the burial histories of northern Zealandia and hence the timing and migration of petroleum migration in the context of trap development.

Northern Zealandia experienced significant tectonic modification during the Cenozoic that may have been associated with delamination of lithosphere and initiation of subduction followed by rapid foundering and rollback of the slab (Sutherland et al., 2010). New Caledonia Trough subsided, and Lord Howe Rise and Norfolk Ridge System experienced transient uplift (Sutherland et al., 2020). Late Cretaceous and Paleogene strata are affected by subtle tilting and local reverse faulting and folding. Thermal and dynamic processes accompanying lithosphere delamination appear to have generated broad $>700 \mathrm{~km}$ transient uplift with an amplitude of 1-2 km (Sutherland et al., 2010, Sutherland et al., 2020).

Climate played a key role in development of Cenozoic stratigraphic sequences over northern Zealandia, because most of the sediment is biogenic (Kennett, 1977, Kennett et al., 1975). The separation of Antarctica from Australia and the opening of the Tasmania Gateway caused regional changes in oceanic circulation during the Eocene to Oligocene (Kennett 1977). The Eocene-Oligocene boundary at $~ 34$ Ma signified the onset of significant Antarctica glaciation that reduced the temperature by $\sim 5^{\circ} \mathrm{C}$ and led to the formation of the Antarctic ice sheet (Kennett, 1977). The Antarctica Circumpolar Current (ACC) was initiated when the Tasmanian gateway opened in the early Oligocene (Carter et al., 2004, Kennett et al., 1975). A warmer sup-tropical gyre separated from the cold southern gyre affected distribution and migration of planktonic species (Kennett, 1980). Erosion in the deep ocean basins was due to an increase in bottom current activity. 
Environmental changes affected biogenic primary productivity and hence sedimentation rate.

The objective of this chapter is to describe the Cenozoic sedimentation rates succession deposited over northern Zealandia. This is achieved using boreholes to provide age and lithological calibration for seismic interpretations, and I restrict my analysis to regions near borehole control (Fig 1.2, 1.3, 1.4, 1.5 \& 1.6). Detailed age-models are tied to seismic reflection data (Sutherland et al., 2018a). I map and calculate Cenozoic depositional rates across northern Zealandia. Results are of interest for understanding past environmental variability and are needed to assess the timing of any potential hydrocarbon generation and expulsion (Henriksen et al., 2011, Sutherland et al., 2017, Sutherland et al., 2010).

Stratigraphic names used in this chapter are local to the immediate region being analysed, and most represent subdivisions of Zealandia Seismic Unit U1. I use local name definitions that are consistent with the approach of Bache et al. (2012) but note that these names are not consistent with Zealandia-wide megasequence nomenclature (Bache et al. 2014). The naming creates any inconvenience or confusion but following a previously used scheme seemed the most pragmatic way to proceed. It would be sensible in future to redefine all names to a uniform Zealandia-wide set of conventions.

\subsection{Mass accumulation rate (MAR)}

Mass accumulation rate (MAR) calculation is based on microfossil datums that define the age-depth relationship (Fig. 4.1) and hence the linear sedimentation rate at each site is converted to MAR using measurements of density and porosity (Sutherland, 2019a, Sutherland, 2019b, Sutherland et al., 2018a). Age models are available from recent paleontological reanalysis (Sutherland, per. comm. 2019) for each site (U1506-U1510 and U208, U207 and U592). 


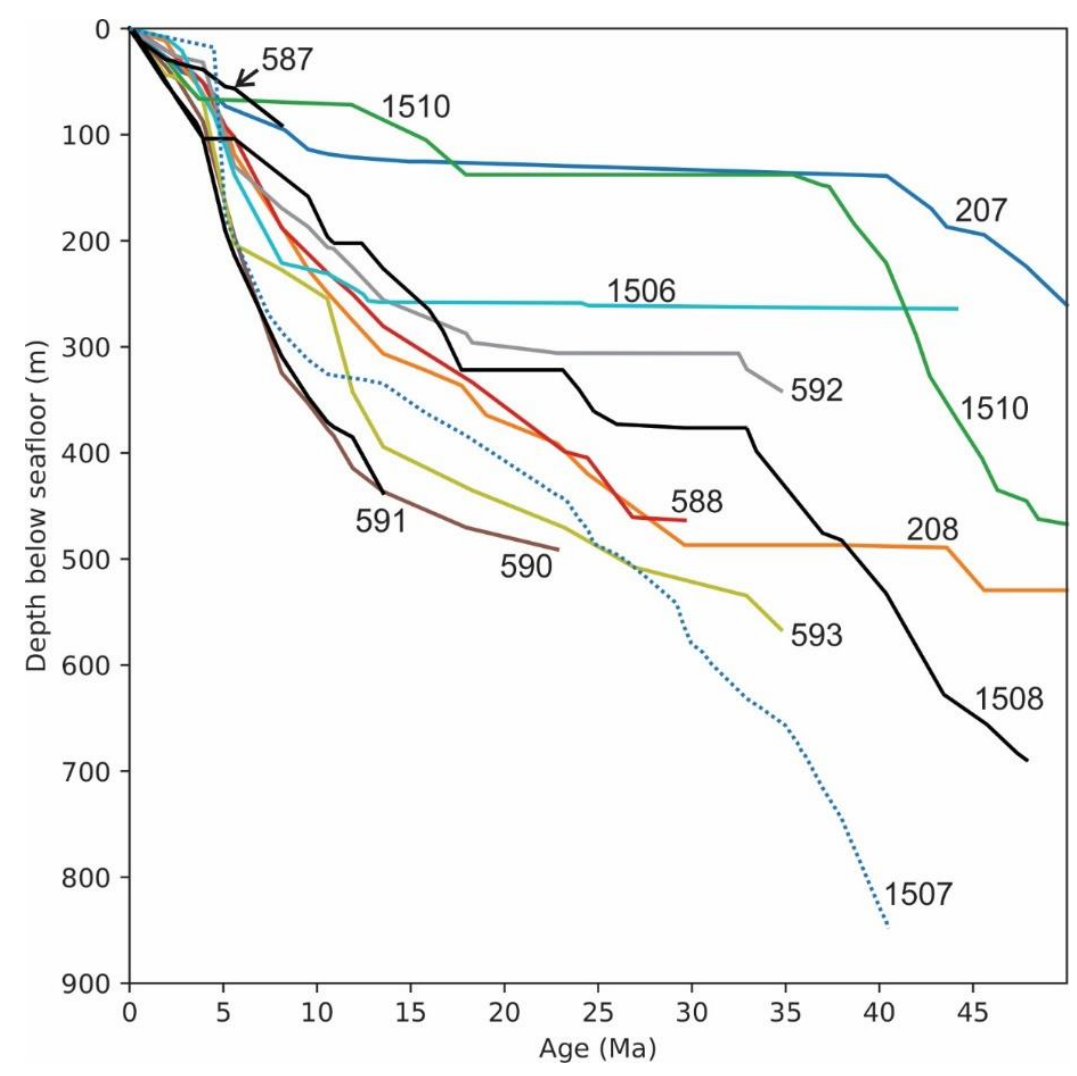

Figure 4.1 Depth age relationships at IODP boreholes and DSDP Sites (Burns, 1973a, Burns and Andrews, 1973; Sutherland, pers. comm. 2019; Sutherland, 2019c; Sutherland et al., 2018b).

The linear sedimentation rate (LSR) is simply the observed thickness of a sediment layer divided by period of time it took to deposit. MAR is calculated using depth-density and depth-porosity relationships. The relation between depth of burial and the density and porosity for different types of sediment can be expressed by exponential equations (Athy, 1930).

$$
\begin{gathered}
\phi(z)=\phi_{o} e^{-\frac{z}{L}} \\
\rho_{\text {sed }}=\rho_{\text {fluid }} \phi+\rho_{\text {grain }}(1-\phi) \\
\text { Grain mass }=(1-\phi) \rho
\end{gathered}
$$

Where $z$ is depth below the surface, L represents compaction length; $\rho$ is grain density and $\phi$ is porosity. 
MAR is calculated for each borehole, and for layers defined by seismic horizons that could be tied to boreholes. Rupert Sutherland wrote computer code that made these calculations. We use surface porosity and compaction length parameters from recent measurements and compilations (Stratford et al., 2018, Sutherland R. et al., 2019) (Fig. 4.2).
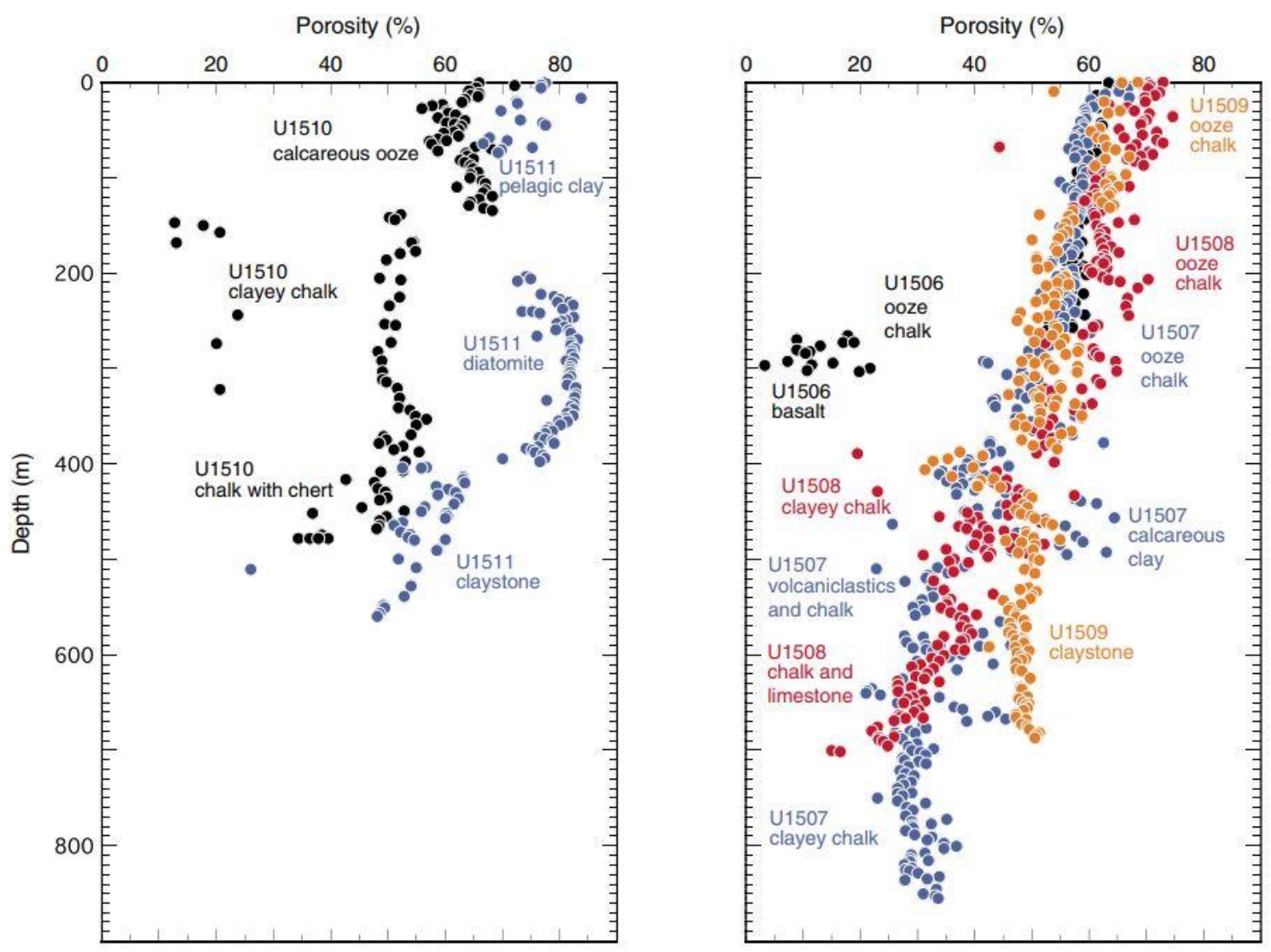

Figure 4.2. IODP Expedition 371 porosity measurements of bathyal pelagic sediment (Sutherland, 2019a, Sutherland, 2019b, Sutherland et al., 2018a). The porosity-depth profiles have near surface porosity of 60 to $70 \%$ and a decrease to about 25 to $30 \%$ by $700 \mathrm{~m}$ depth below seabed. 


\subsection{Northern Lord Howe Rise (LHRN)}

As many reflectors as possible above the Eocene-Oligocene unconformity were locally mapped between boreholes DSDP 208 and IODP U1506 (Fig. 1.2 \& 2.4). The Oligocene-Eocene unconformity creates a distinctive negative-polarity seismic reflector that is underlain by several high amplitude continuous reflectors (Stratford et al., 2018). Five seismic units (U5-U9) and thirteen sub-units were identified (Fig. 4.3, 4.4, 4.5 \& 4.6). These are all subunits of the regional Zealandia U1 megasequence.

Some reflectors can be mapped regionally between boreholes, whereas others can only be confidently identified close to one of the boreholes (Fig. $4.6 \& 4.7$ ). The extent to which a unit can be mapped is identified in its name: LHRN-for regional extent within the 302 survey, and U208- or U1506- for local extent.

\subsubsection{Results of seismic stratigraphy interpretation}

The following section describes the seismic stratigraphy at Site U208 and U1506 using seismic surveys 302 and TAN1409-LHRN. Site U208 has four bounding surfaces (UB-LHRN-5 to UB-LHRN-8) defining four seismic units that are further subdivided into ten sub-units (Fig. $4.3 \& 4.4$ ). 


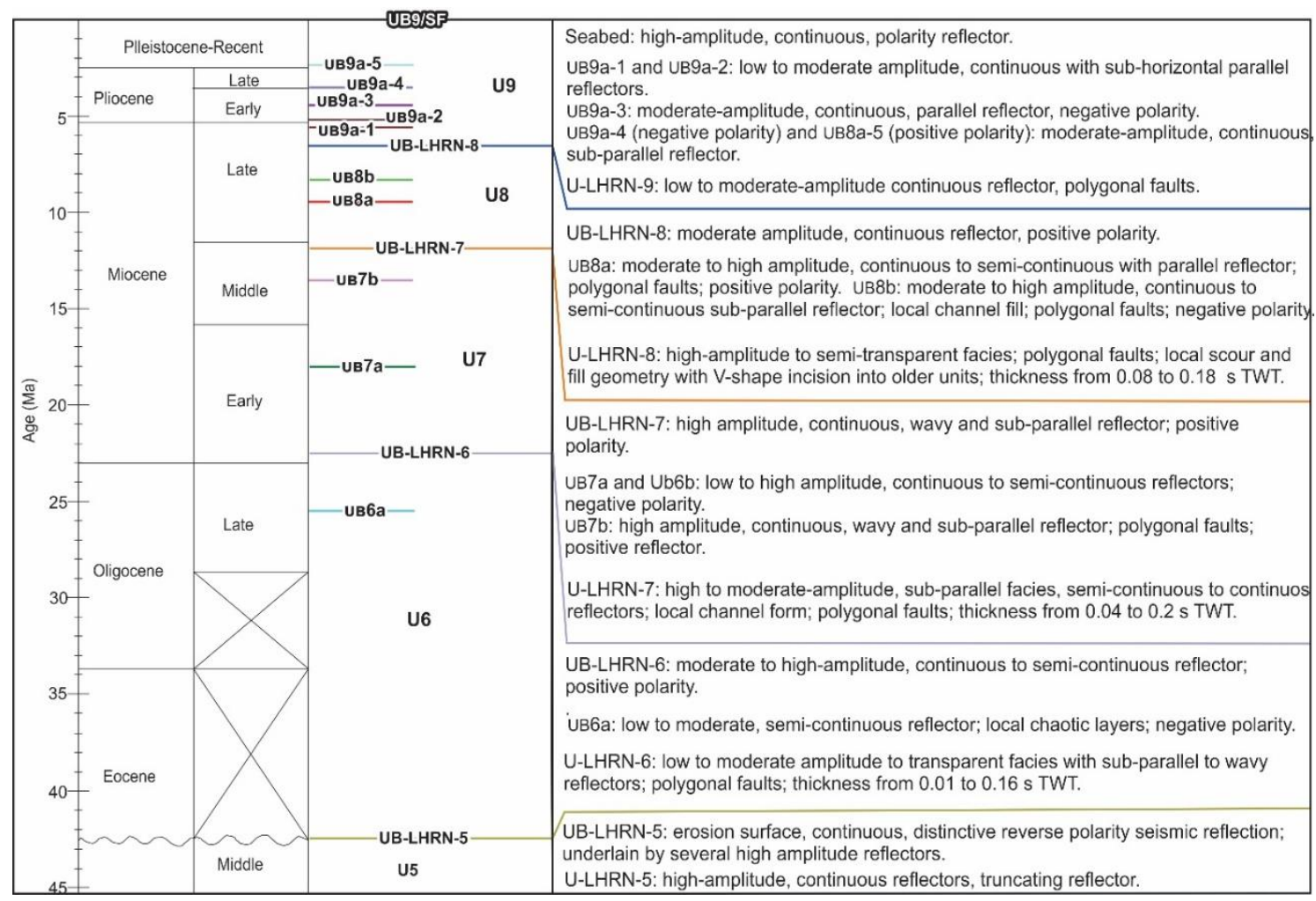

Figure 4.3. Seismic stratigraphy of northern of Lord Howe Rise near Site U208.

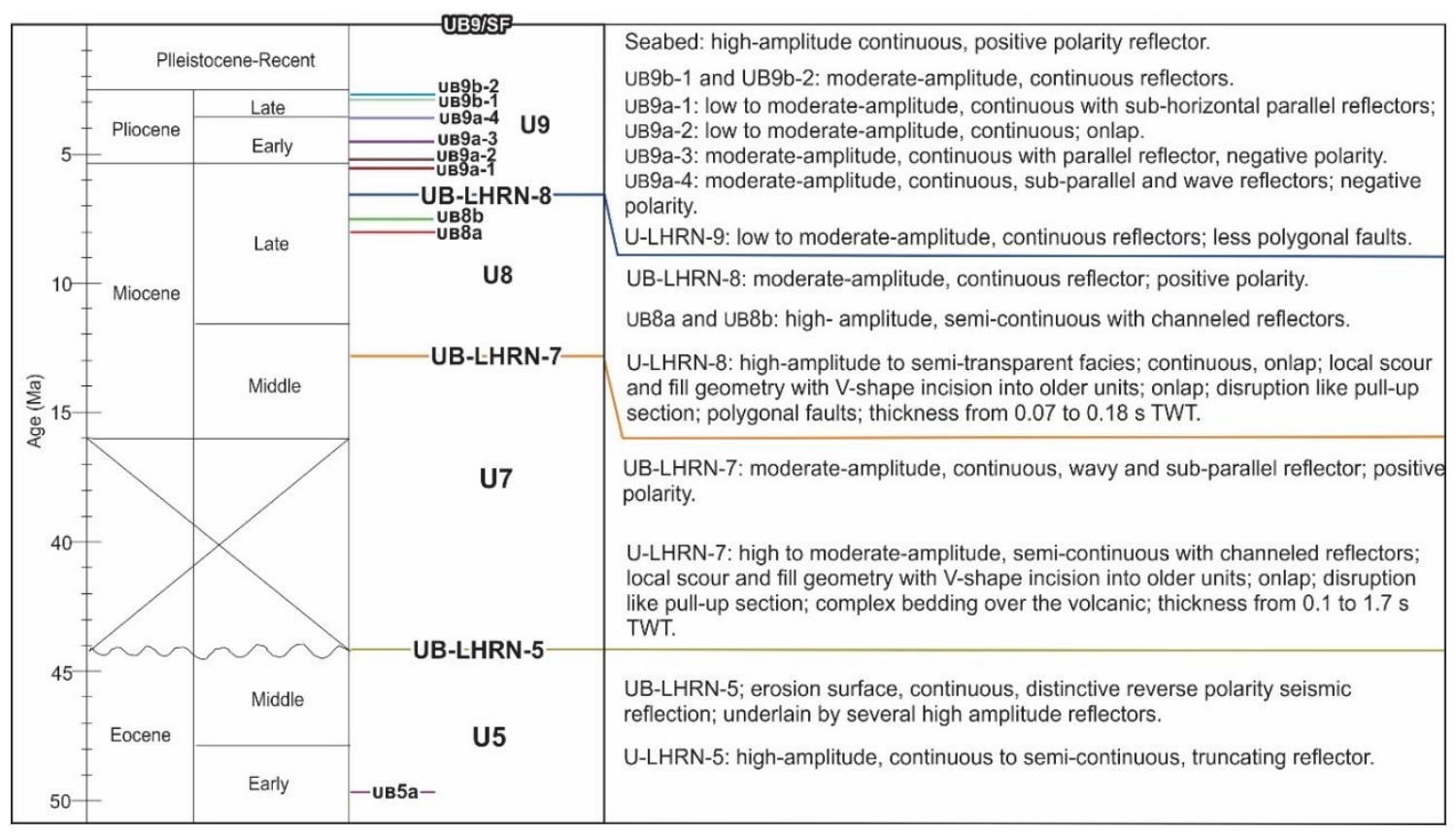

Figure 4.4. Seismic stratigraphy of northern Lord Howe Rise near Site U1506. 


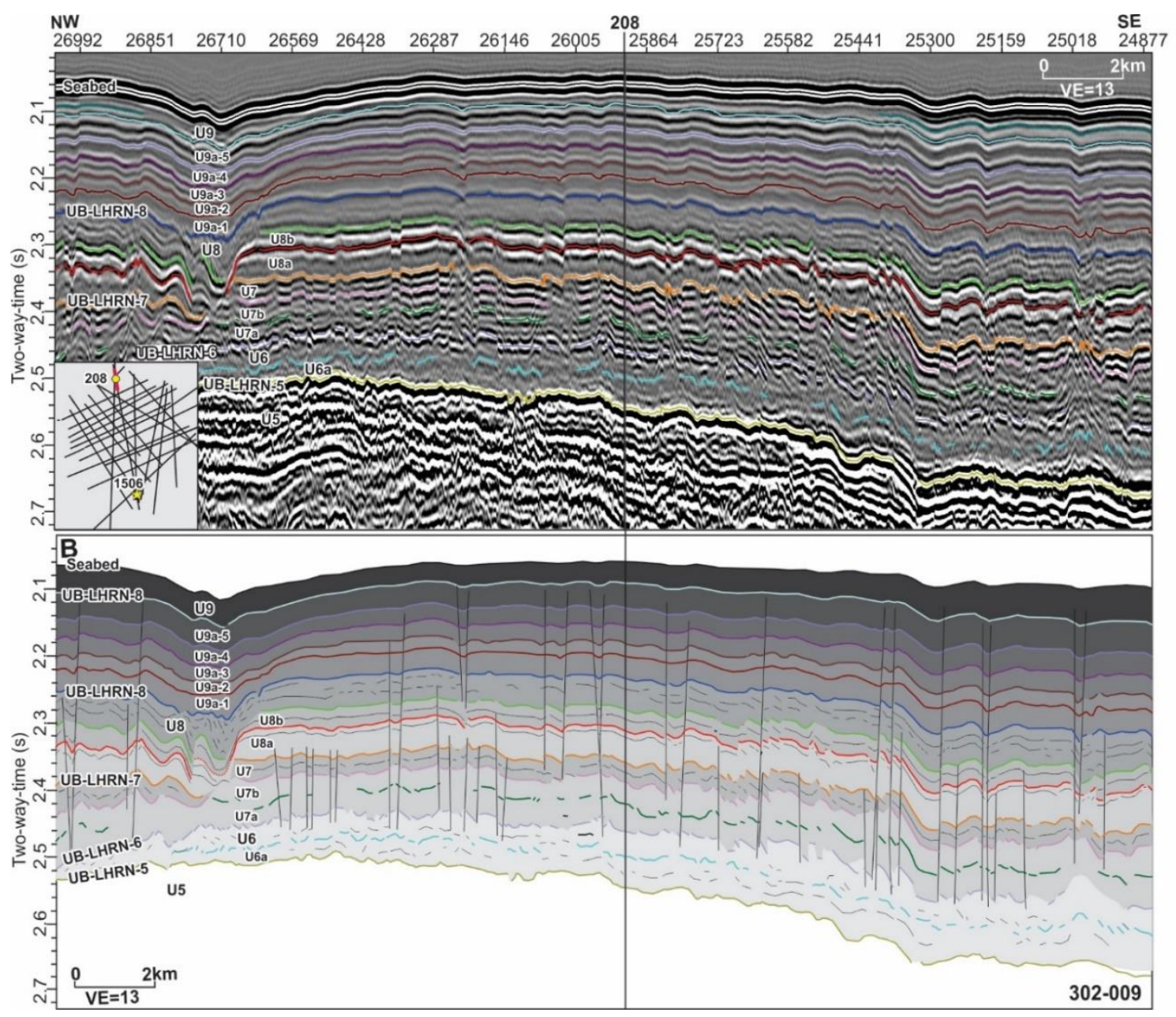

Figure 4.5. Seismic line 302-009 on the northern Lord Howe Rise at Site U208, (A) seismic reflection showing seismic time horizons interpretation in colour (B) polygonal faulting in Neogene sediments. 


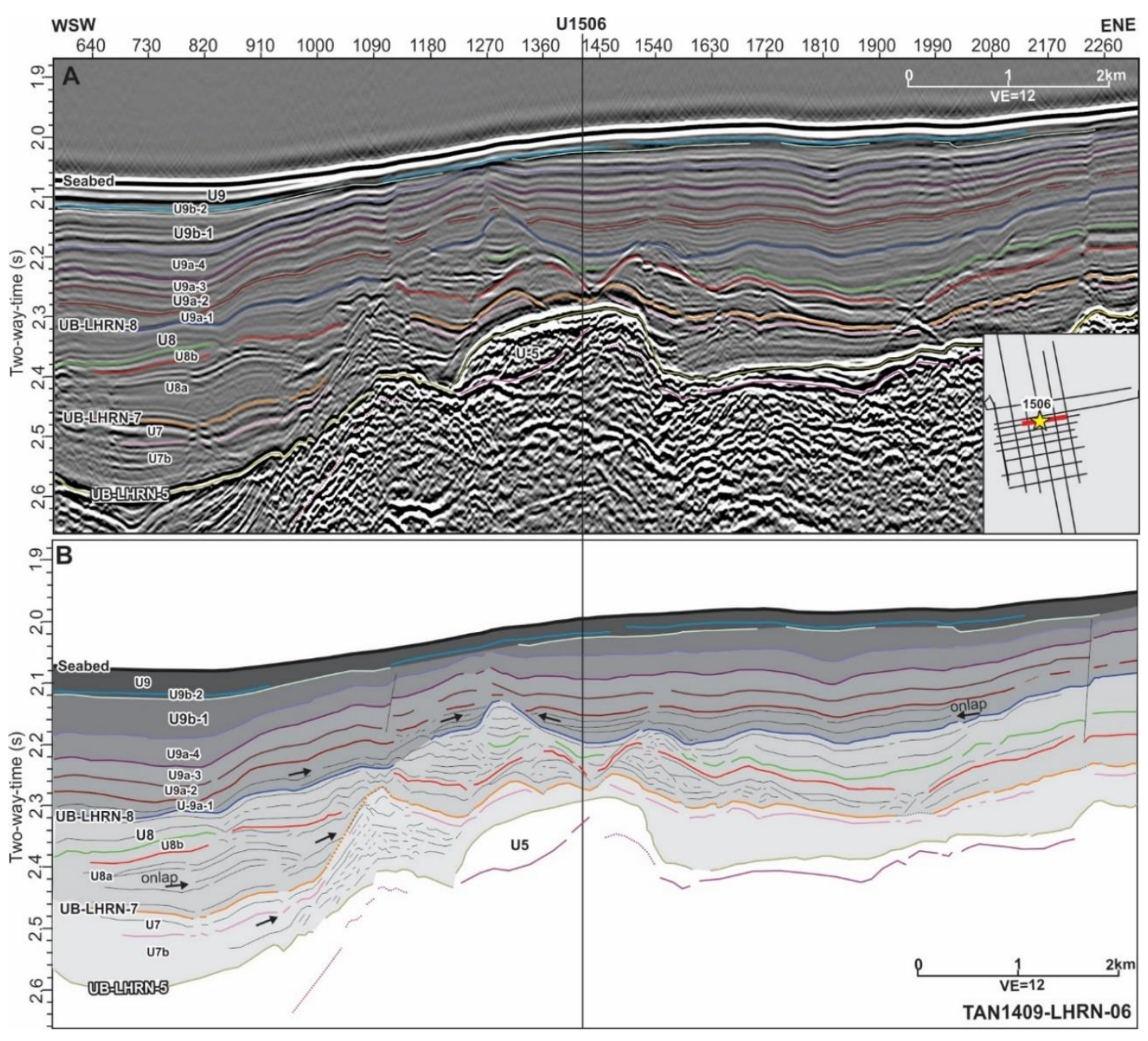

Figure 4.6. Seismic reflection line TAN1409-LHRN-06 through borehole U1506, (A) seismic reflection image, and (B) sketch of scour and onlapping reflector geometries. Miocene/Eocene unconformity appears as a continuous reverse polarity reflection nearby, but is a positive reflection at SiteU1506.

Seismic Unit 6 (U-LHRN-6) represents a transparent seismic facies with low to moderate-amplitude semi-continuous reflectors of Late Oligocene age. There is an unconformity/hiatus documented at Site U208 between U-LHRN-6 and ULHRN-5 (Fig. 4.5). This unit is composed of foraminiferal nannofossil chalk with clay (Fig. 4.7). ULHRN-6 strata onlap volcanic edifices associated with the Eocene-Oligocene unconformity elsewhere in the region (Higgins et al., 2015, Sutherland et al., 2017). 


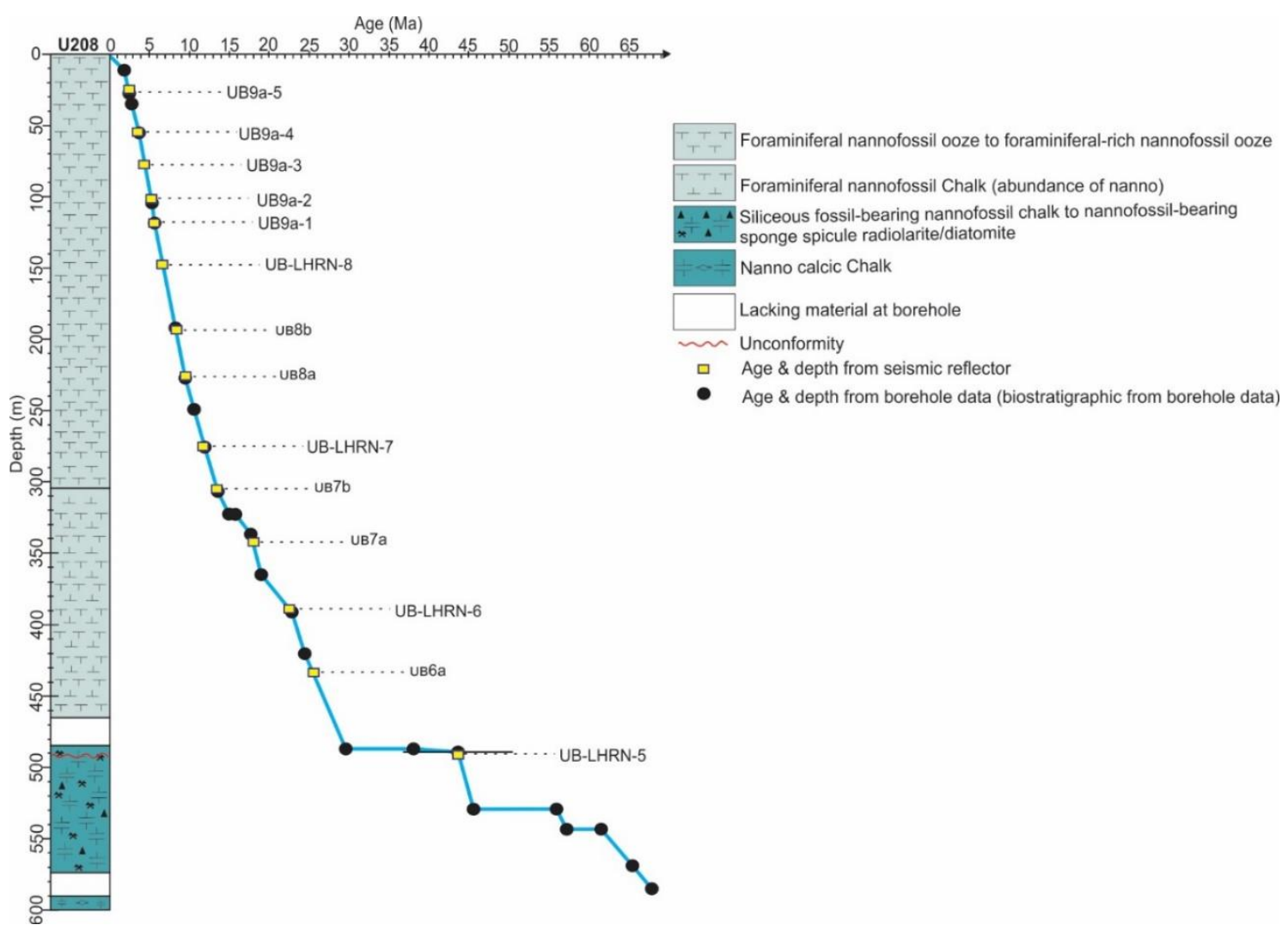

Figure 4.7. Borehole DSDP 208 age-depth relationship. The TWT seismic reflectors were converted to depth using velocity model (Sutherland et al., pers. comm. 2019). Late Oligocene/Middle Eocene unconformity UB-LHRN-5 occurs at depth $492.4 \mathrm{~m}$.

Onlaps and scour development near Site U1506 suggest strong bottom-current activity (Fig. 2.4) that likely caused erosion of U-LHRN-6 at Site U1506. The channelling and erosion surfaces indicate periods of strong bottom currents.

The Miocene to Pliocene succession correlates with Seismic Units 7, 8 and 9 (ULHRN-7, U-LHRN-8 and U-LHRN-9). Based on foraminiferal data and age model, these units were deposited between 22.5 and 5.6 Ma and are composed of calcareous ooze and chalk (Fig. $4.7 \& 4.8$ ). There are small faults in the chalk and ooze layers that are interpreted as polygonal faults (Fig. 4.5). Polygonal faults are observed most places near Site U208 (Fig. 4.5) but are not so common at Site U1506 (Fig. 4.6). At Site U1506, all units are affected by polygonal faulting but at Site U208, polygonal faults die out towards the seabed, and they only develop as part of the response to compaction and ooze-chalk transition. Polygonal faulting reflects dewatering of sediment during compaction. ULHRN-7 and U-LHRN-8 are characterised by wide V shape channels with bidirectional onlap (Fig. 4.6) near Site U1506, where V-shape erosional features may be indicative of channelized bottom currents. 
UB-LHRN-5 represents a hiatus from middle Eocene to Oligocene (25.5 Ma to 43.7 Ma) (Fig. 4.3 \& 4.4). At Site 208, there is an unconformity between Seismic Units 5 and 6. A major reorganisation of ocean currents is inferred from changes in foraminifera assemblages in the Oligocene (foraminiferal and nannofossil chalk) and middle Eocene (siliceous microfossil-bearing chalk, radiolarite, and diatomite) (Burns and Andrews, 1973, Kennett et al., 1975). This unconformity is also documented at borehole IODP U1506 between U-LHRN-7 and U-LHRN-5 (Fig. 4.4). Burrow fill sampled in subunit 1c of Sutherland et al. (2018) is late Oligocene in age and indicates erosion or nondeposition of middle Eocene to upper Oligocene sediment (Fig 4.3, $4.4 \&$ 4.6). This unconformity could have a primary tectonic origin but be enhanced in place by non-deposition due to current action.

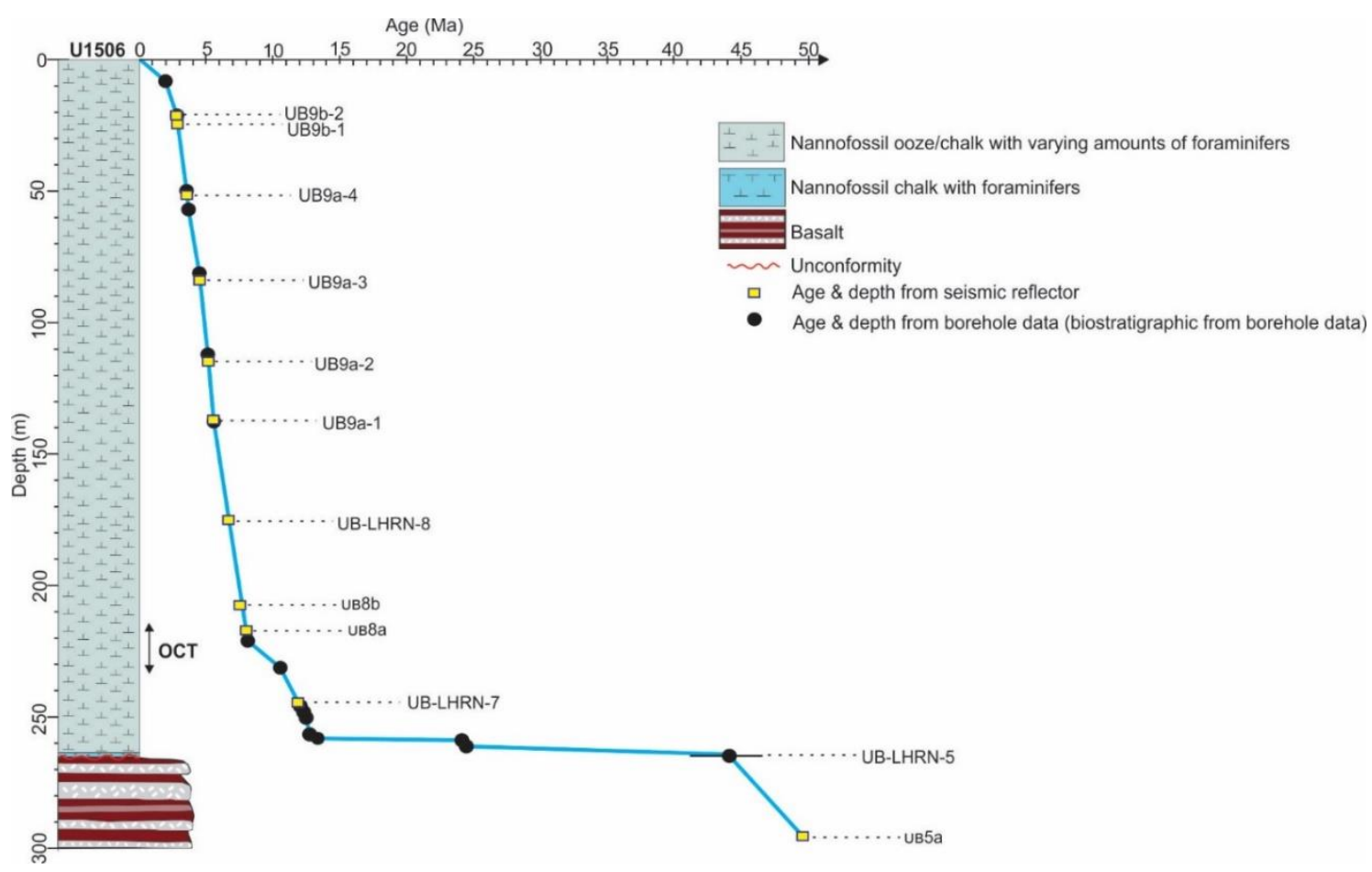

Figure 4.8. Borehole IODP U1506 age-depth relationship. The TWT seismic reflectors were converted to depth using velocity model (Sutherland et al., pers. comm. 2019). 


\subsubsection{Burial analysis}

The mass accumulation rate (MAR) was calculated using seismic reflectors and well data (microfossil datums). A solid red line represents the average MAR (Fig. 4.9). Figure 4.9 includes values for the rates of mass accumulation for sediment that was based on microfossil datums from boreholes (U1506, U208, U588, U589, U590 and U591) and extrapolated and averaged away from the borehole using seismic mapping (U1506 and U208). The early Eocene ( 50 Ma) has MAR about $8 \mathrm{~kg} \mathrm{ky}^{-1} \mathrm{~m}^{-2}$ and increased to $27 \mathrm{~kg}$ $\mathrm{ky}^{-1} \mathrm{~m}^{-2}$ in middle Eocene ( $45 \mathrm{Ma}$ ). The middle Eocene ( $\left.43 \mathrm{Ma}\right)$ to early Oligocene ( $30 \mathrm{Ma}$ ) have constant MAR of about 1 to $2 \mathrm{~kg} \mathrm{ky}^{-1} \mathrm{~m}^{-2}$. The MAR value slightly increased from 5 to $15 \mathrm{~kg} \mathrm{ky}^{-1} \mathrm{~m}^{-2}$ in the Late Oligocene ( $25 \mathrm{Ma}$ ), which began to fluctuate about 23 to $11 \mathrm{Ma}$ ago (early to late Miocene). During the late Miocene to early Pliocene $~ 8-3 \mathrm{Ma}$, there were high accumulation rates that reached a peak of about 50 to $59 \mathrm{~kg} \mathrm{ky}^{-1} \mathrm{~m}^{-2}$. The accumulation rates during the late Pliocene to Pleistocene fell from 59 to $10 \mathrm{~kg} \mathrm{ky}^{-1} \mathrm{~m}^{-2}$. There is consistently higher accumulation rate through late Miocene to early Pliocene time.

Changes in MAR may reflect actual changes in calcareous biogenic productivity related to global climate events (Kennett and von der Borch, 1986). The regional climate may cause changes in ocean circulation (Fig. 2.2). The region LHRN is located in the central zone of the Tasman Front, which is the oceanic current that flows past northern New Zealand (Fig. $2.2 \&$ 2.4). The highest MAR during latest Miocene may reflect increased biogenic productivity due to nutrient-enriched water near divergences in ocean current.

The lower MAR value during the latest Pliocene and Quaternary are probably related to increased winnowing by bottom currents varying the amount of foraminifera in this interval at Sites U1506 and U590 may indicate that sediments experienced a period of fluctuating bottom current activity (Kennett and von der Borch, 1986). Foraminifera documented at Site U208 have faunal changes in the Pleistocene. 


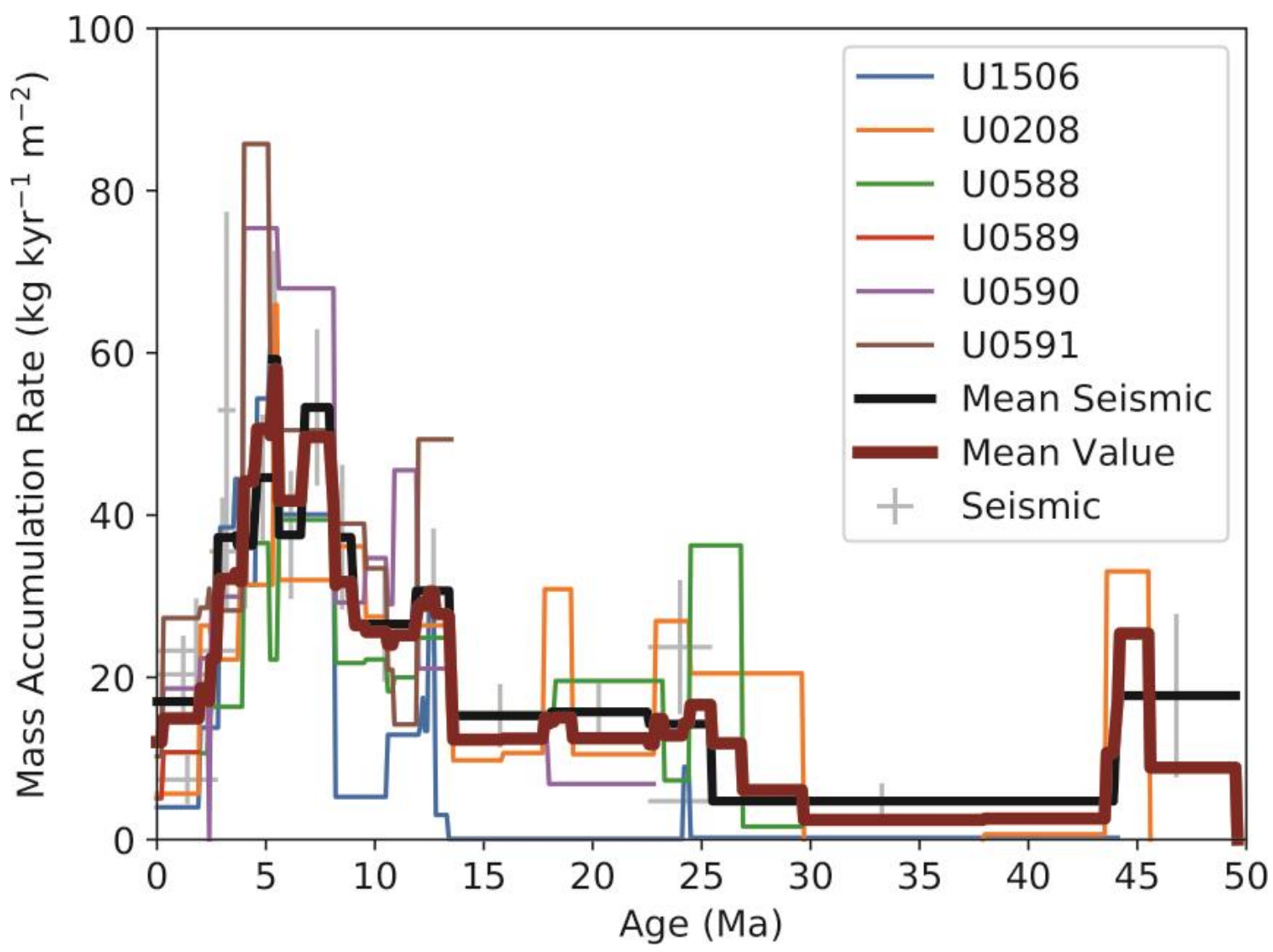

Figure 4.9. Line graph shows mass accumulation rate over time for the boreholes and seismic reflectors on northern Lord Howe Rise. Grey crosses are mass accumulation rate from seismic units (horizontal = age range of the unit for the top and the bottom $\&$ vertical = standard deviation of the mass accumulation rate actual lateral variability). The solid black line is the mean value of seismic reflector data. The solid red line is the average of seismic and well data. 


\subsection{Southern Lord Howe Rise (LHRS)}

The southern Lord Howe Rise (LHRS) region was interpreted over about 10,000 km² with age and sediment calibration provided by three Sites U1510, U207 and U592 (Fig. $1.1 \&$ Fig. 1.2). These three sites are located near the southern end of the LHRS.

Seismic mapping was tied to Sites U1510, U207 and U592. Each bounding reflector was picked based on its relationship to termination of overlying and underlying reflectors (Mitchum Jr et al., 1977a, Mitchum Jr et al., 1977b, Vail et al., 1977). Several key stratigraphic surfaces (seismic unconformity), seismic units and sub-units were defined (Fig. $4.10 \& 4.11$ ).

It is hard to determine the stratigraphic relationship between these three boreholes due to a lack of continuity of the succession across the LHRS region. This is partly related to local tectonism and associated volcanism that resulted in development of unconformities (Sutherland et al., 2017, Sutherland et al., 2010). There is clear evidence of this in seismic lines TAN1409-LHRS-02 (Fig. 4.11 \& 4.12) and TAN1409-LHRS-01 (Fig. 4.17).

\subsubsection{Seismic interpretation for borehole IODP U1510}

Two unconformities (UB-U1510-8 and UB-U1510-6) were identified at Site U1510 bounding four seismic sub-units (Fig. 4.11). Four seismic sub-units are part of the Zealandia-U1 megasequence. 


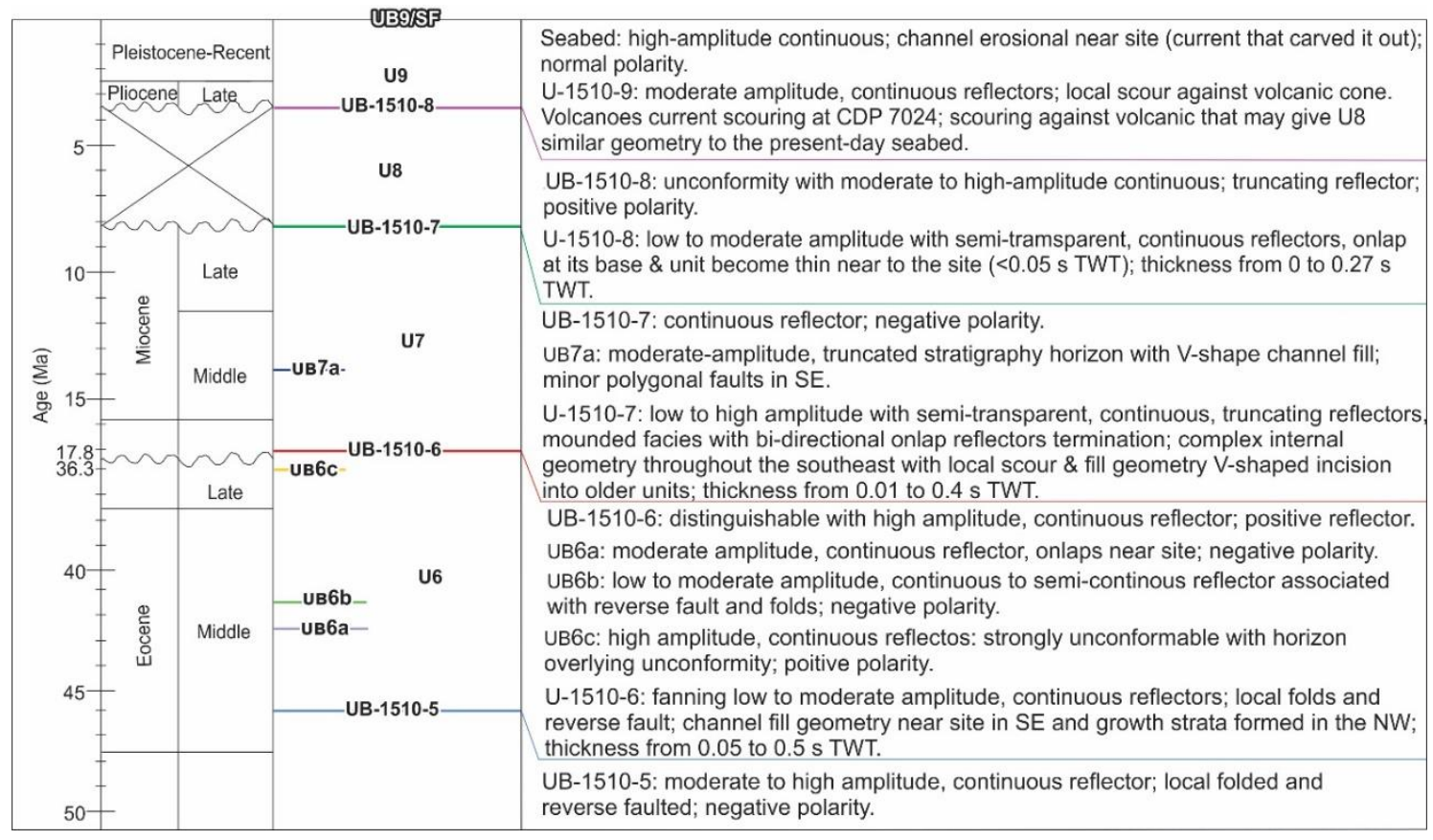

Figure 4.10. Seismic stratigraphy for Lord Howe Rise near Site U1510.

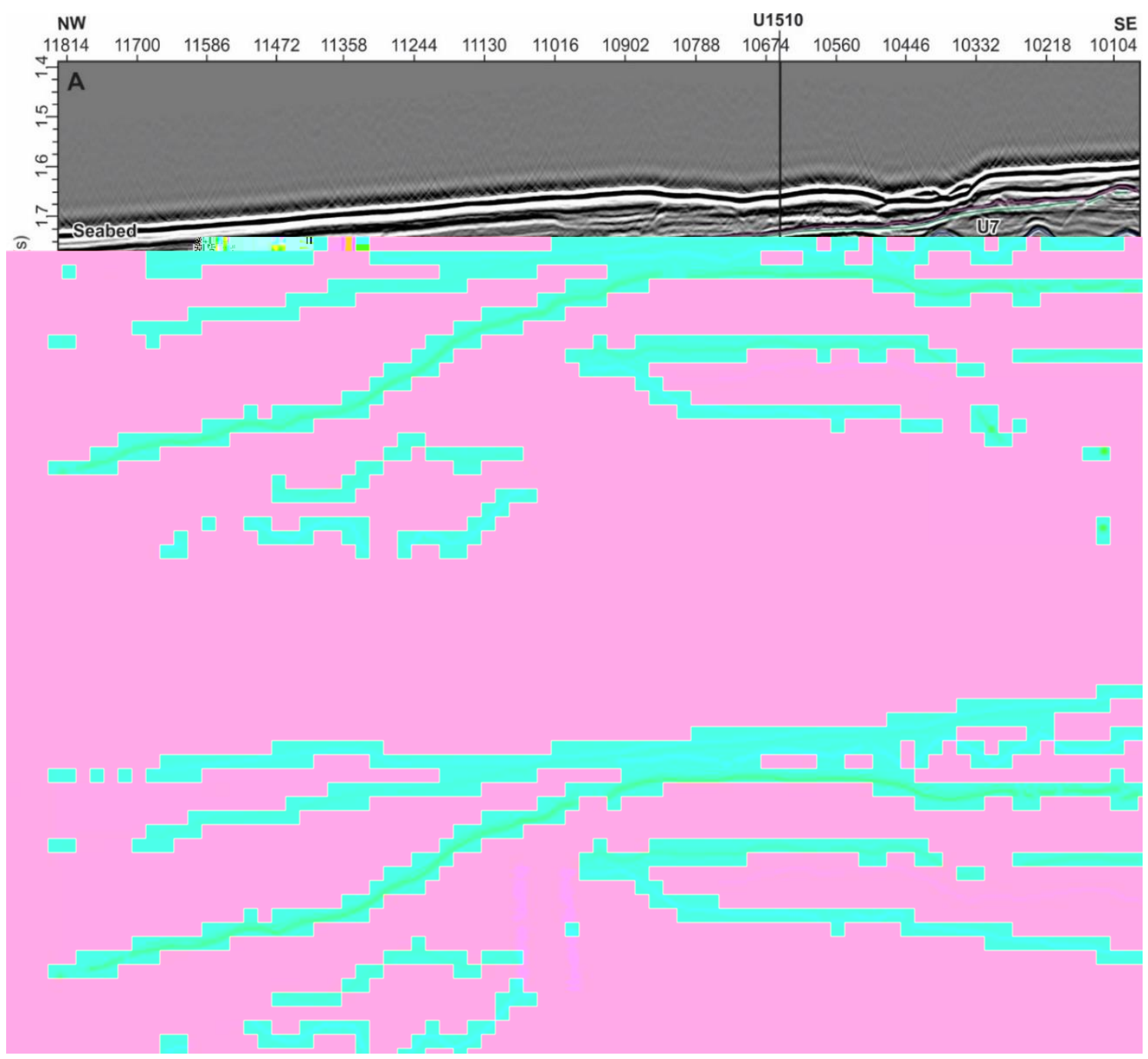

Figure 4.11. Seismic reflection line TAN1409-LHRS-02 at Site U1510, (A) seismic reflection image, and (B) sketch of onlapping sediments, which extended to the NW and sediments appear to compress in the SE. 
Seismic Unit 6 (U-1510-6) spans the Eocene 46 to 36.3 Ma (Fig. 4.10). U-1510-6 comprises clayey calcareous chalk with bioclasts punctuated by cherty limestone and chert (Fig. 4.13). Folds within U-1510-6 are associated with reverse faults that lie beneath sub-unit U6a (Fig. 11). This reverse faulting and associated uplift during the Eocene is referred to as the Tectonic Event of the Cenozoic in the Tasman Area (TECTA) (Sutherland et al., 2017). U-1510-6 strata may record two types of deformation including a folded and faulted succession pre-dating deformation overlain by an onlapping syntectonic sequence. U-1510-6 contains onlapping (UB-1510-6a) and growth strata reflectors that indicate progressive deformation (Fig. 4.11).

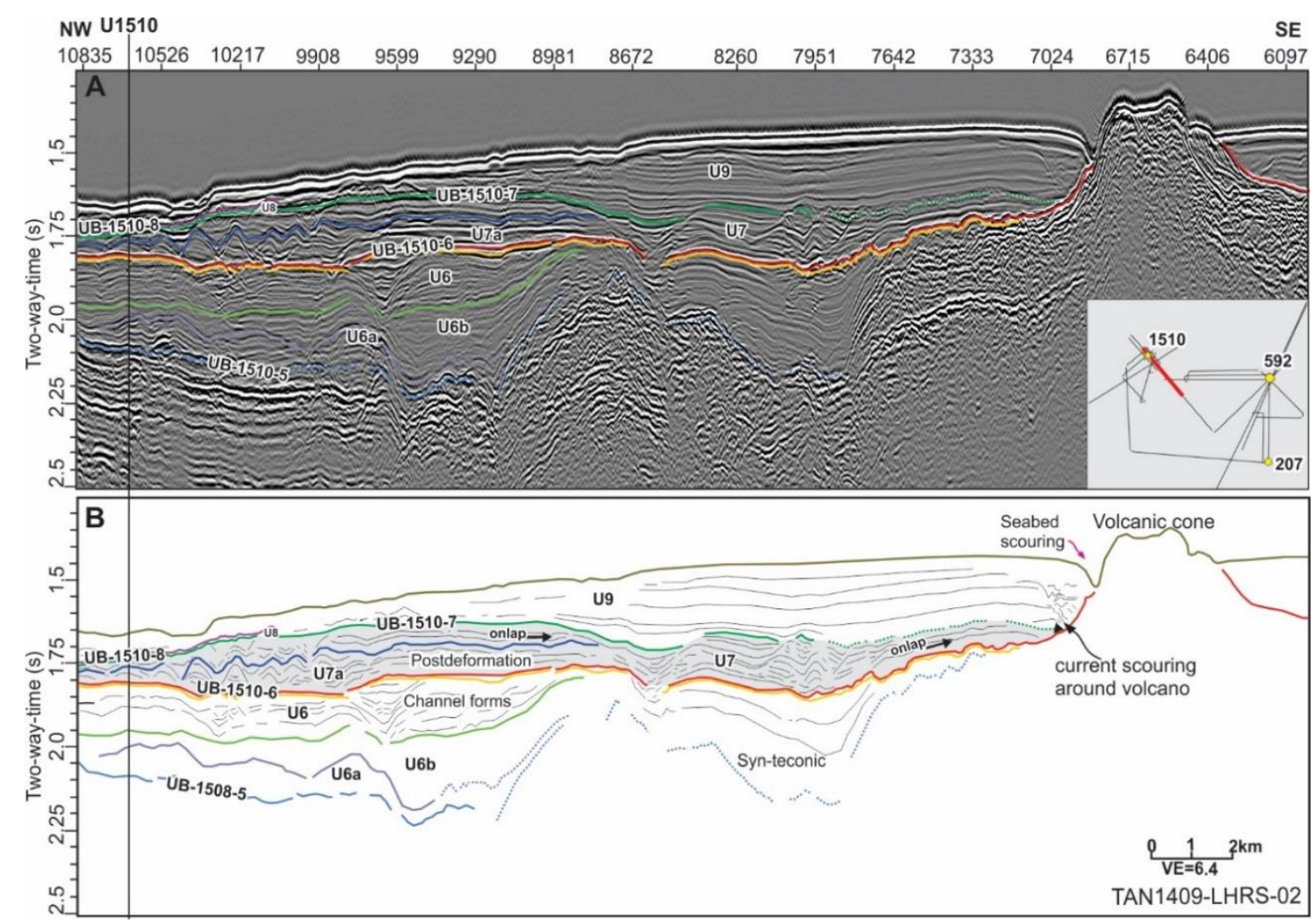

Figure 4.12. Seismic reflection line TAN1409-LHRS-02 through borehole U1510, (A) seismic reflection image, and (B) illustrates Eocene reverse faulting, deformation, volcanism and erosional unconformity.

The Miocene to Pleistocene 17.8 to 3.6 Ma succession correlates with Seismic Units 7, 8 and 9 (U-1510-7, U-1510-8 and U-1510-9) (Fig. 4.10 \& 4.11). U-1510-7 is composed of homogeneous calcareous ooze alternating with discrete beds of foraminiferal ooze (Fig. 4.13). U-1510-7 contain unconformities interpreted as current scours and channel complexes, and strata onlap small folds and volcanic edifices in the southeast of LHRS 
(Fig. 4.12). U-1510-8 and U-1510-9 are made up of calcareous ooze alternating with foraminiferal ooze (Fig. 4.13).

A late Eocene-early Miocene unconformity (UB6), represented by a high amplitude continuous reflector and onlapped by U7 strata (Fig. $4.11 \& 4.12$ ), exists between U6 and U7 with missing time spanning 36.3 to 17.8 Ma. A late Miocene-early Pliocene unconformity (UB8) exits between U8 and U9 (3.6 Ma) (Fig. 4.10).

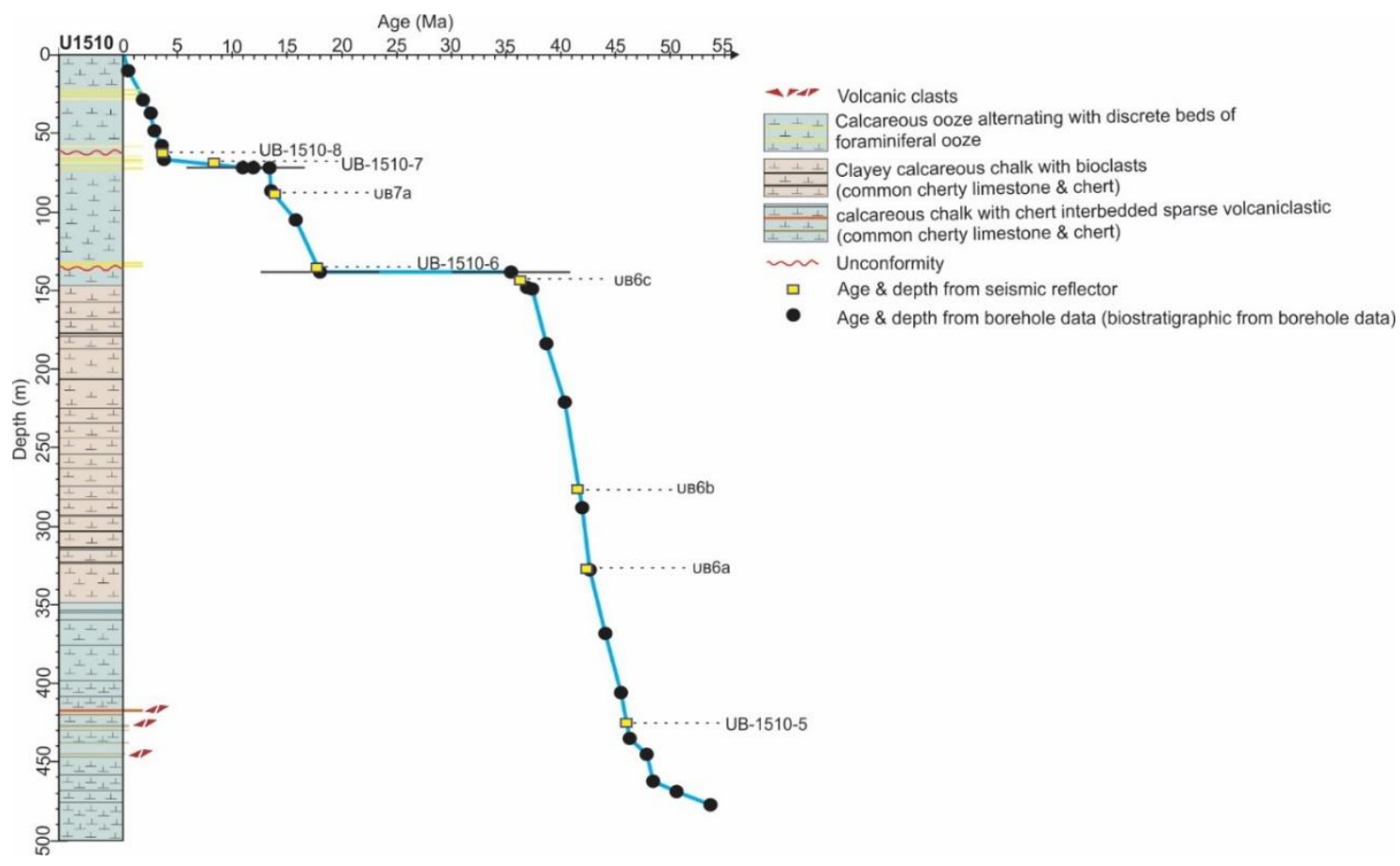

Figure 4.13. IODP U1510 age-depth relationship. Stratigraphy column shows lithology and is correlated biostratigraphic data and TWT seismic reflectors. (Sutherland, 2019a, Sutherland, 2019b). TWT seismic reflectors were converted to depth using velocity model (Sutherland et al., pers. Comm. 2019). 


\subsubsection{Seismic interpretation for boreholes DSDP 207 and 592}

Sites U207 and U592 have two unconformities (UB-207-4 and UB-592-5) and six seismic units that are subdivided into ten seismic sub-units (Fig. 4.14, $4.15 \& 4.16$ ).

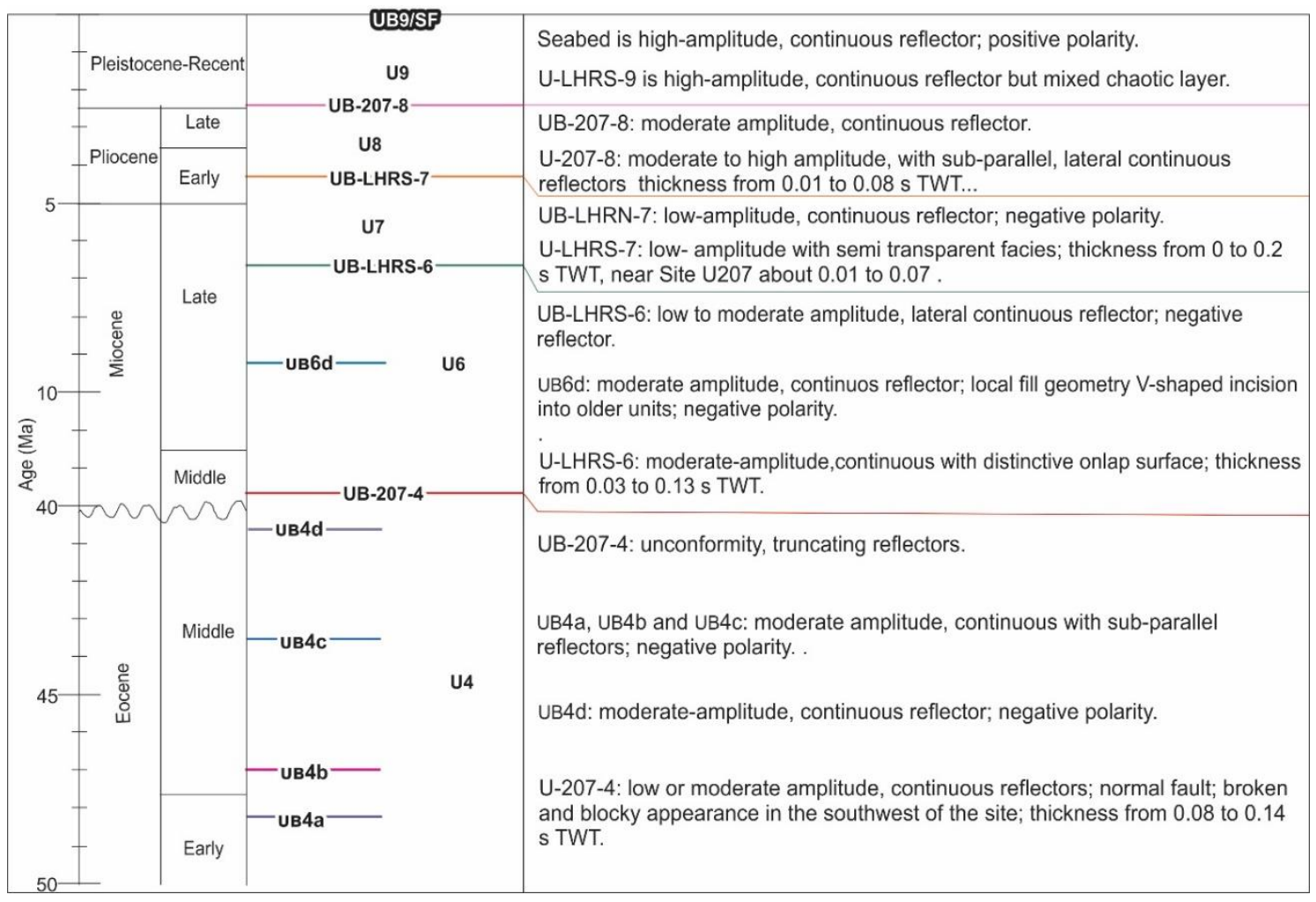

Figure 4.14. Seismic stratigraphy for Lord Howe Rise near Site U207. 


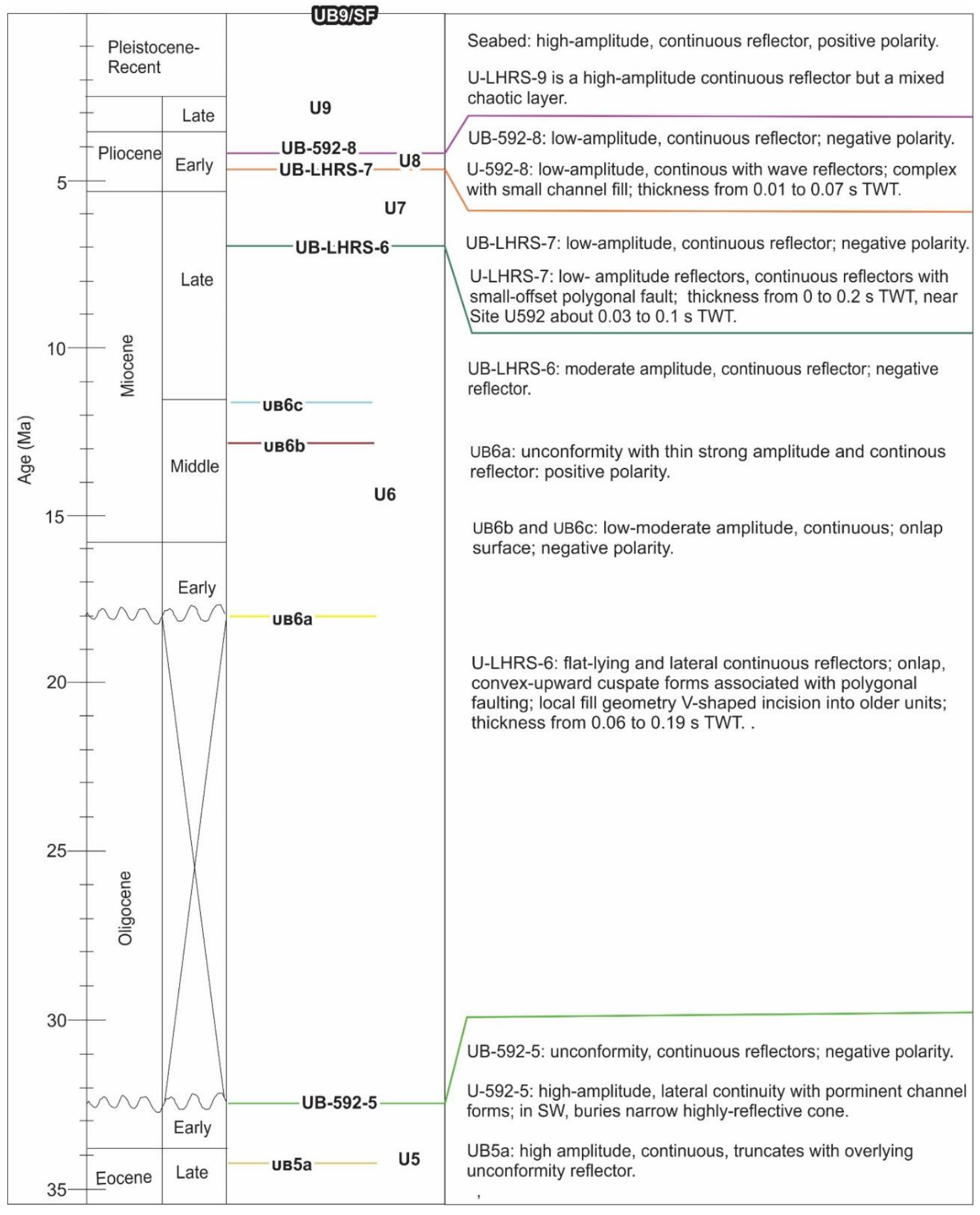

Figure 4.15. Seismic stratigraphy for Lord Howe Rise near Site U592. 


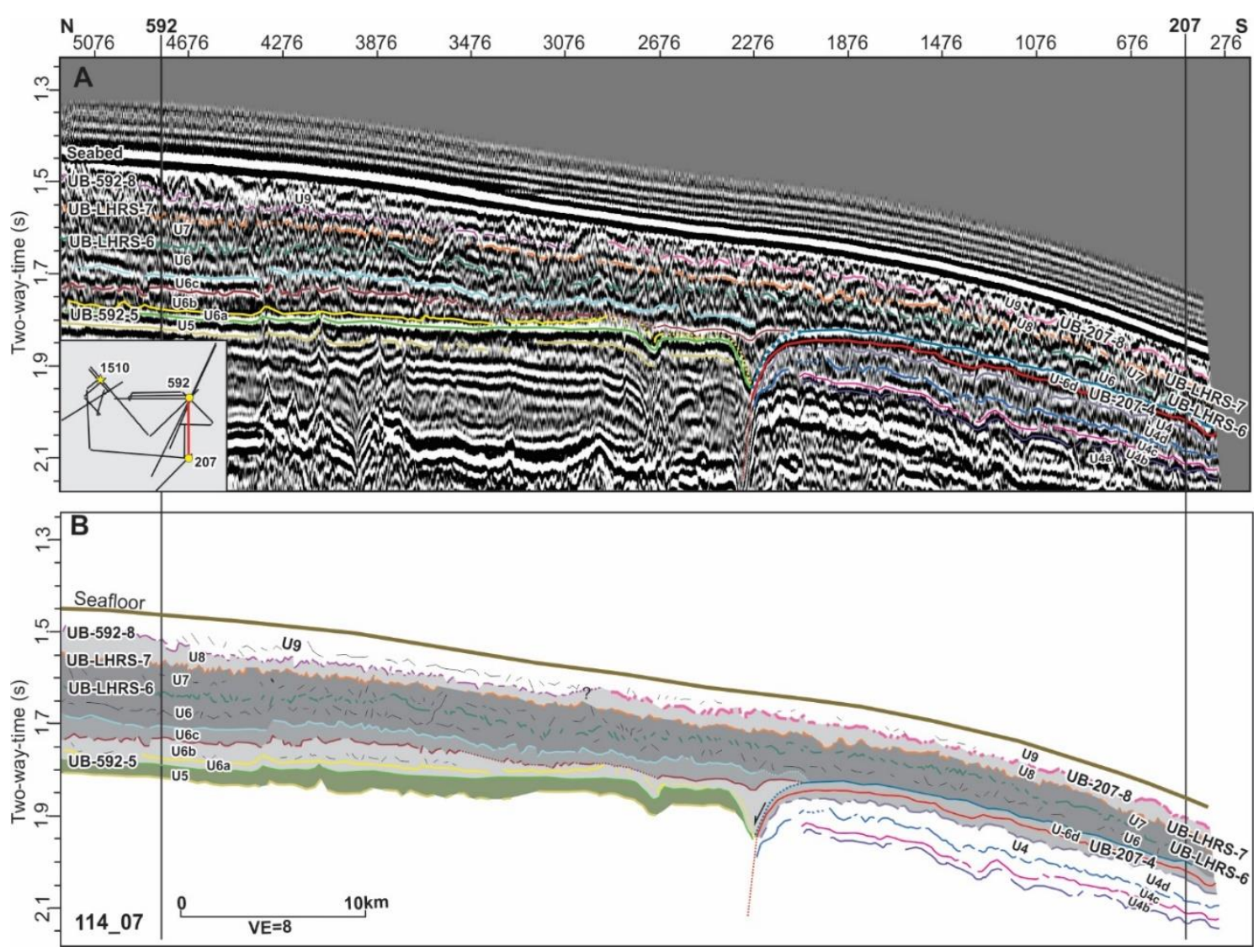

Figure 4.16. Seismic reflection line 114_07 at Site U592 and U207. (A) seismic reflection image, and (B) two sites show a lack of continuity of strata beneath an unconformity.

Seismic Units 4 and 5 (U-207-4 \& U-5925) are locally folded and have fanning reflectors. U-207-4 at Site U207 has age 48 to 40.6 Ma (Fig 4.14 \& 4.15). U-207-4 comprises calcareous fossil ooze with clay (Fig. 4.18). U-592-5 at Site U592 has age 34.3 to 32.5 and is made up of calcareous fossil ooze (Fig. 4.19). The channeling and erosion within U-207-4 and U-592-5 suggest significant downslope movement (Fig. 4.16). The volcanic activity was characterised by small cones associated with U-592-5.

The Miocene to Pleistocene succession correlates with Seismic Units 6, 7, 8 and 9 (U-LHRS-6, U-LHRS-7, U-LHRS-8 and U-LHRS-9) that have age range from 18 to 0 Ma (Fig. $4.14 \& 4.15$ ). These units are calcareous fossil ooze (Fig. $4.18 \& 4.19$ ) that was deposited in a bathyal environment (Kennett and von der Borch, 1986). Polygonal faulting affects these units. Flat unconformity formed between UB-207-4 and UB-592-5, with a possible relationship to past sea level (Sutherland et al., 2010). 

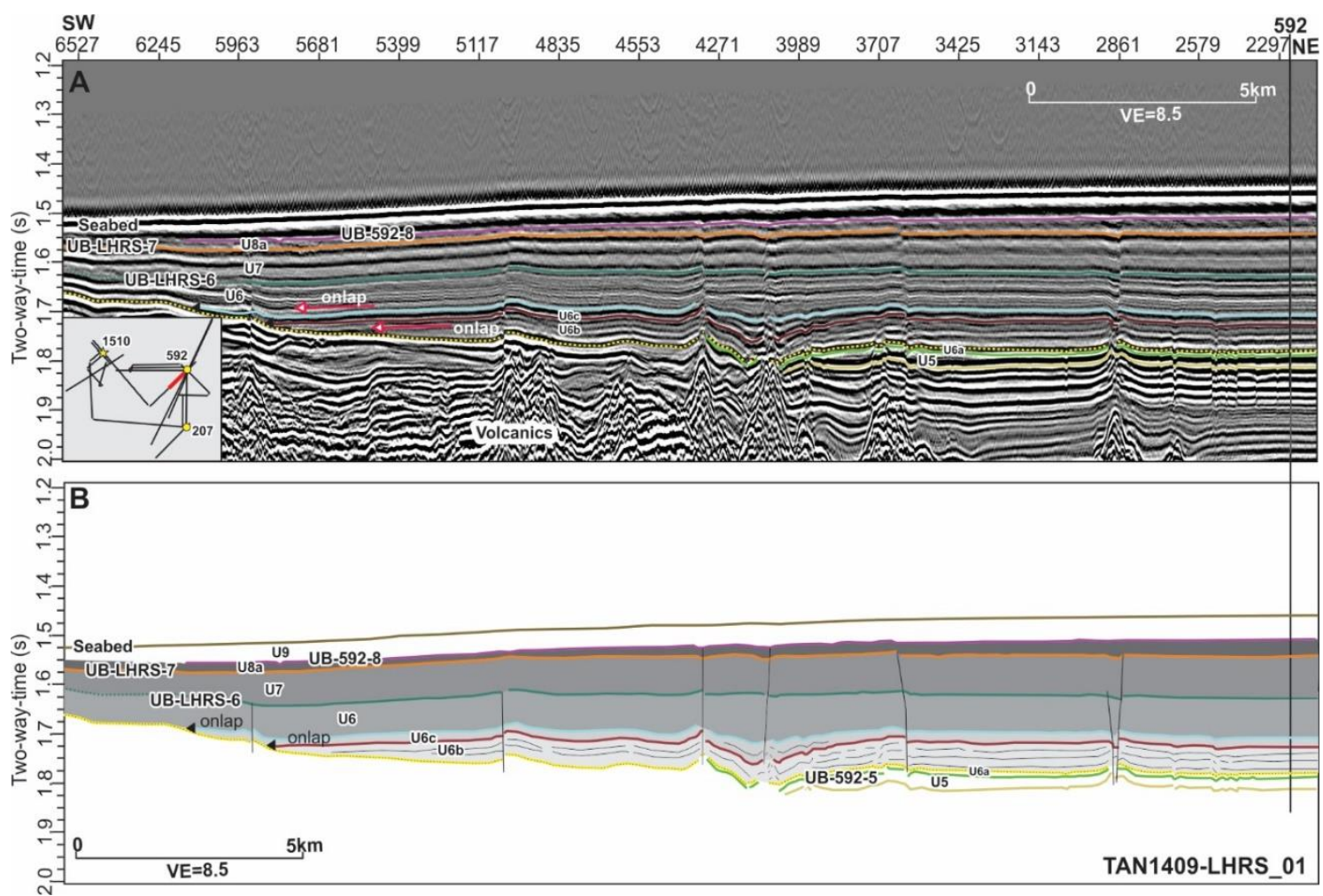

Figure 4.17. Seismic line TAN1409-LHRS_01 on the southern Lord Howe Rise at Site U592, (A) seismic reflection image, and (B) sketch of onlapping section just above Miocene unconformity (black yellow dash line).

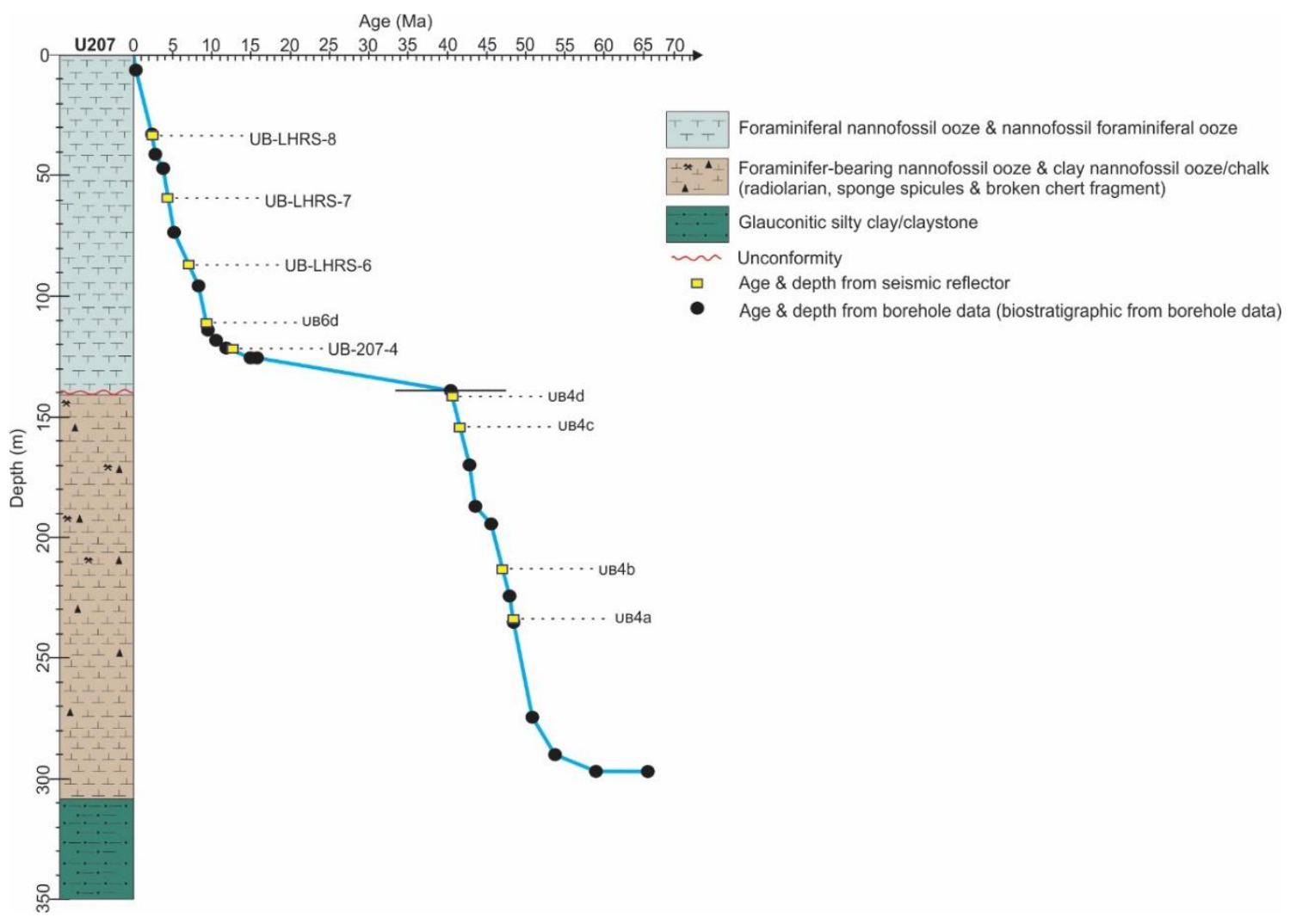

Figure 4.18. Borehole IODP DSDP 207 age-depth relationship. TWT seismic reflectors were converted to depth using velocity model (Sutherland et al., press. comm. 2019). 


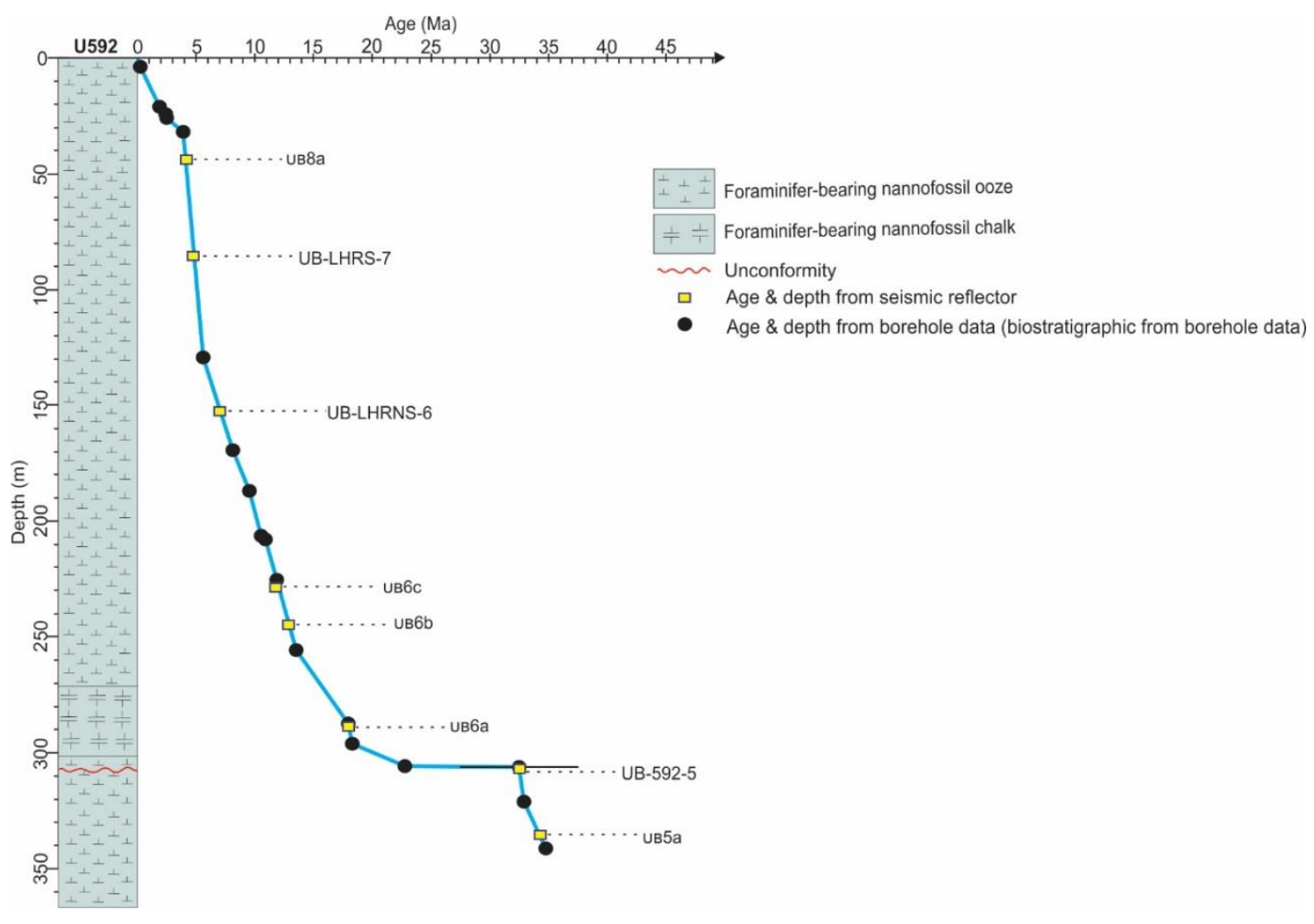

Figure 4.19. Borehole DSDP 592 age-depth relationship. TWT seismic reflectors were converted to depth using velocity model (Sutherland et al., press. comm. 2019).

\subsubsection{Burial analysis}

Sites U1510, 592 and U207 had variable mass accumulation rates (MAR) over time (Fig. 4.20). The MAR started to fluctuate about 50 to $42 \mathrm{Ma}$ (early to middle Eocene) and reached a peak of up to $43 \mathrm{~kg} \mathrm{ky}^{-1} \mathrm{~m}^{-2}$. Between middle to late Eocene ( 38 to $35 \mathrm{Ma}$ ), rates of accumulation dropped significantly from about 43 to $3 \mathrm{~kg} \mathrm{ky}^{-1} \mathrm{~m}^{-2}$ and it appeared to increase slightly up to about $15 \mathrm{~kg} \mathrm{ky}^{-1} \mathrm{~m}^{-2}$ in the early Oligocene $(\sim 32 \mathrm{Ma})$ then fell to $2 \mathrm{~kg} \mathrm{ky}^{-1} \mathrm{~m}^{-2}$. Between early Oligocene and early Miocene near constant MAR was 2 to $4 \mathrm{~kg} \mathrm{ky}^{-1} \mathrm{~m}^{-2}$. During Miocene time ( 18 to $5 \mathrm{Ma}$ ), MAR fluctuated considerably reaching a peak of up to $30 \mathrm{~kg} \mathrm{ky}^{-1} \mathrm{~m}^{-2}$ and dropped to about $19 \mathrm{~kg} \mathrm{ky}^{-1} \mathrm{~m}^{-2}$ in late Pliocene and Pleistocene time. Each of the sites is marked by lower accumulation rates of nearly 4 to $7 \mathrm{~kg} \mathrm{ky}^{-1} \mathrm{~m}^{-2}$ since 3 to $4 \mathrm{Ma}$. 
LHRN and LHRS have late Miocene peaks in MAR. LHRS has higher MAR in Eocene time compared to LHRN and this is presumably due to its oceanographic setting (mainly biogeneic sediment). This may relate to bottom current intensit in the region, creating a major hiatus where there was a break of sediment accumulation between late Eocene, early Oligocene and lower Miocene.

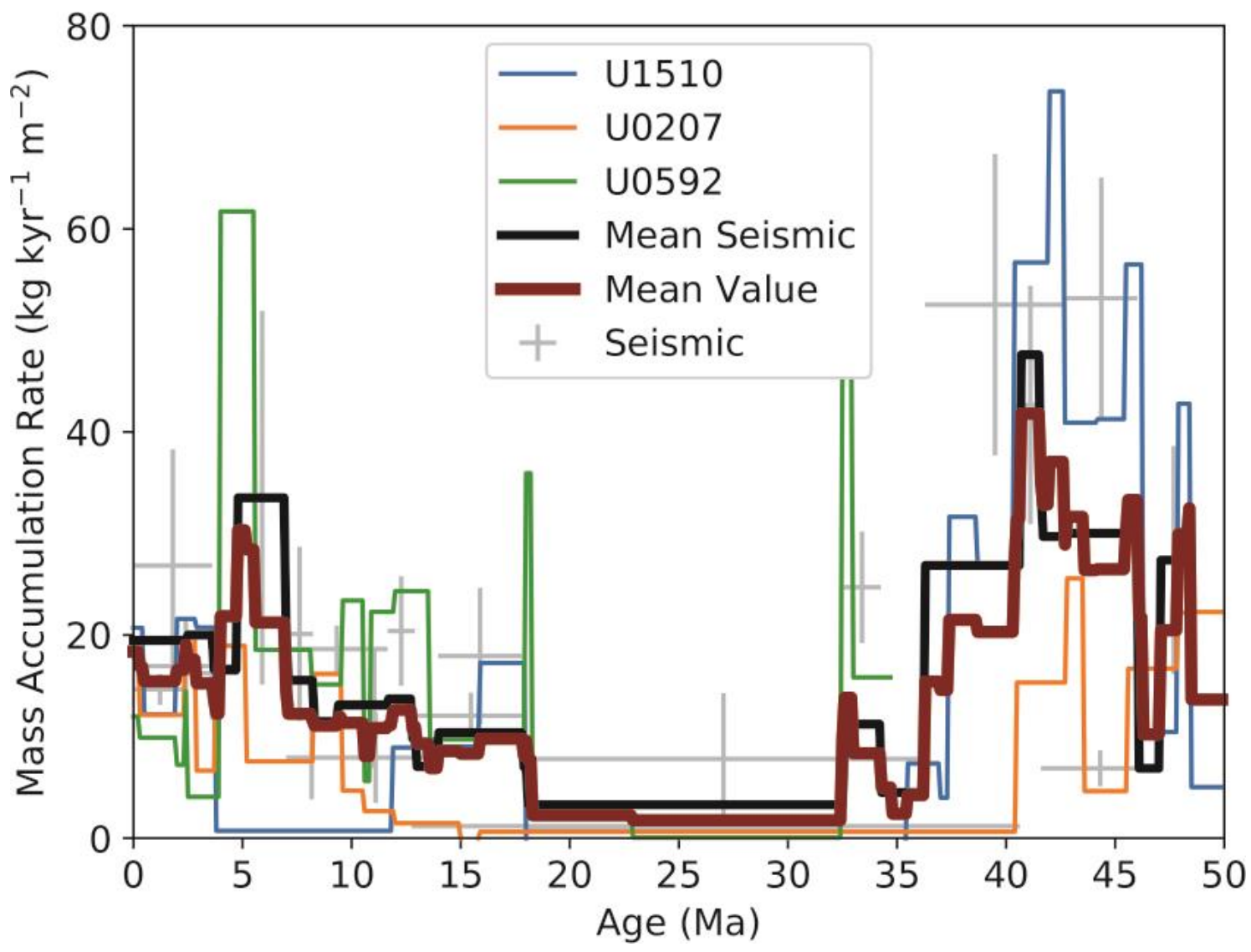

Figure 4.20. The Line graph illustrates a mass accumulation rate over time for the boreholes and seismic reflectors on the southern Lord Howe Rise. Grey crosses are mass accumulation rate from seismic units (horizontal $=$ age range of the unit for the top and the bottom \& vertical = standard deviation of the mass accumulation rate actual lateral variability). The solid black line is the mean value of seismic reflector data and the solid red line is the average of seismic and well data. 


\subsection{Northern New Caledonia Trough (NCTN)}

The northern New Caledonia Trough was mapped over about $1500 \mathrm{~km}^{2}$ with age and sediment calibration provided by Site U1507. Examination of 2D seismic reflectors allowed description of four bounding surfaces (UB-NCTN-5 to UB-NCTN-8) and five seismic units. These five seismic units contain nine sub-units or facies (Fig. 4.21). These are all subunits of the regional Zealandia U1 megasequence.

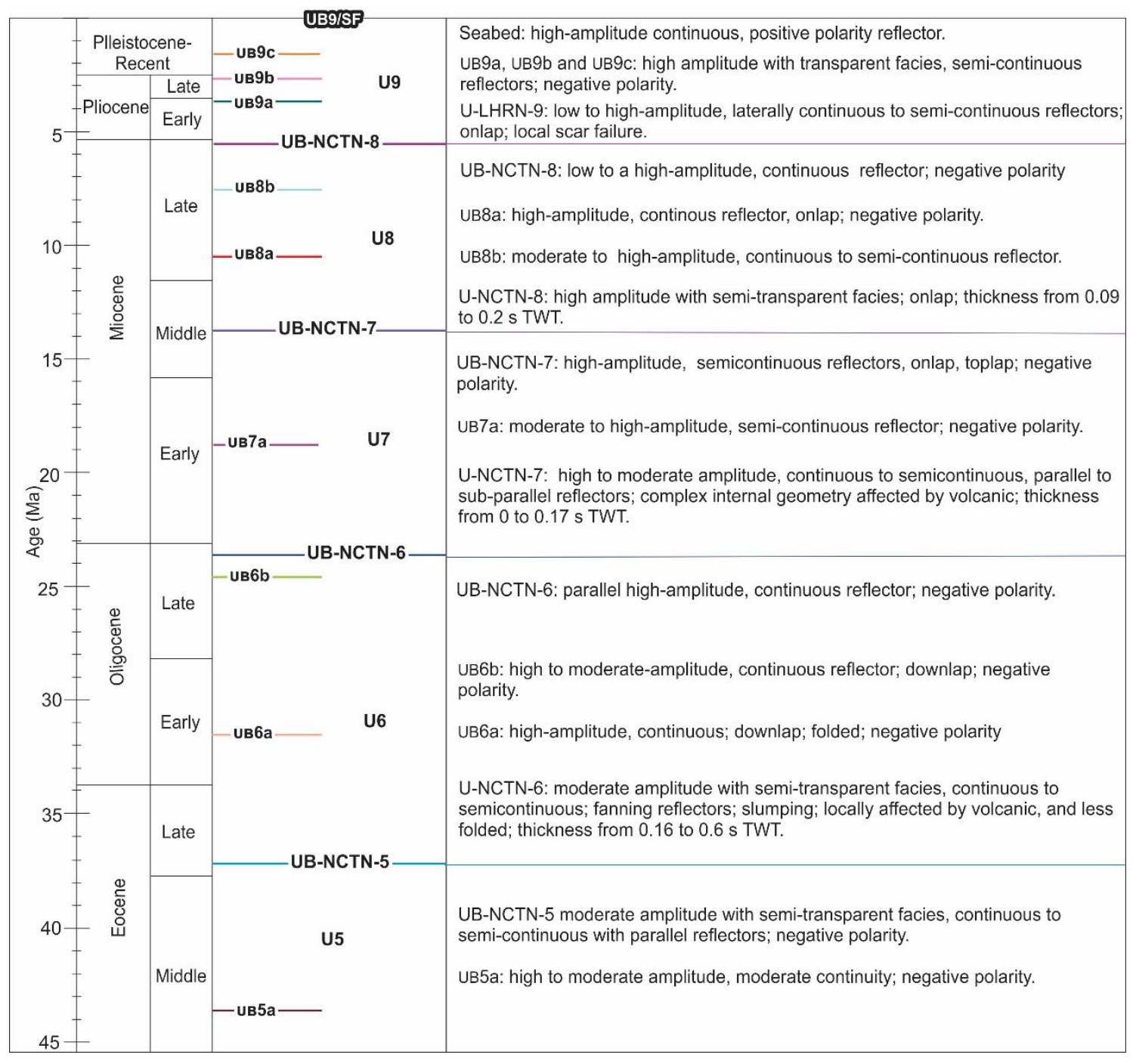

Figure 4.21. Seismic stratigraphy for northern New Caledonia Trough near Site U1507. 


\subsubsection{Result of seismic stratigraphy interpretation}

Eocene and Oligocene chalk and limestone correlates with Seismic Units 5 (UNCTN-5) and 6 (U-NCTN-6). The age of U-NCTN-5 is 43 to $37 \mathrm{Ma}$ (Fig. 4. 24), and UNCTN-6 is at 37 to $23.6 \mathrm{Ma}$. Eocene-Miocene (36-20 Ma) strata at borehole U1507 contained clayey chalk and volcanic turbidites (Fig. 4.23 \& 4.25) (Sutherland et al., 2018a) derived from large sub-merged volcanoes west of the crest of Norfolk Ridge. Seabed dredging from the southern end of this volcanic chain yielded a volcanic age of $26 \mathrm{Ma}$ (Mortimer et al., 2014).

The Miocene succession correlates with Seismic Units 7 (U-NCTN-7) and 8 (UNCTN-8). U-NCTN-7 and U-NCTN-8 are conformable units that have an age of 23.5 to $5 \mathrm{Ma}$ and comprise clayey calcareous ooze/chalk (Fig. 4.24). U-NCTN-8 and U-NCTN7 contain reworked pelagic sediment. U-NCTN-8 is delimited at its top by a surface of truncation indicated by reflector toplap at the seabed (Fig. 4.24). Sub-units 7a (U-NCTN7a) and $7 b$ (U-NCTN-7b) are truncated by UB-NCTN-7, which marks the top of discontinuous moderate to high-amplitude reflectors (Fig. 4.23). There is probably erosion by flows at the base of U-NCTN-8. U-NCTN-7 and U-NCTN-8 are affected by small polygonal faults (Fig. 4.23).

The Pliocene to Recent correlates with Seismic Unit 9 (U-NCTN-9) and has an age ranged from 5 to 2 Ma containing calcareous ooze/chalk with clay and slumps (Fig. 4.24) affected by debris flow activity. Seismic sub-units 9c (U-NCTN-9c) and 9b (U-NCTN9b) within U-NCTN-9 (at 5.0 to $4.8 \mathrm{~s}$ twt) are onlapped by a major infilling unit with horizontal, laterally continuous moderate-amplitude reflectors and intercalated bodies with transparent to chaotic facies (Fig. 4.23 \& 4.24). This unit drapes the underlying onlapping Seismic Unit 8 (U-NCTN-8) at CDP 2490 to 3015 (Fig. 4.24). Transparentchaotic facies within Seismic Unit 9 (U-NCTN-9) are interpreted as large-scale mass transport deposits.

The occurrence of common reworked sediment has been discussed in the report by Expedition 371 Scientists (Sutherland et al., 2018a). I reinterpret the top two first occurrence datums as reworked older sediment from the basin flank (Sutherland et al., 2018; Table 3, Pg. 15) and hence obtain a revised age model with more uniform 
sedimentation rate, shown by the straight red line between ages 3.8 and $1.6 \mathrm{Ma}$ (Fig. 4.25).

Gravity flows have produced localised erosion within U-NCTN-9 where axial channels or lateral lobes rework and entrain older sediment. The former abruptly pinch out laterally. Axial turbidite deposits of U-NCTN-9 pinchout laterally onto the slope with onlap configuration. Slope failure scars on the seabed are consistent with active downslope flow processes on the slope (Fig. 4.22).

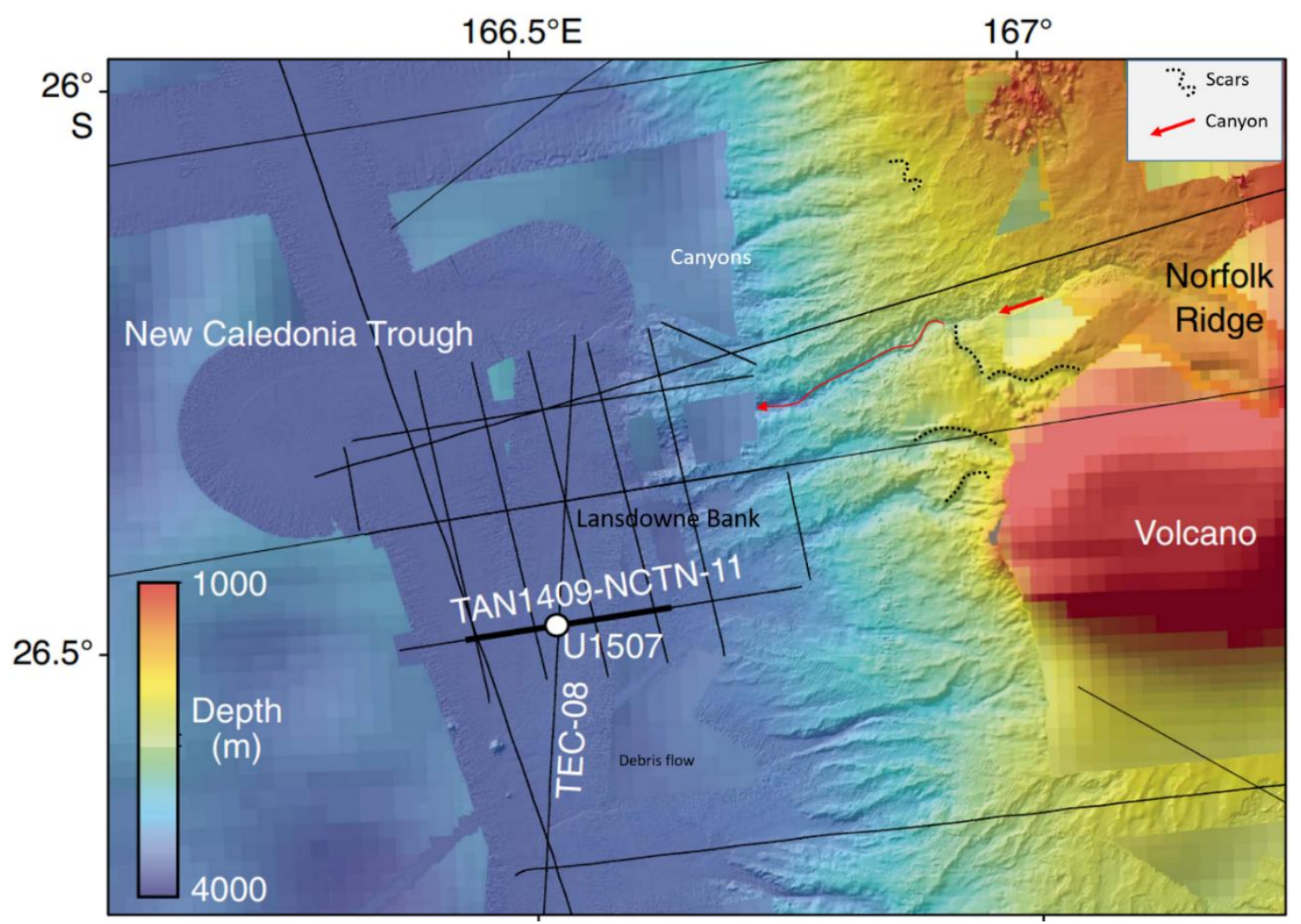

Figure 4.22. Bathymetry showing failure scars and small canyons at the lower part of Norfolk Ridge (Sutherland et al., 2018a)

Basin floor fans are derived from incised canyons on the lower part of Norfolk Ridge. Downslope of the arcuate escarpments seen on the bathymetry, erosional canyon scars are consistent with active downslope flow processes on the slope (Fig. 4.22). 


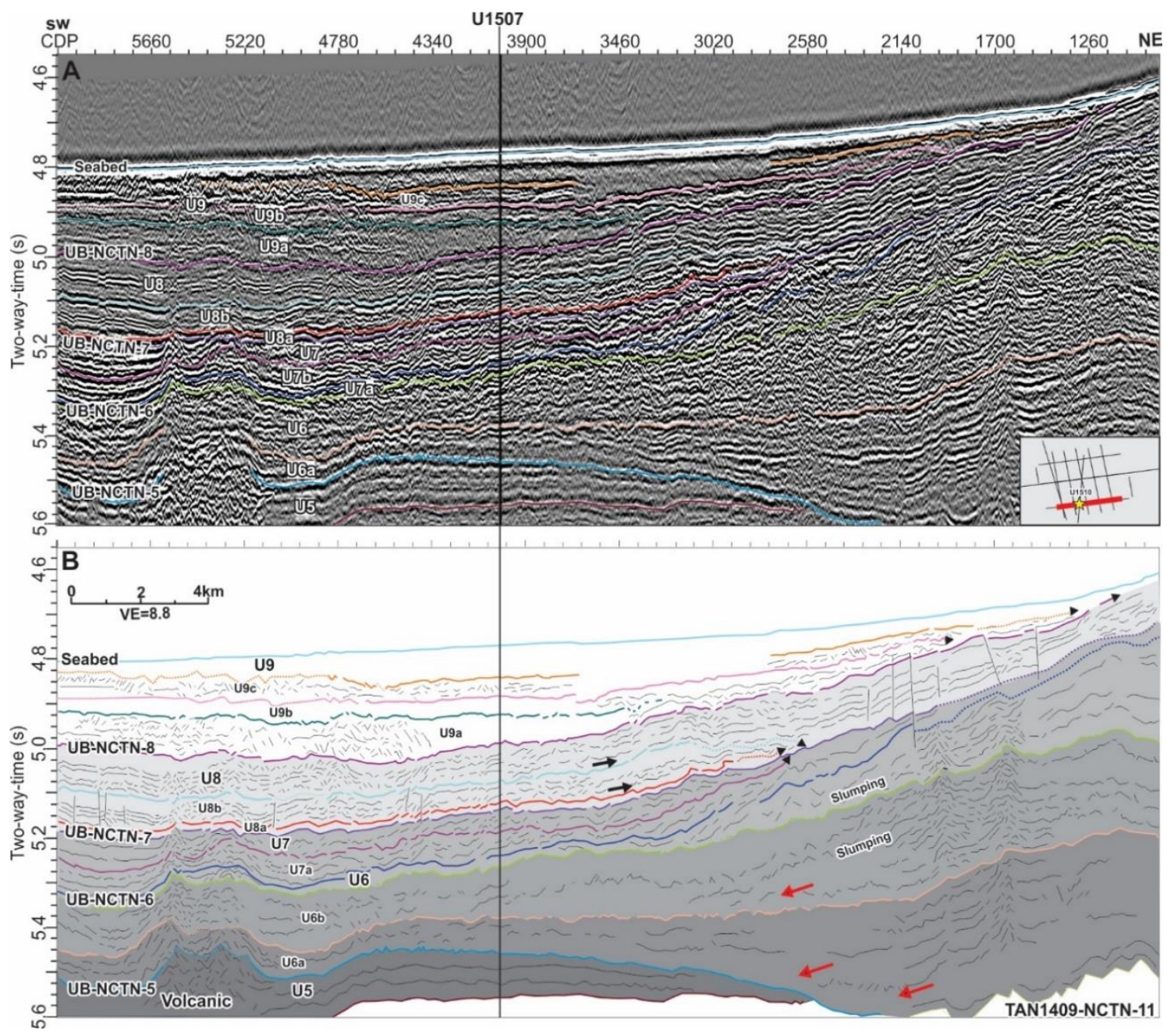

Figure 4.23. Seismic line line TAN1409-NCTN-11 at Site U1507, (A) seismic reflection image with horizons picked in colour, and (B) sketch of onlapping and downlapping strata near Site U1507. Stratigraphic onlaps are shown with small black arrow facing northeast and small two arrows with purple and blue colour are toplapping reflectors. Black line is polygonal faulting. 


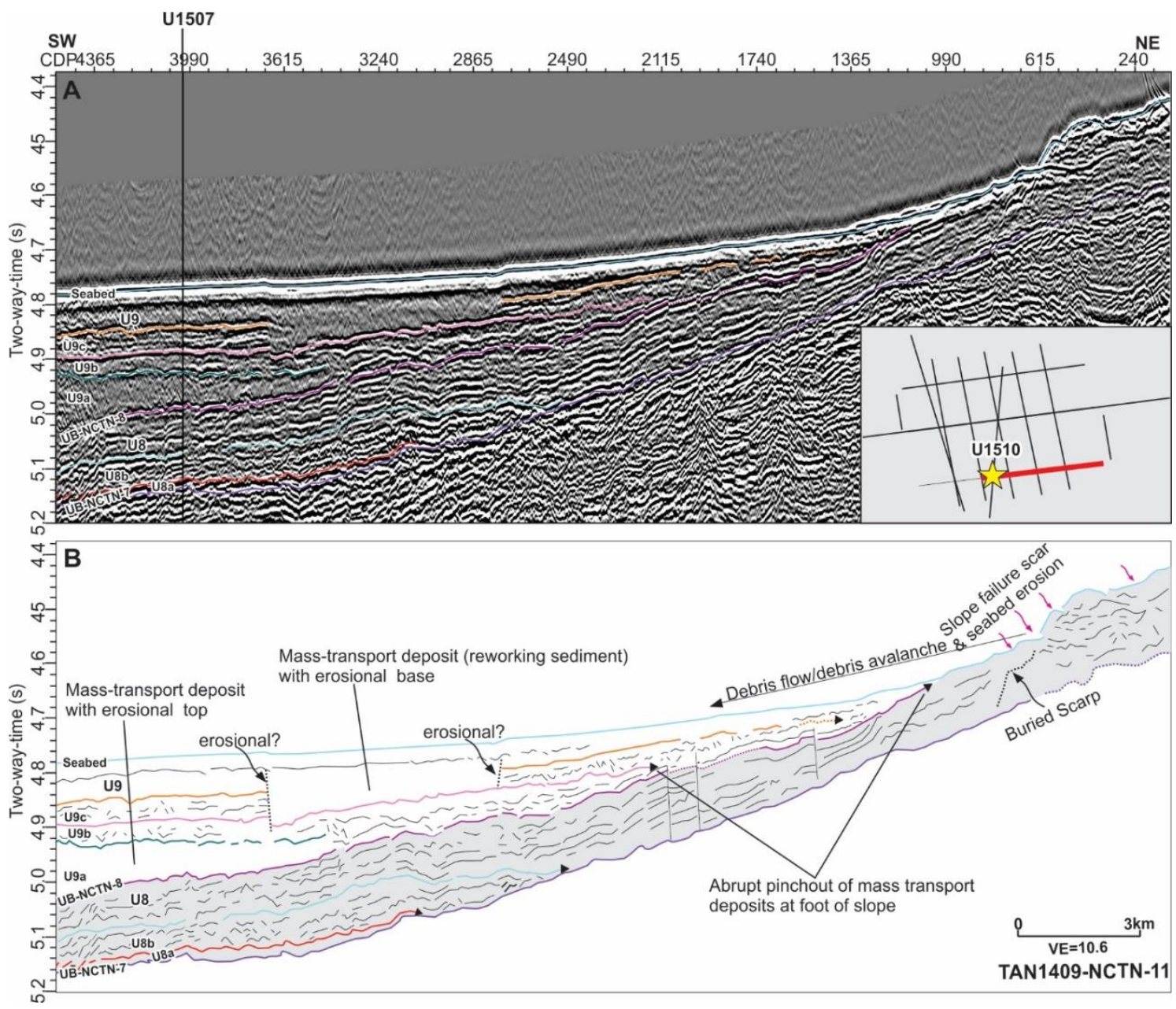

Figure 4.24. Seismic line TAN1409-011 shows deposition of reworking sediment at the basin; (A) seismic reflection image, and (B) interpreted illustrating the relative position of slope failure scars at seabed and pinchout or onlap mass transport deposits at the edge of the basin, and buried escarpments on the slope. 


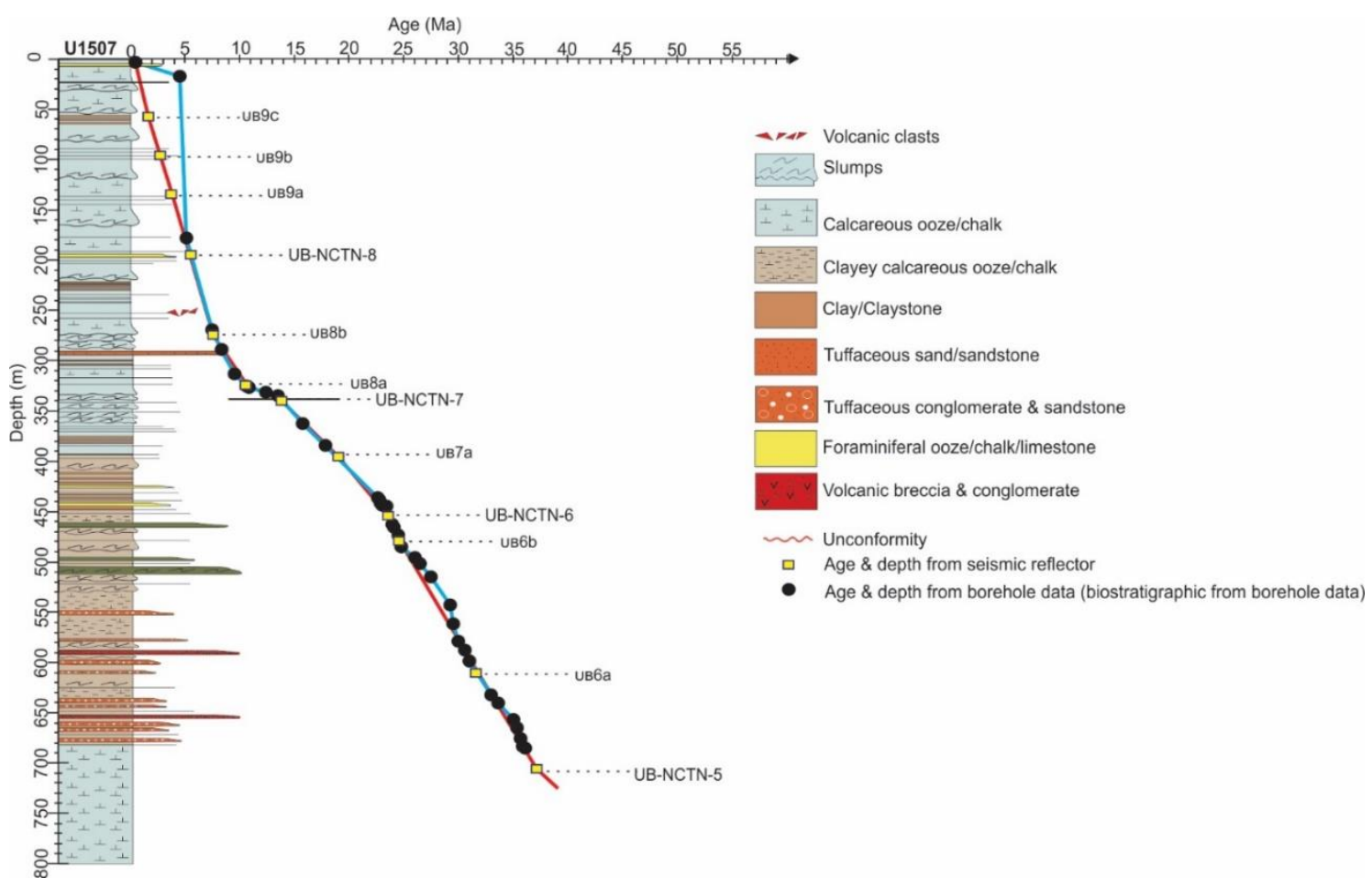

Figure 4.25. Borehole IODP U1507 showing depth-age relationship. Stratigraphy column shows lithology and biostratigraphic data and TWT (Sutherland et al., pers. comm. 2019; Sutherland, 2019b; Sutherland et al., 2018). Horizontal dash lines = seismic reflection/time horizons picked for units boundaries, red solid line=age model correlation for microfossil datum accounting for reworking (correction from U-NCTN-B9a to U-NCTN-B9c) and blue solid line= published age model from borehole data/sediment sampled at borehole U1507 (Sutherland, 2019b, Sutherland et al., 2018a).

\subsubsection{Burial analysis}

The mass accumulation rate (MAR) was calculated between seismic reflectors and borehole data (revised age model from microfossil datums). Figure 4.26 illustrates the result of the mass accumulation rates for Site U1507. In the early Eocene to late Oligocene, rapidly fluctuating MAR reached a peak of $79 \mathrm{~kg} \mathrm{ky}^{-1} \mathrm{~m}^{-2}$. The higher MAR during Eocene-Oligocene may relate to active uplift, erosion and volcanism activity near Norfolk Ridge. Then, it decreases and becomes constant between 23 and 11 Ma with an accumulation rate of 14 to $20 \mathrm{~kg} \mathrm{ky}^{-1} \mathrm{~m}^{-2}$. The late Miocene-Pliocene biogenic bloom signal is observed reaching a peak MAR of $50 \mathrm{~kg} \mathrm{ky}^{-1} \mathrm{~m}^{-2}$ at 5-7 Ma, and the Pleistocene rate has dropped to about $40 \mathrm{~kg} \mathrm{ky}^{-1} \mathrm{~m}^{-2}$ but is uncertain due to reworking of fossils and hence poor resolution of the age model. 


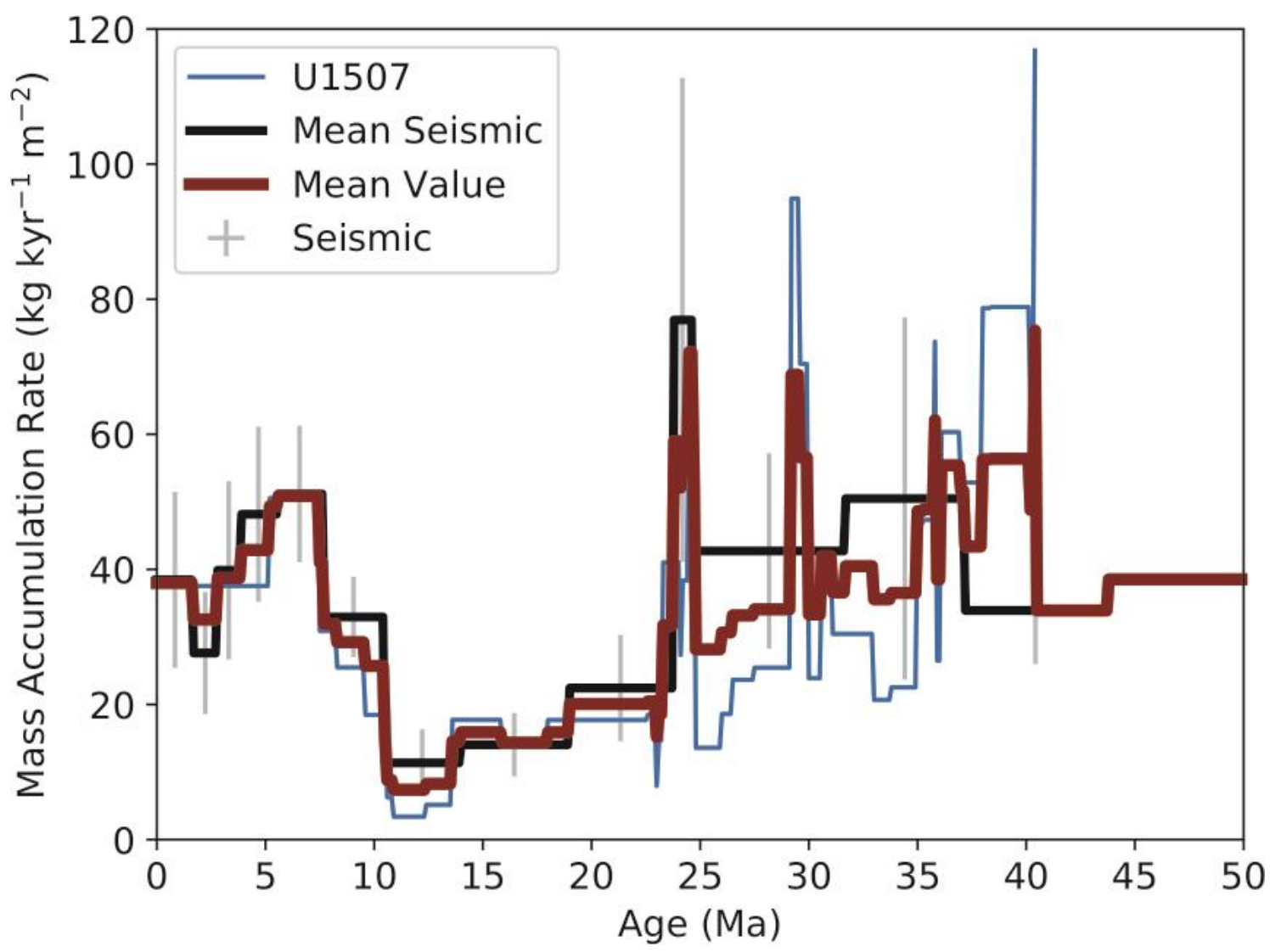

Figure 4.26. Line graph shows mass accumulation rate over time for the boreholes and seismic reflectors in northern New Caledonia Trough. Grey crosses are mass accumulation rate from seismic units (horizontal $=$ age range of the unit for the top and the bottom $\&$ vertical $=$ standard deviation of the mass accumulation rate actual lateral variability). The solid black line is the mean value of seismic reflector data and the solid red line is the average of seismic and well data. 


\subsection{Reinga Basin (REIN)}

Reinga Basin covers about $90,000 \mathrm{~km}^{2}$ but only about $30,000 \mathrm{~km}^{2}$ was mapped that can be tied to borehole U1508. Seismic reflector units U5-U9 are part of the ZealandiaU1 megasequence, but for this local analysis I adopt the nomenclature of Bache et al., (2012).

Five seismic unconformities (UB-REIN-4 to UB-REIN-8) were identified encompassing six seismic units (U-REIN-4 to U-REIN-9) and seven sub-units (Fig. 4.27 \& 4.28).

\subsection{1 $\quad$ Result of seismic stratigraphy interpretation}

The Eocene succession correlates with Seismic Units 4 (U-REIN-4) and 5 (U-REIN5) (Fig. $4.27 \& 4.28$ ). Seismic Unit 4 (U-REIN-4) is correlated with early to middle Eocene pelagic carbonate deposition (Sutherland, 2019c, Sutherland, 2019b). U-REIN-4 is 43.4-36.2 Ma and contained clayey nannofossil ooze/chalk and limestone (Fig. 4.30). U-REIN-5 has an age of 36.2-33.4 Ma and is composed of nannofossil chalk. U-REIN-5 onlaps folded U-REIN-4 near Site U1508. Faults and folds observed within U-REIN-4 and U-REIN-5 created accommodation space that filled by downslope sediment transport from newly-formed sediment sources (reworking), resulting in deposition of U-REIN-5. Compression appears to be accommodated by fault propagation folds in the NE that located under South Maria Ridge (Fig. 1.1, 4.28 \& 4.29). 


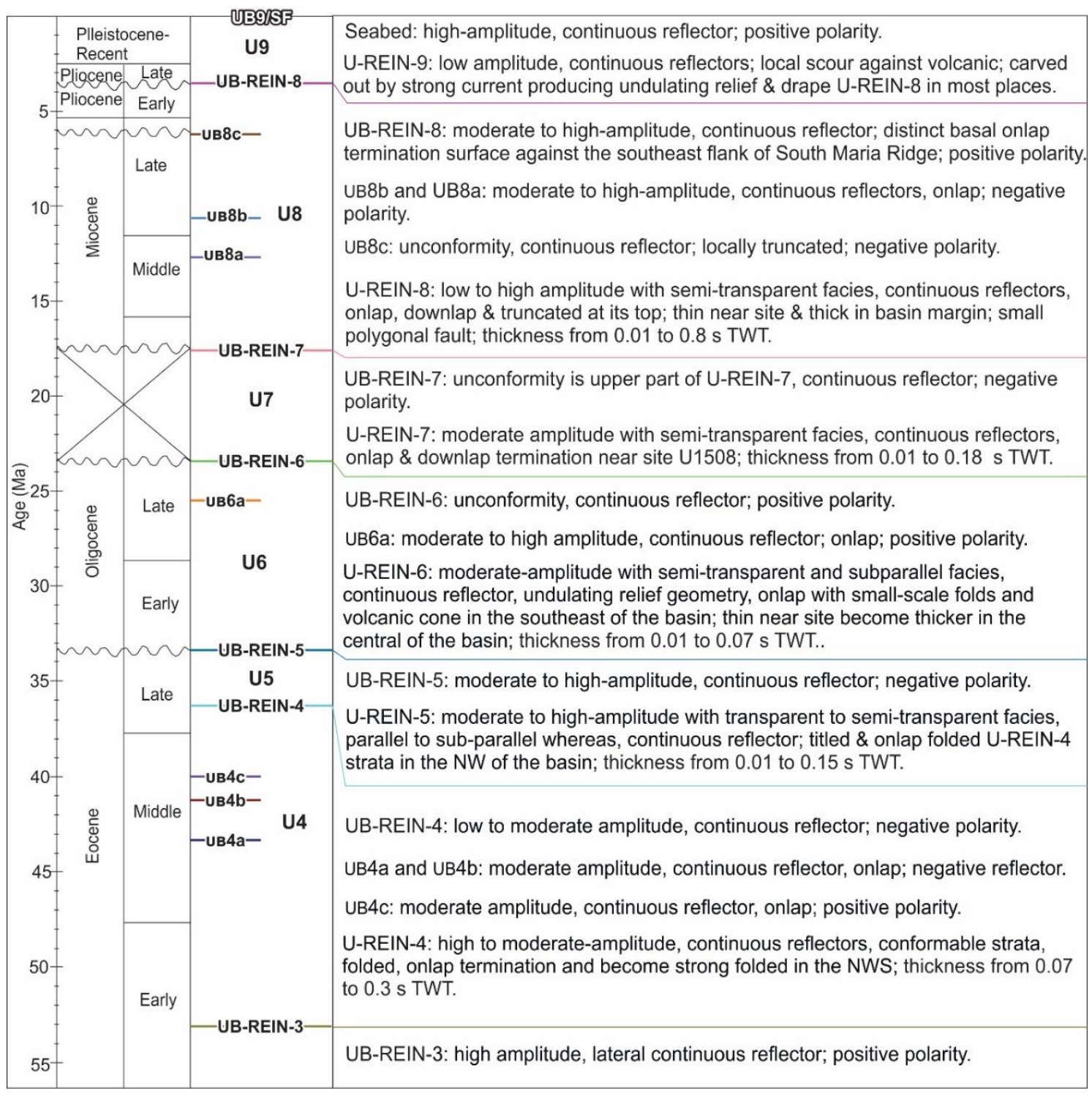

Figure 4.27. Seismic stratigraphy for Reinga Basin near Site U1508 (after Orr et al. 2020). The units adopt the nomenclature of Bache et al (2012a, b). 


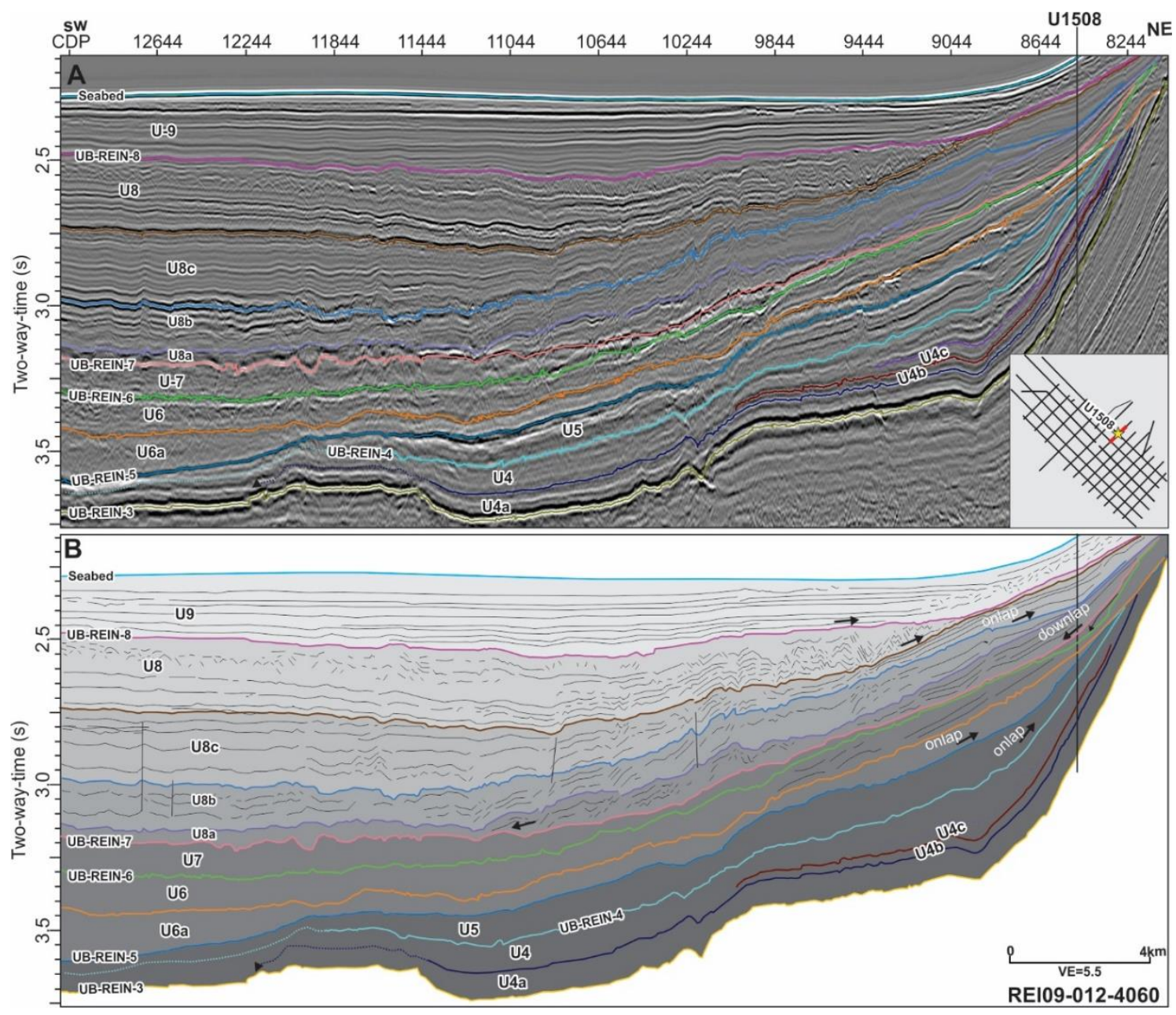

Figure 4.28. Seismic reflection line REIN09-012, (A) seismic reflection image, and (B) sketch of onlapping and channelling fill geometries.

The Oligocene sequence correlates with Seismic Unit 6 (U-REIN-6) (Fig. $4.27 \&$ 4.28). U-REIN-6 is defined to have age range from 33-23 Ma. Dredge sediment samples contain foraminiferal ooze and chalk with clay and volcanic clast with age 28-23 Ma (Sutherland, 2019c). Reworked microfossils observed at Site U1508 provide evidence for nearby shallow-water, consistent with evidence for nearby wave ravinement of South Maria Ridge (Fig $1.1 \&$ 4.28). Overlying younger strata than U-REIN-5 onlap features interpreted as volcanoes (Orr et al., 2020) (Fig. 4.29) indicating volcanism began during the hiatus at Site U1508 at 34-28 Ma. 


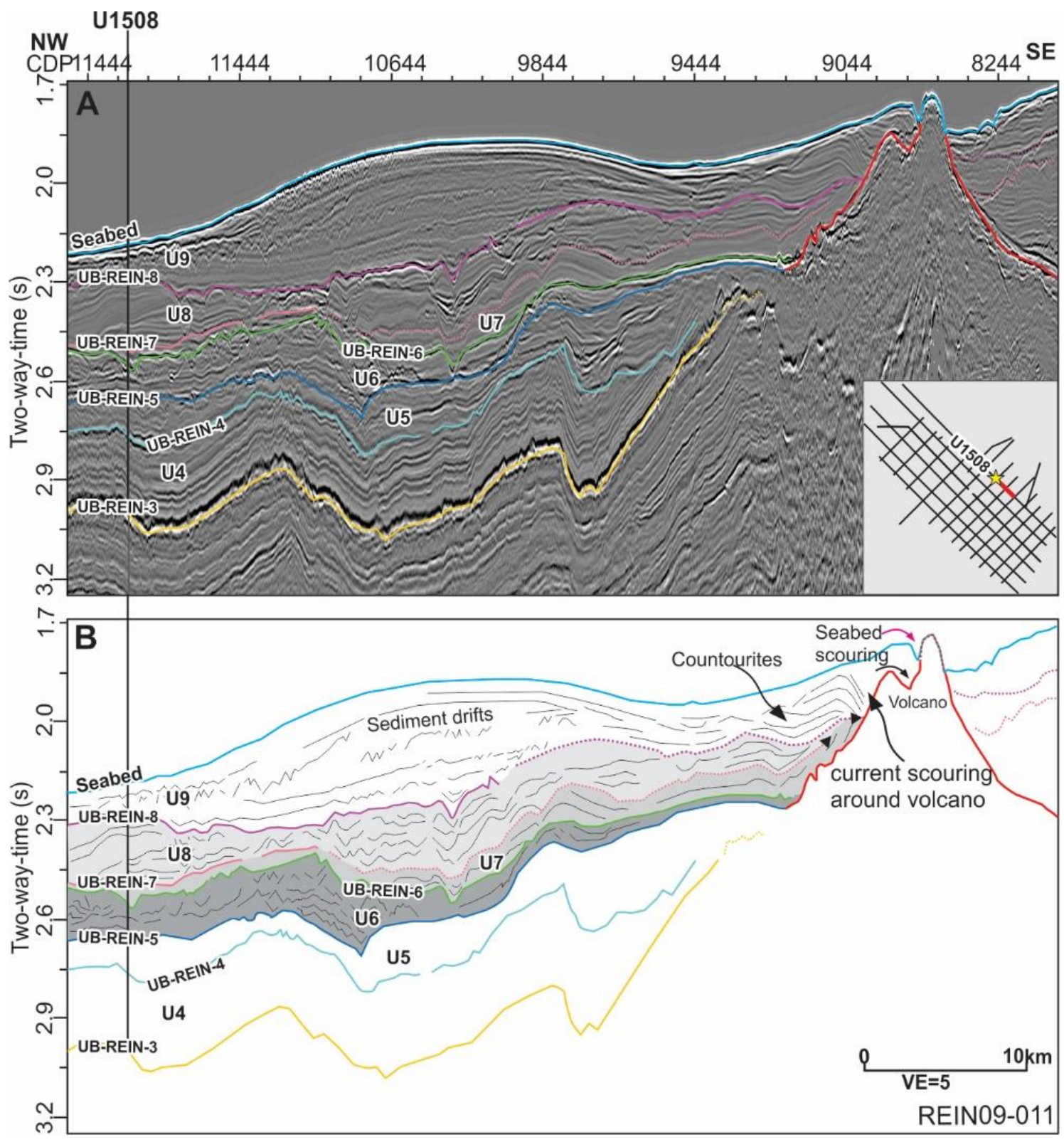

Figure 4.29. Seismic reflection line REIN09-011 illustrates horizons picked and seismic units across the site U1508 in the Reinga Basin; (A) seismic reflection image and, (B) interpreted seismic reflection presenting key seismic stratigraphic relationship along the strike. UB-REIN-5 appeared to correspond with the base strata, UB-REIN-6 and UB-REIN-7 onlap the volcano in the SE where seabed seems scouring against the volcano.

The Miocene to Recent sequence correlates with Seismic Units 7 (U-REIN-7), 8 (UREIN-8) and 9 (U-REIN-9). U-REIN-7 and U-REIN-8 tie to borehole U1508 where they are 17.3-6.1 Ma containing foraminiferal ooze/chalk with clay interbedded thin foraminiferal ooze/chalk with sand (Fig. 4.30). Downlapping reflectors within U-REIN7 are consistent with evidence for volcanic input at borehole U1508 (Fig. $4.28 \& 4.29$ ). U-REIN-8 is variable across Reinga Basin. It is conformable in most places and drapes older units, but is locally truncated by UB-REIN-8 (Fig. $4.27 \& 4.28$ ). U-REIN-9 
comprises countourites and a channel complex (Fig. 4.29). U-REIN-8 and U-REIN-9 contain undulating reflectors that drape older sediment. U-REIN-8 and U-REIN-9 are composed of pelagic ooze and bioclastic ooze (Fig. 4.30).

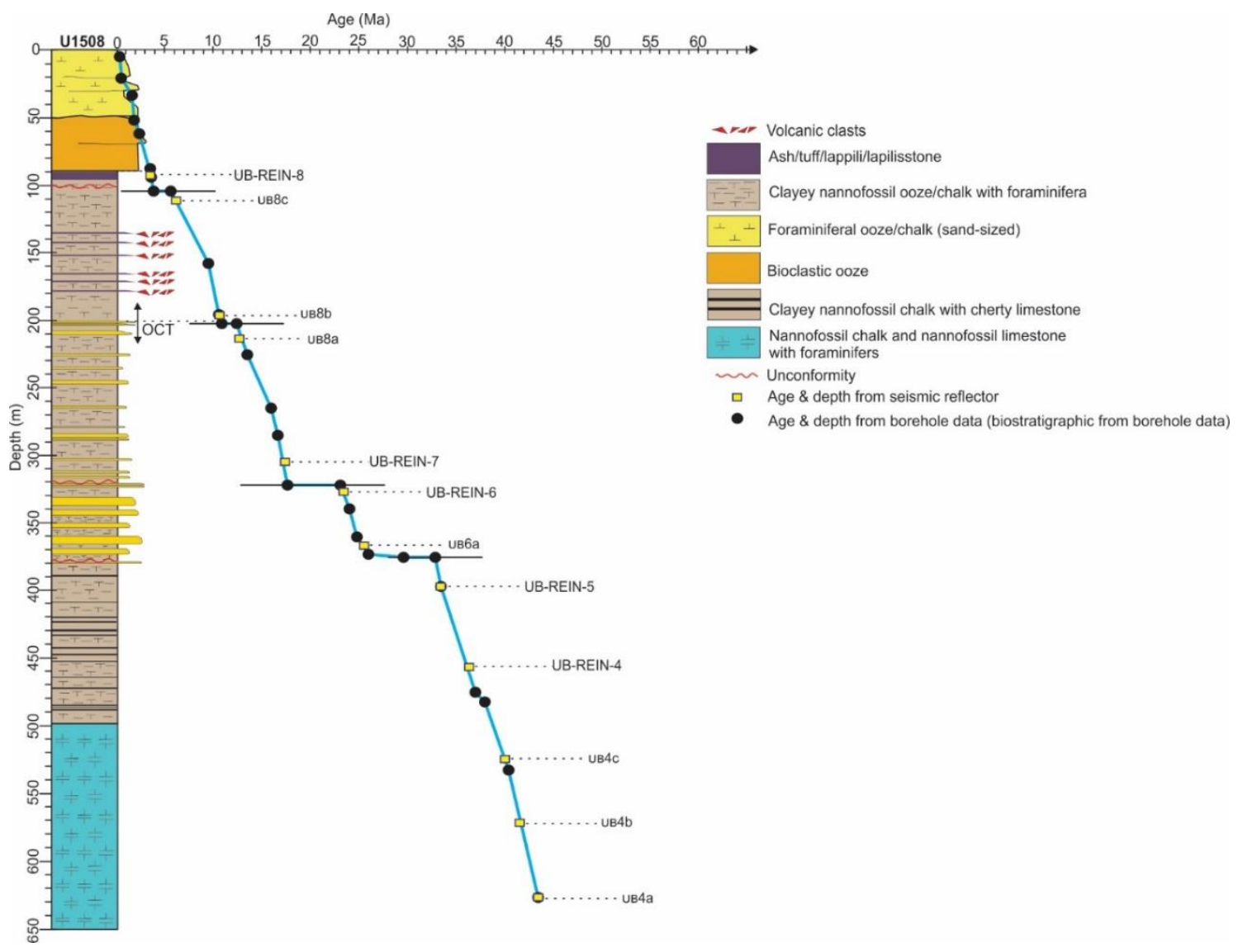

Figure 4.30. Borehole IODP U1508 age-depth relationship. TWT seismic reflectors were converted to depth using velocity model (Sutherland et al., press. comm. 2019).

Examination of seismic stratigraphy allowed division of seismic units into three categories. Faulted and folded strata are older than the tectonic event (Orr et al., 2020). Syn-tectonic growth strata record deformation and younger strata are undeformed (Fig. 4.28). U4 to U5 are composed of folded, faulted, and onlapping reflectors that record progressive deformation (Fig. 4.29). U6 to U7 are fanning reflectors, that onlap and downlap, and have volcanic and clastic input (Sutherland, 2019c). Finally, U8 to U9 are drape strata with an architecture related to variable bottom current strength and changes in sea level and sediment supply. 


\subsubsection{Burial Analysis}

Sedimentation rate calculation at Site U1508 reveals a significant result: seismic reflectors mapping gives an opposite result to that obtained from borehole data (Fig. 4.31). In the late Eocene ( $33 \mathrm{Ma}$ ), mass accumulation rate (MAR) fluctuated up to about $62 \mathrm{~kg} \mathrm{ky}^{-1} \mathrm{~m}^{-2}$ and was similar in the late Oligocene ( $\left.26 \mathrm{Ma}\right)$. In contrast, Miocene values vary considerably, depending on whether they are calculated from seismic or borehole data (Fig. 4.31). The mean value shows that MAR is $180 \mathrm{~kg} \mathrm{ky}^{-1} \mathrm{~m}^{-2}$ in late Miocene to early Pliocene.

Hence, the observations show that when a hiatus is present on the flank of South Maria Ridge (Site U1508), a thick unit accumulates in the deepest part of the basin. Very low sedimentation rates on the ridge correspond to high sedimentation rates in the basin (Fig. $4.28 \& 4.31$ ). It implies some role of the variable Tasman Front (Fig. 2.4), which is scouring and reworking sediment from the ridges into the basin.

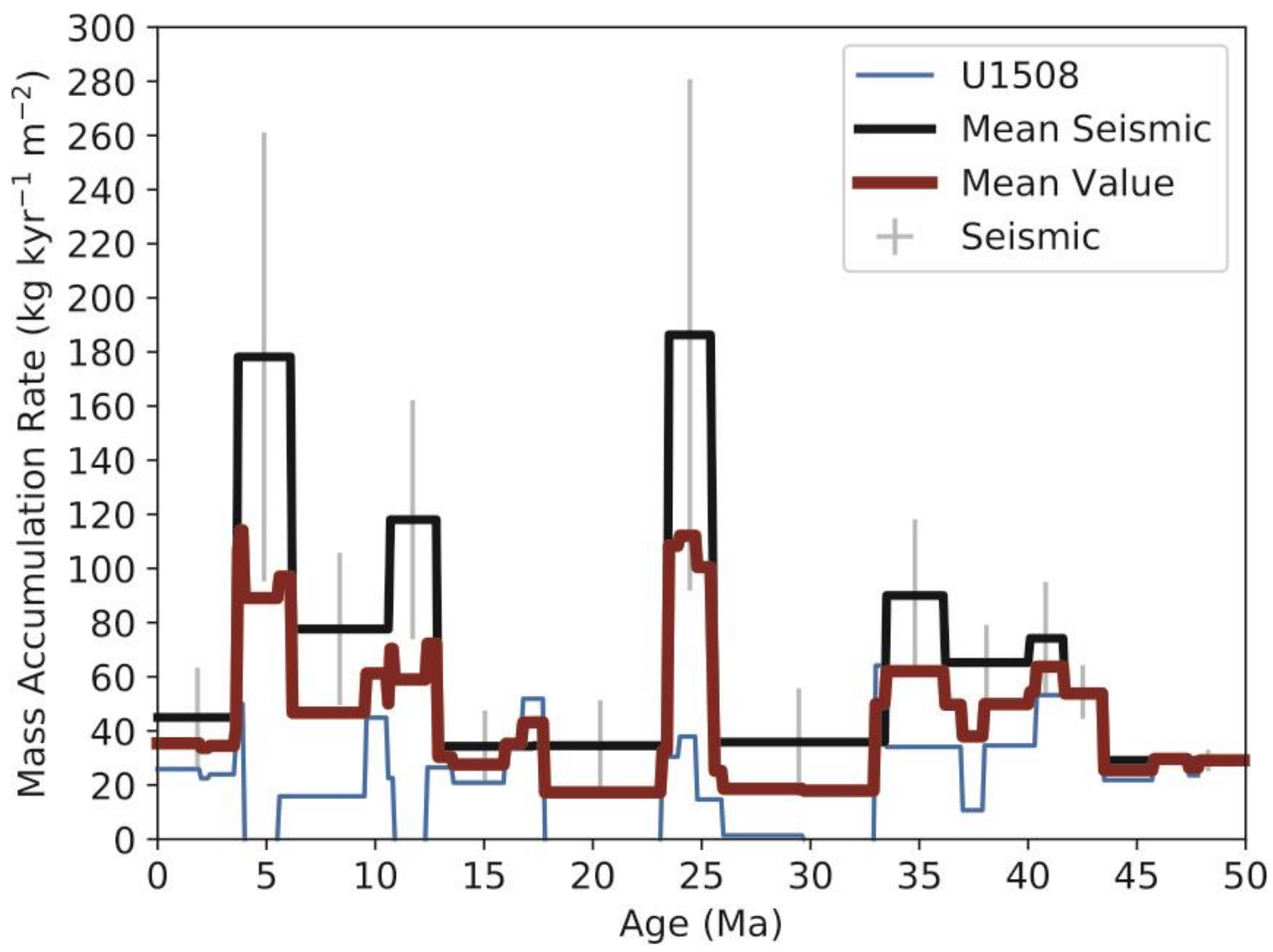

Figure 4.31. Line graph shows mass accumulation rate over time for the boreholes and seismic reflectors data in the northern New Caledonia Trough. Grey crosses are mass accumulation rate from seismic units (horizontal $=$ age range of the unit for the top and the bottom \& vertical $=$ standard deviation of the massive accumulation rate actual lateral variability); blue line is Site U1510 The solid black line is the mean value of seismic reflector data and the solid red line is the average of seismic and well data. 


\subsection{Interpretation and conclusion}

Global climatic events played a key role in shaping stratigraphic sequences of the northern Zealandia region. Kennett (1977) summarised instances of climatic change through the Oligocene to Eocene when the tectonic separation of Antarctica and Australia caused regional changes in oceanic circulation patterns. During this time there was a rapid transition from Eocene siliceous bathyal sediments to Oligocene marine carbonate-rich rocks (Kennett, 1980).

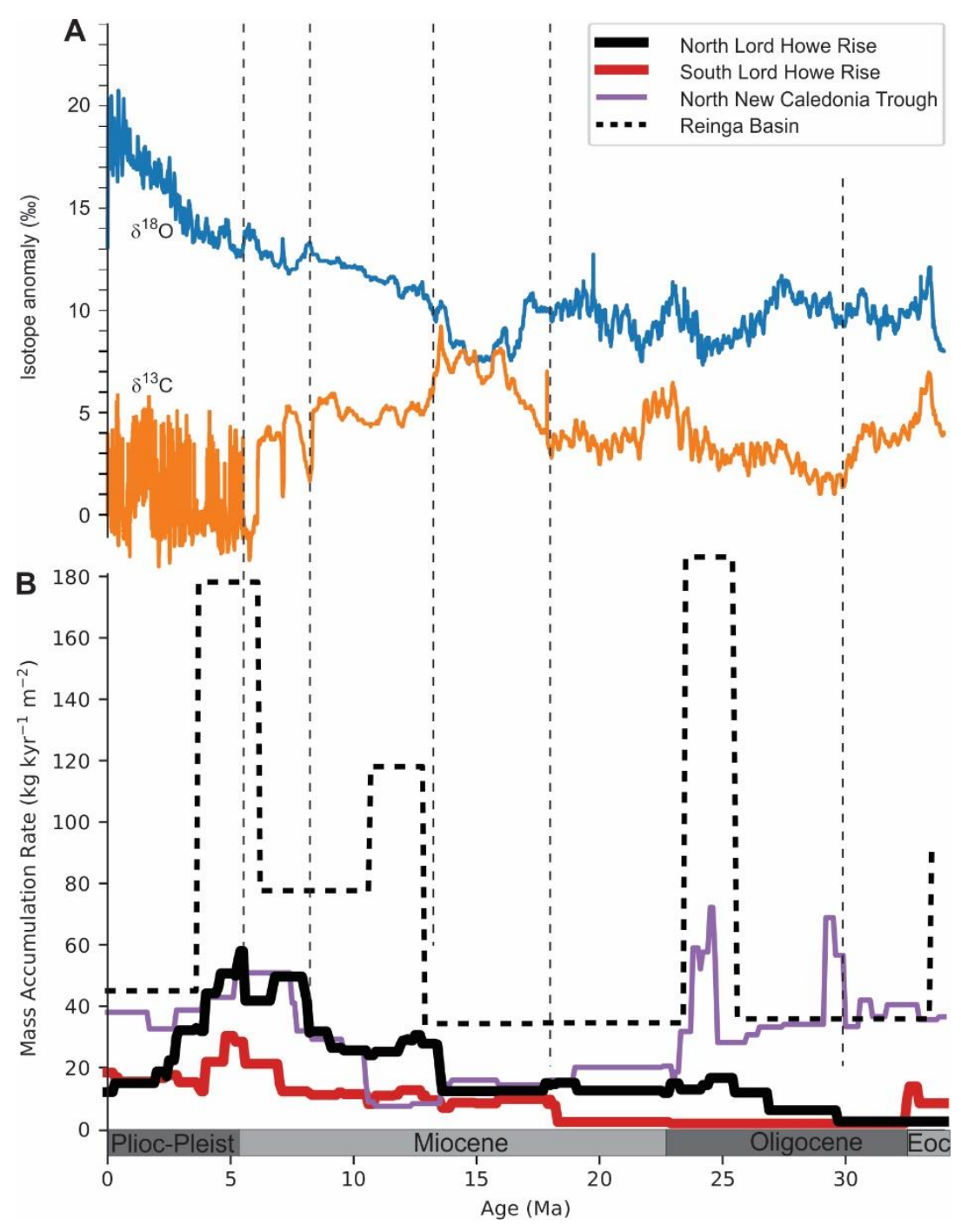

Figure 4.32. Summary of MAR data in northern Zealandia; (A) Global isotopes curve (Zachos et al., 2008a) shows carbon isotope $\left(\delta^{13} \mathrm{C}\right)$ which is yellow curves and oxygen isotope $\left(\delta^{18} \mathrm{O}\right)$ in blue and (B) Mass accumulation rates for the LHRN (solid black line), LHRS (solid red line), NCTN (solid purple line) and REIN (solid dash line). LHRN, LHRS and NCTN are defined using seismic and boreholes data but Reinga Basin is only seismic data and represents MAR in the basin depocentre only. 
Significant change in the ocean and sediment patterns occurred in the Neogene. Warmer conditions were temporarily developed during the mid-Miocene ( 17-15 Ma) followed by a long-term global climate deterioration (Fig. 4.32) (Zachos et al., 2008b).

Sedimentation rates in the study area are consistent across the region and correlate with periods of global climate change. LHRN, LHRS, NCTN and REIN have MAR peaks during the earliest Pliocene to the latest Miocene (Fig. 4.32). Highest values in LHRN and REIN correspond to regions of high Tasman Front flow (Fig. $2.2 \& 2.4$ ).

The South Pacific Gyre is the large-scale circulation of tropical water that accumulates in the western Pacific and then flows southward to include the East Australia Current and Tasman Front on its way to mixing with the Antarctic Circumpolar Current (Fig. 2.2 \& 2.4) (Rintoul et al., 2001, Ganachaud et al., 2014, Ganachaud et al., 2007a, Mulhearn, 1987). Strong currents result in biological productivity where upwelling of deep nutrient-rich water mixes with shallow subtropical water at local divergent zones (controlled by seabed topography and fluid mechanics).

The MAR results calculated here show that biogenic input (carbonate and biosilica) increased substantially between 9 and $3 \mathrm{Ma}$, consistent with observations at Site U590 that suggest increased upwelling within the Tasman Front at that site at that time (Grant and Dickens, 2002). This phenomenon of Latest Miocene to Early Pliocene increased productivity is observed throughout the global tropical and subtropical ocean and has been termed the 'Late Miocene Biogenic Bloom' (Dickens and Owen, 1999, Peterson et al., 1992, Farrell et al., 1995, Van Andel et al., 1975, Rea and Snoeckx, 1995, Dickens and Owen, 1996, Grant and Dickens, 2002).

How and why the climate system was working at that time is not entirely clear, and this issue is outside the scope of my thesis. However, it is interesting to note that MAR observations are consistent with those elsewhere and indicate a signal of global climate change. It is significant for petroleum prospectivity because sedimentation rate was high and water temperatures were likely to have been relatively warm in the early Pliocene. This means that peak thermal maturity of petroleum source rocks was likely achieved at 4-2 Ma across much of this region. 


\section{Petroleum System Analysis}

\subsection{Introduction}

The objective of this chapter is to present stratigraphic correlation (locally and regionally) and petroleum system analysis of northern Zealandia and hence conclude how prospective for petroleum are different parts of the region, and what play types might exist.

Northern Zealandia may have a working petroleum system, and it has petroleum production in northern New Zealand (Collot et al., 2009, Rouillard et al., 2014, Rouillard et al., 2015). Hence, the petroleum industry has been interested in the region since the 1970s; however, it has left the area largely unexplored. Northern Zealandia comprises sedimentary basins that may share a common geological origin with the Taranaki Basin in New Zealand and Gippsland Basin in southern Australia. Petroleum systems have been proved by discoveries since 1969 (McBeath, 1977, Mehin and Bock, 1998, Skinner, 2008). The Taranaki Basin is the only hydrocarbon-producing basin in New Zealand and the Maui field was discovered in 1969 (Skinner, 2008, McBeath, 1977). The total production in the Maui field was about 4 TCF (trillion cubic feet) of gas and $300 \mathrm{Mbbl}$ of light oil. The production in Gippsland Basin was approximately 3,450 MMBO (million barrels of oil) and 4.8 TCF of gas, with remaining reserves totalling 629.9 MMBO and 4.8 TCF (Mehin and Bock, 1998).

Further northwest, numerous oil and gas fields have been discovered in the Timor Sea (Bonaparte Basin) and Papua New Guinea (PNG) (Papuan Basin). In Bonaparte Basin, the Bayu-Undan field was discovered in 1995, and the field reserves are 350-400 million barrels of hydrocarbon liquids and 3.4 TCF of gas (Brooks et al., 1996, Ledlow et al., 2008). Production started in 2004 with total production of 115,000 barrels per day of condensates and LPG. In Papua New Guinea, the first commercial oil discovery was at the Kutubu field in the Southern Highlands Province in the late 1980s, and production commenced in 1991 with about 200 million barrels produced in total (Rickwood, 1990, Owen and Lattimore, 1998). 
Northern Zealandia has had no petroleum exploration borehole drilled, but in the southern part it has Romney-1 (deepwater Taranaki Basin) and Waka Nui-1 well (offshore Northland Basin). Until the REIN09, TAN1409, TECTA survey, and IODP drilling, there was no way to tie seismic surveys together or tie with biostratigraphic or lithology data. However, in New Zealand, particularly in Taranaki Basin, numerous exploration and production wells have been drilled, and the basins are well understood (King and Thrasher, 1996). Consequently, our understanding of potential petroleum system elements in northern Zealandia is informed by onshore geology, and especially that of Taranaki Basin.

Geochemically, oil from Taranaki Basin is typed to Late Cretaceous-Paleogene coaly source rocks (Sykes, 2001, Sykes and Snowdon, 2002). The source rock intervals in Taranaki include Seismic Unit U2a: the Late Cretaceous Rakopi Formation, Late Cretaceous North Cape Formation, Palaeocene Farewell Formation; and Seismic Unit U1b (Mangahewa Formation), Early Eocene Kaimiro Formation and Middle to Late Eocene Mangahewa Formation (Cook, 1987; S. Killops et al., 1998). The source rocks have type III kerogen coals with interbedded carbonaceous shales, which are also known to have high liptinite and a minor contribution of marginal marine material or bacterial modification (Killops et al., 1994; Sykes et al., 2004).

Reservoirs found in the Maui, Kapuni, Kupe, Pohokura, Mangahewa, and Tui fields are composed of Paleocene shoreline and Eocene coastal plain sandstones of the Farewell, Kaimiro, Mangahewa and McKee formations (King and Thrasher, 1996, GNS, 2015). Neogene Mount Messenger and Moki Formations are submarine fan sandstones but contain only small petroleum accumulations (King and Thrasher, 1996).

Seals formed during Cretaceous and Paleocene flooding when mudstones of the Turi Formation and micritic carbonate-rich rocks of the Tikorangi Formation were deposited (King and Thrasher, 1996).

Structural traps within Taranaki Basin include four-way dip, three-way dip and fault closures, drape folds, thrust controlled anticlines, and overthrusts (Nicol et al., 2004). These structural traps resulted from Neogene tectonic deformation. Older trapping structures may correspond to Cretaceous normal faulting, but Neogene reverse faulting 
and fault reactivation makes it difficult to divide the two stages of structural development (King and Thrasher, 1996).

\subsection{Source rocks}

Petroleum source rocks likely to be present within northern Zealandia are likely to be similar to those in adjacent better-known basins such as Taranaki Basin in New Zealand and Gippsland Basin in eastern Australia and it is plausible that there are similarities with Timor-Leste and PNG. Based on evidence from Australia, New Zealand, Timor-Leste, PNG, dredge samples, drilling in Taranaki Basin, seismic anomalies, and previous seismic interpretation (Burns and Andrews, 1973, Burns, 1973a, Burns, 1973b, Ingram et al., 1996, King, 2000b, King and Thrasher, 1996, Rouillard et al., 2015, Sutherland, 2019b, Sutherland et al., 2018b, King, 2000a), there are three general groups of sedimentary formations in northern Zealandia that represent potential petroleum source rocks. They are defined from oldest to youngest: Mesozoic Gondwana margin-marine, terrestrial, lacustrine, or marine sediments; Late Cretaceous Gondwana break-up coal measures and possibly any associated lacustrine or marine facies; and post-break-up Zealandia subsidence coal measures or marine rocks.

The oldest rocks with source potential in New Zealand occur within the Mesozoic Murihiku Supergroup. The Murihiku Group has traditionally been defined as economic basement in New Zealand, but is known to contain coaly source rocks (Mortimer, 2004, Mortimer et al., 2009, Cook et al., 1999). The proposed depositional environment was a large fore-arc basin near the Gondwana margin that extended from south of New Zealand to at least as far north as New Caledonia (Ballance, 1993). Waka Nui-1 in Northland Basin intersected Jurassic grey-red, veined, and mottled mudstone interbedded sandstone, siltstone, and coal (Milne and Quick, 1999, Mortimer et al., 2009). Vitrinite reflectance (VR) analysis of Jurassic coal was $0.7 \%$ (West, 1999), indicating it is immature and close to the top of the oil window at $3602 \mathrm{~m}$ bsf (Hegarty, 1999, Uruski et al., 2004). Middle Jurassic coals discovered in Waka Nui-1 are immature, and outcrop of Late Jurassic coals onshore indicate that the Jurassic succession (Murihiku Supergroup) may contain petroleum source potential (Campbell et al., 2003). Head-space gas and pore water chemistry results from U1508 suggest active petroleum migration at that site that is likely sourced from Murihiku coaly source rocks (Sutherland, 2019c). 
Australia Gondwana source rocks may extend throughout the region. It is plausible that a wide range of terrestrial, coastal and marine facies exist across northern Zealandia. Australia Gondwana source rocks are Jurassic Walloon Coal Measures and Koukandowie Formation of Clarence-Moreton Basin, "Jurassic Beds" of the Gippsland Basin (Holdgate and McNicol, 1992). Marine mixed carbonate and clastic sequences in Timor-Leste and Jurassic clay-rich marine source rocks of Imburu Formation in PNG may also have correlative in northern Zealandia (Cameron, 1907, Ingram et al., 1996, Whitehouse, 1955, Charlton, 2002, Ahmed A. S. et al., 1988, Brown et al., 1979, Volk et al., 2005).

Jurassic sediments with source potential are present in several basins around the Tasman Sea: in the Gippsland Basin (Holdgate and McNicol, 1992), the ClarenceMoreton and Surat in Queensland (O'Brien et al., 1994, Ingram et al., 1996, Shaw et al., 2001, Wells and O'Brien, 1994). The Walloon Coal Measures and Koukandowie Formation contain interbedded sandstone, siltstone, claystone and coal (Ingram et al., 1996, Khorasani, 1987). In Surat Basin, oil generation is from hydrogen-rich coals such as those of the Walloon Coal Measures, which hydrocarbons are expected to generate from subereous components and terpene resinites in low rank lignites and sub-bituminous coals (Khorasani, 1987). Further south in Australia, the oldest sediments in Gippsland Basin are the Late Jurassic and Early Cretaceous rift-related volcanoclastic Strzelecki Group underlain by the "Jurassic Beds" (Holdgate and McNicol, 1992, Norvick et al., 2001). The "Jurassic Beds" contains coal measures and lacustrine facies deposited during the early stages of the Early Otway Rift Phase (Norvick et al., 2001).

Timor-Leste and PNG contain Mesozoic marine source rocks. The main source rocks in Timor-Leste is likely Upper Triassic to Lower Jurassic restricted marine source rocks (Charlton, 2002, da Costa Monteiro, 2003). In onshore Timor-Leste, Mesozoic samples from the Triassic Niof Formation and Late Triassic Aitutu Formation comprise type II and type III kerogens that deposited in suboxic to anoxic clay-rich environment with some terrigenous input (da Costa Monteiro, 2003, Peters et al., 1999). Geochemically, source rocks in PNG have a mixture of marine and terrestrial organic matter deposited under mildly oxygenated conditions in an open marine to deltaic environment (Ahmed A. S. et al., 1988, Ahmed et al., 2012). The Papuan Basin contains mainly clay-rich, terrestrialinfluenced Jurassic marine source rocks deposited under oxic conditions (Ahmed et al., 
2012), and are comparable in organic facies and share many similarities with Upper Jurassic source rocks present on the North West Shelf of Australia (Volk et al., 2005).

Gondwana break-up started in the mid-Cretaceous ( 110-100 Ma) and persisted until full Zealandia separation was achieved by 85-80 Ma (Cluzel et al., 2010, Davy et al., 2008, Matthews et al., 2012, Uruski, 2008, Norvick et al., 2001). The mid-Cretaceous phase deposition of the Taniwha Formation (100-90 Ma) and the Golden Beach Group (98-80 Ma) (Norvick et al., 2001, King and Thrasher, 1996, Lowry and Longley, 1991, Uruski et al., 2003, King, 2000a). The middle Cretaceous Taniwha Formation contains possible coaly source rock in Taranaki Basin (Killops et al., 1994). The Taniwha Formation comprises siltstone, sandstone, coal, and carbonaceous shale and represents deposition in marginal marine to terrestrial environments (King \& Thrasher 1996). During the Late Cretaceous, fluvial-deltaic sediments are found in the region. The Golden Beach is a subdivision of the lower part of Gippsland Basin's Latrobe Group and is interpreted as an unconformity-bounded depositional system. It recorded the transition from rift system to continental margin deposition (Bernecker and Partridge, 2001). The Golden Beach represents marine and marginal marine environments in Santonian and Campanian times (Duff et al., 1991, Bernecker and Partridge, 2001). The Golden Beach rapidly subsiding rift (Bishop, 2000) was filled by deepwater lakes following break-up of the southern Australia margin and was then flooded by marine water (Duff and others, 1991; Partridge, 1996). The Golden Beach is divided into marine shale and minor sandstones of the Anemone Formation and fluvial-deltaic and paralic Chimaera Formation (Bernecker and Partridge, 2001).

Northern Zealandia and Gippsland Basin experienced thermal subsidence after rifting, resulting in transgression and deposition of Late Cretaceous and Paleogene petroleum source rocks (85-55 Ma) (Laird and Bradshaw, 2004, Cook et al., 1999, King and Thrasher, 1996). Cretaceous coal measures are found within the Pakawau Group in Taranaki Basin and Latrobe Group of Gippsland Basin. The Pakawau Group contains Late Cretaceous Rakopi Formation coal measures and North Cape Formation shallow marine lithofacies (Killops et al., 1994, King and Thrasher, 1996). Uruski \& Baillie (2004) interpreted that Rakopi Formation ended when rapid marine transgression inundated. Pakawau Group coals (Uruski et al., 2008) are thought to be a predominant source rock in Taranaki Basin (Killops et al., 1994). The Latrobe Group consists of Maastrichtian and Palaeogene sandstone, siltstone, mudstone, coal and volcanic rocks 
(Fielding, 1992). Deposition of sandstones, shales and coal were in the alluvial plain, coastal plain, shoreface and shelf depositional environments along wave-dominated shorelines (Bernecker et al., 2003, Rahmanian et al., 1990, Fielding, 1992).

Romney-1 was drilled in the deepwater part of Taranaki and reached total depth in Late Cretaceous Teratan aged sediment (91-87 Ma) (Rad, 2015). It intersected >33 m of brownish-black carbonaceous siltstone and claystone ( $\operatorname{Rad}, 2015)$. Total thickness of this carbonaceous unit was not determined because the well stopped before reaching its base. Romney-1 penetrated 657 m of Late Cretaceous (Haumurian) coal measures assigned to the Rakopi Formation (Rad, 2015). Uruski and Warburton (2010) speculated from seismic facies mapping that the region around Romney- 1 and Tane- 1 contains coaly source rocks of the Rakopi Formation.

Cretaceous coaly rocks have been dredged in northern Zealandia. Herzer et al. (1999) report coaly sediments with age 95 to $87 \mathrm{Ma}$ (late Cenomanian to late Coniacian) dredged from a seabed outcrop on the flank of West Norfolk Ridge. Another sample of mixed marine and terrestrial organic material dredged from Reinga Ridge had an age of 85 to $75 \mathrm{Ma}$ (Santonian to Campanian) (Herzer et al., 1999). They both have low TOC and maturity, but such samples indicate potential coaly source rocks are present in the south of the region (Uruski et al., 2008, Herzer et al., 1999, Browne et al., 2016).

Taranaki and Gippsland Basins were separated by Tasman Sea opening and both basins had similar environmental controls on the deposition of coaly source rocks (Uruski et al., 2003). Taranaki and Gippsland contain coal measures of Cretaceous and Paleogene ages. Taranaki has minor volumes generated from Palaeocene black marine shale. Similarly, Gippsland contains predominantly terrestrial coaly source rocks, but a marine signature is detected in oil from the southeastern part of the basin (Gorter, 2001).

Seismic mapping in the study area identified bright discontinuous reflectors within Seismic Unit U3 sections that may be coal measures (Fig. 3.9). Comparison to eastern Australia and New Zealand (e.g., near Waka Nui-1) suggests these may be older source rocks of the Queensland Jurassic potential source rock type I or Murihiku potential source rock type III. Type II marine source rocks of PNG and Timor-Leste may have correlatives in northern Zealandia, but there is no way to verify this with seismic interpretation. 
Based on similarities to Taranaki and Gippsland basins, it is likely many regions in northern Zealandia have potential coaly source rocks within Seismic Unit U2b (syn breakup), and at the base of Seismic Unit U2a (post break-up). Type II Late Cretaceous carbonaceous marine mudstone occurs in NCTS, based on samples and headspace gases collected at Site U1509 (Fig. 1.5) (Sutherland, 2019b).

\subsection{Reservoir rocks}

Reservoir rocks in Gippsland are Paleogene in age, but accumulations have also occurred in Late Cretaceous sediments (Uruski et al., 2003, Bishop, 2000). Reservoir rock in Taranaki is mainly Paleocene of the Kapuni Group, and there are also significant discoveries in fractured Oligocene limestone and Neogene turbidite fans (Uruski et al., 2003, King and Thrasher, 1996).

The primary reservoir of Gippsland Basin is Latrobe Group sandstones (McKerron et al., 1998, Thornton et al., 1980, Bishop, 2000). Reservoir distribution in the intraLatrobe sequence involves deltaic sandstones and fluvial and submarine channels. Porosity in the reservoir is reported to be 12 to $30 \%$, and permeability is locally above 1 Darcy (Kanen, 1993). Bishop (2000) reported that porosity decreased below $4 \mathrm{~km}$ depth.

The Rakopi Formation of Taranaki Basin comprises fluvial, marginal or shallow marine sandstones. Romney-1 penetrated ( 236 m) shallow marine facies, and ( 421 m) terrestrial facies of the Rakopi Formation (Rad, 2015, Schiøler et al., 2014). Petrological analysis (cores) showed that fluvial sandstones of Rakopi Formation had porosity up to $21.9 \%$ and permeability up to $64.3 \mathrm{mD}$ (milli Darcy). In Tane -1, the Rakopi Formation is $475 \mathrm{~m}$ of terrestrial facies, with about 60\% sandstone (Uruski and Warburton, 2010), based on geophysical wireline logs and cutting descriptions.

The North Cape Formation of Taranaki Basin contains a Late Cretaceous transgressive succession that is intersected in Romney-1, Tane-1, and Wainui-1. In Romney-1, North Cape Formation is dominated by shelfal, well-sorted fine sandstone ( $\operatorname{Rad}, 2015)$. Fine sandstone beds have porosity up to $24 \%$ and permeability up to 18 mD. Wainui-1 contains 113 m of North Cape Formation (SBPT, 1982); a lower sequence of $55 \mathrm{~m}$ of coastal plain coal measures, and an upper sequence of $58 \mathrm{~m}$ of shelfal marine 
facies. In Tane-1, the North Cape Formation contains terrestrial coal measures (a lower sequence at depth $3307 \mathrm{~m}$ below seafloor) and transgressive shoreface to shallow marine sandstone (an upper sequence at depth 2448-3009 m below seafloor) (SBPT, 1977, Collot et al., 2009). Transgressive marginal marine deposits have porosities of up to $25 \%$ and permeabilities up to $1000 \mathrm{mD}$ (SBPT, 1977).

Northland and Taranaki Basins experienced passive subsidence that led to burial of extensional horsts by Seismic Unit U2a (Bache et al., 2014a, Bache et al., 2012a). In Taranaki Basin, this is the transgressive terrestrial and marginal marine Kapuni Group, and the marine lateral equivalent is the Moa Group (King and Thrasher, 1996, Baur et al., 2014).

Seismic Units U2 and U1 contain potential reservoir rocks. Transgressive sandstones, as intersected in Tane-1 well, are present in Seismic Unit U2. Seismic Unit U2 is transgressive and onlaps basement highs across most of the Tasman Frontier region. Evidence for transgression is also found locally as clinoform sequences inferred to be of self-edge origin, e.g., U-FWAY-2b (Fig. 3.10) (Rouillard et al., 2015) or Aotea sequence (Baur et al., 2014). Some coastal sandstone facies have excellent reservoir properties (porosity $>20 \%$, permeability $>200 \mathrm{mD}$, eg., Maui and Pohukura producing fields in Taranaki, New Zealand) (GNS, 2015).

Seismic Unit U1 was primarily deposited in bathyal conditions, as confirmed by drilling, and contains deepwater fans and channel systems, and pelagic drape deposits that are variably affected by bottom-currents. Late Eocene contraction locally folded Seismic Unit $\mathrm{U} 2$ and regional uplift involved erosion of topographic highs, with deposition of the products of this erosion into Seismic Unit U1b. High amplitude seismic facies within U1b may represent reservoir sandstones (Bache et al., 2012a, Bache et al., 2012b).

Deepwater channel and turbidite fans have been documented throughout the Neogene succession near New Zealand (Seismic Unit U1) (Baur et al., 2014, King and Thrasher, 1996, Strogen et al., 2014, Uruski and Wood, 1991), and may exist across all of northern Zealandia (Herzer et al., 1997, Etienne et al., 2018, Sutherland, 2019b). Neogene channels and fans may contain sandstone with high porosity and permeability due to their shallow burial (Uruski and Warburton, 2010). However, by analogy with reservoirs in Taranaki, 
it is likely that reservoir rocks associated with Seismic Unit U1 are more restricted in extent and have poorer reservoir properties than those in Seismic Unit U2.

\subsection{Seals}

Cretaceous and Paleogene thermal subsidence resulted in deposition of the terrestrial and marginal marine Pakawau Group, Kapuni Group and the marine lateral equivalent called the Moa Group (King and Thrasher, 1996). The North Cape Formation of the Pakawau Group represents a Late Cretaceous transgressive sequence of dominantly marine sandstones. The Moa Group is dominated by fine-grained marine mudstone of the Turi Formation, including upper Eocene minor turbidite sandstone (Seismic Unit U1b) (King and Thrasher, 1996). The Turi Formation is a regional seal in Taranaki Basin. In Reinga and Northland Basins, Seismic Units U2 and U1b contain marine claystone, marl and limestones in the Waka Nui-1 well, and these units are correlated with the Turi Formation (Stagpoole et al., 2009). The Eocene succession contains bathyal claystone and siltstone and is calcareous (limestone in places) and found to be an effective seal, as identified in Romney-1 well (Rad, 2015). Formation pressure measurements in Romney1 revealed that sandstones in the North Cape Formation have pore pressure up to $280 \mathrm{psi}$ above hydrostatic pressure (at depth $3478.63 \mathrm{~m}$ ).

Regional correlation combined with site data offer compelling evidence for the presence of a seal. Seismic Unit U2 has fine-grained shelf and bathyal mud, which formed during marine transgression (Rollet et al., 2012, Bache et al., 2014a, King and Thrasher, 1996). The seal in the study area is fine-grained mudstone and micritic limestone.

For a fine-grained sediment to be an effective petroleum seal, it must have low porosity, and this depends upon its maximum depth of burial. Porosity data collected during IODP Expedition 371 showed that porosity decreased from $\sim 65 \%$ to $\sim 25 \%$ during the first $800 \mathrm{~m}$ of burial (Fig. 4.2) (Sutherland, 2019b). At Site U1509, surface porosity is $63 \%$ and $\mathrm{c}=1952 \pm 140 \mathrm{~m}$ (Sutherland, 2019b) and is similar to Taranaki mudstone $(\phi o=54 \%$ and $\mathrm{c}=2000 \mathrm{~m})$ (Funnell et al., 1996). This indicates that Cretaceous claystone in Seismic Unit U2a is not an effective petroleum seal until it is buried by at least $1 \mathrm{~km}$ of overburden. 


\subsection{Traps and migration}

Effective traps have been identified across southeast Australia and New Zealand (Auzende et al., 2000b, Bache et al., 2012a, Bache et al., 2013, Bache et al., 2012b, Bishop, 2000, Ingram et al., 1996).

Gippsland Basin experienced Eocene to Early Miocene compression resulting in anticlines and fault traps (Mebberson, 1989, Moore et al., 1992, Ozimic et al., 1987). Petroleum mostly accumulated below the Top Latrobe unconformity in anticlines eroded and then sealed by the overlying regional Seaspray Group (micritic limestone, similar to Seismic Unit 1 in the Tasman region), e.g. the Kingfish and Barracouta fields (Mebberson, 1989). Intra-Latrobe Group stratigraphic traps in the Barracouta Field formed at about 34 Ma (Early Oligocene) (Mebberson, 1989). Fault traps within the Golden Beach Group (Late Cretaceous) are formed by lacustrine sandstones juxtaposed against thick lacustrine shale sections by Paleogene faulting (Bishop, 2000).

In Gippsland Basin, generation and expulsion of oil and gas started in Late Cretaceous and Early Palaeocene time, due to higher heat-flow and subsidence of this area before the formation of trapping structures in Late Eocene to Early Miocene time (Moore and others, 1992; Keall and Smith, 1996). Petroleum generation that filled many fields is inferred to be sourced from younger (Late Cretaceous) Latrobe source intervals (Moore et al., 1992).

Mapping of Seismic Units U3 and U2b reveals unconformities, truncation, onlap relationship, and faults and subsequent compaction-drape that provide a range of trapping mechanisms (Fig. 3.9, 3.11, 3.12, 3.15, 3.22 \& 3.24). Eocene contraction created structural traps within Seismic Unit U2, particularly in the southern part of the region (Sutherland et al., 2017).

Multiple rifting phases created fault-related trapping styles, such as tilted fault blocks and drape over horsts within Seismic Unit U3 and the base of Seismic Unit U2b (Colwell et al., 2010b). Cenozoic tectonism may create a breach risk for trapped hydrocarbons within Seismic Units U2 and U3 (Rollet et al., 2012, Colwell et al., 2010b). 
Some Cretaceous horst blocks were eroded, forming stratigraphic and compactional anticline traps above them (Seismic Unit U2). Transgressive deposition provides the opportunity for stratigraphic trapping of hydrocarbons, and naturally places clay-rich seal rock over coastal and shelf reservoir sandstones. Anticline traps are mapped in Reinga Basin, where Seismic Unit U2a is deformed (Bache et al., 2012a), and isolated anticlines are observed across the southern Tasman Frontier from Gippsland to Reinga Basin (Sutherland et al., 2017).

In the north part of the study area, seismic mapping shows that Seismic Unit U2 is affected by diapiric deformation (Fig 3.10) (Auzende et al., 2000b, Bache et al., 2014b, Exon et al., 2007, Rouillard et al., 2015). The diapirs are abundant and form structural dips and faults that might focus petroleum migration and develop structural traps. The diapirs were probably triggered by Eocene compressional deformation (Auzende et al., 2000b), but require some (currently unknown) driving mechanism that may be provided by low-density salt or over-pressured claystone.

\subsection{Overburden deposition and source rock maturity}

Thermal maturity modelling (deepwater Taranaki Basin) (Fig. 5.1) (Uruski et al., 2003) predicts 3,200 m bsf for type III non-marine source rocks (Uruski et al., 2003, Sykes, 2001). The present-day gas window is estimated below 5,000 $\mathrm{m}$ bsf for type III source rocks (Uruski et al., 2003).

Source rock modelling predicted oil generation to start at $\sim 95^{\circ} \mathrm{C}$ corresponding to a burial of about 3,200 m below seafloor, based on thermal gradient of $3^{\circ} \mathrm{C} / 100 \mathrm{~m}$ (Sykes, 2001, Stagpoole et al., 2007). Romney-1 wireline logging measurement and bottom hole temperature of $116^{\circ} \mathrm{C}$ gives an observed thermal gradient of $3.5^{\circ} \mathrm{C} / 100(\operatorname{Rad}, 2015)$, and modifies the local predicted top of the oil window to $\sim 2,700 \mathrm{~m}$ bsf. Vitrinite reflectance (VR) analysis yields $\% \mathrm{Ro}=0.8$ at $2,950 \mathrm{~m}$ bsf, which confirms it is in the oil generation window (Rad, 2015). 


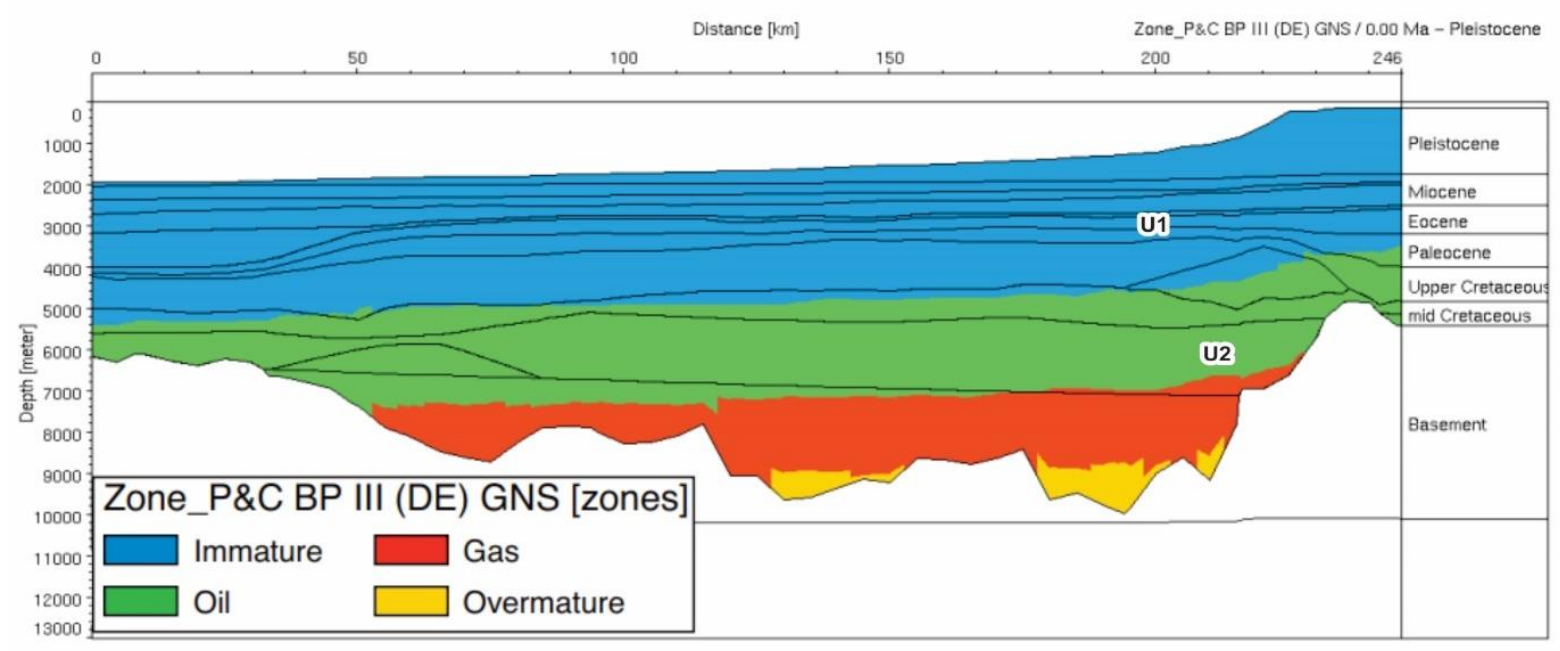

Figure 5.1 Cretaceous and Tertiary stratigraphy of deepwater Taranaki Basin and Present day maturity model (Pepper and Corvi, 1995, Uruski et al., 2003).

Wells in NCTS reveal a rapid increase in sedimentation rate during the Neogene (Sutherland, 2019b). The influx of sediments is prograding northwest with detritus from the Southern Alps and North Island shelf (King and Thrasher, 1996). This influx of sediment is overburden to bury Rakopi Formation to $\sim 2700 \mathrm{~m}$ below seafloor. Rapid sedimentation occurred in NCTS during the Neogene time due to the development of the plate boundary in New Zealand that resulted in rapid uplift and erosion. Neogene sedimentation rates reach about $1 \mathrm{~km}$ per million years and the overburden thickness is > $2 \mathrm{~km}$ over a large part of Taranaki Basin since $3 \mathrm{Ma}$.

On ridges (LHRN, LHRS) and away from Taranaki (REIN, NCTN), pelagic deposition since 4-2 Ma was characterised by lower mass accumulation rates values and colder ocean temperatures, suggesting thermal maturity at depth increased only slightly since then (Fig. 4.32). In the late Miocene and early Pliocene, burial by pelagic sediment rapidly occurred. During that time, the surface temperature was warmer, and hence the top boundary was affected by this temperature. Consequently, peak maturity of petroleum source rocks at greater depth probably developed in most places at the end of the Miocene to early Pliocene. 


\subsection{Distribution of petroleum system components}

The assessment of petroleum system components in northern Zealandia is reviewed and evaluated from existing and new seismic (TECTA and TAN1409 surveys) reflection interpretation tied to scientific boreholes and a small number of petroleum exploration boreholes near the coast of New Zealand (Bache et al., 2014a, Bache et al., 2012a, Bache et al., 2013, Burns, 1973a, Burns, 1973b, Burns and Andrews, 1973, Burns et al., 1973a, Burns et al., 1973b, King, 2000b, King and Thrasher, 1996, Norvick et al., 2001, Rouillard et al., 2014, Rouillard et al., 2015, Stagpoole et al., 2009, Stagpoole et al., 2007, Uruski and Baillie, 2002, Uruski et al., 2003, Uruski et al., 2008, Uruski et al., 2004, Uruski and Warburton, 2010, SBPT, 1981, SBPT, 1977, SBPT, 1982, SBPT, 1984, SBPT, 1986). Basins around New Zealand (King and Thrasher, 1996), Papua New Guinea (Brown et al., 1979) and Australia (Bishop, 2000, Ingram et al., 1996, O'Brien et al., 1994) with proven petroleum systems provide analogues across the region that may be applicable within the Tasman Frontier.

Based on regional and local stratigraphic correlation and seismic interpretation results, I infer that source rock, reservoir rock, seal rock, and suitable petroleum traps are present (Magoon and Dow, 1994, Allen and Allen, 2013) in northern Zealandia (Fig. 5.2) Romney-1 drilling in southern New Caledonia Trough (NCTS) (Collot et al., 2009) confirmed that all elements of a petroleum system and shows of petroleum were present (Fig. 5.2), but no significant petroleum accumulation was discovered at that location. 


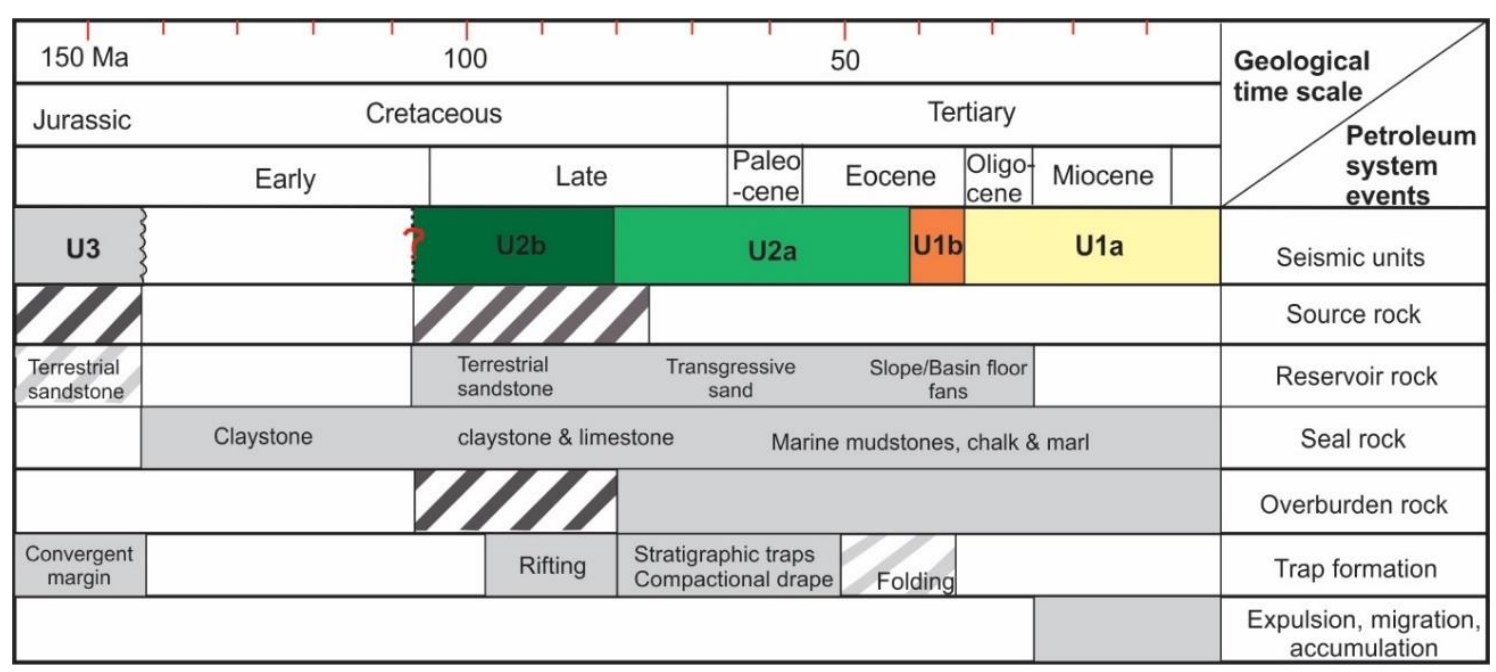

Figure 5.2 Petroleum system diagram for northern Zealandia showing the relative timing for key petroleum system elements. The grey colour represents the time at which elements occurred (Bache et al., 2014a, King and Thrasher, 1996, Sutherland, 2019b, Sutherland, 2019c).

There is considerable uncertainty introduced in the inference of source-reservoir-seal possibilities due to very limited sampling of Mesozoic rocks. Mesozoic coals of eastern Australia and New Zealand may extend throughout the region (Norvick et al., 2008b). Some of this coal is speculated to be oil-prone equivalent of the Jurassic Walloon Coal Measure of the Clarence-Mareton Basin (Powell et al., 1993, O'Brien et al., 1994). The Papuan Basin (PNG) is mainly clay-rich, terrestrial-influenced Jurassic marine source rocks. Further to the south-east, Triassic-Jurassic source rocks having both oil-prone and gas-prone observed in the onshore Timor-Leste (Robinson, 2012, Charlton, 2002), and Jurassic marine claystone (Elang and Plover Formations) and Lower Cretaceous (Darwin Formation) of Bonaparte Basin are oil-prone restricted. The distribution and nature of Seismic Unit U3 remains poorly known and all these correlatives are plausible.

Cretaceous carbonaceous mudstones and coals exist as the primary source rock in Gippsland (Alexander et al. 1987; Moore et al. 1992; Stainforth 1984) and Taranaki basins (King \& Thrasher 1996; Sykes et al. 2000). Late Cretaceous carbonaceous mudstone (oil-prone) in NCTS may be a marine equivalent in the southern New Caledonia Trough at Site U1509 (Sutherland, 2019b, Sutherland et al., 2018a).

Reservoir rocks may occur within pre-Cretaceous to Late Oligocene strata (Fig. 5.2). Jurassic and Late Cretaceous fluvial sandstone (Seismic Unit U3 and Seismic Unit U2), Late Cretaceous to Eocene transgressive (marginal or shallow marine) sandstones (Seismic Unit U2a) and Eocene to Late Oligocene slope/basin floor fans (Seismic Unit 
U1b) (Fig. 5.2) are all likely to be present. Transgressive sands are inferred in Seismic Unit U2 in FWAY and NCTS and equivalent facies have good reservoir properties in Taranaki and Gippsland basins (Rouillard et al., 2015, Baur et al., 2014, GNS, 2015). Deepwater basin-floor systems are not usually as good as coastal sands, but likely exist in Seismic Unit U1b.

Seal rocks are inferred to be Cretaceous claystone, or clayey micritic limestone associated with Seismic Unit U2a (Fig. 5.2). Chalk and marl within U1a are unlikely to be compacted enough to be an effective petroleum seal (Yang and Aplin, 2010). There is required a porosity $<30 \%$ to be a good seal, but porosity (Cretaceous claystone) observed at Site U1509 is about 50\% at a depth of $\sim 700 \mathrm{~m} \mathrm{bsf}$ (Fig. 4.2) (Sutherland, 2019b). There is required a minimum of 1-2 $\mathrm{km}$ of burial of Seismic Unit U2 clay/chalk before an effective petroleum seal is produced.

Structural traps include Late Cretaceous rifting of Seismic Unit U2b, Late Cretaceous to Paleocene stratigraphic traps and compactional drape, and Eocene folding (Seismic Unit U2a and Seismic Unit U1b) (Fig. 5.2). Eocene folding occurred in the Early to Late Eocene about 50-35 Ma (Bache et al., 2014a, King and Thrasher, 1996, Sutherland, 2019b, Sutherland, 2019c, Orr et al., 2020).

Mass accumulation rates (MAR) in the late Miocene and early Pliocene were high, as were climatic temperatures and hence peak thermal maturity, and hydrocarbon expulsion were likely at $\sim 3 \mathrm{Ma}$ (Fig. $4.32 \& 5.2$ ) across much of the region (everywhere except NCTS). In the late Miocene and early Pliocene, the surface temperature was warmer, and the top boundary was influenced by this temperature resulting in peak maturity of petroleum source rocks (at greater depth) at the end of Miocene to early Pliocene. The base of Seismic Unit U2 remains immature for petroleum generation over most of the region (Fig. 5.3). 


\subsection{Prospectivity}

The foundation of a petroleum system is to have a mature hydrocarbon-expelling source rock (Allen and Allen, 2013, Magoon and Dow, 1994). The maturity for oil or gas expulsion can be modelled in the Tasman Frontier, based on burial depth and assumptions of basal heat flow and surface temperature (e.g. Uruski et al., 2003). The isopach map for combined units U1-U2 shows that potential source rock maturity at the base of Seismic Unit U2 is limited to approximately one-fifth of the region. The base of Seismic Unit U2 at the present day is potentially generating petroleum in Fairway Basin (FWAY), southern New Caledonia Trough (NCTS), Reinga Basin (REIN) and adjacent to New Caledonia (NCTN) (Fig. 5.3). Hydrocarbon expulsion and maturity started in Neogene time (Fig. 5.3). In these regions, petroleum source rocks within the lower parts of Seismic Unit 2 may be viable components of a working petroleum system. Source rocks within Seismic Unit U3 may be mature in any region (base unconstrained), but the composition and distribution of Seismic Unit U3 remains very poorly known. 


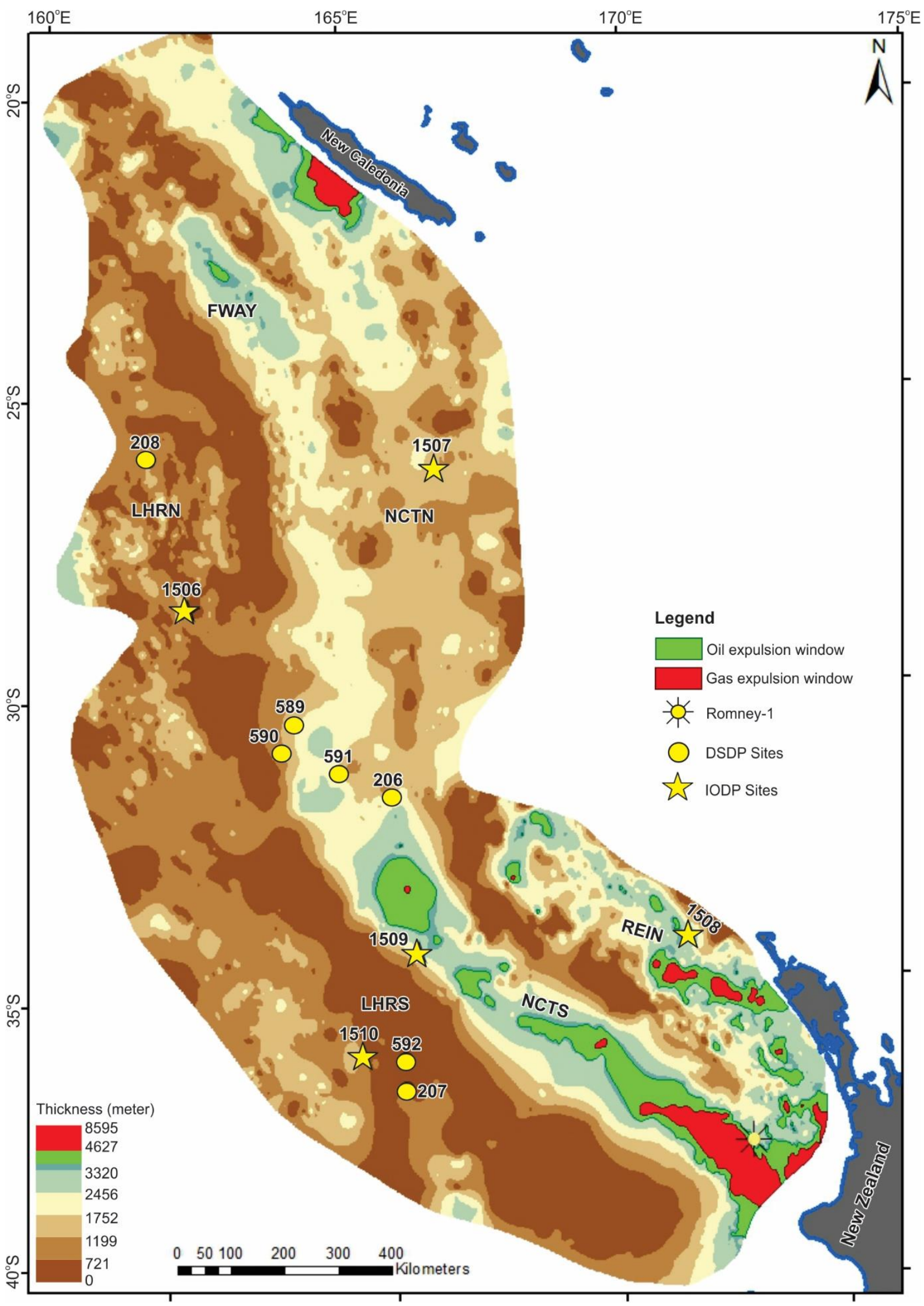

Figure 5.3 Map showing hydrocarbon generation window across northern Zealandia; top oil window is about $3500 \mathrm{~m}$ bsf and gas expulsion at about $5 \mathrm{~km}$ (Uruski et al., 2003). 
The coaly source rock of Rakopi Formation (Seismic Unit U2a) is confirmed to be within the oil-generation window at the Romney-1 well (Rad, 2015). Additionally, ethane and methane in head-space gases collected at Site U1509 (Sutherland, 2019b) provides evidence for thermogenic hydrocarbon generation near the axis of southern New Caledonia Trough (NCTS). Head-space gas and pore water chemistry results from Site U1508 (Sutherland, 2019c) indicate active petroleum migration in Reinga Basin (REIN), where this petroleum source may be Murihiku coaly rocks, as identified at Waka Nui-1 (Stagpoole et al., 2009), or Late Cretaceous coal/carbonaceous mudstone near the base of Seismic Unit U2.

In Summary, there are many play types that might exist. Sandstone-claystone in either Seismic Unit U3 or U2 provide plausible reservoir-seal combinations and there are many plausible trapping mechanisms related to either the RU1 or RU2 unconformities, normal faults, or folds, or stratigraphic pinch-out. Perhaps the key factors limiting future prospectivity are the unknown nature and thickness of Seismic Unit U3, and the limited maturity (burial) of Seismic Unit U2 (Fig. $5.2 \& 5.3$ ). 


\subsection{Future exploration prognosis}

Petroleum system elements and sediment thickness in the region allow general regions of prospectivity to be identified, with approximately one-fifth of the region predicted to have mature petroleum source rocks within the lower part of seismic Unit U2 (Late Cretaceous): FWAY, NCTS and REIN (Fig. 5.3) and adjacent to New Caledonia (NCTN). The rest of the region may still be prospective, but requires that the source rock be within Seismic Unit U3, which is mostly unsampled.

The southwest Pacific has attracted interest as a frontier location with possible significant petroleum potential and very large area (the study area of this thesis is the size of India). New Zealand and Australia are a favourable investment destination with market-based economy and secure regulatory settings and a stable political environment, but New Zealand has recently banned new petroleum exploration. About $25 \%$ of the study area is within the New Zealand EEZ.

I conclude that the region has considerable potential for further discoveries, and that the large size of the region makes it globally significant. Northern Zealandia needs more industry-standard seismic data to better understand the sedimentary strata, and there are no samples from deep strata in most of the region. Hence, it is plausible that a wide range of terrestrial, coastal and marine facies exist as found around New Zealand, Australia, PNG and Timor-Leste. Further data are needed to identify the distribution of source rocks, the quality of reservoir and seals, and assess heat flow variations across the region.

Future exploration in the large deepwater frontier between Australia, New Caledonia and New Zealand might best be focused in FWAY, NCTS and REIN. The target might be in Seismic Unit U2b (Fig. 5.2 \& 5.3). Seismic Unit U3 may be overmature locally but remains a high-risk but plausible target over much of the frontier area. 


\section{References}

ADAMS, C., BARLEY, M., MAAS, R. \& DOYLE, M. 2002. Provenance of PermianTriassic volcaniclastic sedimentary terranes in New Zealand: Evidence from their radiogenic isotope characteristics and detrital mineral age patterns. New Zealand Journal of Geology and Geophysics, 45, 221-242.

AHMED A. S., B. M. A., MOLDOWAN J.M., LEE C.Y. \& B.J, H. 1988. Regional Geochemical Prohect, Papua New Geuinea. 1.

AHMED, M., VOLK, H., ALLAN, T. \& HOLLAND, D. 2012. Origin of oils in the eastern Papuan basin, Papua New Guinea. Organic geochemistry, 53, 137-152.

AITCHISON, J., CLARKE, G., MEFFRE, S. \& CLUZEL, D. 1995. Eocene arc-continent collision in New Caledonia and implications for regional southwest Pacific tectonic evolution. Geology, 23, 161-164.

ALLEN, P. A. \& ALLEN, J. R. 2013. Basin analysis: Principles and application to petroleum play assessment, John Wiley \& Sons.

ATHY, L. F. 1930. Density, porosity, and compaction of sedimentary rocks. Aapg Bulletin, 14, 1-24.

AUDLEY-CHARLES, M. G. 1968. The geology of Portuguese Timor. Mem. Geol. Soc. Lond. 5, $76 \mathrm{pp}$.

AUZENDE, J.-M., BENETON, G., DICKENS, G., EXON, N., FRANÇOIS, C., HODWAY, D., JUFFROY, F., LAFOY, Y., LEROY, A. \& VAN DE BEUQUE, S. 2000a. Mise en évidence de diapirs mésozoiques sur la bordure orientale de la ride de Lord Howe (Sud-Ouest Pacifique): campagne ZoNeCo 5. Comptes Rendus de l'Académie des Sciences-Series IIA-Earth and Planetary Science, 330, 209215.

AUZENDE, J. M., VAN DE BEUQUE, S., DICKENS, G., FRANÇOIS, C., LAVOY, Y., VOUTAY, O. \& EXON, N. 2000b. Deep sea diapirs and bottom simulating reflector in Fairway Basin (SW Pacific). Marine Geophysical Researches, 21, 579-587.

BACHE, F., MORTIMER, N., SUTHERLAND, R., COLLOT, J., ROUILLARD, P., STAGPOOLE, V. \& NICOL, A. 2014a. Seismic stratigraphic record of transition from Mesozoic subduction to continental breakup in the Zealandia sector of eastern Gondwana. Gondwana Research, 26, 1060-1078.

BACHE, F., STAGPOOLE, V. \& SUTHERLAND, R. 2012a. Seismic stratigraphy of the Reinga Basin, NW New Zealand: tectonic and petroleum implications. Rosen, NC, Weimer, P., Coutes dos Anjos, SM., Henrickson, S., Marques, E., Mayall, M., Fillon, 221-22.

BACHE, F., STAGPOOLE, V. \& SUTHERLAND, R. The Reinga Basin, NW New Zealand: seismic stratigraphy, tectonic evolution and implications for hydrocarbon exploration. Advantage NZ: New Zealand Petroleum Conference, 2013.

BACHE, F., STAGPOOLE, V., SUTHERLAND, R., COLLOT, J., ROUILLARD, P., HACKNEY, R., ROLLET, N. \& HASHIMOTO, T. 2014b. Petroleum prospectivity of the Tasman frontier. The APPEA Journal, 54, 520-520.

BACHE, F., SUTHERLAND, R., STAGPOOLE, V., HERZER, R., COLLOT, J. \& ROUILLARD, P. 2012b. Stratigraphy of the southern Norfolk Ridge and the Reinga Basin: A record of initiation of Tonga-Kermadec-Northland subduction in the southwest Pacific. Earth and Planetary Science Letters, 321, 41-53. 
BALDWIN, S. L., RAWLING, T. \& FITZGERALD, P. G. 2007. Thermochronology of the New Caledonian high-pressure terrane: Implications for middle Tertiary plate boundary processes in the southwest Pacific. Special Papers-Geological Society of America, 419, 117.

BALLANCE, P. F. 1993. South Pacific sedimentary basins, Elsevier.

BALLANCE, P. F. \& CAMPBELL, J. D. 1993. The Murihiku arc-related basin of New Zealand (Triassic and Jurassic). Sedimentary basins of the world, 2, 21-33.

BAUR, J., SUTHERLAND, R. \& STERN, T. 2014. Anomalous passive subsidence of deep-water sedimentary basins: a prearc basin example, southern New Caledonia Trough and Taranaki Basin, New Zealand. Basin Research, 26, 242-268.

BELKIN, I. 1988. Main hydrological features of the central South Pacific. Ecosystems of the Subantarctic Zone of the Pacific Ocean, edited by ME Vinogradov and MV Flint, Nauka, Moscow, 21-28.

BELKIN, I. M. \& GORDON, A. L. 1996. Southern Ocean fronts from the Greenwich meridian to Tasmania. Journal of Geophysical Research: Oceans, 101, 36753696.

BERNECKER, T. \& PARTRIDGE, A. 2001. Emperor and Golden Beach subgroups: the onset of Late Cretaceous sedimentation in the Gippsland Basin, SE Australia.

BERNECKER, T., THOMAS, H. \& DRISCOLL, J. 2003. Hydrocarbon Prospectivity of Areas V03-1, V03-2, 03-1 (v) and 03-2 (v) Offshore Gippsland Basin, Victoria, Australia. VIMP Report, 79.

BISHOP, M. G. 2000. Petroleum system of the Gippsland Basin, Australia. US Department of the Interior, US Geological Survey.

BROOKS, D., GOODY, A., O'REILLY, J. \& MCCARTY, K. 1996. Bayu/Undan gascondensate discovery: western Timor Gap zone of cooperation, area A. The APPEA Journal, 36, 142-160.

BROWN, C., PIGRAM, C. \& SKWARKO, S. 1979. Mesozoic stratigraphy and geological history of Papua New Guinea. Palaeogeography, Palaeoclimatology, Palaeoecology, 29, 301-322.

BROWNE, G., LAWRENCE, M., MORTIMER, N., ClOWES, C., MORGANS, H., HOLLIS, C., BEU, A., BLACK, J., SUTHERLAND, R. \& BACHE, F. 2016. Stratigraphy of Reinga and Aotea basins, NW New Zealand: constraints from dredge samples on regional correlations and reservoir character. New Zealand Journal of Geology and Geophysics, 59, 396-415.

BUDILLON, G. \& RINTOUL, S. 2003. Fronts and upper ocean thermal variability south of New Zealand. Antarctic Science, 15, 141-152.

BURNS, R. 1973a. Regional aspects of deep sea drilling in the southwest Pacific. Init Repts DSDP, 21, 897-906.

BURNS, R. 1973b. Site 204: in BURNS, RE; ANDREWS, JE; et al. Initial Reports of the Deep Sea Drilling Project, 21, 33-56.

BURNS, R. \& ANDREWS, J. 1973. Initial reports of the deep sea drilling project, US Government Printing Office.

BURNS, R. E., ANDREWS, J. E., VAN DER LINGEN, G. J., CHURKIN JR, M., GALEHOUSE, J. S., PACKHAM, G. H., DAVIES, T. A., KENNETT, J. P., DIMITRICA, P., EDWARDS, A. R. \& VON HERZEN, R. P. 1973a. Site 206: Initital reports of the Deep Sea Drilling Project 21. Washington, D.C., U.S. Government Printing Office.

BURNS, R. E., ANDREWS, J. E., VAN DER LINGEN, G. J., CHURKIN JR, M., GALEHOUSE, J. S., PACKHAM, G. H., DAVIES, T. A., KENNETT, J. P., DIMITRICA, P., EDWARDS, A. R. \& VON HERZEN, R. P. 1973b. Site 207: Initial Reports of the Deep Sea Drilling Project 21.

CAMERON, W. 1907. The West Moreton Coalfields. Pubis geol. Surv. Qd, 204, 37. 
CAMPBELL, H.-J., GRANT-MACKIE, J.-A. \& PARIS, J.-P. 1985. Geology of the Moindou-Téremba area, New Caledonia. Stratigraphy and structure of Téremba Group (Permian-Lower Triassic) and Baie de St.-Vincent Group (Upper TriassicLower Triassic).

CAMPBELL, H., MORTIMER, N. \& TURNBULL, I. 2003. Murihiku Supergroup, New Zealand: redefined. Journal of the Royal Society of New Zealand, 33, 85-95.

CARTER, L., CARTER, R. \& MCCAVE, I. 2004. Evolution of the sedimentary system beneath the deep Pacific inflow off eastern New Zealand. Marine Geology, 205, 9-27.

CHARLTON, T. 2002. The petroleum potential of East Timor. The APPEA Journal, 42, 351-369.

CHEVILLON, C. 1996. Skeletal composition of modern lagoon sediments in New Caledonia: coral, a minor constituent. Coral Reefs, 15, 199-207.

CHISWELl, S. M., BOSTOCK, H. C., SUTTON, P. J. \& WILliAMS, M. J. 2015. Physical oceanography of the deep seas around New Zealand: a review. New Zealand Journal of Marine and Freshwater Research, 49, 286-317.

CLUZEL, D., ADAMS, C., MEFFRE, S., CAMPBELL, H. \& MAURIZOT, P. 2010. Discovery of Early Cretaceous rocks in New Caledonia: New geochemical and $\mathrm{U}-\mathrm{Pb}$ zircon age constraints on the transition from subduction to marginal breakup in the Southwest Pacific. The Journal of Geology, 118, 381-397.

CLUZEL, D., AITCHISON, J. C. \& PICARD, C. 2001. Tectonic accretion and underplating of mafic terranes in the Late Eocene intraoceanic fore-arc of New Caledonia (Southwest Pacific): geodynamic implications. Tectonophysics, 340, 23-59.

CLUZEL, D., MAURIZOT, P., COLLOT, J. \& SEVIN, B. 2012. An outline of the geology of New Caledonia; from Permian-Mesozoic Southeast Gondwanaland active margin to Cenozoic obduction and supergene evolution. EpisodesNewsmagazine of the InternationalUnion of Geological Sciences, 35, 72.

COLLOT, J., GELI, L., LAFOY, Y., VIALLY, R., CLUZEL, D., KLINGELHOEFER, F. \& NOUZÉ, H. 2008. Tectonic history of northern New Caledonia Basin from deep offshore seismic reflection: Relation to late Eocene obduction in New Caledonia, southwest Pacific. Tectonics, 27.

COLLOT, J., HERZER, R., LAFOY, Y. \& GELI, L. 2009. Mesozoic history of the Fairway-Aotea Basin: Implications for the early stages of Gondwana fragmentation. Geochemistry, Geophysics, Geosystems, 10.

COLLOT, J., SUTHERLAND, R., ROEST, W. R., PATRIAT, M, ETIENNE, S., JUAN, C., MARCAILlOU, B., SCHNURLE, P., BARKER, D., STRATFORD, W., WILLIAMS, S., WOLF, S, BORDENAVE, A. \& ROUSSEL, C. 2016. TECTA voyage report, RV L'Atalante. Rapport SGNC-2016(01), 85.

COLWELL, J., FOUCHER, J., LOGAN, G. \& BALUT, Y. 2006. Partie 2, Programme AUSFAIR (Australia-Fairway basin bathymetry and sampling survey) Cruise Report. Les rapports de campagnes à la mer, MD, 153.

COLWELL, J., HASHIMOTO, T., ROLLET, N., HIGGINS, K., BERNARDEL, G. \& MCGIVERON, S. 2010a. Interpretation of seismic data, Capel and Faust Basins, Australia's remote offshore eastern frontier. Geoscience Australia Record, 6.

COLWELL, J., HASHIMOTO, T., ROLLET, N., HIGGINS, K., BERNARDEL, G. \& MCGIVERON, S. 2010b. Interpretation of seismic data, Capel and Faust Basins, Australia's remote offshore eastern frontier. Geoscience Australia Record, 6, 58.

COOK, R., GREGG, R. \& BENNETT, D. 1999. New thinking on the petroleum prospectivity of deep Mesozoic sediments in New Zealand basins. The APPEA Journal, 39, 386-398. 
DA COSTA MONTEIRO, F. 2003. Late Triassic Strata from East Timor: Stratigraphy, Sedimentology, and Hydrocarbon Potential. University of Auckland.

DAMUTH, J. E., FlOOD, R. D., KOWSMANN, R. O., BELDERSON, R. H. \& GORINI, M. A. 1988. Anatomy and growth pattern of Amazon deep-sea fan as revealed by long-range side-scan sonar (GLORIA) and high-resolution seismic studies. AAPG Bulletin, 72, 885-911.

DAVY, B., HOERNLE, K. \& WERNER, R. 2008. Hikurangi Plateau: Crustal structure, rifted formation, and Gondwana subduction history. Geochemistry, Geophysics, Geosystems, 9.

DEACON, G. 1982. Physical and biological zonation in the Southern Ocean. Deep Sea Research Part A. Oceanographic Research Papers, 29, 1-15.

DICKENS, G. R. \& OWEN, R. M. 1996. Sediment geochemical evidence for an earlymiddle Gilbert (early Pliocene) productivity peak in the North Pacific Red Clay Province. Marine Micropaleontology, 27, 107-120.

DICKENS, G. R. \& OWEN, R. M. 1999. The latest Miocene-early Pliocene biogenic bloom: a revised Indian Ocean perspective. Marine Geology, 161, 75-91.

DUFF, B., GROILMAN, N., MASON, D., QUESTIAUX, J., ORMEROD, D. \& LAYS, P. 1991. Tectonostratigraphic evolution of the south-east Gippsland Basin. The APPEA Journal, 31, 116-130.

DURACK, P. J. \& WIJFFELS, S. E. 2010. Fifty-year trends in global ocean salinities and their relationship to broad-scale warming. Journal of Climate, 23, 4342-4362.

ETIENNE, S., COLlOT, J., SUTHERLAND, R., PATRIAT, M., BACHE, F., ROUILLARD, P., HENRYS, S., BARKER, D. \& JUAN, C. 2018. Deepwater sedimentation and Cenozoic deformation in the southern New Caledonia Trough (northern Zealandia, SW Pacific). Marine and Petroleum Geology, 92, 764-779.

EXON, N., LAFOY, Y., HILL, P., DICKENS, G. \& PECHER, I. 2007. Geology and petroleum potential of the Fairway Basin in the Tasman Sea. Australian Journal of Earth Sciences, 54, 629-645.

EXON, N., QUILTY, P., LAFOY, Y., CRAWFORD, A. \& AUZENDE, J. 2004. Miocene volcanic seamounts on northern Lord Howe Rise: lithology, age and origin. Australian Journal of Earth Sciences, 51, 291-300.

FARRELL, J. W., RAFFI, I., JANECEK, T. R., MURRAY, D. W., LEVITAN, M., DADEY, K. A., EMEIS, K.-C., LYLE, M., FLORES, J.-A. \& HOVAN11, S. 35. LATE NEOGENE SEDIMENTATION PATTERNS IN THE EASTERN EQUATORIAL PACIFIC OCEAN1. Proceedings of the ocean drilling program, scientific results, 1995. Ocean Drilling Program College Station, TX.

FIELDING, C. R. 1992. A review of Cretaceous coal-bearing sequences in Australia. Geological Society of America, Special Paper, 267, 303-324.

FLOOD, P. \& AITCHISON, J. 1992. Late devonian accretion of the Gamilaroi Terrane to eastern Gondwana: Provenance linkage suggested by the first appearance of Lachlan Fold Belt-derived quartzarenite. Australian Journal of Earth Sciences, 39, 539-544.

FUNNELL, R., CHAPMAN, D., ALLIS, R. \& ARMSTRONG, P. 1996. Thermal state of the Taranaki basin, New Zealand. Journal of Geophysical Research: Solid Earth, 101, 25197-25215.

GAINA, C., MÜLlER, D. R., ROYER, J. Y., STOCK, J., HARDEBECK, J. \& SYMONDS, P. 1998. The tectonic history of the Tasman Sea: a puzzle with 13 pieces. Journal of Geophysical Research: Solid Earth, 103, 12413-12433.

GANACHAUD, A., BOWEN, M., BRASSINGTON, G., CAI, W., CRAVATTE, S., DAVIS, R., GOURDEAU, L., HASEGAWA, T., HILL, K. \& HOLBROOK, N. 2013. Advances from the Southwest Pacific Ocean circulation and climate experiment (SPICE). CLIVAR Exchanges No. 61, 18, 16-23. 
GANACHAUD, A., CRAVATTE, S., MELET, A., SCHILlER, A., HOLBROOK, N., SLOYAN, B., WIDLANSKY, M., BOWEN, M., VERRON, J. \& WILES, P. 2014. The $S$ outhwest $P$ acific $O$ cean circulation and climate experiment (SPICE). Journal of Geophysical Research: Oceans, 119, 7660-7686.

GANACHAUD, A., KESSLER, W., WIJFFELS, S., RIDGWAY, K., CAI, W., HOLBROOK, N., BOWEN, M., SUTTON, P., QIU, B. \& TIMMERMAN, A. 2007a. Southwest Pacific Ocean Circulation and Climate Experiment (SPICE)part I. Scientific background.

GANACHAUD, A., KESSLER, W., WIJFFELS, S., RIDGWAY, K., CAI, W., HOLBROOK, N., BOWEN, M., SUTTON, P., QIU, F. \& TIMMERMANN, A. 2007b. Southwest Pacific Ocean Circulation and Climate Experiment (SPICE). Part I. Scientific Background. International CLIVAR Project Office, CLIVAR Publication Series number 111. NOAA OAR Special Report. NOAA OAR Special Report, 37.

GNS 2015. New Zealand Petroleum Basins. New Zealand Petroleum and Minerals.

GORTER, J. 2001. A Marine Source Rock in the Gippsland Basin?

GRANT, K. M. \& DICKENS, G. R. 2002. Coupled productivity and carbon isotope records in the southwest Pacific Ocean during the late Miocene-early Pliocene biogenic bloom. Palaeogeography, Palaeoclimatology, Palaeoecology, 187, 6182 .

HAIG, D. \& MCCARTAIN, E. 2007. Carbonate pelagites in the post-Gondwana succession (Cretaceous-Neogene) of East Timor. Australian Journal of Earth Sciences, 54, 875-897.

HAIG, D. W., MOSSADEGH, Z. K., PARKER, J. H. \& KEEP, M. 2019. Middle Eocene neritic limestone in the type locality of the volcanic Barique Formation, TimorLeste: Microfacies, age and tectonostratigraphic affinities. Journal of Asian Earth Sciences: $X, 1,100003$.

HAMILTON, L. 2006. Structure of the subtropical front in the Tasman Sea. Deep Sea Research Part I: Oceanographic Research Papers, 53, 1989-2009.

HASHIMOTO, T., HIGGINS, K., HACKNEY, R., STAGPOOLE, V., URUSKI, C., ROLLET, N., BERNARDEL, G., LOGAN, G. \& SUTHERLAND, R. 2009. Capel and Faust basins - integrated geoscientific assessment of Australia's remote offshore eastern frontier. The APPEA Journal, 49, 586-586.

HASHIMOTO, T., ROLLET, N., HIGGINS, K., BERNARDEL, G. \& HACKNEY, R. 2008. Capel and Faust Basins: Preliminary Assessment of and Offshore Deepwater Frontier Region.

HASHIMOTO, T., ROLlET, N., STAGPOOLE, V., HIGGINS, K., PETKOVIC, P., HACKNEY, R., FUNNELL, R., LOGAN, G., COLWELL, J. \& BERNARDEL, G. Geology and evolution of the Capel and Faust basins: petroleum prospectivity of the deepwater Tasman Sea frontier. 2010 New Zealand Petroleum Conference: conference proceedings: transformation. Wellington: Crown Minerals, Ministry of Economic Development.(Poster P24) p, 2010.

HASHIMOTO, T., SUTHERLAND, R., COLLOT, J., BACHE, F., STAGPOOLE, V., VISKOVIC, P., HIGGINS, K., ROUILLARD, P., ROLLET, N. \& FUNNELL, R. 2012. Petroleum Prospectivity of the Tasman Frontier Region: The Vast, Unexplored Frontier at Our Doorstep.

HAYES, D. E. \& RINGIS, J. 1973. Seafloor spreading in the Tasman Sea. Nature, 243, 454-458.

HEGARTY, K. 1999. Thermal history reconstruction in well X (Wakanui-1) using AFTA (apatite fission track analysis) ZFTA, VR and VRF. Geotrack report.

HENRIKSEN, E., BJØRNSETH, H., HALS, T., HEIDE, T., KIRYUKHINA, T., KLØVJAN, O., LARSSEN, G., RYSETH, A., RØNNING, K. \& SOLLID, K. 
2011. Uplift and erosion of the greater Barents Sea: impact on prospectivity and petroleum systems. Geological Society, London, Memoirs, 35, 271-281.

HERZER, R., DAVY, B., MORTIMER, N., QUILTY, P., CHAPRONIERE, G., JONES, C., CRAWFORD, A. \& HOLLIS, C. 2009. Seismic stratigraphy and structure of the Northland Plateau and the development of the Vening Meinesz transform margin, SW Pacific Ocean. Marine Geophysical Researches, 30, 21-60.

HERZER, R., SYKES, R., KILLOPS, S., FUNNELL, R., BURGGRAF, D., TOWNEND, J., RAINE, J. \& WILSON, G. 1999. Cretaceous carbonaceous rocks from the Norfolk Ridge system, Southwest Pacific: implications for regional petroleum potential. New Zealand Journal of Geology and Geophysics, 42, 57-73.

HERZER, R. H. 1995. Seismic stratigraphy of a buried volcanic arc, Northland, New Zealand and implications for Neogene subduction. Marine and petroleum geology, 12, 511-531.

HERZER, R. H., CHAPRONIERE, G., EDWARDS, A., HOLLIS, C., PELLETIER, B., RAINE, J., SCOTT, G., STAGPOOLE, V., STRONG, C. \& SYMONDS, P. 1997. Seismic stratigraphy and structural history of the Reinga Basin and its margins, southern Norfolk Ridge system. New Zealand Journal of Geology and Geophysics, 40, 425-451.

HERZER, R. H. \& MASCLE, J. 1996. Anatomy of a continent-backarc transform-the Vening Meinesz Fracture Zone northwest of New Zealand. Marine geophysical researches, 18, 401-427.

HIGGINS, K., HASHIMOTO, T., FRASER, G., ROLLET, N. \& COLWELL, J. 2011. Ion microprobe (SHRIMP) U-Pb dating of Upper Cretaceous volcanics from the northern Lord Howe Rise, Tasman Sea. Australian Journal of Earth Sciences, 58, 195-207.

HIGGINS, K., HASHIMOTO, T., ROLLET, N., COLWELL, J., HACKNEY, R. \& MILLIGAN, P. 2014. Structural analysis of extended Australian continental crust: Capel and Faust basins, Lord Howe Rise. The Geological Society of London, 933.

HIGGINS, K., HASHIMOTO, T., ROLLET, N., COLWELL, J., HACKNEY, R. \& MILLIGAN, P. 2015. Structural analysis of extended Australian continental crust: Capel and Faust basins, Lord Howe Rise. Geological Society, London, Special Publications, 413, 9-33.

HILL, K., RINTOUL, S., COLEMAN, R. \& RIDGWAY, K. 2008. Wind forced low frequency variability of the East Australia Current. Geophysical Research Letters, 35.

HOLDGATE, G. \& MCNICOL, M. 1992. New Directions-Old Ideas Hydrocarbon Prospects of the Strzelecki Group Onshore Gippsland Basin.

HORNIBROOK, N. D. B., EDWARDS, A., MILDENHALL, D., WEBB, P. \& WILSON, G. 1976. Major displacements in Northland, New Zealand; micropaleontology and stratigraphy of Waimamaku 1 and 2 wells. New Zealand journal of geology and geophysics, 19, 233-263.

HU, D., WU, L., CAI, W., GUPTA, A. S., GANACHAUD, A., QIU, B., GORDON, A. L., LIN, X., CHEN, Z. \& HU, S. 2015. Pacific western boundary currents and their roles in climate. Nature, 522, 299-308.

HUNT, T. 1978. Stokes magnetic anomaly system. New Zealand journal of geology and geophysics, 21, 595-606.

INGRAM, F., ROBINSON, V. \& FACER, R. A. 1996. Petroleum prospectivity of the Clarence-Moreton Basin in New South Wales, Department of Mineral Resources.

ISAAC, M. 1996. Geology of the Kaitaia area: Lower Hutt. New Zealand, Institute of Geological and Nuclear Sciences Ltd, 1. 
ISEE. n.d. Structure de la population et évolutions. https://www.isee.nc/population/recensement/structure-de-la-population-et-

evolutions [Online]. Available: https://www.isee.nc/population/recensement/structure-de-la-population-etevolutions [Accessed].

JULES, R., REN, Y. J. \& QIANG, C. 2015. Thermal History and Potential of Hydrocarbon Generated from Jurassic to Early Cretaceous Source Rocks in the Malita Graben, Northern Bonaparte Basin, Australia. International Journal of Geosciences, 6, 894.

KANEN, R. 1993. The offshore Gippsland Basin, Victoria. Mineral Services (Wantirna, Victoria, Australia), 101.

KARIG, D. E. 1971. Origin and development of marginal basins in the western Pacific. Journal of geophysical research, 76, 2542-2561.

KENNETT, J., CC, V. D. B., BAKER, P., BARTON, C., BOERSMA, A., CAULET, J., DUDLEY, W., GARDNER, J., JENKINS, D., LOHMAN, W. \& OTHERS 1986a. Site 590: Lord Howe Rise; 31 degrees S: Initial Reports of the Deep Sea Drilling Project 90.

KENNETT, J., CC, V. D. B., BAKER, P., BARTON, C., BOERSMA, A., CAULET, J., WCJ, D., GARDNER, J., JENKINS, D., LOHMAN, W. \& OTHERS 1986b. Site 592; Lord Howe Rise; 36 degrees S: Initial Reports of the Deep Sea Drilling Project 90. College Station, TX, United States: Texas A \& M University, Ocean Drilling Program.

KENNETT, J. \& VON DER BORCH, C. 1986. Southwest Pacific Cenozoic paleoceanography: Initial Reports of the Deep Sea Drilling Project, v. 90.

KENNETT, J., VON DER BORCH, C., BAKER, P., BARTON, C., BOERSMA, A., CAULER, J., DUDLEY JR, W., GARDNER, J., JENKINS, D. \& LOHMAN, W. 1985. Palaeotectonic implications of increased late Eocene-early Oligocene volcanism from South Pacific DSDP sites. Nature, 316, 507.

KENNETT, J., VON DER BORCH, C., BAKER, P., BARTON, C., BOERSMA, A., CAULET, J., DUDLEY, W., GARDNER, J., JENKINS, D., LOHMAN, W. \& OTHERS 1986c. Site 588; Lord Howe Rise; 26 degrees S: Initial Reports of the Deep Sea Drilling Project 90. College Station, TX, USA: Texas A \& M University, Ocean Drilling Program.

KENNETT, J., VON DER BORCH, C., BAKER, P., BARTON, C., BOERSMA, A., CAULET, J., DUDLEY, W., GARDNER JV, JENKINS, D., LOHMAN, W. \& OTHERS 1986d. Site 589; LordHowe Rise; 31 degrees S: Initial Reports of the Deep SeaDrilling Project 90 . .

KENNETT, J., VON DER BORCH, C., BAKER, P., BARTON, C., BOERSMA, A., CAULET, J., DUDLEY, W., GARDNER JV, JENKINS, D., LOHMAN, W. \& OTHERS 1986e. Site 591; Lord Howe Rise; 31 degrees S: Initial Reports of the Deep Sea Drilling Project 90. College Station, TX, United States: Texas A \& M University, Ocean Drilling Program.

KENNETT, J. P. 1977. Cenozoic evolution of Antarctic glaciation, the circum-Antarctic Ocean, and their impact on global paleoceanography. Journal of geophysical research, 82, 3843-3860.

KENNETT, J. P., HOUTZ, R. E., ANDREWS, P. B., EDWARDS, A. R., GOSTIN, V. A., HAJÓS, M., HAMPTON, M., JENKINS, D. G., MARGOLIS, S. V. \& OVENSHINE, A. T. 1975. Cenozoic paleoceanography in the southwest Pacific Ocean, Antarctic glaciation, and the development of the Circum-Antarctic Current. Initial reports of the deep sea drilling project, 29, 1155-1169.

KHORASANI, G. K. 1987. Oil-prone coals of the Walloon coal measures, Surat Basin, Australia. Geological Society, London, Special Publications, 32, 303-310. 
KILlOPS, S. D., WOOLHOUSE, A. D., WESTON, R. J. \& COOK, R. A. 1994. A geochemical appraisal of oil generation in the Taranaki Basin, New Zealand. AAPG bulletin, 78, 1560-1585.

KING, P. New Zealand's changing configuration in the last 100 million years: plate tectonics, basin development, and depositional setting. 2000 New Zealand Petroleum Conference Proceedings, 2000a. Crown Minerals, Ministry of Commerce Wellington, New Zealand.

KING, P. R. 2000b. Tectonic reconstructions of New Zealand: 40 Ma to the present. New Zealand Journal of Geology and Geophysics, 43, 611-638.

KING, P. R. \& THRASHER, G. P. 1996. Cretaceous Cenozoic geology and petroleum systems of the Taranaki Basin, New Zealand, Institute of Geological \& Nuclear Sciences.

KLINGELHOEFER, F., LAFOY, Y., COLLOT, J., COSQUER, E., GÉLI, L., NOUZÉ, H. \& VIALLY, R. 2007. Crustal structure of the basin and ridge system west of New Caledonia (southwest Pacific) from wide-angle and reflection seismic data. Journal of Geophysical Research: Solid Earth, 112.

LAFOY, Y., BRODIEN, I., VIALLY, R. \& EXON, N. 2005. Structure of the basin and ridge system west of New Caledonia (Southwest Pacific): a synthesis. Marine Geophysical Researches, 26, 37-50.

LAFOY, Y., PELLETIER, B., AUZENDE, J.-M., MISSÈGUE, F. \& MOLLARD, L. 1994. Tectonique compressive cénozoïque sur les rides de Fairway et Lord Howe, entre Nouvelle-Calédonie et Australie. Comptes Rendus de l'Académie des Sciences de Paris. Série 2a: Sciences de la Terre et des Planètes, 319, 1063-1069.

LAFOY, Y., VAN DE BEUQUE, S., BERNARDEL, G., MISSEGUE, F., NERCESSIAN, A., AUZENDE, J., SYMONDS, P. \& EXON, N. 1998. Scientists study deep geological structure between New Hebrides arc and eastern Australian margin. Eos, Transactions American Geophysical Union, 79, 613-614.

LAIRD, M. \& BRADSHAW, J. 2004. The break-up of a long-term relationship: the Cretaceous separation of New Zealand from Gondwana. Gondwana Research, 7, 273-286.

LEDLOW, L. B., GILBERT, W. W., OMSBERG, N. P., MENCER, G. J. \& JAMIESON, D. P. Revised Big-Bore Well Design Recovers Original Bayu Undan Production Targets. SPE Annual Technical Conference and Exhibition, 2008. Society of Petroleum Engineers.

LOUBRIEU, B., ROEST, W. \& PARTY, S. 2004. Rapport de mission de la campagne Noucaplac-2 de sismique lourde à bord du N/O L'Atalante-Programme EXTRAPLAC. Ifremer, Plouzane, France.

LOWRY, D. \& LONGLEY, I. 1991. A new model for the mid-Cretaceous structural history of the northern Gippsland Basin. The APPEA Journal, 31, 143-153.

LUM, T. \& VAUGHN, B. 2007. The Southwest Pacific: US interests and China's growing influence. China-US Economic and Geopolitical Relations, 85.

MAGOON, L. B. \& DOW, W. G. 1994. The petroleum system: chapter 1: Part I. Introduction.

MATTHEWS, K. J., SETON, M. \& MÜLLER, R. D. 2012. A global-scale plate reorganization event at 105- $100 \mathrm{Ma}$. Earth and Planetary Science Letters, 355, 283-298.

MAURIZOT, P. \& VENDÉ-LECLERC, M. 2009. Geological map of New Caledonia at 1/500 000. DIMENC, BRGM.

MCBEATH, D. 1977. Gas-condensate fields of the Taranaki basin, New Zealand. New Zealand journal of geology and geophysics, 20, 99-127. 
MCKERRON, A., DUNN, V., FISH, R., MILLS, C. \& VAN DER LINDEN-DHONT, S. 1998. Bass Strait's Bream B reservoir development: success through a multifunctional team approach. The APPEA Journal, 38, 13-35.

MEBBERSON, A. 1989. The future for exploration in the Gippsland Basin. The APPEA Journal, 29, 430-439.

MEDIANSKY, F. 1987. The security outlook in the southwest Pacific. The Australian Quarterly, 59, 266-277.

MEHIN, K. \& BOCK, M. 1998. Cretaceous source rocks of the onshore Gippsland Basin, Victoria, Department of Natural Resources and Environment.

MICKELSON, M., DANN, P. \& CULLEN, J. 1991. Sea temperature in Bass Strait and breeding success of the little penguin Eudyptula minor at Phillip Island, southeastern Australia. Emu, 91, 355-368.

MILNE, A. \& QUICK, R. 1999. Wakanui-1 well completion report PEP 38602. Ministry of Commerce, Wellington.

MITCHUM JR, R., VAIL, P. \& THOMPSON III, S. 1977a. Seismic stratigraphy and global changes of sea level: Part 2. The depositional sequence as a basic unit for stratigraphic analysis: Section 2. Application of seismic reflection configuration to stratigraphic interpretation.

MITCHUM JR, R. M., VAIL, P. R. \& SANGREE, J. B. 1977b. Seismic stratigraphy and global changes of sea level: Part 6. Stratigraphic interpretation of seismic reflection patterns in depositional sequences: Section 2. Application of seismic reflection configuration to stratigraphic interpretation.

MOORE, E. \& SMITH, J. 1995. Climatic change and migration from Oceania: implications for Australia, New Zealand and the United States of America. Population and Environment, 17, 105-122.

MOORE, P., BURNS, B., EMMETT, J. \& GUTHRIE, D. 1992. Integrated source, maturation and migration analysis, Gippsland Basin, Australia. The APPEA Journal, 32, 313-324.

MORRIS, M., STANTON, B. \& NEIL, H. 2001. Subantarctic oceanography around New Zealand: preliminary results from an ongoing survey. New Zealand Journal of Marine and Freshwater Research, 35, 499-519.

MORTIMER, N. 2004. New Zealand's geological foundations. Gondwana Research, 7, 261-272.

MORTIMER, N., CAMPBELL, H. J., TULLOCH, A. J., KING, P. R., STAGPOOLE, V. M., WOOD, R. A., RATTENBURY, M. S., SUTHERLAND, R., ADAMS, C. J. \& COLLOT, J. 2017. Zealandia: Earth's hidden continent. GSA Today, 27, 27-35.

MORTIMER, N., GANS, P. B., PALIN, J. M., HERZER, R. H., PELLETIER, B. \& MONZIER, M. 2014. Eocene and Oligocene basins and ridges of the Coral SeaNew Caledonia region: Tectonic link between Melanesia, Fiji, and Zealandia. Tectonics, 33, 1386-1407.

MORTIMER, N., HERZER, R., GANS, P., LAPORTE-MAGONI, C., CALVERT, A. \& BOSCH, D. 2007. Oligocene-Miocene tectonic evolution of the South Fiji Basin and Northland Plateau, SW Pacific Ocean: Evidence from petrology and dating of dredged rocks. Marine Geology, 237, 1-24.

MORTIMER, N., HERZER, R., GANS, P., PARKINSON, D. \& SEWARD, D. 1998. Basement geology from Three Kings Ridge to West Norfolk Ridge, southwest Pacific Ocean: evidence from petrology, geochemistry and isotopic dating of dredge samples. Marine Geology, 148, 135-162.

MORTIMER, N., RAINE, J. \& COOK, R. 2009. Correlation of basement rocks from Waka Nui-1 and Awhitu-1, and the Jurassic regional geology of Zealandia. New Zealand journal of geology and geophysics, 52, 1-10. 
MORTIMER, N., TULLOCH, A., SPARK, R., WALKER, N., LADLEY, E., ALLIBONE, A. \& KIMBROUGH, D. 1999. Overview of the Median Batholith, New Zealand: a new interpretation of the geology of the Median Tectonic Zone and adjacent rocks. Journal of African earth sciences, 29, 257-268.

MORY, A. J. 1991. Geology of the offshore Bonaparte Basin, northwestern Australia, Geological Survey of Western Australia.

MULHEARN, P. 1987. The Tasman Front: a study using satellite infrared imagery. Journal of Physical Oceanography, 17, 1148-1155.

NASH, J. 2013. Insular Toponymies: Place-naming on Norfolk Island, South Pacific and Dudley Peninsula, Kangaroo Island, John Benjamins Publishing.

NICOL, A., STAGPOOLE, V. \& MASLEN, G. Structure and petroleum potential of the Taranaki fault play. New Zealand Petroleum Conference Proceedings, 2004. 710.

NORVICK, M., LANGFORD, R., HASHIMOTO, T., ROLLET, N., HIGGINS, K. \& MORSE, M. 2008a. New insights into the evolution of the Lord Howe Rise (Capel and Faust basins), offshore eastern Australia, from terrane and geophysical data analysis.

NORVICK, M., SMITH, M. \& POWER, M. 2001. The plate tectonic evolution of eastern Australasia guided by the stratigraphy of the Gippsland Basin.

NORVICK, M. S., LANGFORD, R. P., HASHIMOTO, T., ROLLET, N., HIGGINS, K. L. \& MORSE, M. P. 2008b. New insights into the evolution of the Lord Howe Rise (Capel and Faust basins), offshore eastern Australia, from terrane and geophysical data analysis. In Blevin, J.E., Bradshaw, B.E. and Uruski, C (Eds), Eastern Australasian Basins Symposium III: Energy security for the 21 st century.

O'BRIEN, P. E., POWELL, T. G. \& WELLS, A. T. 1994. Petroleum potential of the Clarence-Moreton Basin. In: Wells, A. T. and O'Brien, P.E. (Eds), Geology and petroleum potential of the Clarence-Moreton Basin, New South Wales and Queensland, Australian Geological Survey Organisation Bulletin 241, Canberra, 277-290.

OKE, P. R. \& MIDDLETON, J. H. 2001. Nutrient enrichment off Port Stephens: the role of the East Australian Current. Continental Shelf Research, 21, 587-606.

ORR, D., SUTHERLAND, R. \& STRATFORD, W. 2020. Eocene to Miocene subduction initiation recorded in stratigraphy of Reinga Basin, northwest New Zealand. Tectonics, e2019TC005899.

ORSI, A. H., WHITWORTH III, T. \& NOWLIN JR, W. D. 1995. On the meridional extent and fronts of the Antarctic Circumpolar Current. Deep Sea Research Part I: Oceanographic Research Papers, 42, 641-673.

OWEN, A. D. \& LATTIMORE, J. 1998. Oil and gas in Papua new guinea. Energy policy, 26, 655-660.

OZIMIC, S., NICHOLAS, E., PAIN, L. \& VUCKOVIC, V. 1987. Australian Petroleum Accumulations, Gippsland Basin, Victoria. Department of Primary Industries and Energy, Bureau of Mineral Resources, Geology and Geophysics, Canberra, 252.

PEPPER, A. S. \& CORVI, P. J. 1995. Simple kinetic models of petroleum formation. Part I: oil and gas generation from kerogen. Marine and petroleum geology, 12, 291319.

PETERS, K. E., FRASER, T. H., AMRIS, W., RUSTANTO, B. \& HERMANTO, E. 1999. Geochemistry of crude oils from eastern Indonesia. AAPG bulletin, 83, 1927-1942.

PETERSON, L., MURRAY, D., EHRMANN, W. \& HEMPEL, P. 1992. Cenozoic carbonate accumulation and compensation depth changes in the Indian Ocean. Synthesis of results from scientific drilling in the Indian Ocean, 70, 311-333. 
POESTMA, G., FORTUINT, I. \& WAMEL, W. 2009. Basin-fill patterns controlled by tectonics and climate: the Neogene 'fore-arc'basins of eastern Crete as a case history. Tectonic controls and signatures in sedimentary successions, 40, 335.

POWELL, T. G., O'BRIEN, P. E. \& WELLS, A. T. 1993. Petroleum prospectivity of the Clarence-Moreton Basin, eastern Australia: A geochemical perspective. Australian Journal of Earth Sciences 40 (1), 31-44.

PRZESLAWSKI, R., WILLIAMS, A., NICHOL, S. L., HUGHES, M. G., ANDERSON, T. J. \& ALTHAUS, F. 2011. Biogeography of the Lord Howe rise region, Tasman sea. Deep Sea Research Part II: Topical Studies in Oceanography, 58, 959-969.

RAD, F. 2015. PEP 38451 Romney-1 well completion report. New Zealand Unpublished Openfile Petroleum Report, PR4951.

RAHMANIAN, V., MOORE, P., MUDGE, W. \& SPRING, D. 1990. Sequence stratigraphy and the habitat of hydrocarbons, Gippsland Basin, Australia. Geological Society, London, Special Publications, 50, 525-544.

RAINE, J. I., BEU, A. G., BOYES, A., CAMPBELL, H. J., COOPER, R. A., CRAMPTON, J. S., CRUNDWELL, M. P., HOLLIS, C. J. \& MORGANS, H. 2012. Revised calibration of the New Zealand geological timescale: NZGT2015/1. GNS Science report, 39, 1-53.

RAVENNE, C., DE BROIN, C., DUPONT, J., LAPOUILLE, A. \& LAUNAY, J. 1977. New Caledonia basin-Fairway Ridge: structural and sedimentary study.

REA, D. \& SNOECKX, H. Sediment fluxes in the Gulf of Alaska: Paleoceanographic record from site 887 on the Patton-Murray seamount platform. Proceedings of the Ocean Drilling Program. Scientific results, 1995. 247-256.

RICKWOOD, F. Towards development - the long history of petroleum exploration in Papua New Guinea. 1990. Papua New Guinea (PNG) Petroleum Convention Proceedings.

RINTOUL, S., HUGHES, C. \& OLBERS, D. 2001. The Antarctic circumpolar current system. In: Ocean Circulation and Climate/G. Siedler, J. Church and J. Gould, eds. New York: Academic Press. p.

ROBINSON, P. 2012. Exploration Opportunities in the Timor Sea Region.

ROLLET, N., MCGIVERON, S., HASHIMOTO, T., HACKNEY, R., PETKOVIC, P., HIGGINS, K., GROSJEAN, E. \& LOGAN, G. A. 2012. Seafloor features and fluid migration in the Capel and Faust basins, offshore eastern Australia. Marine and petroleum geology, 35, 269-291.

ROUILLARD, P., COLLOT, J., BACHE, F., SUTHERLAND, R., KROEGER, K. \& FUNNELL, R. 2014. Petroleum implications of stacked deltas in the Fairway Basin, offshore New Caledonia, Northern Tasman Frontier. The APPEA Journal, 54, 537-537.

ROUILlARD, P., COLlOT, J., BACHE, F., SUTHERLAND, R., KROEGER, K. F., FUNNELL, R., PATRIAT, M., ETIENNE, S. \& STAGPOOLE, V. Seismic Stratigraphy of the Fairway Basin, Northern Zealandia, Southwest Pacific: Geodynamic and Petroleum Implications. International Conference \& Exhibition, 2015.

ROUIllard, P., COLlOT, J., SUTHERLAND, R., BACHE, F., PATRIAT, M., ETIENNE, S. \& MAURIZOT, P. 2017. Seismic stratigraphy and paleogeographic evolution of Fairway Basin, Northern Zealandia, Southwest Pacific: from Cretaceous Gondwana breakup to Cenozoic Tonga-Kermadec subduction. Basin Research, 29, 189-212.

SBPT 1977. Well Resume Tane-1 (Offsore). Ministry of Economic Development New Zealand Unpublished Petroleum Reports, PR698, 264.

SBPT 1982. Well Resume, Wainui. Taranaki offshore. PPL 38049. Ministry of Economic Development New Zealand Unpublished Petroleum Reports, PR869, 278. 
SBPT 1984. Completion Report. Ariki-1. PPL38048. Ministry of Economic Development New Zealand Unpublished Petroleum Reports, PR1038, 179.

SBPT 1986. Well resume Te Ranga-1, PPL 38107

Taranaki New Plymouth. Ministry of Economic Development New Zealand unpublished petroleum report PR1197.

SBPT 1981. Well resume, Wainui-1, PPL 38049

Open-file Petroleum Report 869. Ministry of Commerce, Wellington.

SCHELLART, W., LISTER, G. \& TOY, V. 2006. A Late Cretaceous and Cenozoic reconstruction of the Southwest Pacific region: tectonics controlled by subduction and slab rollback processes. Earth-Science Reviews, 76, 191-233.

SCHIØLER, P., POWELL, S. \& REXILIUS, J. 2014. PEP 38451 biostratigraphy of Romney-1 well (2370-4618 m) Deepwater Taranaki, New Zealand. New Zealand Unpublished Openfile Petroleum Report, PR4951.

SHAW, R., ALDER, J. \& AADIL, N. 2001. The Offshore Clarence-Moreton Basin in New South Wales-A New Petroleum Play?

SHAW, W. 1983. Tropical cyclones: determinants of pattern and structure in New Zealand's indigenous forests. Pacific science, 37, 405-414.

SHOR JR, G., KIRK, H. \& MENARD, H. 1971. Crustal structure of the Melanesian area. Journal of Geophysical Research, 76, 2562-2586.

SKINNER, C. 2008. Assessment of Oil and Gas Reserves Discovered within the Taranaki Basin 1955-2000, and Potential Undiscovered Reserves.

SMITH, R. O., VENNELL, R., BOSTOCK, H. C. \& WILLIAMS, M. J. 2013. Interaction of the subtropical front with topography around southern New Zealand. Deep Sea Research Part I: Oceanographic Research Papers, 76, 13-26.

SOKOLOV, S. \& RINTOUL, S. R. 2009. Circumpolar structure and distribution of the Antarctic Circumpolar Current fronts: 1. Mean circumpolar paths. Journal of Geophysical Research: Oceans, 114.

SOKOLOV, S., RINTOUL, S. R. \& WIENECKE, B. 2006. Tracking the Polar Front south of New Zealand using penguin dive data. Deep Sea Research Part I: Oceanographic Research Papers, 53, 591-607.

STAGG, H., ALCOCK, M., BORISSOVA, I. \& MOORE, A. 2002. Geological framework of the southern Lord Howe Rise and adjacent areas. Geoscience Australia Record, 25, 151.

STAGPOOLE, V., BROWNE, G., ILG, B., HERZER, R., REID, E., BLAND, K., GRIFFIN, A. \& URUSKI, C. 2009. Petroleum prospectivity of the Reinga Basin. New Zealand Unpublished Openfile Petroleum Report, PR4037.

STAGPOOLE, V., FUNNELL, R., SCADDEN, P. \& MILNER, M. 2007. a, Basin Modelling of PEP 38451, Deepwater Taranaki, New Zealand. GNS Science Consultancy Report, 167.

STAGPOOLE, V.\& NICOL, A. 2008. Regional structure and kinematic history of a large subduction back thrust: Taranaki Fault, New Zealand. Journal of Geophysical Research: Solid Earth, 113.

STANDARD, J. C. 1961. Submarine geology of the Tasman Sea. Geological Society of America Bulletin, 72, 1777-1788.

STANTON, B. \& RIDGWAY, N. 1988. An oceanographic survey of the subtropical convergence zone in the Tasman Sea. New Zealand journal of marine and freshwater research, 22, 583-593.

STEINBERGER, B., SUTHERLAND, R. \& O'CONNELL, R. J. 2004. Prediction of Emperor-Hawaii seamount locations from a revised model of global plate motion and mantle flow. Nature, 430, 167.

STRAMMA, L., PETERSON, R. G. \& TOMCZAK, M. 1995. The south Pacific current. Journal of physical oceanography, 25, 77-91. 
STRATFORD, W. R., SUTHERLAND, R. \& COLLOT, J. 2018. Physical properties and seismic-reflection interpretation of bathyal marine sediments affected by carbonate and silica diagenesis in the Tasman Sea. New Zealand Journal of Geology and Geophysics, 61, 96-111.

STROGEN, D. P., BLAND, K. J., NICOL, A. \& KING, P. R. 2014. Paleogeography of the Taranaki Basin region during the latest Eocene-Early Miocene and implications for the 'total drowning' of Zealandia. New Zealand Journal of Geology and Geophysics, 57, 110-127.

STROGEN, D. P., SEEBECK, H., NICOL, A. \& KING, P. R. 2017. Two-phase Cretaceous-Paleocene rifting in the Taranaki Basin region, New Zealand; implications for Gondwana break-up. Journal of the Geological Society, 174, 929946.

STRUCKMEYER, H., YEUNG, M. \& BRADSHAW, M. Mesozoic palaeogeography of the northern margin of the Australian Plate and its implications for hydrocarbon exploration. 1990. Papua New Guinea (PNG) Petroleum Convention Proceedings.

SUDRE, J., MAES, C. \& GARÇON, V. 2013. On the global estimates of geostrophic and Ekman surface currents. Limnology and Oceanography: Fluids and Environments, 3, 1-20.

SUGGATE, R. 1990. Coal ranks in Permian-Lower Cretaceous rocks of New Zealand. New Zealand journal of geology and geophysics, 33, 163-172.

SUTHERLAND, R. 1995. The Australia-Pacific boundary and Cenozoic plate motions in the SW Pacific: Some constraints from Geosat data. Tectonics, 14, 819-831.

SUTHERLAND, R. 1999. Basement geology and tectonic development of the greater New Zealand region: an interpretation from regional magnetic data. Tectonophysics, 308, 341-362.

SUTHERLAND, R. 2019a. Expedition 371 methods.

SUTHERLAND, R. 2019b. Expedition 371 summary.

SUTHERLAND, R. 2019c. Site U1508.

SUTHERLAND, R., COLLOT, J., BACHE, F., HENRYS, S., BARKER, D., BROWNE, G., LAWRENCE, M., MORGANS, H., HOLLIS, C. \& CLOWES, C. 2017. Widespread compression associated with Eocene Tonga-Kermadec subduction initiation. Geology, 45, 355-358.

SUTHERLAND, R., COLLOT, J., HENRYS, S. A., BARKER, D. H. N., MUELLER, C., JUAN, C., , WOELZ, S., GERRING, P., QUINN, W., BOYES, A. F., COLLINS, K., O'BRIEN, G., POTAKA, G., WHITE, J., FERNANDEZ, J., SKORSTENGAARD, P. \& CAPPE-KERBART, C. 2014. TAN1409 voyage report : Tasman Frontier Geophysical Survey, RV Tangaroa, 19 July - 12 August 2014. GNS Science 2014/72, 65.

SUTHERLAND, R., COLlOT, J., LAFOY, Y., LOGAN, G. A., HACKNEY, R., STAGPOOLE, V., URUSKI, C., HASHIMOTO, T., HIGGINS, K. \& HERZER, R. H. 2010. Lithosphere delamination with foundering of lower crust and mantle caused permanent subsidence of New Caledonia Trough and transient uplift of Lord Howe Rise during Eocene and Oligocene initiation of Tonga-Kermadec subduction, western Pacific. Tectonics, 29.

SUTHERLAND, R., DICKENS, G. \& BLUM, P. 2018a. Expedition 371 Scientists. 2018. Expedition 371 Preliminary Report: Tasman Frontier Subduction Initiation and Paleogene Climate.

SUTHERLAND, R., DICKENS, G., BLUM, P., AGNINI, C., ALEGRET, L., ASATRYAN, G., BHATTACHARYA, J., BORDENAVE, A., CHANG, L. \& COLLOT, J. J. G. 2020. Continental-scale geographic change across Zealandia during Paleogene subduction initiation. 
SUTHERLAND, R., DICKENS, G. R., BLUM, P., AGNINI, C., ALEGRET, L., BHATTACHARYA, J., BORDENAVE, A., CHANG, L., COLLOT, J. \& CRAMWINCKEL, M. J. 2018b. Tasman frontier subduction initiation and paleogene climate. Integrated Ocean Drilling Program: Preliminary Reports, 144.

SUTHERLAND, R., VISKOVIC, P., BACHE, F., STAGPOOLE, V. M., COLLOT, J., ROUILLARD, P., HASHIMOTO, T., HACKNEY, R. I., HIGGINS, K. \& ROLLET, N. 2012. Compilation of seismic reflection data from the Tasman Frontier region, southwest Pacific, GNS Science.

SUTHERLAND R., DICKENS, G. R., BLUM, P. \& SCIENTISTS, A. T. E. 2019. Proceedings of the International Ocean Discovery Program. 371.

SUTTON, P. 2001. Detailed structure of the subtropical front over Chatham Rise, east of New Zealand. Journal of Geophysical Research: Oceans, 106, 31045-31056.

SYKES, R. 2001. Depositional and rank controls on the petroleum potential of coaly source rocks.

SYKES, R. \& SNOWDON, L. 2002. Guidelines for assessing the petroleum potential of coaly source rocks using Rock-Eval pyrolysis. Organic Geochemistry, 33, 14411455.

THORNTON, R., BURNS, B., KHURANA, A. \& RIGG, A. 1980. The Fortescue FieldNew Oil in the Gippsland Basin. The APPEA Journal, 20, 130-142.

TULLOCH, A., KIMBROUGH, D. \& WOOD, R. 1991. Carboniferous granite basement dredged from a site on the southwest margin of the Challenger Plateau, Tasman Sea. New Zealand Journal of Geology and Geophysics, 34, 121-126.

TUllOCH, A., RAMEZANI, J., MORTIMER, N., MORTENSEN, J., VAN DEN BOGAARD, P. \& MAAS, R. 2009. Cretaceous felsic volcanism in New Zealand and Lord Howe Rise (Zealandia) as a precursor to final Gondwana break-up. Geological Society, London, Special Publications, 321, 89-118.

TURNER, S., BEAN, L. B., DETTMANN, M., MCKELLAR, J. L., MCLOUGHLIN, S. \& THULBORN, T. 2009. Australian Jurassic sedimentary and fossil successions: current work and future prospects for marine and non-marine correlation. $G F F$, 131, 49-70.

URUSKI, C. \& BAILLIE, P. 2002. Petroleum Systems of the Deep Water Taranaki Basin, New Zealand.

URUSKI, C. \& BAILLIE, P. 2004. Mesozoic evolution of the Greater Taranaki Basin and implications for petroleum prospectivity. The APPEA Journal, 44, 385-396.

URUSKI, C., BAILLIE, P. \& STAGPOOLE, V. 2003. Development of the Taranaki Basin and comparisons with the Gippsland Basin: implications for deepwater exploration. The APPEA Journal, 43, 185-196.

URUSKI, C., BROWNE, G., STAGPOOLE, V., HERZER, R., BLAND, K., GRIFFIN, A., SYKES, R., RONCAGLIA, L., SCHIOLER, P. \& FUNNELL, R. 2008. Petroleum prospectivity of the Northland Basin, New Zealand. New Zealand Unpublished Openfile Petroleum Report, PR3933.

URUSKI, C., COOK, R., HERZER, R. \& ISAAC, M. 2004. Petroleum geology of the Northland sector of the greater Taranaki Basin.

URUSKI, C. \& WARBURTON, J. Sequence stratigraphy and facies prediction: PEP 38451, Deepwater Taranaki Basin. Proceedings of the 2010 New Zealand Petroleum Conference, Crown Minerals Unit, Wellington, 2010.

URUSKI, C. \& WOOD, R. 1991. A new look at the New Caledonia Basin, an extension of the Taranaki Basin, offshore North Island, New Zealand. Marine and petroleum geology, 8, 379-391.

URUSKI, C. L. 2008. Deepwater Taranaki, New Zealand: structural development and petroleum potential. Exploration geophysics, 39, 94-107. 
VAIL, P., MITCHUM JR, R. \& THOMPSON III, S. 1977. Seismic stratigraphy and global changes of sea level: Part 4. Global cycles of relative changes of sea level.: Section 2. Application of seismic reflection configuration to stratigraphic interpretation.

VAN ANDEL, T. H., HEATH, G. R. \& MOORE JR., T. C. 1975. Cenozoic history and paleoceanography of the central equatorial Pacific Ocean: a regional synthesis of Deep Sea Drilling project data. Geol. Soc. Am. Mem. 143, , 143.

VAN DER LINDEN, W. J. 1970. Morphology of the Tasman Sea floor. New Zealand Journal of Geology and Geophysics, 13, 282-291.

VOLK, H., GEORGE, S. C., MIDDLETON, H. \& SCHOFIELD, S. 2005. Geochemical comparison of fluid inclusion and present-day oil accumulations in the Papuan Foreland-evidence for previously unrecognised petroleum source rocks. Organic Geochemistry, 36, 29-51.

WAPLES, D. \& WULFF, K. Genetic classification and exploration significance of oils and seeps of the Papuan Basin. 1996. Papua New Guinea (PNG) Petroleum Convention Proceedings.

WEBB, D. J. 2000. Evidence for shallow zonal jets in the South Equatorial Current region of the southwest Pacific. Journal of Physical Oceanography, 30, 706-720.

WEISSEL, J. K. \& HAYES, D. E. 1977. Evolution of the Tasman Sea reappraised. Earth and planetary science letters, 36, 77-84.

WELLS, A. T. \& O'BRIEN, P. 1994. Geology and petroleum potential of the ClarenceMoreton basin, New South Wales and Queensland.

WHITEHOUSE, F. 1955. The Geology of the Queensland portion of the great Artesian Basin, Appendix G. Artesian water supplies in Queensland Department of the Coordinator General of Public Works, Queensland Parliamentary Papers, A561955.

WILLCOX, J. \& SAYERS, J. 2001. Gower Basin, Lord Howe Rise.

WILLCOX, J. \& SAYERS, J. 2002. Geological framework of the central Lord Howe Rise (Gower Basin) region. Geoscience Australia Record, 11, 156.

WILlCOX, J., SAYERS, J., STAGG, H. \& VAN DE BEUQUE, S. 2001. Geological framework of the Lord Howe Rise and adjacent ocean basins.

WOOD, R. \& WOODWARD, D. 2002. Sediment thickness and crustal structure of offshore western New Zealand from 3D gravity modelling. New Zealand Journal of Geology and Geophysics, 45, 243-255.

YANG, Y. \& APLIN, A. C. 2010. A permeability-porosity relationship for mudstones. Marine and Petroleum Geology, 27, 1692-1697.

ZACHOS, J. C., DICKENS, G. R. \& ZEEBE, R. E. 2008a. An early Cenozoic perspective on greenhouse warming and carbon-cycle dynamics. Nature, 451, 279.

ZACHOS, J. C., DICKENS, G. R. \& ZEEBE, R. E. 2008b. An early Cenozoic perspective on greenhouse warming and carbon-cycle dynamics. Nature, 451, 279-283. 


\section{Appendix A: New Zealand geological timescale}
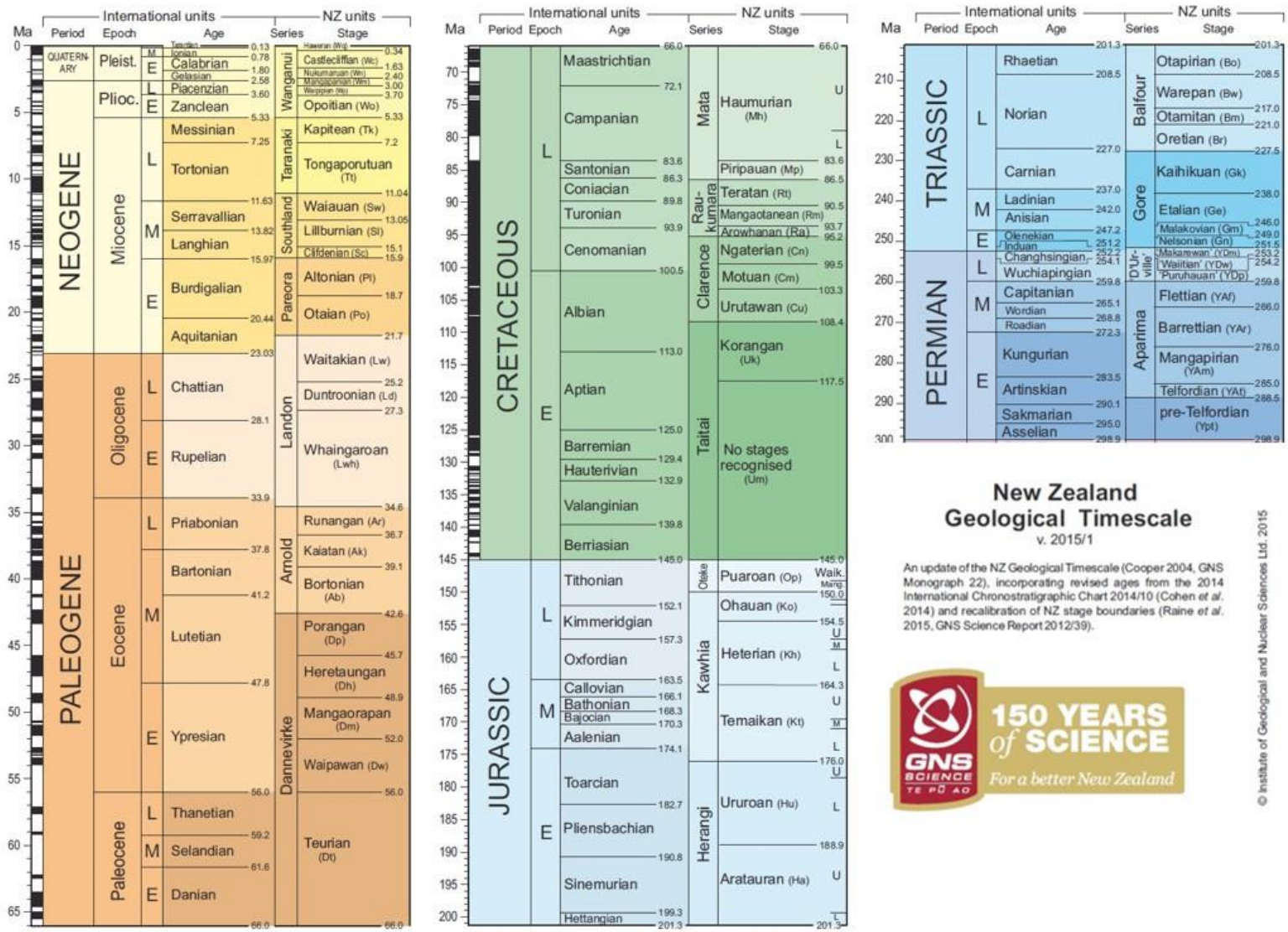

Figure A1. New Zealand geological timescale (Raine et al., 2012). 